\title{
Site U1403'
}

R.D. Norris, P.A. Wilson, P. Blum, A. Fehr, C. Agnini, A. Bornemann, S. Boulila, P.R. Bown, C. Cournede, O. Friedrich, A.K. Ghosh, C.J. Hollis, P.M. Hull, K. Jo, C.K. Junium, M. Kaneko, D. Liebrand, P.C. Lippert, Z. Liu, H. Matsui, K. Moriya, H. Nishi, B.N. Opdyke, D. Penman, B. Romans, H.D. Scher, P. Sexton, H. Takagi, S.K. Turner, J.H. Whiteside, T. Yamaguchi, and Y. Yamamoto ${ }^{2}$

\section{Chapter contents}

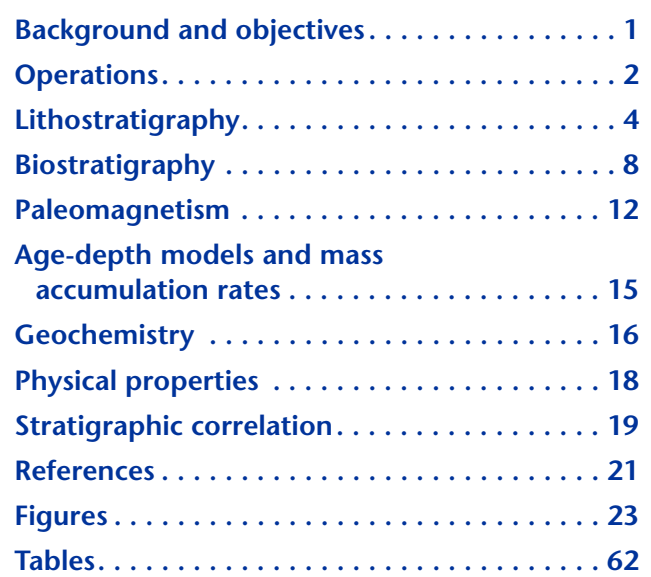

${ }^{1}$ Norris, R.D., Wilson, P.A., Blum, P., Fehr, A., Agnini, C., Bornemann, A., Boulila, S., Bown, P.R., Cournede, C., Friedrich, O., Ghosh, A.K., Hollis, C.J., Hull, P.M., Jo, K., Junium, C.K., Kaneko, M., Liebrand, D., Lippert, P.C., Liu, Z., Matsui, H., Moriya, K., Nishi, H., Opdyke, B.N., Penman, D., Romans, B., Scher, H.D., Sexton, P., Takagi, H., Turner, S.K., Whiteside, J.H., Yamaguchi, T., and Yamamoto, Y., 2014. Site U1403. In Norris, R.D., Wilson, P.A., Blum, P., and the Expedition 342 Scientists, Proc. IODP, 342: College Station, TX (Integrated Ocean Drilling Program). doi:10.2204/iodp.proc.342.104.2014

'Expedition 342 Scientists' addresses.

\section{Background and objectives}

Integrated Ocean Drilling Program (IODP) Site U1403 (proposed Site JA-01A; $39^{\circ} 56.60^{\prime} \mathrm{N}, 51^{\circ} 48.20^{\prime} \mathrm{W}, 4949 \mathrm{~m}$ water depth) (Fig. F1) is the deepest water site to be drilled on J-Anomaly Ridge and pins the deep end of the Paleogene Newfoundland sediment drifts depth transect. The site was positioned

- To capture deep excursions of the carbonate compensation depth (CCD) during the Paleogene and

- To help improve stratigraphic control on the sediment that was drilled at J-Anomaly Ridge (Figs. F2, F3).

Because Site U1403 is located at the toe of J-Anomaly Ridge, coring at this site will also capture

- A condensed sequence ( $150 \mathrm{~m}$ thick) through the prominent acoustically transparent package seen in our seismic data that is much more expanded upslope (>700 m thick) and

- The underlying seismic reflector-rich package (Figs. F2, F3).

Prior to drilling, we hypothesized these two packages were middle and upper Eocene drift deposits overlying a sequence of lower Eocene through Upper Cretaceous pelagic sediments. Given its current water depth of nearly $5 \mathrm{~km}$ and assuming a subsidence history for J-Anomaly Ridge akin to that reconstructed from Deep Sea Drilling Project (DSDP) Leg 43 results (Tucholke and Vogt, 1979) (see Fig. F2 in the "Expedition 342 summary" chapter [Norris et al., 2014a]), Site U1403 should be a sensitive recorder of CCD fluctuations, particularly during intervals when the CCD was depressed to abyssal depths. Of particular interest are CCDdeepening events associated with "overshoots" in carbonate ocean chemistry in the early recovery phases of the most extreme Cenozoic carbon cycle perturbations, such as the Eocene-Oligocene transition, the Paleocene/Eocene Thermal Maximum (PETM), and the Cretaceous/Paleogene (K/Pg) boundary (Figs. F2, F3). All three of these extreme events are thought to involve increased deep-sea carbonate burial flux involving a rebalancing of oceanic carbonate chemistry following major shocks to the Earth system (Dickens et al., 1997; Zachos et al., 2005; Merico et al., 2008). Site U1403 is positioned to capture a sedimentary expression of these carbonate overshoot events, which should be evident both through increased abundances of carbonate and improved carbonate microfossil preservation. Of particular interest 
at Site U1403 are early and middle Eocene "hyperthermals," the PETM, and the K/Pg boundary event.

Seismic stratigraphy (Figs. F2, F3) shows that the acoustically transparent sediment package thins considerably between modern water depths of 4800 and 4900 meters below sea level (mbsl), corresponding to paleodepths at $50 \mathrm{Ma}$ of $\sim 4600 \mathrm{mbsl}$. At the outset of Expedition 342, we hypothesized this thinning indicated the average position of the CCD during the middle and late Eocene.

We anticipated that the underlying $\sim 350 \mathrm{~m}$ thick reflector-rich package of lower Eocene and older sediment accumulated within or below the CCD. The nature of this sediment package is also of great interest for CCD reconstructions because the acoustic expression is of a sediment pile that expands in thickness with increasing water depth, exactly opposite from the overlying hypothesized middle and upper Eocene drift sequence.

Tucholke and Vogt (1979) reconstructed the North Atlantic CCD to be positioned at $\sim 3 \mathrm{~km}$ paleodepth during the Late Cretaceous, to undergo a temporary depression to below 5500 mbsl in the latest Cretaceous and early Paleocene, and to be located around 4400-4300 mbsl in the Eocene (see Fig. F2 in the "Expedition 342 summary" chapter [Norris et al., 2014a]). Compilation of carbonate records from North Atlantic DSDP sites, however, reveals that there is little constraint on the depth of the CCD in the Paleocene and Late Cretaceous North Atlantic Ocean. Sequences of Maastrichtian and Paleocene multicolored clay, presumably representing sub-CCD deposits, are present at $\sim 5000 \mathrm{mbsl}$ paleodepth at DSDP Site 386 near Bermuda and at DSDP Site 105 on the Hatteras Abyssal Plain. The upper possible depth range of the CCD in the Maastrichtian and early Paleocene is constrained by pelagic carbonates encountered at 3300 mbsl paleodepth at DSDP Site 384 (Tucholke and Vogt, 1979). Hence, prior to our expedition, the composition of the lower package at the toe of J-Anomaly Ridge at a paleodepth of 4000-4500 mbsl was extremely uncertain. Based on Paleogene CCD reconstructions for the equatorial Pacific (Lyle, Wilson, Janecek, et al., 2002; Pälike et al., 2012), it is quite possible that the sediment comprising the reflector-rich package at Site U1403 could have accumulated almost entirely below the CCD. Another hypothesis for Site U1403 is that the strong impedance contrasts seen in the upper $120 \mathrm{~m}$ of the lower sediment package corresponds to a sequence of alternating clays and cherts. Based on stratigraphic information from Site 384 and drilling results from Blake Nose (Norris, 2001), the particularly bright reflector at $\sim 150$ meters below seafloor (mbsf) was interpreted to be a prominent condensed and chert-rich interval of early/middle Eocene boundary age. In this interpretation, the PETM was anticipated at $230-240$ mbsf, associated with a change in reflector character, and the K/Pg boundary at 300 mbsf.

In addition to playing a key role in CCD reconstructions, Site U1403 was also needed to help understand the history of chemical stratification and ocean currents in the Paleogene North Atlantic Ocean. Most deep ocean drill sites are located at midocean depths ( 2000-2500 mbsl) when we account for thermal subsidence. Hence, Site U1403 is rare in that it was selected to recover a representative sequence deposited in true deep water $(\sim 4500 \mathrm{mbsl}$ in the Eocene). Furthermore, the site is well placed to record the history of deep waters formed in the far North Atlantic, or even the Arctic, because the western boundary current is constrained to flow directly over or around the Newfoundland ridges by geostrophic flow and the shape of the ocean basin. At the deep end of the J-Anomaly depth transect, the site should record the chemistry and flow history of abyssal waters in the Paleogene.

\section{Operations}

All times shown are local ship time (UTC $-2.5 \mathrm{~h}$ ). See Table T1 for coring summary.

\section{Hole U1403A summary}

Latitude: $39^{\circ} 56.5997^{\prime} \mathrm{N}$

Longitude: $51^{\circ} 48.1998^{\prime} \mathrm{W}$

Water depth (mbsl): 4944.3

Date started: 1708 h, 11 June 2012

Date finished: 1240 h, 14 June 2012

Time on hole (days): 2.8

Seafloor depth (m drilling depth below rig floor [DRF]): 4955.7

Seafloor depth estimation method: APC-calculated depth

Rig floor to sea level (m): 11.4

Penetration depth ( $\mathrm{m}$ drilling depth below seafloor [DSF]): 253.3

Cored interval $(\mathrm{m}): 253.3$

Recovered length (m): 231.82

Recovery (\%): 92

Total cores (number): 29

APC cores (number): 17

$\mathrm{XCB}$ cores (number): 12

Drilling system: 117/16 inch APC/XCB bit with $136.00 \mathrm{~m}$ BHA

Objective: Core from seafloor to $250 \mathrm{~m}$ DSF

Result: Target reached; objectives achieved 


\section{Hole U1403B summary}

Latitude: $39^{\circ} 56.5993^{\prime} \mathrm{N}$

Longitude: $51^{\circ} 48.1855^{\prime} \mathrm{W}$

Water depth (mbsl): 4948.7

Date started: 1240 h, 14 June 2012

Date finished: 1415 h, 19 June 2012

Time on hole (days): 5.1

Seafloor depth (m DRF): 4960.1

Seafloor depth estimation method: APC-calculated depth

Rig floor to sea level (m): 11.4

Penetration depth (m DSF): 265.1

Cored interval (m): 265.1

Recovered length (m): 229.81

Recovery (\%): 87

Total cores (number): 32

APC cores (number): 20

$\mathrm{XCB}$ cores (number): 12

Drilling system: 11\%16 inch APC/XCB bit with $136.00 \mathrm{~m}$ BHA

Objective: Core from seafloor to $250 \mathrm{~m}$ DSF

Result: Coring target reached; objectives achieved; logging attempt failed

\section{Description}

After a $946 \mathrm{nmi}$ transit from Site U1402 at a speed averaging $12.6 \mathrm{kt}$, the vessel arrived at Site U1403, the first site of the Paleogene Newfoundland sediment drifts project. The local vessel time was advanced $0.5 \mathrm{~h}$ during the transit, placing the vessel in the timezone for Newfoundland. The original plan for this site called for drilling three holes to a depth of $250 \mathrm{~m}$ DSF, but the science decision was ultimately to complete operations with two holes: Hole U1403A to $253.3 \mathrm{~m}$ DSF and Hole U1403B to 265.1 $m$ DSF. The decision was made to log Hole U1403B; however, the logging attempt failed because the tool became stuck and part of it broke off. Attempts to recover the tool also failed, resulting in loss of time.

\section{Hole U1403A coring}

The vessel stabilized over Site U1403 at 1708 h on 11 June 2012. The drill pipe was prepared and run to the seafloor. The precision depth recorder-calculated depth for the site was $4957.7 \mathrm{mbsl}$, and after some consideration, $4952 \mathrm{~m}$ drilling depth below rig floor (DRF) was selected as the shoot depth for the first core. Hole U1403A was spudded at $1020 \mathrm{~h}$ on 12 June. The mudline core recovered $5.85 \mathrm{~m}$ of sediment, and seafloor depth was established at 4955.7 m DRF (4944.3 mbsl). This seafloor depth was later suspected to be $\sim 4 \mathrm{~m}$ too high, based on the seafloor depth for Hole U1403B and correlative features found in Hole U1403B. The advanced piston corer
(APC) recovered Cores 342-U1403A-1H through $17 \mathrm{H}$, where a hard layer was encountered at $\sim 148 \mathrm{~m}$ DSF. Nonmagnetic core barrels were used for APC coring, and orientation was performed on all APC cores with the FlexIT tool. The extended core barrel (XCB) was deployed from Cores $18 \mathrm{X}$ through $29 \mathrm{X}$ to a final depth of $253.3 \mathrm{~m}$ DSF. The seafloor was cleared at $1240 \mathrm{~h}$ on 14 June, ending Hole U1403A. Overall core recovery for Hole U1403A was $231.82 \mathrm{~m}$ for the $253.3 \mathrm{~m}$ interval cored (92\% recovery).

\section{Hole U1403B coring}

The vessel was offset $20 \mathrm{~m}$ east, and Hole U1403B was spudded at $1730 \mathrm{~h}$ on 14 June. The $3.9 \mathrm{~m}$ long mudline core established seafloor depth at $4960.1 \mathrm{~m}$ DRF (4948.7 mbsl), which is $4.4 \mathrm{~m}$ deeper than recorded in Hole U1403A. This finding, along with other indicators, called into question the accuracy of the mudline core depth calculation in Hole U1403A. Cores $342-\mathrm{U} 1403 \mathrm{~B}-1 \mathrm{H}$ through $16 \mathrm{H}$ were recovered using nonmagnetic core barrels, and orientation was performed with the FlexIT tool. The chert layer identified in Hole U1403B was found to be exactly at the depth expected from Hole U1403A data, confirming the initial error in water depth for Hole U1403A. The XCB was deployed for Cores 17X through 18X, until we broke through the chert layers at $150.4 \mathrm{~m}$ DSF. The APC coring system was again deployed for Cores $19 \mathrm{H}$ through $22 \mathrm{H}$ to $175.9 \mathrm{~m}$ DSF. After a partial stroke core with a $2.97 \mathrm{~m}$ recovery, the $\mathrm{XCB}$ was again deployed for Cores $23 \mathrm{X}$ through $32 \mathrm{X}$ to a final depth of $265.1 \mathrm{~m}$ DSF. Overall, core recovery for Hole U1403B was $229.81 \mathrm{~m}$ for the $265.1 \mathrm{~m}$ cored interval (87\% recovery). At the conclusion of coring at $2200 \mathrm{~h}$ on 16 June, the hole was swept clean with 30 bbl of high-viscosity mud, and the drill string was pulled from the hole to $78.43 \mathrm{~m}$ DSF for logging with the triple combination (triple combo) and Formation MicroScanner-sonic tool strings.

At $2215 \mathrm{~h}$, the Schlumberger Engineer began rigging up the logging equipment. The first logging run reached the bottom-hole assembly (BHA) but was unable to exit the BHA. The tools were returned to surface and examined to determine cause, and after making some corrections to the wireline tools, they were again deployed at $0710 \mathrm{~h}$ on 17 June. The tool string was run back to the BHA and again failed to pass through. This time the tools became firmly stuck inside the BHA with $\sim 17 \mathrm{~m}$ of the tool string extending out from the bit. After working the tools for several hours with no progress, the Kinley crimp was set on the wireline above the tool to prevent the tool from falling out, and the logging line was severed at $1830 \mathrm{~h}$ on 17 June using the Kinley cutter. The wireline was retrieved and spooled back onto 
the winch drum. The drill string was pulled from the hole with a carefully calculated space out, which should have resulted in the bottom of the Schlumberger tool string being at least $5 \mathrm{~m}$ above seafloor when the pipe was set down on the dual elevator stool. At $0630 \mathrm{~h}$ on 18 June, with $117 \mathrm{~m}$ of the BHA remaining below the rig floor, the end of the Schlumberger wireline was found. The tool string was freed from the BHA and rigged down on the drill floor. It was discovered that the triple combo tool string had parted at the lower (MC) centralizer. This left $\sim 17 \mathrm{~m}$ of tools missing from the bottom of the tool string, including the nuclear sources for the density and porosity tools. When the bit cleared the rig floor, inspection revealed manganese nodules lodged between the roller bit cones, along with other typical seafloor sediments. Manganese nodules and surface sediments were also found in the broken end of the MC centralizer on the triple combo. A close examination of the tool failure supports the speculation that when the BHA cleared the rig floor, the high bottom current that we had been experiencing since first coming onto site had caused the BHA to shift with the current while the logging tool string remained in the hole.

At this point all parties involved contacted their respective shore counterparts and informed them of the loss of the nuclear sources. Shipboard personnel outlined the limited actions that could be taken toward identifying the location and condition of the sources. The plan included a seafloor camera survey using a $100 \mathrm{~m} \times 100 \mathrm{~m}$ search grid centered over Hole U1403B. While the drill string was being tripped toward the seafloor, the subsea camera system and vibration isolation transport (VIT) were readied for deployment. A grapple was attached to the underside of the camera frame, which would have been able to grab the "fish" while the winch, in combination with the drill string, was used to lift the tools toward the surface. The VIT frame is designed not to slide over the bit on the end of the drill string.

After tripping the drill string to $3499 \mathrm{~m}$ DRF, the rig was secured at $1645 \mathrm{~h}$ on 18 June. Installation of the VIT system around the drill pipe in the moonpool, which routinely takes $30 \mathrm{~min}$, proved complicated because of the ocean current pushing the pipe all the way to the side of the lower guide horn, which could therefore not be opened. The ship was eventually powered up, and using a combination of drift and powering down current, we were able to centralize the drill pipe in the moonpool, which allowed us to open the doors. After the VIT was deployed to $100 \mathrm{~m}$ DRF, the doors were closed and the upper guide horn was replaced. It took almost $2.5 \mathrm{~h}$ to accomplish this task. The camera was run to the bottom while the drill string was tripped to bottom. During the entire camera run, the camera was shaking, vibrating, and rotating around the pipe at different depths. At 2145 $\mathrm{h}$, with the bit $\sim 30 \mathrm{~m}$ from seafloor, the signal from the subsea camera was lost. The Mesotech sonar, which is also mounted on the VIT frame, failed as well. While pulling the camera to surface, the winch operator noticed that the effort required to pull the camera frame up was much less than normal for the water depth. Our suspicion that the coaxial cable supporting the camera system had failed was confirmed when the camera cable arrived at the rig floor.

At that point there was no option other than to pull the drill string from just above the seafloor and to recover the VIT frame with subsea camera and sonar. Preliminary estimates for the time to repair the camera system were $24-48 \mathrm{~h}$. Siem Offshore and IODP personnel determined that another attempt at a survey, if the camera could be repaired, would very likely result in another failure of the VIT subsea camera system. The impact of the ocean currents on the VIT frame resulted in two failures of the camera and sonar during the first deployment and nearly resulted in the loss of the only reentry system that IODP has available to continue the program. Further attempts could have resulted in the complete loss of our mission-critical reentry system.

The decision not to deploy the camera system again at this site also meant that we were unable to locate the lost logging tool or Hole U1403B, which compromised our ability to follow the abandonment guidelines of an irretrievable well-logging source given to us by the onsite Schlumberger engineer. The requirement to immobilize and seal the sources into place with a cement plug was impossible to accomplish because it was impossible to find either the tool string or the hole. The drill string with the damaged VIT was recovered at $\sim 1400 \mathrm{~h}$ on 19 June. A total of 2.7 days was spent for the attempt to log. The drill floor was secured at 1415 h, ending Site U1403 and Hole U1403B. The vessel then proceeded under way to Site U1404.

\section{Lithostratigraphy}

The downhole sedimentary progression recovered from Holes U1403A and U1403B reveals a diversity of deep-sea pelagic sediment of Pleistocene to Late Cretaceous (Campanian) age, comprising five lithostratigraphic units (Figs. F4, F5, F6, F7; Table T2).

Lithostratigraphic Unit I is a $3 \mathrm{~m}$ thick nannofossil ooze with clay and foraminiferal sand of Pleistocene age. Underlying Unit I is Unit II, which comprises 
$\sim 70 \mathrm{~m}$ of fine-grained siliciclastics composed of clay and clay with silt. Unit II contains no diagnostic microfossil datums but has a preliminary middle to late Eocene age on the basis of magnetostratigraphy for 72.63-46.08 mbsf in Hole U1403A. Unit III is radiolarian clay of Eocene age. Unit IV is defined at the top by the occurrence of relatively carbonate rich sediments and at the base by the first downhole occurrence of chert. The sediment of Unit IV is predominantly nannofossil ooze with clay and radiolarians and clay with radiolarians and is of middle Eocene age. Unit V comprises nannofossil chalk with variable amounts of planktonic foraminifers and clay and interbedded, poorly recovered chert. Unit $\mathrm{V}$ is divided into two subunits, $\mathrm{Va}$ and $\mathrm{Vb}$, based on the transition to high carbonate-content chalks below the $\mathrm{K} / \mathrm{Pg}$ boundary.

Lithostratigraphic units and boundaries are defined by changes in lithology (as identified by visual core description and smear slide observations), physical properties, color reflectance $\left(\mathrm{L}^{*}, \mathrm{a}^{*}\right.$, and $\left.\mathrm{b}^{*}\right)$, and biogenic content (calcium carbonate and silica). The lithologic differences observed between units are primarily attributable to varying amounts of nannofossils, diatoms, radiolarians, and foraminifers (Fig. F7). Lithologic descriptions are based on sediment recovered from Hole U1403A and supplemented with observations from Hole U1403B.

\section{Unit I}

Intervals: $342-\mathrm{U} 1403 \mathrm{~A}-1 \mathrm{H}-1,0 \mathrm{~cm}$, to $1 \mathrm{H}-2,150$ $\mathrm{cm}$; 342-U1403B-1H-1, $0 \mathrm{~cm}$, to $1 \mathrm{H}-2,150 \mathrm{~cm}$

Depths: Hole U1403A = 0-3.0 mbsf; Hole U1403B $=0-3.0 \mathrm{mbsf}$

Age: Pleistocene

Lithology: clay with nannofossils

The main lithology of Unit I is brown (10YR 5/3 and 7.5YR 4/3) clay with varying abundances of nannofossils, foraminifers, and silt-sized quartz, allowing for the identification of various individual beds of foraminiferal clay, nannofossil clay with foraminifers, and nannofossil ooze with clay and/or foraminifers (Figs. F4, F5, F6). Foraminiferal sand occurs in a discrete $1 \mathrm{~cm}$ thick layer at interval 342-U1403A-1H$1,45 \mathrm{~cm}$. Carbonate content changes (from 0 to 34.6 $\mathrm{wt} \%$ ) are principally driven by the abundance of calcareous nannofossils (Figs. F4, F7). Manganese nodules ranging from millimeter to centimeter scales are found throughout (Fig. F8). One notable nodule at interval 342-U1403A-1H-1, $105 \mathrm{~cm}$, was dragged through the core during splitting, causing significant disturbance. A semirounded, $3 \mathrm{~cm}$ diameter, black aphanitic cobble, likely a basalt dropstone, was found at interval 342-U1403A-1H-1, $3 \mathrm{~cm}$. Bioturbation is heavy to complete throughout Unit I with no discrete layers or burrows visible. Magnetic susceptibility is higher in Unit I than in most of Unit II. However, the downhole transition in magnetic susceptibility between these two units takes place much more gradually than the lithologically defined unit boundary, which is defined by the absence of calcareous nannofossils and measurable calcium carbonate.

\section{Unit II}

Intervals: $342-\mathrm{U} 1403 \mathrm{~A}-1 \mathrm{H}-3,0 \mathrm{~cm}$, through $8 \mathrm{H}-$ CC, $43 \mathrm{~cm}$; 342-U1403B-1H-3, $0 \mathrm{~cm}$, through 9H-5, $124 \mathrm{~cm}$

Depths: Hole U1403A $=3.0-72.30$ mbsf; Hole $\mathrm{U} 1403 \mathrm{~B}=3.0-70.64 \mathrm{mbsf}$

Age: middle Eocene

Lithology: clay

The major lithology of Unit II is brown (10YR 6/2 to 7.5 YR $4 / 3$ to 5 YR 5/4) to light gray (10YR 7/2) clay. The clay contains quartz and zeolites as minor lithologic components (Figs. F4, F5, F6, F7). Color variations in this unit are largely due to the variable distribution of disseminated Mn oxides and discrete Mn oxide layers. Large (up to $10 \mathrm{~cm}$ in diameter) $\mathrm{Mn}$ nodules are present at the mudline. Sediment is usually heavily bioturbated or is fully homogenized. Rare occurrences of radiolarians and distinctive pink (2.5Y 7/3) nodules or concretions are increasingly common toward the bottom of the unit, the latter of which are found as discrete blebs $1-3 \mathrm{~cm}$ in diameter or in crude layers. In general, magnetic susceptibility in Unit II is low compared to Unit I. The contact between Units II and III is clearly defined by the first downhole occurrence of abundant, well-preserved radiolarians.

Shipboard X-ray diffraction (XRD) analyses revealed that the sediment of Unit II is homogeneous with illite, montmorillonite, illite/montmorillonite mixedlayer clay minerals, and quartz as the main components. Minor lithologic components include plagioclase, kaolinite, and chlorite.

\section{Unit III}

Intervals: $342-\mathrm{U} 1403 \mathrm{~A}-9 \mathrm{H}-1,0 \mathrm{~cm}$, through $12 \mathrm{H}-$ CC, $34 \mathrm{~cm}$; 342-U1403B-9H-5, $124 \mathrm{~cm}$, through $14 \mathrm{H}-\mathrm{CC}, 23 \mathrm{~cm}$

Depths: Hole U1403A = 72.30-119.14 mbsf; Hole $\mathrm{U} 1403 \mathrm{~B}=70.64-120.40 \mathrm{mbsf}$

Age: middle Eocene

Lithology: radiolarian clay

Unit III is light brown (10Y 5/2) to pinkish gray (7.5Y $6 / 4$ ) mottled to homogeneous radiolarian clay transitioning to greenish gray (10Y 6/1) and brownish gray $(2.5 \mathrm{Y} 6 / 2)$ radiolarian clay in the lowermost $20 \mathrm{~m}$ 
(Figs. F4, F5, F6, F7). Smear slide analyses reveal wellpreserved radiolarians, sponge spicules, diatoms, and silicoflagellates (in order of descending abundance) (Fig. F6). Bioturbation is moderate to complete, resulting in a mottled to homogeneous sedimentary fabric, respectively.

Minor lithologic constituents include unusual pink ( 2.5 Y $7 / 3$ to 2.5 YR $6 / 4$ ) nodules that occur throughout this unit in variable abundance. These nodules occur as $1-2 \mathrm{~cm}$ thick blebs or in thin $(1 \mathrm{~cm})$, distinct layers and are slightly harder than their host sediment. XRD analyses revealed that these nodules consist of an authigenically formed pink montmorillonite (Fig. F9) with minor quantities of carbonate minerals. In Core 342-U1403A-11H, small manganese nodules $(<1 \mathrm{~cm}$ in diameter) with green halos also occur occasionally.

\section{Unit IV}

Intervals: 342-U1403A-13H-7, $0 \mathrm{~cm}$, through $17 \mathrm{H}-$ CC, $23 \mathrm{~cm}$; 342-U1403B-14H-CC, $23 \mathrm{~cm}$, through $17 \mathrm{X}-1,88 \mathrm{~cm}$

Depths: Hole U1403A = 119.14-147.80 mbsf; Hole $\mathrm{U} 1403 \mathrm{~B}=120.40-145.40 \mathrm{mbsf}$

Age: early Eocene

Lithology: nannofossil ooze with clay and radiolarians

Unit IV is a $\sim 26 \mathrm{~m}$ thick nannofossil ooze with clay and radiolarians. Sediment color varies at the decimeter scale, alternating between pale green (10Y 7/2) and greenish gray $(5 G Y$ 6/1) and between pale brown (10YR 6/3) and reddish brown (5YR 5/3) (Figs. F4, F5, F6). Reddish brown horizons in the lower part of this unit are radiolarian-dominated oozes and contain fewer calcareous nannofossils than the other sediment of Unit IV.

Carbonate content (up to $70 \mathrm{wt} \%$ ) is principally contributed by calcareous nannofossils (Figs. F4, F7). Sediment is heavily bioturbated through most of the unit, and a pinkish color (5YR 7/4) characterizes the lowermost $7.6 \mathrm{~m}$ of Unit IV. The downhole increase in carbonate content is paralleled by a major increase in $\mathrm{a}^{*}$ and $\mathrm{b}^{*}$ color data and a distinctive minimum in dry bulk density, declining from $\sim 1.5$ to 1.2 $\mathrm{g} / \mathrm{cm}^{3}$. Magnetic susceptibility remains low but increases slightly (from $\sim 15$ to $35 \mathrm{IU}$ ) from the top to the bottom of the unit.

This unit is clearly defined by the presence of biogenic carbonate at its top and by a prominent chert layer at its bottom. The contact with Unit V, as defined by the chert layer, was recovered in Core 342U1403A-17H. This chert tentatively represents the major seismic reflector at $\sim 145$ mbsf identified in site survey seismics.

\section{Unit V}

Intervals: $342-\mathrm{U} 1403 \mathrm{~A}-18 \mathrm{X}-1,0 \mathrm{~cm}$, through $28 \mathrm{X}-$ CC, $29 \mathrm{~cm}$; 342-U1403B-18X-1, $0 \mathrm{~cm}$, through $32 \mathrm{X}-\mathrm{CC}, 12 \mathrm{~cm}$

Depths: Hole U1403A = 147.80-242.30 mbsf; Hole $\mathrm{U} 1403 \mathrm{~B}=145.40-261.76 \mathrm{mbsf}$

Age: early Eocene to Campanian

Lithologies: nannofossil ooze with clay, clay, nannofossil chalk with clay and nannofossil chalk; minor lithologies include radiolarian clay, clay with nannofossils, and cherts.

Unit $\mathrm{V}$ and its two subunits comprise a mixed sedimentary package of nannofossil chalk with clay, clay, and interbedded cherts. The top of the unit is defined by the first occurrence of chert (Fig. F4). Notably, sediment in this unit also contains the first downhole occurrence of planktonic foraminifers after those observed in Unit I. Prominent hyperthermal events (PETM and Eocene Thermal Maximum 2 [ETM2]) are lithologically well expressed in Unit V, displaying local maxima in magnetic susceptibility. A well-preserved $\mathrm{K} / \mathrm{Pg}$ boundary ejecta layer and a Campanian-Maastrichtian sequence were also recovered.

\section{Subunit Va}

Intervals: 342-U1403A-18X-1, $0 \mathrm{~cm}$, through 26X$5,12 \mathrm{~cm} ; 342-\mathrm{U} 1403 \mathrm{~B}-18 \mathrm{X}-1,0 \mathrm{~cm}$, through 28X-1, $46.5 \mathrm{~cm}$

Depths: Hole U1403A = 147.80-220.62 mbsf; Hole $\mathrm{U} 1403 \mathrm{~B}=145.40-217.07 \mathrm{mbsf}$

Age: early Eocene to Paleocene

Lithology: nannofossil ooze with clay; minor lithologies include clay and chert

Subunit Va comprises an Eocene through Paleocene sequence of brown (7.5YR 5/4 to 7.5YR 7/3) and pale green $(10 Y 7 / 2)$ to light greenish gray (10Y 6/1) nannofossil ooze with clay, with minor very dark grayish brown (10YR 3/2) chert in the Eocene sequence (Figs. F4, F5, F6, F7). Subunit Va is defined at its top by the first downhole occurrence of a chert layer (see "Unit IV"). The contact between Subunits $\mathrm{Va}$ and $\mathrm{Vb}$ is defined by the K/Pg boundary. Downhole of the Subunit $\mathrm{Va} / \mathrm{Vb}$ contact is the first occurrence of very carbonate rich chalk ( $>70 \mathrm{wt} \%$ carbonate).

Prominent reddish brown (5YR 5/3-4) and very dark gray (5YR 3/1-2) clay layers are associated with the PETM (discussed below). The Paleocene interval of this subunit is composed of light brownish gray (10YR 6/2) nannofossil ooze and dark yellowish brown (10YR 4/4) clay devoid of carbonate. The K/Pg interval was recovered in both Holes U1403A (interval 342-U1403A-26X-5, $10 \mathrm{~cm} ; 220.60 \mathrm{mbsf}$ ) and U1403B (342-U1403B-28X-1, $47 \mathrm{~cm} ; 217.07 \mathrm{mbsf})$. 
The $2.5 \mathrm{~cm}$ thick event bed is characterized by greenish black (5G 2.5/1) sandy mud (2.5 cm thick) with normally graded green sand-sized spherules (Figs. F10, F11).

Minor lithologies include very dark grayish brown (10YR 3/2) cherts and biosiliceous indurated sediment (porcellanites) with very well preserved Planolites burrows associated with intervals of poor core recovery (Fig. F5E). Carbonate content ranges between 0 and $50 \mathrm{wt} \%$. Magnetic susceptibility and reflectance data display several distinctive maxima and minima for this subunit partly related to well-described changes in magnetic susceptibility through the ETM2 and PETM (Figs. F12, F13). Bioturbation intensity ranges from complete to slight, with minima occurring during the hyperthermal intervals. Rhythmic color variations typically at the decimeter scale between light brownish gray (10YR 6/2) and dark yellowish brown (10YR 4/4) occur during several intervals of the lower part of Subunit Va and are superimposed over primary color changes.

\section{Subunit Vb}

Intervals: $342-\mathrm{U} 1403 \mathrm{~A}-26 \mathrm{X}-5,12 \mathrm{~cm}$, through 28X-CC, $29 \mathrm{~cm}$; 342-U1403B-28X-1, $46.5 \mathrm{~cm}$, through 32X-CC, $12 \mathrm{~cm}$

Depths: Hole U1403A = 220.62-242.30 mbsf; Hole $\mathrm{U} 1403 \mathrm{~B}=217.07-261.76 \mathrm{mbsf}$

Age: Maastrichtian to Campanian

Lithology: nannofossil chalk with foraminifers and clay

The first downhole occurrence of Cretaceous-aged sediment is pale yellow $(2.5 \mathrm{Y} 7 / 3)$ to very pale brown (10YR 7/2) nannofossil chalk (Figs. F4, F7, F10). This sediment is characteristic of the ooze-chalk transition; it deforms slightly under pressure but typically fractures. Subtle decimeter-scale rhythmic color variations between pale yellow $(2.5 \mathrm{Y} 7 / 3)$ to very pale brown (10YR 7/2) are present throughout Subunit Vb. Sediment color changes episodically to dark gray (10YR 4/1) nannofossil chalk with clay. Bioturbation is well developed in this sediment, with Planolites and Chondrites as the dominant ichnofacies. Centimeter-scale manganese nodules are also present. Calcium carbonate content ranges from 35 to $80 \mathrm{wt} \%$.

Subunit $\mathrm{Vb}$ is the only interval at Site U1403 in which planktonic foraminifers occur consistently in higher abundances than in pre-Pleistocene-age sediments. This microfossil group contributes substantially to the calcium carbonate content of the sediment. Calcium carbonate content in this subunit is the highest seen at Site U1403, consistent with observed high dry bulk density values (Fig. F4). The thickness of this subunit varies between the two holes because of the deeper subbottom depths attained in Hole U1403B.

\section{Lithostratigraphic unit summary}

At Site U1403, the uppermost $2 \mathrm{~m}$ of the sedimentary sequence is Pleistocene nannofossil ooze with clay, foraminifers, and radiolarians (Unit I). These sediments are underlain by a $69 \mathrm{~m}$ thick sequence of clay with silt and manganese nodules, barren of any siliceous or calcareous microfossils (Unit II). The upper half of this unit remains undated at the time of this report, whereas the lower half is dated as middle to late Eocene on the basis of magnetostratigraphy (see "Paleomagnetism"). Unit III comprises $38 \mathrm{~m}$ of middle Eocene radiolarian ooze with clay, and Unit IV is $28 \mathrm{~m}$ of Eocene nannofossil ooze with interbedded clay layers. The lowermost $95 \mathrm{~m}$ (Unit V) at Site U1403 is composed of nannofossil ooze, chalk, and clay with interbedded cherts. The occurrence of cherts necessitated XCB coring and resulted in poor recovery compared to the overlying units.

The low and variable carbonate content at Site U1403 suggests that the site was close to the CCD for much of its Cenozoic history, and incursions of carbonate reflect the local history of the CCD. Notably, calcium carbonate content increases $4 \mathrm{~m}$ above the Paleocene/Eocene boundary (as identified by biostratigraphy and magnetic susceptibility), which may be evidence of a carbonate compensation overshoot, or deepening of the CCD (Dickens et al., 1997), during the recovery interval of the PETM. A similar increase in carbonate content occurs above the ETM2, suggesting that this site was situated at an ideal depth to capture the magnitude and duration of such CCD fluctuations (Fig. F4).

The majority of the Paleocene is carbonate poor, suggesting a paleodepth below the local CCD. By contrast, sediments below the K/Pg boundary are predominantly calcareous chalks, suggesting that Site U1403 was at or above the CCD during Late Cretaceous time.

\section{Possible record of the late Eocene Chesapeake Bay impact event}

In Cores 342-U1403A-6H and 342-U1403B-6H, we observed prominent, $30 \mathrm{~cm}$ thick, bluish green (5G $6 / 1$ ) clay layers that are associated with a significant excursion in magnetic susceptibility to low values and local maxima in natural gamma radiation (NGR) (Fig. F14). Smear slides reveal euhedral feldspar crystals, suggesting that this bed may represent a volcanic ash layer. Alternatively, paleomagnetic data sug- 
gest a late Eocene age consistent with the timing of the late Eocene Chesapeake Bay bolide impact event.

\section{Paleocene/Eocene Thermal Maximum and Eocene Thermal Maximum 2}

Magnetic susceptibility at Site U1403 in the interval spanning the early Cenozoic hyperthermal events (the PETM at $\sim 55.9 \mathrm{Ma}$ and ETM2 at $\sim 54.1 \mathrm{Ma}$ ) shows relatively high amplitude variations (Fig. F12). High-frequency magnetic susceptibility oscillations display a cyclic pattern, with a prominent longwavelength magnetic susceptibility cycle occurring at $\sim 20$ mbsf, bounding the two events. Both the ETM2 and PETM show higher magnetic susceptibility values, whereas magnetic susceptibility variations within the interval (163-173 mbsf) are smaller in amplitude ( 20 IU). Sediment is greenish gray (10Y 7/1) in this interval (Fig. F12), possibly indicating anoxic sedimentary conditions and thus fewer ferrimagnetic minerals incorporated in the sediment. Magnetic susceptibility shows no correspondence with carbonate content. The onset of the PETM is placed at the base of Core 342-U1403A-21X, which corresponds to the first occurrence of PETM-excursion radiolarians (Figs. F12, F13).

\section{Cretaceous/Paleogene boundary event}

A K/Pg boundary section was identified at Site U1403 on the basis of lithostratigraphic and biostratigraphic observations (see "Biostratigraphy"). A normally graded spherule-rich ejecta bed was recovered in both holes drilled at this site (Figs. F10, F11). The base of the spherule layer occurs at intervals 342U1403A-26X-5, $12 \mathrm{~cm}$ (220.62 mbsf), and 342U1403B-28X-1, $46.5 \mathrm{~cm}$ (217.07 mbsf). Both boundary sections display the same general lithostratigraphic sequence, including from bottom to top:

1. Moderately bioturbated splotchy pink and white-gray latest Cretaceous chalks with abundant, diverse Late Cretaceous nannoplankton assemblages;

2. A very lightly bioturbated white-gray layer, $\sim 0.5$ $\mathrm{cm}$ thick, with a sharp basal contact immediately below;

3. A $\sim 0.5 \mathrm{~cm}$ thick bed of green sand- to silt-sized impact spherules overlain by a $\sim 0.5 \mathrm{~cm}$ thick bed of light greenish gray chalk with abundant calcispheres and early Paleocene biostratigraphic markers; and

4. A distinctly bioturbated pink (5YR 7/4) bed topped by light brown (7.5YR 6/3) chalk containing early Danian planktonic foraminifers and nannoplankton.
The K/Pg boundary in Hole U1403B appears less disturbed by drilling than in Hole U1403A, as evidenced by the presentation of distinct brown-tan color cycles in the upper Maastrichtian and relatively little deformation of the spherule bed in Hole U1403B and an undisturbed fine white-gray layer underlying the impact spherules and less fracturing of $\mathrm{K} / \mathrm{Pg}$ boundary clays.

\section{Biostratigraphy}

Coring at Site U1403 recovered a $265 \mathrm{~m}$ thick sequence of Quaternary-upper Campanian clay, radiolarian clay, and nannofossil ooze with minor chert layers. Clay and radiolarian clay are the dominant lithologies in the upper $119 \mathrm{mbsf}$, but nannofossils and planktonic foraminifers are present in the uppermost two sections of Hole U1403A (0.00-2.21 mbsf). Lithostratigraphic Units IV and V, below 119.14 mbsf, are predominantly composed of nannofossil ooze with clay-rich layers that are sometimes noncalcareous. Nannofossils and planktonic foraminifers indicate that the uppermost $2 \mathrm{~m}$ is Quaternary in age (Zones NN19-NN20 and Pt1). Rare to common spumellarian radiolarians are present in the upper $67 \mathrm{~m}$, but they are poorly preserved and not age diagnostic. We were therefore unable to provide definitive ages for 2.20-66.91 mbsf in Hole U1403A. Below 66.91 mbsf, first radiolarians and then radiolarians and nannofossils provide biostratigraphic control, indicating middle Eocene to late Campanian-aged sediment.

An integrated calcareous and siliceous microfossil biozonation is shown in Figure F15. Nannofossil datum and zonal determinations agree well with the radiolarian biostratigraphy. An age-depth plot including biostratigraphic and paleomagnetic datums is shown in Figure F16.

Radiolarians are well preserved in the Eocene sediment recovered at Site U1403 and provide a coherent high-resolution biochronology. Calcareous nannofossils are abundant and poorly to well preserved when present. Planktonic foraminifers are absent through much of the sequence but occur in several samples in the lower Eocene, lower Paleocene, and Upper Cretaceous nannofossil ooze lithologies. Benthic foraminifers are present in the lower Eocene to lower Paleocene sediment and are abundant in Campanian to Maastrichtian sediment at Site U1403. In general, these benthic foraminifers indicate lower bathyal to abyssal paleodepths. A summary of calcareous and siliceous microfossil abundance and preservation is given in Figure F17. 


\section{Calcareous nannofossils}

Calcareous nannofossil biostratigraphy is based on analysis of core catcher samples from both holes and from additional working-half section samples from Hole U1403A for the Paleogene and Hole U1403B for the Cretaceous. Depth positions and age estimates of biostratigraphic marker events are shown in Table T3. Calcareous nannofossil occurrence data are shown in Table T4. Note that the distribution chart is based on shipboard study only and is, therefore, biased toward age-diagnostic species.

At Site U1403, the preservation of calcareous nannofossils varies from poor to good. Dissolved assemblages characterize the uppermost lower Eocene sediment, whereas Cretaceous and Paleocene calcareous nannofossils show moderate to good preservation (Fig. F17).

The uppermost interval, from Samples 342-U1403A$1 \mathrm{H}-1,45 \mathrm{~cm}$, to $1 \mathrm{H}-2,70 \mathrm{~cm}(0.45-2.2 \mathrm{mbsf})$, contains abundant nannofossils indicative of upper Quaternary Zones NN21/20-NN18. From Samples $1 \mathrm{H}-3,70 \mathrm{~cm}$, to $13 \mathrm{H}-6,25 \mathrm{~cm}(3.7-117.93 \mathrm{mbsf})$, the sediment is noncalcareous and barren of nannofossils.

The interval from Samples 342-U1403A-13H-6, 100 $\mathrm{cm}$, to $21 \mathrm{X}-5,28 \mathrm{~cm}(118.68-181.68 \mathrm{mbsf})$, is largely nannofossiliferous. Nannofossil Zone NP14 is recognized using the base of Discoaster sublodoensis in Sample 15H-4, $75 \mathrm{~cm}$ (134.55 mbsf). The base of Nannotetrina cristata in Sample 15H-1, 39 cm (129.69 mbsf), is used to informally divide Zone NP14 because Blackites inflatus, which approximates the lower/middle Eocene boundary, is not present at Site U1403. The top of Tribrachiatus orthostylus in Sample 342-U1403A-17H-CC (147.8 mbsf), base of Discoaster lodoensis in Sample 18X-CC (148.76 mbsf), top of Tribrachiatus contortus in Sample 19X-4, 38 cm (160.88 mbsf), and base of Tribrachiatus bramlettei in Sample 21X-2, $28 \mathrm{~cm}$ (177.18 mbsf), delineate lower Eocene Zones NP13-NP10. The additional biohorizons of the base of Discoaster diastypus, base of T. contortus, and base of $T$. orthostylus provide further support for the identification of Zone NP10. The base of the Rhomboaster spp. biohorizon, which occurs in Sample 342-U1403A-21X-5W, $28 \mathrm{~cm}$ (181.68 mbsf), is close to, or coincident with, the base of the Eocene and is also used by some authors to mark the base of Subzone NP9b. Within Subzone NP9b we also observed the top of Fasciculithus spp., which is found to occur 300 k.y. after the Paleocene/Eocene boundary (e.g., Raffi et al., 2005). The presence of Discoaster araneus, just above the base Rhomboaster datum level, indicates the presence of PETM-equivalent sediment. Below the base Rhomboaster spp. level, in the interval from Samples 342-U1403A-21X-5, $83 \mathrm{~cm}$, to 22X-CC (182.23-188.66 mbsf), the sediment is red clay and barren of calcareous nannofossils.

Calcareous nannofossils reappear from Sample 342U1403A-23X-4, $139 \mathrm{~cm}$ (200.59 mbsf), and indicate a late Danian age (Zone NP4) based on the presence of Fasciculithus magnus (Sample 25X-1, $115 \mathrm{~cm} ; 210.85$ mbsf) and absence of Fasciculithus tympaniformis. The base of Chiasmolithus danicus in Sample 26X-1, 20 $\mathrm{cm}$ (214.7 mbsf), the base of Cruciplacolithus intermedius in Sample 26X-3, $84 \mathrm{~cm}$ (218.34 mbsf), and coincident bases of Biantholithus sparsus and the calcisphere acme in Sample 26X-5, $9 \mathrm{~cm}$ (220.59 mbsf), delineate the lower Danian Zones NP3-NP1 and the Cretaceous/Paleogene boundary. The Zone NP2 assemblage is characterized by abundant Prinsius tenuiculus and the base of Coccolithus pelagicus. Immediately above the K/Pg boundary (Samples 342U1403A-26X-5, $3 \mathrm{~cm}$, to 26X-5W, $9 \mathrm{~cm}$; 220.53$220.59 \mathrm{mbsf}$ ), the nannofossil assemblages are of low diversity and dominated by calcisphere carbonate and several Cretaceous mass extinction survivor species, including Cyclagelosphaera reinhardtii, Markalius inversus, and Zeugrhabdotus sigmoides. Samples immediately below the boundary contain abundant and highly diverse uppermost Maastrichtian nannofossil assemblages.

The Maastrichtian Zones/Subzones UC20d through UC20a/19 are recognized using the base of Micula prinsii in Sample 342-U1403A-26X-CC (224.16 mbsf), the base of Ceratolithoides kamptneri in Sample 342-U1403B-28X-5, $50 \mathrm{~cm}$ (223.1 mbsf), the base of Micula murus in Sample 342-U1403B-30X-4, $40 \mathrm{~cm}$ (240.9 mbsf), and the top of Reinhardtites levis in Sample 342-U1403B-31X-3, $52 \mathrm{~cm}$ (249.22 mbsf). We are unable to differentiate Subzone UC20a because of the rare and sporadic distribution of Lithraphidites quadratus in the lower part of its range. The presence of common Cribrocorona echinus in Sample 342U1403B-31X-3W, $52 \mathrm{~cm}$ (249.22 mbsf), is suggestive of Zones UC17-UC18, and its top occurs just prior to the mid-Maastrichtian event in the Pacific (Lees and Bown, 2005). The absence of definitive Tranolithus orionatus (base of Zone UC18 marker species) lower in the section indicates that this species may not be present at Site U1403. The coincident tops of Uniplanarius trifidus and Broinsonia parca constricta in Sample 342-U1403B-31X-4, $18 \mathrm{~cm}$ (250.38 mbsf), indicate an age no younger than the Zone UC17/UC16 boundary. As these two events have been estimated as lying $0.71 \mathrm{~m} . \mathrm{y}$. apart, the coincident tops recorded here suggest the presence of a hiatus or stratigraphic condensation at this level. These two taxa are present to just above the lowermost sediment in the hole (Sample 342-U1403B-32X-3, 28 cm; 258.68 mbsf), 
indicating that this lowermost sediment is of late Campanian-earliest Maastrichtian age (Zones/Subzones UC16-UC15dT). The deepest core catcher sample, 342-U1403B-32X-CC, is barren of nannofossils.

\section{Radiolarians}

Radiolarian biostratigraphy is based on analysis of all core catcher samples from Hole U1403A, selected core catcher samples from the upper part of Hole U1403B (Cores 342-U1493B-1H through 8H), and additional section-half samples from Hole U1403B for the upper part of the hole (Cores $1 \mathrm{H}$ through $10 \mathrm{H})$, the Paleocene-Eocene transition (Core 23X), and the deepest Cretaceous core (Core 32X). Radiolarians occur sporadically and are poorly preserved in the undated upper part of Site U1403. They are abundant and well preserved through middle and lower Eocene, common and relatively poorly preserved through the Paleocene-Eocene transition, and rare and poorly preserved in the lower Paleocene and Cretaceous. Depth positions and age estimates of biostratigraphic marker events are shown in Table $\mathrm{T} 5$, and the radiolarian distribution is shown in Table T6. Note that the distribution chart is based on shipboard study and is biased toward age-diagnostic species and distinctive morphotypes.

The uppermost interval from Samples 342-U1403A$1 \mathrm{H}-\mathrm{CC}$ to $5 \mathrm{H}-\mathrm{CC}(5.85-43.84 \mathrm{mbsf})$ is barren or contains only rare and poorly preserved radiolarians. The underlying interval from Samples $6 \mathrm{H}-\mathrm{CC}$ through 7H-CC (53.69-63.18 mbsf) contains common spumellarian radiolarians, which are poorly preserved and not age diagnostic. In the lower part of the correlated interval in Hole U1403B, rare, poorly preserved nassellarian radiolarians are tentatively referred to the genera Podocyrtis and Theocyrtis and suggest an Eocene age for the interval from 342U1403B-8H-2, 66-68 cm, through 8H-CC (56.0763.97 mbsf).

Radiolarians are abundant and generally well preserved in Hole U1403A from Samples 342-U1403A8H-CC through 19X-CC (73.01-165.65 mbsf) and are assigned to Eocene radiolarian Zones RP12-RP9. The radiolarian assemblages are diverse and have many taxa in common with the low-latitude assemblages that form the basis of the Cenozoic radiolarian zonation. The top of this radiolarian-rich interval is bracketed in Hole U1403B by Samples 342U1403B-8H-CC and 9H-3, 50-52 cm (63.97-66.91 mbsf). The radiolarian assemblage in the latter sample is assigned to Zone RP13 based on the base of Eusyringium fistuligerum. Samples 342-U1403B-10H-2, $120-122 \mathrm{~cm}$, and $10 \mathrm{H}-5,50-52 \mathrm{~cm}$ (75.56-79.26 mbsf), and the interval in Hole U1403A from Samples 342-U1403A-8H-CC through 11H-CC (73.01101.15 mbsf) are correlated with Zone RP12 based on the presence of Eusyringium lagena. The evolutionary transition (or faunal crossover) from Thyrsocyrtis tensa to Thyrsocyrtis triacantha occurs in the lower part of this zone in Sample 342-U1403A-10H-CC (91.91 mbsf). Other key bioevents recorded in the zone include the bases of Podocyrtis diamesa, Theocotyle nigriniae, and Thyrsocyrtis hirsuta.

Identification of the two underlying zones is based on single samples in Hole U1403A. Zone RP11 is identified by the base of Dictyoprora mongolfieri in Sample 342-U1403A-8H-CC (110.87 mbsf), and Zone RP10 is identified by the faunal crossover from Theocotyle nigriniae to Theocotyle cryptocephala mongolfieri in Sample 342-U1403A-13H-CC (120.23 mbsf).

The interval in Hole U1403A from Samples 342U1403A-14H-CC to 18X-CC (129.77-148.77 mbsf) is correlated with Zone RP9 using the base of Lychnocanoma bellum in the lowermost sample. Other key bioevents recorded in this zone include the bases of Podocyrtis diamesa and Thyrsocyrtis rhizodon.

Sample 342-U1403A-19X-CC (165.63 mbsf) is correlated with Zone RP8 using the base of T. hirsuta.

Cores 342-U1403A-20X and 21X contain common to abundant radiolarians of moderate to poor preservation. Samples 342-U1403A-20X-CC and 21X-CC (175.45-185.14 mbsf) are correlated with the Eocene part of Zone RP7 based on the base of both Podocyrtis papalis and Theocorys? phyzella. These two bioevents occur within the PETM at Ocean Drilling Program (ODP) Site 1051, Blake Nose (Sanfilippo and Blome, 2001), and at Mead Stream, New Zealand (Hollis et al., 2005). Other key bioevents that occur within this interval include the bases of Bekoma bidartensis (zonal marker), Amphicraspedum prolixum gr., and Calocyclas castum and the top of Amphisphaera goruna.

Radiolarians are common to few but poorly preserved in Cores 342-U1403A-22X through 25X. Samples 342-U1403A-22X-CC and 23X-CC (188.69204.32 mbsf) are assigned to Zones RP5-RP6 based on the base of Buryella tetradica in the lowermost sample. Samples from Cores 24X and 25X lack agediagnostic species.

Radiolarians are rare and generally poorly preserved in Cores 342-U1403A-26X through 28X (224.21$242.3 \mathrm{mbsf}$ ) and in the lowermost core catcher sample from Hole U1403B (342-U1403B-32X-CC; 261.9 mbsf). Further higher resolution sampling of this interval may yield age-diagnostic species, especially in the Cretaceous where nassellarians have been noted in the foraminifer samples. 


\section{Planktonic foraminifers}

Core catchers were sampled principally from Hole U1403A, and additional Cretaceous samples were taken in Hole U1403B from intervals of light-colored sediment. Samples were, for the most part, barren of planktonic foraminifers except for thin carbonaterich intervals in the lower Eocene and lower Paleocene. The Cretaceous samples consistently contain rare to few planktonic foraminifer specimens. Preservation is poor except in samples from Cores 342U1403B-29X through 31X (234.66-251.90 mbsf). Thus, planktonic foraminifers are of limited use in the development of a biostratigraphy and for correlation between the two holes at this site. Depth positions and age estimates of biostratigraphic marker events identified are shown in Table T7. Abundances and preservation are shown in Table T8 and Figure F17. When recovered, planktonic foraminifer assemblages show evidence of dissolution, are moderately to poorly preserved, and have relatively low species diversities (typically $\sim 3-6$ species in the lower Paleogene and $\sim 1-3$ in the Upper Cretaceous). The sporadic occurrence of planktonic foraminifers at Site U1403 is the result of dissolution below or close to the CCD.

In Core 342-U1403A-20X, a poorly preserved lower Eocene-upper Paleocene assemblage was recovered containing the marker species Acarinina coalingensis, Acarinina soldadoensis, Morozovella subbotinae, and Subbotina velascoensis, indicating Zone E4 to Paleocene P4c (Sections 342-U1403A-20X-1 to 20X-5; 166.49-172.57 mbsf) and Zones E2-P5 (Sections 20X-6 to 20X-CC; 173.96-175.45 mbsf). Chiloguembelina wilcoxensis is a good biostratigraphic marker for the lower Eocene at Site U1403 and occurs in Samples 342-U1403A-20X-1, 78-80 cm, to 20X-CC (166.49-175.45 mbsf). Further differentiation of Eocene biozones was hindered by the absence of key taxa.

Samples 342-U1403A-23X-6, 48-50 cm, to 23X-7, 15-17 cm (202.59-203.66 mbsf), contain a poorly preserved early Paleocene assemblage. The presence of Parasubbotina varianta, Praemurica inconstans, Morozovella angulata, and Subbotina triloculinoides enables the identification of Zone P4 to Subzone P1c.

The nannofossil ooze recovered in Sections 342U1403A-26X-1 through 26X-5 (214.5-222 mbsf) contains a good to very well preserved assemblage of lowest Paleocene planktonic foraminifers. Species identified in the assemblage include Chiloguembelina morsei, Eoglobigerina edita, Eoglobigerina eobulloides, Praemurica pseudoinconstans, Praemurica taurica, and Subbotina trivalis. This assemblage is assigned to planktonic foraminifer Zone $\mathrm{P} \alpha$ to Subzone P1b, consistent with the nannofossil results for this interval.

The K/Pg boundary was recovered in both holes, toward the top of Sections 342-U1403A-26X-5 and 342-U1403B-28X-1 (220.5-235.4 mbsf). Above the K/Pg boundary, Sample 342-U1403A-26X-5, 3-4 cm (220.54 mbsf), contains well-preserved lowest Paleocene faunas (E. eobulloides and E. edita) associated with reworked upper Maastrichtian specimens. However, the samples below the K/Pg boundary (Sample 342-U1403A-26X-5W, 22-24 cm; $220.73 \mathrm{mbsf}$ ) include only small specimens of hedbergellids. Cores 342-U1402B-29X through 30X (226.3-245.7 mbsf) contain well-preserved assemblages consisting of Contusotruncana (C. contusa, C. fornicata, and C. patelliformis), Globotruncana (G. bulloides, G. linneana, and $G$. ventricosa), and Globotruncanita (G. stuarti and $G$. stuartiformis) with some Heterohelix species (H. globulosa and $H$. navarroensis). The assemblage includes tropical Maastrichtian-Campanian faunas of C. contusa, Gansserina gansseri, and Globotruncana aegyptiaca. However, the Maastrichtian marker species Abathomphalus mayaroensis is absent. The co-occurrence of C. contusa, G. linneana, G. bulloides, and G. ventricosa suggests an early Maastrichtian age.

In other samples from Cores 342-U1403A-26X through 28X (214.5-253.3 mbsf) and Core 342U1403B-32X (255.4-261.91 mbsf), the planktonic foraminifer assemblage is impoverished and poorly to moderately preserved. Typical constituents of the assemblage are Hedbergella cf. H. monmouthensis, Hedbergella holmdelensis, Globotruncanella petaloidea, and $H$. navarroensis. Because many of the marker species are absent (e.g., Abathomphalus mayaroensis, Pseudoguembelina hariaensis, Pseudoguembelina palpebra, and Racemiguembelina fructicosa), differentiation of individual biozones is not possible for the Maastrichtian and Campanian.

\section{Benthic foraminifers}

Benthic foraminifers were examined semiquantitatively in core catcher samples from Hole U1403A and from core catcher samples taken in the Cretaceous section of Hole U1403B (Cores 342-U1403B$29 \mathrm{X}$ through $32 \mathrm{X}$ ). Additional samples taken from selected sections in Holes U1403A and U1403B were examined for preservation and relative abundance of total benthic foraminifers and individual morphogroups. Benthic foraminifers at this site are rare relative to total sediment particles $>150 \mu \mathrm{m}$ in the lower Eocene to lower Paleocene but become dominant throughout the Campanian to Maastrichtian. Faunas generally suggest a lower bathyal to abyssal paleodepth for this site (van Morkhoven et al., 1986). 
Preservation of foraminifer tests is generally moderate to good (Fig. F17). The occurrences of benthic foraminifers at this site are shown in Tables T9 and T10.

The uppermost sample (342-U1403A-1H-CC; 5.83 mbsf) yields only a few benthic foraminifer specimens including Cibicides sp., Nuttallides decorata?, and Pullenia subcarinata, most probably a result of dissolution below the CCD.

Lithostratigraphic Units II and III are predominantly barren of benthic foraminifers. The benthic foraminifer fauna in Samples 342-U1403A-3H-CC, 4H-CC, $6 \mathrm{H}-\mathrm{CC}, 12 \mathrm{H}-\mathrm{CC}$, and $13 \mathrm{H}-\mathrm{CC}$ are characterized by agglutinated taxa (mainly Bathysiphon sp.) and a few poorly preserved calcareous specimens in Samples 342-U1403A-12H-CC and 13H-CC.

Samples 342-U1403A-13H-CC through 20X-CC (120.33-175.45 mbsf) are characterized by Eocene assemblages that are mainly dominated by calcareous taxa, such as Abysammina poagi, Anomalina spissiformis, Cibicidoides mexicanus, Cibicidoides praemundulus, and Nuttallides truempyi. Preservation of these assemblages is poor to moderate but improves significantly in Samples 342-U1403A-19X-CC and 20X-CC. Two Eocene samples studied are barren of benthic foraminifers (Samples 14H-CC and 17H-CC).

The underlying Samples 342-U1403A-21X-CC and 22X-CC contain only sporadic benthic foraminifers. Agglutinated forms, such as Bathysiphon sp., Hormonisella sp., Glomospira sp., and Saccammina sp., are found together with some poorly preserved calcareous forms.

Paleocene to Campanian Samples 342-U1403A-23XCC through 28X-CC and 342-U1403B-29X-CC through $32 \mathrm{X}-\mathrm{CC}$ contain diverse calcareous benthic foraminifer assemblages. Diversity increases downhole and peaks in the Maastrichtian to Campanian. The assemblages are dominated by Gavelinella beccariiformis and N. truempyi. Abundant calcareous taxa are typically Anomalina praeacuta, Aragonia velascoensis, Gyroidinoides globosus, Lenticulina cf. adenalensis, and Nuttallinella florealis. Agglutinated forms identified include abundant Dorothia trochoides and Gaudryina pyramidata, whereas Bathysiphon sp., Rhizammina sp., and Rhabdammina sp. are subordinate. Preservation of these forms is moderate to good. Benthic foraminifers are the dominant component in the $>150 \mu \mathrm{m}$ fraction in the Cretaceous sediment at Site U1403.

The benthic foraminifer species Reussella szajnochae is found in Samples 342-U1403B-31X-4, 89-91 cm, through 32X-CC (251.10-261.89 mbsf). R. szajnochae is considered to be a low-latitude taxon that favors warm bottom water (Widmark, 1995) and is hypoth- esized to disappear during a shift in ocean circulation during the early Maastrichtian, which marks the first appearance of colder southern-component water masses. In Hole U1403B, the top of $R$. szajnochae at Sample 342-U1403B-31X-4, 89-91 cm (251.10 mbsf), is coincident with the last occurrence of inoceramid prisms in Sample 342-U1403B-31X-4, 89-91 $\mathrm{cm}$ (251.10 mbsf). This observation might indicate cooling in North Atlantic bottom water.

\section{Paleomagnetism}

We completed a paleomagnetism study of APC and XCB cores from Holes U1403A and U1403B with the primary objective of establishing magnetostratigraphy of the site to provide chronostratigraphic age control. The natural remanent magnetization of each archive-half section was measured at $2.5 \mathrm{~cm}$ intervals before and after demagnetization treatment in a peak alternating field (AF) of $20 \mathrm{mT}$. We processed the archive-half section measurement data by removing measurements made within $7.5 \mathrm{~cm}$ of section ends and from disturbed intervals described in the Laboratory Information Management System database. Cores 342-U1403A-1H through $16 \mathrm{H}$ and 342U1403B-1H through 9H were azimuthally oriented using the FlexIT tool (Table T11); all other cores were not oriented.

We also took 164 discrete samples from working-half sections to verify the archive-half section measurement data and to measure the anisotropy of magnetic susceptibility (AMS) and bulk susceptibility of Site U1403 sediment. Discrete samples were collected and stored in $7 \mathrm{~cm}^{3}$ plastic cubes and were typically taken from the least disturbed region closest to the center of each section. In general, samples were collected at $\sim 1.5 \mathrm{~m}$ intervals from Cores 342U1403A-1H through $16 \mathrm{H}$ and $23 \mathrm{X}$ through $28 \mathrm{X}$ and $342-$ U1403B-19H through $22 \mathrm{H}, 23 \mathrm{X}$ through $25 \mathrm{X}$, and $28 \mathrm{X}$ through $32 \mathrm{X}$. The samples were first subjected to AMS measurements, including bulk susceptibility. Subsequently, they were step-wise AF demagnetized at 10 and $20 \mathrm{mT}$. Forty samples were further step-wise demagnetized to 60 or $80 \mathrm{mT}$. All discrete sample data were volume corrected to $7 \mathrm{~cm}^{3}$.

\section{Results}

Downhole paleomagnetism data after $20 \mathrm{mT}$ demagnetization are presented for Holes U1403A and U1403B in Figures F18 and F19. Three prominent features are evident:

1. Magnetic intensity lows occur at several horizons (e.g., between $\sim 15$ and $\sim 35, \sim 95$ and 130, and $\sim 160$ and $170 \mathrm{mbsf}$ ), 
2. Inclination is biased toward positive values, and

3 . $\sim 180^{\circ}$ alternations are seen in declination records for APC cores.

\section{Low-intensity zones}

Magnetic intensity lows are most frequently associated with distinctive blue-gray sediment intervals in the cores (see "Lithostratigraphy"). Magnetic susceptibility values are also very low within these intervals, indicating either a lower initial supply of paramagnetic and ferromagnetic minerals or diagenetic loss of these materials in these intervals. We favor the interpretation that the magnetic intensity lows are caused by reductive dissolution, which is common in oceanic sediment. We note that it was often difficult to obtain meaningful paleomagnetic signals from these horizons because diagenesis has obscured the primary magnetic signal.

\section{Inclination bias}

Inclination bias indicates that a substantial drilling overprint exists even with the use of nonmagnetic core barrels and cutting shoes and after $20 \mathrm{mT}$ demagnetization. Considering the latitude of Site $\mathrm{U} 1403\left(\sim 40^{\circ} \mathrm{N}\right)$, reversal sequences should be characterized by distinct inclination alternations between $\sim 60^{\circ}$ and approximately $-60^{\circ}$. However, there are very few horizons in which we observe $-60^{\circ}$ inclinations. Because of this strong inclination biasing, identifying the paleomagnetic polarity solely based on shipboard inclination data is nearly impossible.

\section{Declination trends}

At low to middle latitudes, reversal sequences often can be identified from declination patterns. Indeed, the $\sim 180^{\circ}$ alternations in declination observed in Site U1403 cores are consistent with polarity transitions. Declination variations illustrated for the "oriented APC" intervals in Figures F18 and F19 are in geographical coordinates (corrected using the FlexIT core orientation tool). We interpret the intervals with declination of $\sim 0^{\circ}\left(\sim 180^{\circ}\right)$ to indicate normal (reversed) magnetozones. A magnetozone with a primary normal polarity should not display inclinations less than $\sim 40^{\circ}$, barring sedimentary inclination-shallowing biases. Notably, intervals with $\sim 180^{\circ}$ declination often have inclination values that are systematically shallower than those in the intervals with declination of $\sim 0^{\circ}$ (e.g., $\sim 50-140 \mathrm{mbsf}$ in Hole U1403A and $~ 50-70$ mbsf in Hole U1403B; Figs. F18, F19). Thus, the drilling overprint mainly obscured remanent inclination but not declination. Shipboard demagnetization to $20 \mathrm{mT}$ can only partially remove this persistent vertical overprint, result- ing in positive polarity magnetozones with inclination values ranging from $\sim 50^{\circ}$ and higher and negative polarity magnetozones with inclination values from $\sim 40^{\circ}$ to $-60^{\circ}$. In some cases, shipboard demagnetization of discrete samples verified these trends (see below), but thorough shore-based demagnetization experiments will help clarify intervals with ambiguous or indeterminable polarity.

\section{Comparison between pass-through and discrete sample data}

AF demagnetization results for discrete samples are summarized in Tables T12 and T13. Of the 40 samples subjected to step-wise AF demagnetization by 60 or $80 \mathrm{mT}$, only 11 reveal stable components of magnetization (e.g., Fig. F20A, F20B). For the other samples, drilling overprints are too severe to reveal primary components (Fig. F20C). Nevertheless, these results are still useful for verifying the $20 \mathrm{mT}$ passthrough paleomagnetism data from the archive-half sections. Magnetization intensity and declination are generally consistent between the discrete samples and the archive-half samples (Figs. F18, F19).

We note that inclinations measured in discrete samples are often more shallow than the counterpart values in the archive-half samples. This trend is particularly evident in the "oriented APC" intervals with declinations of $\sim 180^{\circ}$ (e.g., $~ 50-140 \mathrm{mbsf}$ in Fig. F18). These inclination-shallowing trends are consistent with the reversed polarity intervals suggested from the declination. Discordance between inclination measured in the discrete samples and the archive-half sections is substantial in $\mathrm{XCB}$ intervals (e.g., 180-250 mbsf in Fig. F19). We caution that any magnetozone interpretations based on the archive-half section measurement data for the $\mathrm{XCB}$ intervals without more thorough demagnetization procedures may be prone to misinterpretations.

In summary, paleomagnetism data from archive-half sections and discrete samples from oriented core intervals generally agree well and reveal a continuous series of magnetozones from Sections 342-U1403A$6 \mathrm{H}-2$ to $16 \mathrm{H}-2$ (46.57-140.30 mbsf) and 342U1403B-6H-5 to $16 \mathrm{H}-5$ (41.86-136.91 mbsf). Moreover, our shipboard demagnetization results indicate that shore-based measurements are required to interpret archive-half section measurement data to identify and fully characterize magnetozones in nonoriented core intervals.

\section{Magnetostratigraphy}

Identification of magnetozones and correlation to the geomagnetic polarity timescale (GPTS) was most straightforward for azimuthally oriented APC inter- 
vals (Cores 342-U1403A-1H through $16 \mathrm{H}$ and 342 U1403B-1H through 9H) (Fig. F21). Our general strategy was to identify magnetozones first by using inclination reversals but more frequently by using declination reversals from oriented cores. Intervals with downward and northerly $\left(\sim 0^{\circ}\right)$ magnetizations are assigned normal polarity, whereas intervals with low-to-upward and southerly $\left(\sim 180^{\circ}\right)$ declinations indicate reversed polarity. This approach yields several normal and reversed magnetozones throughout Holes U1403A and U1403B, including a continuous series from Sections 342-U1403A-6H-1 to $16 \mathrm{H}-2$ $(\sim 46-140 \mathrm{mbsf})$ and $342-\mathrm{U} 1403 \mathrm{~B}-6 \mathrm{H}-5$ to $16 \mathrm{H}-5$ ( 41-137 mbsf).

By utilizing robust radiolarian and nannofossil biostratigraphy from Core 342-U1403A-16H (see "Biostratigraphy"), we can correlate the continuous series of magnetozones uphole through Site U1403 to an early to late Eocene magnetostratigraphy. This correlation is corroborated by radiolarian biostratigraphy in Cores $342-\mathrm{U} 1403 \mathrm{~A}-8 \mathrm{H}$ through $15 \mathrm{H}$. In Hole U1403A, we identified Chrons C16n.2n (36.051-36.700 Ma) to C22n (48.566-49.344 Ma) from 46.57 to $140.30 \mathrm{mbsf}$. In Hole U1403B, we identified Chrons C16n.1r (35.892-36.051 Ma) to C22n (48.566-49.344 Ma) from 41.86 to 136.91 mbsf. Although distinct magnetozones are evident above these intervals, we cannot correlate them to the GPTS because the series does not match the GPTS reversal pattern, and we lack biostratigraphic age control to independently anchor these series in time. Strong drilling-induced overprinting has obscured the primary magnetostratigraphy in cores recovered using the XCB coring system, so we refrain from correlating these intervals to the GPTS until we have completed thorough demagnetization experiments on these cores. The magnetostratigraphic age model for Site U1403 is summarized and presented in Table T14 and Figures F18, F19, and F21.

The magnetostratigraphic age model for Site U1403 allows for precise dating of clay-rich and fossiliferously poor lithostratigraphic Units II and III (see "Lithostratigraphy"). The magnetostratigraphy at Site U1403 verifies the high clay sedimentation rates implied by the radiolarian biostratigraphy (see "Biostratigraphy"). These results indicate that from the beginning of Chron C22n to the end of Chron C20n (49.344-43.301 Ma), clay accumulated at Site U1403 at over twice the rate seen during Chrons C19r to C16n.1r (43.301-35.892 Ma).

Site U1403 magnetostratigraphy also suggests that the distinctive gray-blue interval at 342-U1403A-6H$2,80-120 \mathrm{~cm}$, and 342-U1403B-6H-5, 50-90 cm, was deposited during Chron C16n.1n (35.706-35.892 Ma). This stratigraphic interval is characterized by low magnetic susceptibility, a peak in NGR, and the presence of euhedral silicate minerals that have been tentatively identified as feldspars (Fig. F14). We tentatively conclude that this interval marks the Chesapeake Bay impact event, which occurred within Chron C16n.1n (Coccioni et al., 2009). We note that a lithologically similar gray-blue bed is present at Site U1404, but at that site the magnetochronology and biostratigraphy are consistent with deposition just above the Chron C17n.1r/C17n.2n boundary. We are more confident in the magnetostratography at Site U1404 than that at Site U1403. Therefore, the gray-blue bed at Site U1403 is either a separate event from that at Site U1404, or the identification of Chron 16n at Site U1403 is incorrect.

\section{Magnetic susceptibility and anisotropy of magnetic susceptibility}

Bulk magnetic susceptibility measured on discrete samples is summarized in Tables T15 and T16. Downhole variation for whole-round magnetic susceptibility (WRMS) and discrete sample magnetic susceptibility (DSMS) are shown in Figure F18. We multiplied the WRMS data, which are in instrument units, by a factor of $0.577 \times 10^{-5}$ to convert to approximate SI volume susceptibilities (see "Paleomagnetism" in the "Methods" chapter [Norris et al., 2014b]). WRMS and DSMS data agree well, and we attribute small absolute differences to the fact that the conversion factor applied to the WRMS data is not constant downhole because of changes in core diameter and density; only discrete samples provide calibrated susceptibility values in SI units. Nevertheless, both magnetic susceptibility data sets show the same first- and second-order cyclic trends, indicating that these trends are robust features of Site U1403 sediment.

AMS results for the discrete samples are also summarized in Tables T15 and T16 and are shown in Figures F22 and F23. The eigenvalues associated with the maximum $\left(\tau_{1}\right)$, intermediate $\left(\tau_{2}\right)$, and minimum $\left(\tau_{3}\right)$ magnetic susceptibilities at Site U1403 are tightly clustered downhole to $120 \mathrm{mbsf}$, indicating an isotropic magnetic fabric. Magnetic anisotropy increases and becomes more oblate with depth in both Holes U1403A and U1403B. We note that the inclination of the minimum eigenvector $\left(\mathrm{V}_{3}\right)$ is highly variable in APC cores but is clustered toward nearvertical values in XCB cores. Similarly, the degree of anisotropy $\left(P ; \tau_{1} / \tau_{3}\right)$ is generally highest in $\mathrm{XCB}$ cores, with a notable exception in Cores 342U1403A-13H through $16 \mathrm{H}$ and 342-U1403B-19H through $22 \mathrm{H}$, in which $P$ is remarkably high. In Cores 342-U1403A-13H through $16 \mathrm{H}$, the high $P$ values correspond to intervals with lower clay content, 
lowest bulk density, and greatest porosity (Fig. F22). These observations suggest that magnetic anisotropy is largely controlled by lithology (i.e., grain size) rather than coring method in APC-recovered intervals. However, subhorizontal oblate fabrics are most evident in intervals recovered by $\mathrm{XCB}$ in Holes U1403A and U1403B, even in clay-rich horizons at these depths. We attribute this strong magnetic anisotropy to the compounded effects of burial, drilling-induced compaction, and biscuiting characteristic of XCB coring.

\section{Age-depth models and mass accumulation rates}

Coring at Site U1403 recovered a $265 \mathrm{~m}$ thick sequence of Quaternary-upper Campanian clay, radiolarian clay, and nannofossil ooze with minor chert layers. Biostratigraphic datums and magnetostratigraphic datums from Hole U1403A and the base of Hole U1403B (Table T17) were compiled to construct an age-depth model for this site (Fig. F16). Selected datums (Table T18) were used to calculate linear sedimentation rates (LSRs). Total mass accumulation rate (MAR), carbonate MAR (CAR), and noncarbonate MAR (nCAR) were calculated at 0.2 m.y. intervals using a preliminary shipboard splice rather than the "sampling splice" described in this volume (Table T19; Fig. F24).

\section{Age-depth model}

The main objective at Site U1403 was to recover a complete and well-resolved upper Campanian to upper Eocene section, and the site was positioned to yield this critical stratigraphic interval at a relatively shallow burial depth. The sediment section in Hole $\mathrm{U} 1403 \mathrm{~A}$ is therefore relatively condensed through the lower Eocene to Pleistocene section (Fig. F16). The age-depth model is tied to Pleistocene nannofossil datums and Eocene paleomagnetic datums in the upper 65 mbsf. Through the middle and upper lower Eocene, paleomagnetic datums provide the primary tie points, supported by radiolarian datums in the upper 65-119 mbsf and nannofossil datums in the lower 119-140 mbsf. Radiolarian datums exhibit wide scatter through the Eocene, suggesting that they are either poorly calibrated to the GPTS or that they are diachronous in the North Atlantic. Below 140 mbsf, we relied primarily upon calcareous nannofossil datums to define the age-depth model, although radiolarians provide tie points in the lowermost Eocene. Nannofossil and planktonic foraminiferal datums are in good agreement in the lower Paleocene and Upper Cretaceous.

\section{Linear sedimentation and mass accumulation rates}

LSRs at Site U1403 show peaks between 1.0 and 1.6 $\mathrm{cm} / \mathrm{k}$.y. above background rates, which are generally $<0.5 \mathrm{~cm} / \mathrm{k} . \mathrm{y}$. MARs at Site U1403 show three distinct peaks, one each in the Maastrichtian, lower Eocene, and middle Eocene (Fig. F24). MAR peaks are driven by changes in LSR. The three MAR peaks are similar to each other in magnitude $(1.55,1.57$, and 1.24 $\mathrm{g} / \mathrm{cm}^{2} / \mathrm{k} . \mathrm{y}$., respectively); however, the contribution of carbonate to overall mass accumulation at Site U1403 progressively decreases toward the present, presumably in response to subsidence and superimposed changes in the local CCD. A smaller MAR maximum occurs in the lower Eocene that appears to be driven by changes in carbonate content. Accumulation of sediment between the MAR peaks occurs at background rates of $0.4 \mathrm{~g} / \mathrm{cm}^{2} / \mathrm{k} . \mathrm{y}$.

\section{Maastrichtian}

In the Maastrichtian, MARs peak at $1.55 \mathrm{~g} / \mathrm{cm}^{2} / \mathrm{k} . \mathrm{y}$. High carbonate content relative to the Paleocene indicates that much of this accumulation was driven by carbonate sedimentation, caused either by increased production, enhanced preservation, or a combination of both. The Maastrichtian MAR peak ends at $\sim 68 \mathrm{Ma}$, corresponding to a decrease in LSR (Fig. F24).

\section{Paleocene}

In the Paleocene, MAR is at background levels of $\sim 0.4 \mathrm{~g} / \mathrm{cm}^{2} / \mathrm{k}$.y. and generally dominated by noncarbonate components.

\section{Lower Eocene}

MAR sharply increase at the Paleocene/Eocene boundary to values $\sim 1.6 \mathrm{~g} / \mathrm{cm}^{2} / \mathrm{k}$.y. This increase is driven by high rates of nCAR and may be related to climatic changes associated with the PETM (see "Lithostratigraphy" and "Geochemistry"). Lower Eocene MAR continues to increase to a maximum $\sim 54 \mathrm{Ma}$ as carbonate accumulation ramps up. Prior to the end of the peak, CAR accounts for $40 \%$ of the MAR. The lower Eocene MAR peak terminates at a hiatus at $53.5 \mathrm{Ma}$, identified by the co-occurrence of diachronous biostratigraphic datums (see "Agedepth model" and "Biostratigraphy").

\section{Middle Eocene}

In the middle Eocene, MAR peaks at $1.24 \mathrm{~g} / \mathrm{cm}^{2} / \mathrm{k} . \mathrm{y}$. at $46 \mathrm{Ma}$. The majority of the accumulation during this peak is contributed by noncarbonate components, as carbonate weight percent values fall to near 
$0 \mathrm{wt} \%$ in sediment younger than $46 \mathrm{Ma}$. MAR values step down between $45 \mathrm{Ma}$ and $39 \mathrm{Ma}$ and are stable at $\sim 0.1 \mathrm{~g} / \mathrm{cm}^{2} / \mathrm{k}$.y. through the rest of the sequence.

\section{Geochemistry}

The geochemistry program during operations at Site U1403 included

- Analysis of interstitial gas compounds of headspace samples from Hole U1403A;

- Measurement of minor and trace element concentrations in interstitial water squeezed from whole-round samples from Hole U1403A; and

- Inorganic carbon, total carbon, and total nitrogen determinations of solid sediment samples from multiple holes.

\section{Headspace gas samples}

Twenty-five headspace gas samples were analyzed (Table T20) at a frequency of one sample per core in Hole U1403A as part of the routine environmental protection and safety monitoring program. The concentration of methane in most of the samples was close to detection limits (2.01 ppmv) and gradually increased to $16.19 \mathrm{ppmv}$ with depth (maximum depth $=241.45 \mathrm{mbsf})$. The uppermost samples (Cores 342-U1403A-1H through 5H) have lower values than samples from below Core $6 \mathrm{H}$, which also exhibit higher variability. Other hydrocarbon gases were not detected, which is consistent with the low organic carbon content of these sediments (see "Sediment geochemistry").

\section{Interstitial water geochemistry}

Sixteen interstitial water samples were collected from Hole U1403A at a resolution of typically one sample per core (Table T21). Interstitial water samples were squeezed from $5 \mathrm{~cm}$ whole rounds taken on the catwalk. Most interstitial water samples were collected from the bottom of Section 6 or the bottom of Section 1 in a given core, depending on core disturbances visible through the core liner and proximity to intervals critical for stratigraphic correlation. Samples were not collected from key boundary intervals to preserve the stratigraphic integrity of the cores for future sampling. See "Lithostratigraphy" and "Stratigraphic correlation" for information on unit boundaries. Chemical constituents were determined according to the procedures outlined in "Geochemistry" in the "Methods" chapter (Norris et al., 2014b).

\section{Salinity, pH, alkalinity, chloride, and sodium}

The $\mathrm{pH}$ of interstitial water at Site U1403 ranges from 7.0 to 7.4, with higher values of 7.2-7.4 above
50 mbsf and fluctuating between 7.0 and 7.2 at greater depth. All values are lower than the average range of seawater $\mathrm{pH}, 7.7-8.1$. Salinity ranges from $36 \%$ o to $38 \%$, slightly higher than the average salinity of modern seawater (35\%), and shows a slight increasing downhole trend.

Alkalinity is relatively constant with depth, with most values between 3 and $4.5 \mathrm{mM}$. Exceptions are an anomalously high value of $\sim 5.5 \mathrm{mM}$ in Core 342 U1403A-8H and a low value of $\sim 2.5 \mathrm{mM}$ in Core $9 \mathrm{H}$. All interstitial water samples have a higher alkalinity than average seawater $(2.33 \mathrm{mM}$; International Association of Physical Sciences of the Ocean certified value).

Chloride concentrations were determined by manual titration and ion chromatography. The ion chromatography values are consistently offset to higher values compared to the manual titrations, which may have resulted from an aging ion chromatography column during analysis of Hole U1403A samples. Overall, chloride concentrations exhibit small fluctuations on a slightly increasing trend with depth. The sodium profile exhibits a decreasing trend with depth, with values of $490-525 \mathrm{mM}$ above $170 \mathrm{mbsf}$ and values of $480 \mathrm{mM}$ or less below.

\section{Carbonate crystallization and clay diagenesis as drivers of interstitial water profiles}

Site U1403 downhole trends in potassium, calcium, and magnesium are consistent with those resulting from exchange and alteration with basaltic basement at depth (Gieskes, 1981), with potassium and magnesium decreasing from 13 to $6 \mathrm{mM}$ and 59 to $37 \mathrm{mM}$, respectively, and calcium increasing from 11 to 49 mM with depth (Fig. F25).

An excursion in interstitial water potassium concentrations centered on the sample taken from Core 342-U1403A-14H coincides with the lithostratigraphic Unit III/IV boundary (see "Lithostratigraphy"). Low potassium levels in this interval are likely to reflect the sorption of potassium onto montmorillonite (Arthur, 1979). Pink blebs in Units III and IV were identified as authigenic montmorillonite by XRD (see "Lithostratigraphy").

Strontium concentrations increase downhole from $80 \mu \mathrm{M}$ in the shallowest sample to $200 \mu \mathrm{M}$. Both calcium and strontium concentrations in interstitial fluid increase steadily downhole in Hole U1403A, whereas the magnesium profile shows a linear decrease with depth. Although calcium and strontium can be influenced by carbonate dissolution and/or recrystallization during calcium carbonate diagenesis (e.g., Baker et al., 1982), there is no evidence for any significant deflection in the interstitial water trends at lithologic boundaries. Also, Sr/Ca exhibits a linear 
decreasing trend (except for a small positive fluctuation within lithostratigraphic Unit III), indicating that the conversion of biogenic carbonate to inorganic calcite is inactive. Hence, the calcium and strontium profiles are interpreted as resulting from diffusional processes. The regular, near-linear downhole profiles displayed by calcium, strontium, and plausibly magnesium indicate that these elements are affected by the same controlling factor at this site.

\section{Sulfate, manganese, and iron}

The sulfate interstitial water profile in Hole U1403A is characterized by a decreasing downhole trend from $30-35 \mathrm{mM}$ in the shallowest samples to $\sim 20$ $\mathrm{mM}$ in the three lowermost samples.

Low alkalinity and high sulfate concentration indicate that sulfate reduction associated with the degradation of sedimentary organic matter (by the action of sulfate-reducing bacteria) has not been effective, presumably because of low organic content. This is consistent with the low methane concentration in headspace gas at this site. The manganese profile exhibits strong increases downhole from 0 to 196.5 $\mu \mathrm{M}$. This trend is explained by general upward diffusion of dissolved manganese and its precipitation under the oxic conditions in the uppermost sediment. There is a small excursion in interstitial water sulfate and manganese concentrations near the lithostratigraphic Unit III/IV boundary (see "Lithostratigraphy"). Interstitial water concentrations of dissolved iron are low and invariant (0-1.5 $\mu \mathrm{M})$.

\section{Sediment geochemistry}

\section{Sediment samples}

Samples for sediment geochemistry were taken at an interval of one per section in Hole U1403A, with the exception of Sections 342-U1403A-21X-2 through 21X-7 and 26X-2 through 26X-5, which were taken at $20 \mathrm{~cm}$ intervals to capture finer scale variations and potential lysocline shifts in sediment that capture the PETM and K/Pg boundary. Six sediment samples were taken from Sections 342-U1403B-26X3 and 26X-4 to cover an interval of alternating light and dark bands in lithostratigraphic Subunit Va that was not observed in Hole U1403A.

\section{Results}

Carbonate determinations by coulometry were made for 248 samples from Site U1403 (Table T22). Calcium carbonate values range from 0.04 to $86 \mathrm{wt} \%$ (Fig. F26). Carbonate content in the uppermost two samples (from Sections 342-U1403A-1H-1 and 1H-2) are 35 and $25 \mathrm{wt} \%$, respectively, and drop to almost zero between Sections $1 \mathrm{H}-3$ and 13H-6. Below Core 342-U1403A-13H, near-zero carbonate contents were measured in three intervals, $\sim 130,180-200$, and $\sim 220$ mbsf. In the lowermost 20 mbsf in Hole U1403A, carbonate contents varied between 63 and $86 \mathrm{wt} \%$, the highest carbonate values measured at Site U1403.

Elemental analysis of Hole U1403A sediment reveals that most of the total carbon in Hole U1403A sediment samples is present as calcium carbonate. All of the samples from Holes U1403A and U1403B were initially analyzed using National Institute of Standards and Technology 1646a Estuarine Sediment reference material (total carbon $=1.65 \mathrm{wt} \%$ ) as calibration material. The calibration range for total carbonate is between $\sim 0.03$ and $0.33 \mathrm{mg}$ (i.e., maximum calibration value of $2.2 \mathrm{wt} \%$ for a typical 15 mg sample; see Table T22). However, as was discovered during operations at Site U1403, the total carbon content of Hole U1403A sediment in highcarbonate samples (maximum value $=86 \mathrm{wt} \%$ $\mathrm{CaCO}_{3}$ ) could be up to $4 \times$ higher than the maximum value used in the total carbon calibration. Thus, in many of the high-carbonate samples from Hole U1403A, the measured total carbon values are overestimated, requiring cross-calibration with a more suitable total carbon standard. We selected La Luna Shale with a total carbon of $11.52 \mathrm{wt} \%$, corresponding to $2.3 \mathrm{mg}$ in $20 \mathrm{mg}$, which was the highest calibration point.

Using the correction model described in "Geochemistry" in the "Methods" chapter (Norris et al., 2014 b), we applied correction to samples with total carbon exceeding $2.2 \mathrm{wt} \%$ (Table T22). Corrected total carbon values range from $<0.1$ to $\sim 12 \mathrm{wt} \%$, which is very close to the range for inorganic carbon $(<0.1-$ $11 \mathrm{wt} \%)$, and show similar variation patterns to carbonate (Fig. F26).

Total organic carbon (TOC) is calculated by subtracting inorganic carbon from total carbon. Because of erroneous initial total carbon values, organic carbon values were also recalculated based on corrected total carbon contents (Table T22). Corrected TOC values vary between $<0.1$ and $3 \mathrm{wt} \%$ (Fig. F26). Excluding organic carbon values in high-carbonate samples, TOC values from low-carbonate samples are generally $<0.5 \mathrm{wt} \%$, with a few values up to $1.5 \mathrm{wt} \%$ in Cores $342-\mathrm{U} 1403 \mathrm{~A}-4 \mathrm{H}$ and $21 \mathrm{X}$ that should be viewed with caution.

Total nitrogen is also reported (Fig. F26), although these values should also be used with caution. Anomalous total nitrogen data were removed because they were generally accompanied by 
anomalous total nitrogen values, as indicated by the standard. Most total nitrogen values vary between $\sim 0$ and $0.2 \mathrm{wt} \%$.

\section{Discussion of critical boundary intervals} Paleocene/Eocene Thermal Maximum

At depths below the Paleocene/Eocene boundary ( 182 mbsf), Site U1403 lacks preserved carbonate, indicating it was deposited at a depth below the late Paleocene CCD. The position of the Paleocene/Eocene boundary in the core is somewhat uncertain because of a lack of biostratigraphic constraints for the upper Paleocene, but a prominent siliceous claystone layer at 182.2 mbsf in Hole U1403A (Fig. F27) may mark its location. Carbonate contents increase rapidly above this layer, quickly reaching $\sim 30 \mathrm{wt} \%$ within a few tens of centimeters, with an abundance of calcareous nannofossils from Subzone NP9b (see "Biostratigraphy"). This abrupt increase could be the first direct evidence of a global carbonate oversaturation event, a CCD overshoot, during the recovery phase associated with the PETM. The carbon cycle model of Dickens et al. (1997) predicts such an overshoot, based on the increased rock weathering rates expected in response to elevated atmospheric $\mathrm{CO}_{2}$ levels. In this model, the accelerated weathering rates increase the supply of alkalinity and dissolved inorganic carbon to the ocean, driving it into carbonate oversaturation and causing the CCD to deepen. Thus the large amounts of carbon released at the onset of the PETM ultimately results in greater preservation of calcium carbonate in sediment, as observed at this site. Carbonate oversaturation has previously been suggested by increased carbonate mass accumulation rates during the PETM recovery at ODP Sites 690 and 1266 (Kelly et al., 2010); however, the evidence of abrupt CCD deepening indicated by the results at Site U1403 places greater constraints on both the magnitude and duration of the excursion in the Atlantic CCD during the PETM recovery phase. These results therefore have the potential to better guide our understanding of carbon cycle perturbations during the PETM and the processes involved in restoring steady-state conditions. A similar increase in carbonate content occurs above the probable location of the ETM2 ( 175 mbsf), suggesting that Site U1403 was situated at an appropriate depth to record evidence of CCD fluctuations through this time interval (Figs. F27).

\section{Cretaceous/Paleogene boundary}

The lithologic expression of the K/Pg boundary at Site U1403 occurs at the contact of lithostratigraphic Subunits Va and Vb (220.5 mbsf in Hole U1403A) (see "Biostratigraphy" and "Lithostratigraphy").
At Site U1403, calcium carbonate varies between 40 and $70 \mathrm{wt} \%$ across the $\mathrm{K} / \mathrm{Pg}$ boundary and is absent in an interval a few meters above the boundary (214-216 mbsf) (Fig. F28).

Sediment above the K/Pg boundary (covering mainly nannofossil Zone NP4 and the Danian-Selandian transition; see "Biostratigraphy") are predominantly biosiliceous calcareous chalks $(<50 \quad$ wt $\%$ $\mathrm{CaCO}_{3}$ ), suggesting that Site U1403 was at or above the CCD during Late Cretaceous time. Foraminiferal tests and calcareous nannofossils are moderately to well preserved in this interval.

\section{Physical properties}

We measured physical properties on whole-round sections, section halves, and discrete samples from section halves. Gamma ray attenuation (GRA) bulk density, magnetic susceptibility, $P$-wave velocity, and NGR measurements were made on whole-round sections using the Whole-Round Multisensor Logger (WRMSL) and NGR Logger. Thermal conductivity measurements could not be performed on Site U1403 samples because of technical problems. Compressional wave velocity was measured on section halves at a frequency of two in each section (at $~ 50$ and $100 \mathrm{~cm}$ ). For moisture and density (MAD) analyses, one discrete sample was collected in each section (at $\sim 1 / 4$ of the section length). Lastly, the Section Half Multisensor Logger (SHMSL) was used to measure spectral reflectance and magnetic susceptibility on archive section halves.

\section{Magnetic susceptibility}

Magnetic susceptibility values in lithostratigraphic Unit I vary from 60 to $100 \mathrm{IU}$ and then show a prominent drop downhole to $20 \mathrm{IU}$ around $20 \mathrm{mbsf}$ (Fig. F29). This decrease probably reflects the transition between the nannofossil ooze of Unit I and clay of the upper part of Unit II. Magnetic susceptibility shows a subsequent downhole increase to relatively constant values ( $35 \mathrm{IU})$ in the lower part of Unit II. Magnetic susceptibility values in Unit III average 20 IU. In the upper part of Unit IV, values decrease to $\sim 5$ IU and show a downhole step increase to $\sim 30 \mathrm{IU}$ at 130 mbsf that is maintained to the base of this unit. Magnetic susceptibility is higher and more variable in Unit V. This last unit is characterized by four large magnetic susceptibility peaks (Fig. F29), which are tentatively associated with

- The C16 event at 110 mbsf,

- The ETM2 transition at 160 mbsf,

- The PETM at 183 mbsf in Hole U1403A and 177 mbsf in Hole U1403B, and 
- The K/Pg boundary at 220 mbsf.

\section{Density and porosity}

Two methods were used to evaluate bulk density at Site U1403. The GRA method provided a bulk density estimate from whole-round sections. The MAD method on discrete samples provided a second, independent measure of bulk density, as well as dry density, grain density, water content, and porosity. MAD and GRA bulk density measurements display the same trends and are also similar in absolute values through the entire section (Fig. F29). In both Holes U1403A and U1403B, MAD bulk density values are lower $\left(\sim 0.05 \mathrm{~g} / \mathrm{cm}^{3}\right)$ than GRA bulk density from the top of the holes to $\sim 150$ mbsf. From $\sim 150$ mbsf to the bottom of the hole, which was cored with the $\mathrm{XCB}$, these two data sets are largely comparable in value. We speculate that the GRA densities are overestimated because of a calibration problem. Generally, changes in bulk density correspond to changes in lithology. Bulk density is $\sim 1.5 \mathrm{~g} / \mathrm{cm}^{3}$ immediately below the seafloor in the nannofossil ooze with clay and varies between 1.3 and $1.65 \mathrm{~g} / \mathrm{cm}^{3}$ through lithostratigraphic Units I, II, and III (see "Lithostratigraphy"). A slight step toward lower values $\left(1.2 \mathrm{~g} / \mathrm{cm}^{3}\right)$ between 120 and 145 mbsf corresponds to the appearance of nannofossil ooze (Unit IV). The transition between Units IV and V at $\sim 150$ mbsf correlates with an increase in carbonate content (see "Geochemistry") and bulk density in the middle of Unit IV. Wet bulk density in the upper half of Unit V (155-210 mbsf) is relatively uniform, with low-amplitude variations around $\sim 1.60 \mathrm{~g} / \mathrm{cm}^{3}$, whereas the lower half of the unit is marked by an increase to $2.0 \mathrm{~g} / \mathrm{cm}^{3}$.

Porosity averages $70 \mathrm{vol} \%$ in Units I, II, and III, increases to $85 \mathrm{vol} \%$ in Unit IV, decreases to $60 \mathrm{vol} \%$ at the bottom of Unit IV, and further decreases to 45 vol\% in Unit V (Fig. F29).

Variations in grain density in Hole U1403A generally match changes in lithology (Fig. F29). In clay-rich sediment of Units I and II (see "Lithostratigraphy"), grain density is highly variable with values ranging from 2.15 to $2.8 \mathrm{~g} / \mathrm{cm}^{3}$. In other lithostratigraphic units, grain density averages $2.65 \mathrm{~g} / \mathrm{cm}^{3}$ and reaches $2.8 \mathrm{~g} / \mathrm{cm}^{3}$ in the lower part of Unit V.

\section{$P$-wave velocity}

$P$-wave data from whole-round sections and sectionhalves follow similar trends in Holes U1403A and U1403B and are consistent with one another; however, $P$-wave caliper (PWC) values are slightly lower than those obtained by the $P$-wave logger (PWL) (Fig. F30). All $P$-wave velocity data sets show a gradual in- crease $(1500-1600 \mathrm{~m} / \mathrm{s})$ with depth from lithostratigraphic Unit I to the ETM2 ( 160 mbsf) at the top of Unit V. Below this depth, data from the PWL are not available because the XCB-cored sediment did not fill the core liner fully. In Unit V, PWC data are variable $(1530-1750 \mathrm{~m} / \mathrm{s})$ with an overall average of $1600 \mathrm{~m} / \mathrm{s}$.

\section{Natural gamma radiation}

The general trends in NGR in both holes are similar to those seen in the bulk density data (Fig. F30). In lithostratigraphic Unit II, NGR averages $30 \mathrm{cps}$, falls to $20 \mathrm{cps}$ at the top of Unit III ( 70 mbsf), and rises to 35 cps at $\sim 110$ mbsf. Unit IV is characterized by NGR values of $\sim 15 \mathrm{cps}$, which correlate with the increase in carbonate content (see "Geochemistry"). NGR data in Unit $\mathrm{V}$ show more variation than in Units III and IV and have an average value of 25 cps.

\section{Color reflectance}

Trends in $\mathrm{a}^{*}$ and $\mathrm{b}^{*}$ are similar to one another and reflect changes in lithology (Fig. F31). In lithostratigraphic Unit I and in the uppermost half of Unit II, both reflectance parameters decrease (from 10 to -5 for $\mathrm{a}^{*}$ and from 30 to 4 for $\left.\mathrm{b}^{\star}\right)$. This decrease is followed by an increase downhole to the bottom of Unit II $\left(\mathrm{a}^{*}=\sim 10, \mathrm{~b}^{*}=\sim 25\right)$. In Unit III, $\mathrm{a}^{*}$ and $\mathrm{b}^{*}$ decrease downhole (from 4 to -3 for $\mathrm{a}^{*}$ and from 16 to 5 for $\left.\mathrm{b}^{*}\right)$. At $125 \mathrm{mbsf}$, both parameters rapidly increase in the interval where carbonate content increases (see "Geochemistry"). Variations in $\mathrm{a}^{*}$ and $\mathrm{b}^{*}$ co-vary with changes in magnetic susceptibility throughout the hole, and at $\sim 170$ mbsf, both parameters drop to minimum values. The bottom of Unit $\mathrm{V}$ is marked by high variability in spectral reflectance (from -10 to 20 for $\mathrm{a}^{*}$ and from 0 to 30 for $\mathrm{b}^{\star}$ ).

$\mathrm{L}^{*}$ corresponds to lightness and follows pronounced lithologic changes (Fig. F31). In general, $L^{*}$ follows similar trends in both holes at Site U1403, varying between 45 and 65 . The main variations occur within Unit II, in which $\mathrm{L}^{*}$ drops to local minima (25) at 35 mbsf and 52 mbsf, corresponding to dark brown sediments, and at the bottom of Unit IV and throughout Unit $\mathrm{V}$, where $\mathrm{L}^{*}$ varies between 15 and 70 .

\section{Stratigraphic correlation}

\section{Sampling splice}

We constructed a sampling splice for Site U1403 using shipboard physical property data that is continuous from 0 to $\sim 160 \mathrm{~m}$ core composite depth below seafloor (CCSF) and consists of a series of floating splices from $\sim 169$ to $274 \mathrm{~m}$ CCSF. The splice is based 
on GRA bulk density data in the upper 160 m CCSF, where magnetic susceptibility is low, and on WRMSL magnetic susceptibility from $\sim 160$ to $\sim 274$ m CCSF. As a result of more ambiguous physical property data in the upper $\sim 160 \mathrm{~m} \mathrm{CCSF}$, a number of tie points have been tentatively placed where features in the physical properties are inconclusive or the overlap between successive cores is small. Below $\sim 160 \mathrm{~m}$ CCSF, several intervals were not recovered in either Hole U1403A or U1403B as a result of the presence of chert. Hole U1403B spans the thickest sediment column recovered at this site, with a maximum depth for the bottom of Core 342-U1403B-32X of $255.40 \mathrm{mbsf}$ (290.23 m CCSF). Hole U1403A extends to 233.9 mbsf (262.69 m CCSF). As a result, we append the last two cores from Hole U1403B at the bottom of the splice. Our correlation yields a growth rate of $10 \%$ in CCSF relative to mbsf depth for Hole U1403A and 13\% for Hole U1403B Site U1403 (Fig. F32). The affine table (Table T23) summarizes the individual offsets for each core drilled.

\section{Correlation during drilling operations}

In order to provide real-time assessment of the composite section to monitor and direct drilling, we collected magnetic susceptibility and GRA bulk density data at $2.5 \mathrm{~cm}$ resolution on the Special Task Multisensor Logger) soon after recovery (before allowing cores to equilibrate to room temperature). We added preliminary depth shifts to cores from both holes on the basis of these data. Despite good weather conditions and minimal tides $(<0.8 \mathrm{~m})$, an inconsistency in the apparent seafloor depth between the two holes led to the inadvertent alignment of core gaps between Holes U1403A and U1403B. Our attempts to achieve overlap resulted in an apparent double recovery of the same interval between Cores 342$\mathrm{U} 1403 \mathrm{~B}-2 \mathrm{H}$ and $3 \mathrm{H}$ and between Cores $3 \mathrm{H}$ and $4 \mathrm{H}$. The doubling of recovered sequences is evident through comparison of intervals 342-U1403B-2H-6, $25 \mathrm{~cm}$, and $3 \mathrm{H}-1,20 \mathrm{~cm}$, in the core photographs.

Following early corrections, we were able to maintain a relatively constant offset between each hole downhole to the chert layer at $\sim 160 \mathrm{~m} \mathrm{CCSF}$. We consider the gap between $\sim 160$ and $\sim 169$ m CCSF to be unbridgeable because of the presence of chert. Intervening chert intervals from $\sim 160 \mathrm{~m}$ CCSF to the bottom of Hole U1403A at 274 m CCSF prevented the offset of all coring gaps, but a series of prominent features in physical properties allowed reliable correlation (especially across the end of ETM2 to the PETM in Cores 342-U1403B-19H to 342-U1403A$21 \mathrm{X}$ and the K/Pg boundary in Cores 342-U1403A26X and 342-U1403B-28X).

\section{Correlation and splice construction}

Stratigraphic correlation and splice construction were based on WRMSL magnetic susceptibility and GRA density data collected after equilibration on cores from both holes. We also assessed color reflectance data available from the SHMSL, NGR data, core photographs (see "Physical properties"), and paleomagnetism reversal data (see "Paleomagnetism"). Magnetic susceptibility is low ( $<50 \mathrm{IU})$ from $\sim 10$ to $160 \mathrm{~m}$ CCSF, and a few intervals show very low magnetic susceptibility (<15 IU) (e.g., 15-18 and 23-38 $\mathrm{m}$ CCSF) (Fig. F33). As a result, GRA density data generally proved most useful for the correlation of the upper $\sim 160$ m CCSF, whereas magnetic susceptibility proved most useful for correlating below this depth. The majority of tentative ties in the splice occur in the interval of lowest magnetic susceptibility, from 25-140 m CCSF.

Table T24 lists sections of core used for the splice. We defined the mudline (where 0 mbsf equals $0 \mathrm{~m}$ CCSF) of Site U1403 at the top of Core 342-U1403B$1 \mathrm{H}$. Although Core 342-U1403A-1H seemed to recover a clear mudline, the drill floor reported that the drill string had touched the seabed prior to the first firing of the piston. Therefore, we could not rule out a possible doubling of recovered material in Core 342-U1403A-1H, making Hole U1403A less suitable for defining the mudline. Using Core 342-U1403B$1 \mathrm{H}$ for the mudline definition yields negative CCSF depths for the top of Core 342-U1403A-1H.

A tentative tie occurs between Cores 342-U1403B$19 \mathrm{H}$ and $20 \mathrm{H}$ at $\sim 173 \mathrm{~m} \mathrm{CCSF}$, where it appears that the same interval was recovered by each core. The intervals 342-U1403B-19H-4, $15 \mathrm{~cm}$, and 20H-1, 10 $\mathrm{cm}$, show the same clear dark brown to light yellow transition visible in core line scan images. Without an obvious tie between Cores 342-U1403A-19X and 342-U1403B-19H, we chose to tie Cores 342$\mathrm{U} 1403 \mathrm{~B}-19 \mathrm{H}$ and $20 \mathrm{H}$ in the splice in order to achieve a continuous record of the ETM2. However, this tie point is tentative given the unusual practice of selecting a tie point from two cores in the same hole.

We applied a large offset $(5.86 \mathrm{~m})$ to Core 342U1403A-22X, which advanced $9.7 \mathrm{~m}$ yet only recovered $\sim 3 \mathrm{~m}$ of sediment, and we correlated Core 342U1403A-22X to Core 342-U1403B-24X on the basis of magnetic susceptibility. We applied another large offset $(4.06 \mathrm{~m})$ to the top of Core 342-U1403A-26X, where despite a nominal advance of $4.8 \mathrm{~m}$ during the drilling of Core $25 \mathrm{X}, 8.65 \mathrm{~m}$ of core was recovered, so that the bottom of Core $25 \mathrm{X}$ had an mbsf depth of almost $4 \mathrm{~m}$ greater than the mbsf depth for the top of Core 26X. However, the physical property data of Cores 25X and 26X do not visually resemble 
each other, suggesting no overlap occurred. We added an offset to Core $26 \mathrm{X}$ such that there is no overlap with Core 25X (Fig. F32). Unfortunately, this gap was not bridged in Hole U1403B.

The Site U1403 splice can be used as a sampling guide to recover a single sedimentary sequence, though it is advisable to overlap splice intervals at the ties by a few decimeters when sampling to accommodate anticipated ongoing development of the depth scale. Although we did not stretch or compress cores in our splice, clear distortion of sedimentary features (especially at the top and bottom of cores) indicates additional adjustment is warranted. Much of the distortion occurs within individual cores, particularly XCB cores, so it was not possible to align every single feature in the magnetic susceptibility, GRA density, NGR, and color reflectance records. For instance, there is a strong tie between Cores 342U1403A-19X and 342-U1403B-20H, but the top of Core 342-U1403A-19X is clearly compressed, such that not all features between the overlapping intervals from each hole align (Fig. F34). The distortion in Hole U1403A in this interval is probably a result of $\mathrm{XCB}$ drilling compared to the APC recovery in Hole U1403B. Given the number of significant events recovered at Site U1403, we took care to avoid the use of event beds as tie points, so that these can be sampled in one section.

\section{References}

Arthur, M.A., 1979. Origin of Upper Cretaceous multicolored claystones of the Western Atlantic. In Tucholke, B.E., Vogt, P.R., et al., Init. Repts. DSDP, 43: Washington, DC (U.S. Govt. Printing Office), 417-420. doi:10.2973/ dsdp.proc.43.111.1979

Baker, P.A., Gieskes, J.M., and Elderfield, H., 1982. Diagenesis of carbonates in deep-sea sediments: evidence from $\mathrm{Sr} / \mathrm{Ca}$ ratios and interstitial dissolved $\mathrm{Sr}^{2+}$ data. J. Sediment. Petrol., 52(1):71-82. doi:10.1306/?212F7EE12B24-11D7-8648000102C1865D

Coccioni, R., Frontalini, F., and Spezzaferri, S., 2009. Late Eocene impact-induced climate and hydrological changes: evidence from the Massignano global stratotype section and point (central Italy). Spec. Pap.-Geol. Soc. Am., 452:97-118. doi:10.1130/2009.2452(07)

Dickens, G.R., Castillo, M.M., and Walker, J.C.G., 1997. A blast of gas in the latest Paleocene: simulating firstorder effects of massive dissociation of oceanic methane hydrate. Geology, 25(3):259-262. doi:10.1130/00917613(1997)025<0259:ABOGIT>2.3.CO;2

Gieskes, J.M., 1981. Deep-sea drilling interstitial water studies: implications for chemical alteration of the oceanic crust, Layers I and II. In Warme, J.E., Douglas, R.G., and Winterer, E.L. (Eds.), The Deep Sea Drilling Project: A Decade of Progress. Spec. Publ.-Soc. Econ. Paleontol. Mineral., 32:149-167.
Gradstein, F.M., Ogg, J.G., Schmitz, M.D., and Ogg, G.M. (Eds)., 2012. The Geological Time Scale 2012: Amsterdam (Elsevier).

Hollis, C.J., Dickens, G.R., Field, B.D., Jones, C.M., and Strong, C.P., 2005. The Paleocene-Eocene transition at Mead Stream, New Zealand: a southern Pacific record of early Cenozoic global change. Palaeogeogr., Palaeoclimatol., Palaeoecol., 215(3-4):313-343. doi:10.1016/j.palaeo.2004.09.011

Kelly, D.C., Nielsen, T.M.J., McCarren, H.K., Zachos, J.C., and Röhl, U., 2010. Spatiotemporal patterns of carbonate sedimentation in the South Atlantic: implications for carbon cycling during the Paleocene-Eocene Thermal Maximum. Palaeogeogr., Palaeoclimatol., Palaeoecol., 293(1-2):30-40. doi:10.1016/j.palaeo.2010.04.027

Kirschvink, J.L., 1980. The least-squares line and plane and the analysis of palaeomagnetic data. Geophys. J. R. Astron. Soc., 62(3):699-718. doi:10.1111/j.1365246X.1980.tb02601.x

Lees, J.A., and Bown, P.R., 2005. Upper Cretaceous calcareous nannofossil biostratigraphy, ODP Leg 198 (Shatsky Rise, northwest Pacific Ocean). In Bralower, T.J., Premoli Silva, I., and Malone, M.J. (Eds.), Proc. ODP, Sci. Results, 198: College Station, TX (Ocean Drilling Program), 160. doi:10.2973/odp.proc.sr.198.114.2005

Lyle, M., Wilson, P.A., Janecek, T.R., et al., 2002. Proc. ODP, Init. Repts., 199: College Station, TX (Ocean Drilling Program). doi:10.2973/odp.proc.ir.199.2002

Merico, A., Tyrrell, T., and Wilson, P.A., 2008. Eocene/Oligocene ocean de-acidification linked to Antarctic glaciation by sea-level fall. Nature (London, U. K.), 452(7190):979-982. doi:10.1038/nature06853

Norris, R.D., Klaus, A., and Kroon, D., 2001. Mid-Eocene deep water, the Late Palaeocene Thermal Maximum and continental slope mass wasting during the CretaceousPalaeogene impact. In Kroon, D., Norris, R.D., and Klaus, A. (Eds.), Western North Atlantic Paleogene and Cretaceous Paleoceanography. Geol. Soc. Spec. Publ., 183(1):23-48. doi:10.1144/GSL.SP.2001.183.01.02

Norris, R.D., Wilson, P.A., Blum, P., Fehr, A., Agnini, C., Bornemann, A., Boulila, S., Bown, P.R., Cournede, C., Friedrich, O., Ghosh, A.K., Hollis, C.J., Hull, P.M., Jo, K., Junium, C.K., Kaneko, M., Liebrand, D., Lippert, P.C., Liu, Z., Matsui, H., Moriya, K., Nishi, H., Opdyke, B.N., Penman, D., Romans, B., Scher, H.D., Sexton, P., Takagi, H., Turner, S.K., Whiteside, J.H., Yamaguchi, T., and Yamamoto, Y., 2014a. Expedition 342 summary. In Norris, R.D., Wilson, P.A., Blum, P., and the Expedition 342 Scientists, Proc. IODP, 342: College Station, TX (Integrated Ocean Drilling Program). doi:10.2204/ iodp.proc.342.101.2014

Norris, R.D., Wilson, P.A., Blum, P., Fehr, A., Agnini, C., Bornemann, A., Boulila, S., Bown, P.R., Cournede, C., Friedrich, O., Ghosh, A.K., Hollis, C.J., Hull, P.M., Jo, K., Junium, C.K., Kaneko, M., Liebrand, D., Lippert, P.C., Liu, Z., Matsui, H., Moriya, K., Nishi, H., Opdyke, B.N., Penman, D., Romans, B., Scher, H.D., Sexton, P., Takagi, H., Turner, S.K., Whiteside, J.H., Yamaguchi, T., and Yamamoto, Y., 2014b. Methods. In Norris, R.D., Wilson, P.A., Blum, P., and the Expedition 342 Scientists, Proc. 
IODP, 342: College Station, TX (Integrated Ocean Drilling Program). doi:10.2204/

iodp.proc.342.102.2014

Pälike, H., Lyle, M.W., Nishi, H., Raffi, I., Ridgwell, A., Gamage, K., Klaus, A., Acton, G., Anderson, L., Backman, J., Baldauf, J., Beltran, C., Bohaty, S.M., Bown, P., Busch, W., Channell, J.E.T., Chun, C.O.J., Delaney, M., Dewangan, P., Dunkley Jones, T., Edgar, K.M., Evans, H., Fitch, P., Foster, G,L., Gussone, N., Hasegawa, H., Hathorne, E.C., Hayashi, H., Herrle, J.O., Holbourn, A., Hovan, S., Hyeong, K., Iijima, K., Ito, T., Kamikuri, S., Kimoto, K., Kuroda, J., Leon-Rodriguez, L., Malinverno, A., Moore, T.C., Jr., Murphy, B.H., Murphy, D.P., Nakamura, H., Ogane, K., Ohneiser, C., Richter, C., Robinson, R., Rohling, E.J., Romero, O., Sawada, K., Scher, H., Schneider, L., Sluijs, A., Takata, H., Tian, J., Tsujimoto, A., Wade, B.S., Westerhold, T., Wilkens, R., Williams, T., Wilson, P.A., Yamamoto, Y., Yamamoto, S., Yamazaki, T., and Zeebe, R.E., 2012. A Cenozoic record of the equatorial Pacific carbonate compensation depth. Nature (London, U. K.), 488(7409):609-614. doi:10.1038/ nature 11360

Raffi, I., Backman, J., and Pälike, H., 2005. Changes in calcareous nannofossil assemblages across the Paleocene/ Eocene transition from the paleo-equatorial Pacific Ocean. Palaeogeogr., Palaecoclimatol., Palaeoecol., 226(12):93-126. doi:10.1016/j.palaeo.2005.05.006

Sanfilippo, A., and Blome, C.D., 2001. Biostratigraphic implications of mid-latitude Paleocene-Eocene radiolar- ian faunas from Hole 1051A, ODP Leg 171B, Blake Nose, western North Atlantic. In Kroon, D., Norris, R.D., and Klaus, A. (Eds.), Western North Atlantic Palaeogene and Cretaceous Palaeoceanography. Geol. Soc. Spec. Publ., 183(1):185-224. doi:10.1144/GSL.SP.2001.183.01.10

Tucholke, B.E., and Vogt, P.R., 1979. Western North Atlantic: sedimentary evolution and aspects of tectonic history. In Tucholke, B.E., Vogt, P.R., et al., Init. Repts. DSDP, 43: Washington, DC (U.S. Govt. Printing Office), 791825. doi:10.2973/dsdp.proc.43.140.1979

van Morkhoven, F.P.C.M., Berggren, W.A., and Edwards, A.S., 1986. Cenozoic Cosmopolitan Deep-Water Benthic Foraminifera. Bull. Cent. Rech. Explor.-Prod. Elf-Aquitaine, 11 .

Widmark, J.G.V., 1995. Multiple deep-water sources and trophic regimes in the latest Cretaceous deep sea: evidence from benthic foraminifera. Mar. Micropaleontol., 26(1-4):361-384. doi:10.1016/0377-8398(95)00005-4

Zachos, J.C., Röhl, U., Schellenberg, S.A., Sluijs, A., Hodell, D.A., Kelly, D.C., Thomas, E., Nicolo, M., Raffi, I., Lourens, L.J., McCarren, H., and Kroon, D., 2005. Rapid acidification of the ocean during the Paleocene-Eocene thermal maximum. Science, 308(5728):1611-1615. doi:10.1126/science.1109004

Publication: 3 March 2014 MS 342-104 
Figure F1. Bathymetric map of the southwestern end of J-Anomaly Ridge showing the location of Site U1403 (red star). Track lines are from a single-channel seismic survey conducted during the KNR179-1 site survey. See Figures F2 and F3 for seismic profiles.

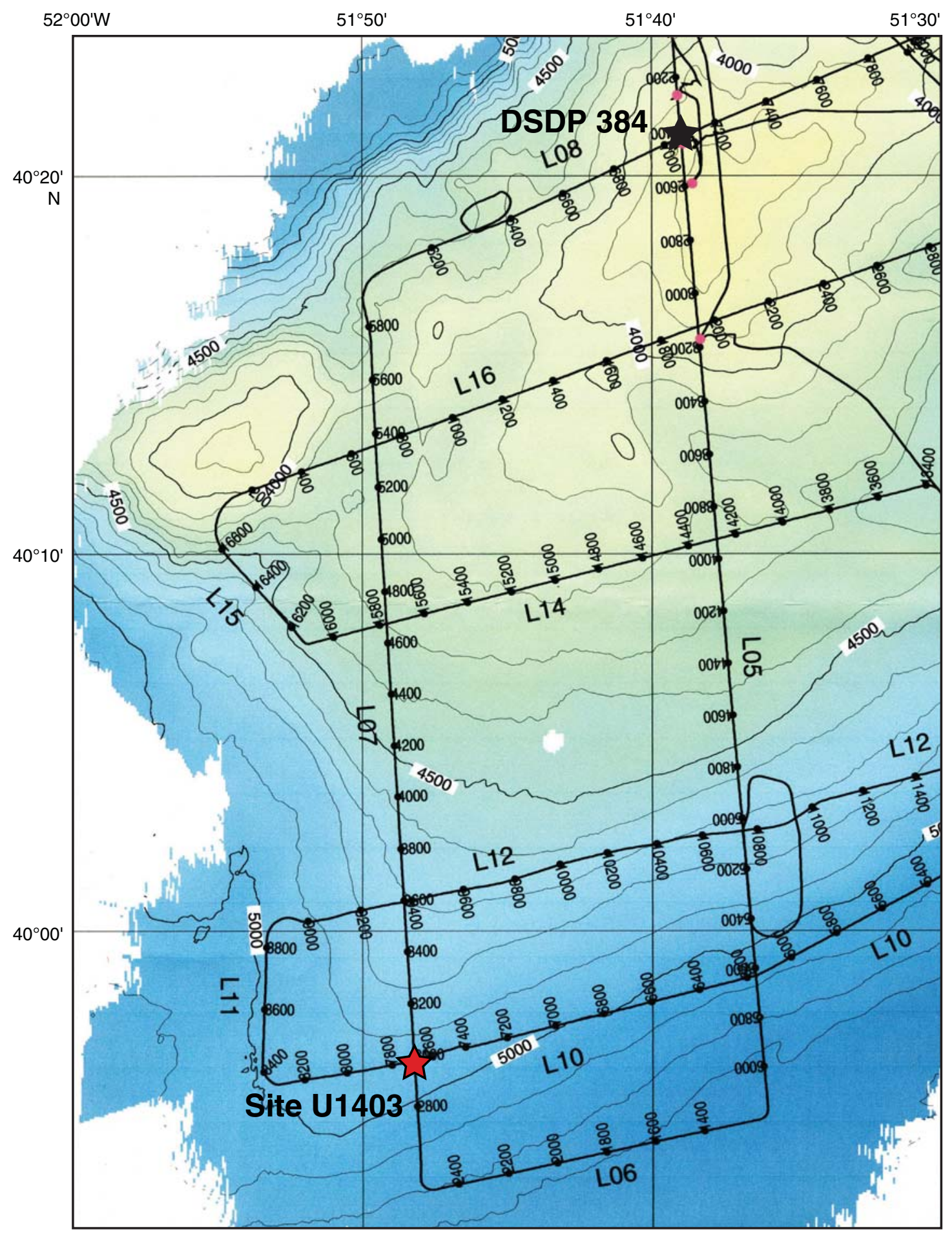


Figure F2. Single-channel seismic KNR179-1 Line 7north-south dip line crossing Site U1403 (at shotpoint [SP] 2990). White bar represents the depth of penetration ( $265.1 \mathrm{mbsf}$ ) using a $\sim 100 \mathrm{~m}$ per $0.1 \mathrm{~s}$ depth-to-time conversion. Identified acoustic horizons shown at the approximate locations of the early/middle Eocene boundary, the Paleocene/Eocene Thermal Maximum (PETM), and Cretaceous/Paleogene (K/Pg) boundary.

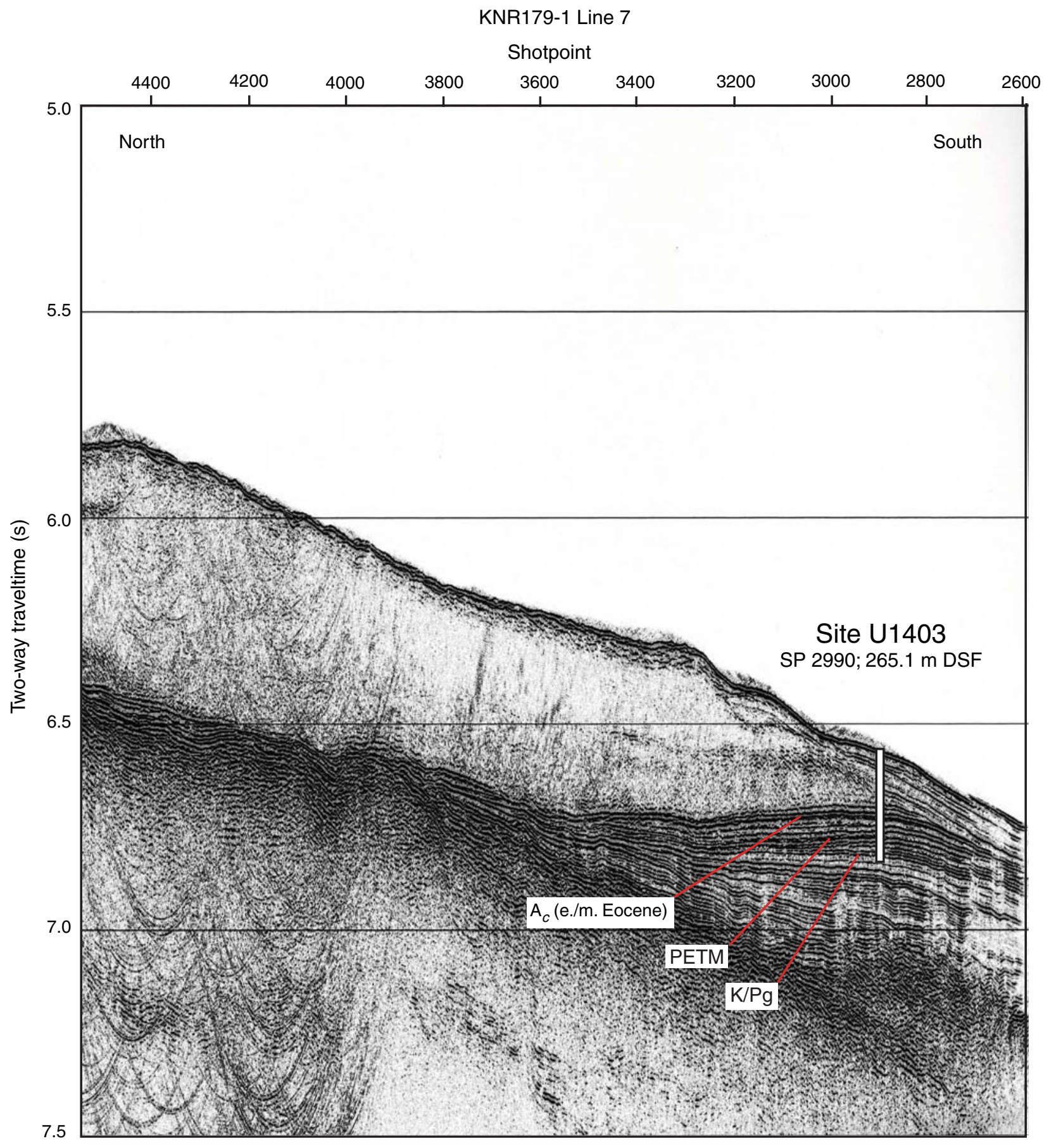


Figure F3. Single-channel seismic KNR179-1 Line 10. This is the northeast-southwest strike line crossing Site U1403 (at shotpoint [SP] 7700). White bar represents the depth of penetration (265.1 mbsf) using a $\sim 100 \mathrm{~m}$ per $0.1 \mathrm{~s}$ depth-to-time conversion. Identified acoustic horizons shown at the approximate locations of the early/ middle Eocene boundary, the Paleocene/Eocene Thermal Maximum (PETM), and Cretaceous/Paleogene (K/Pg) boundary.

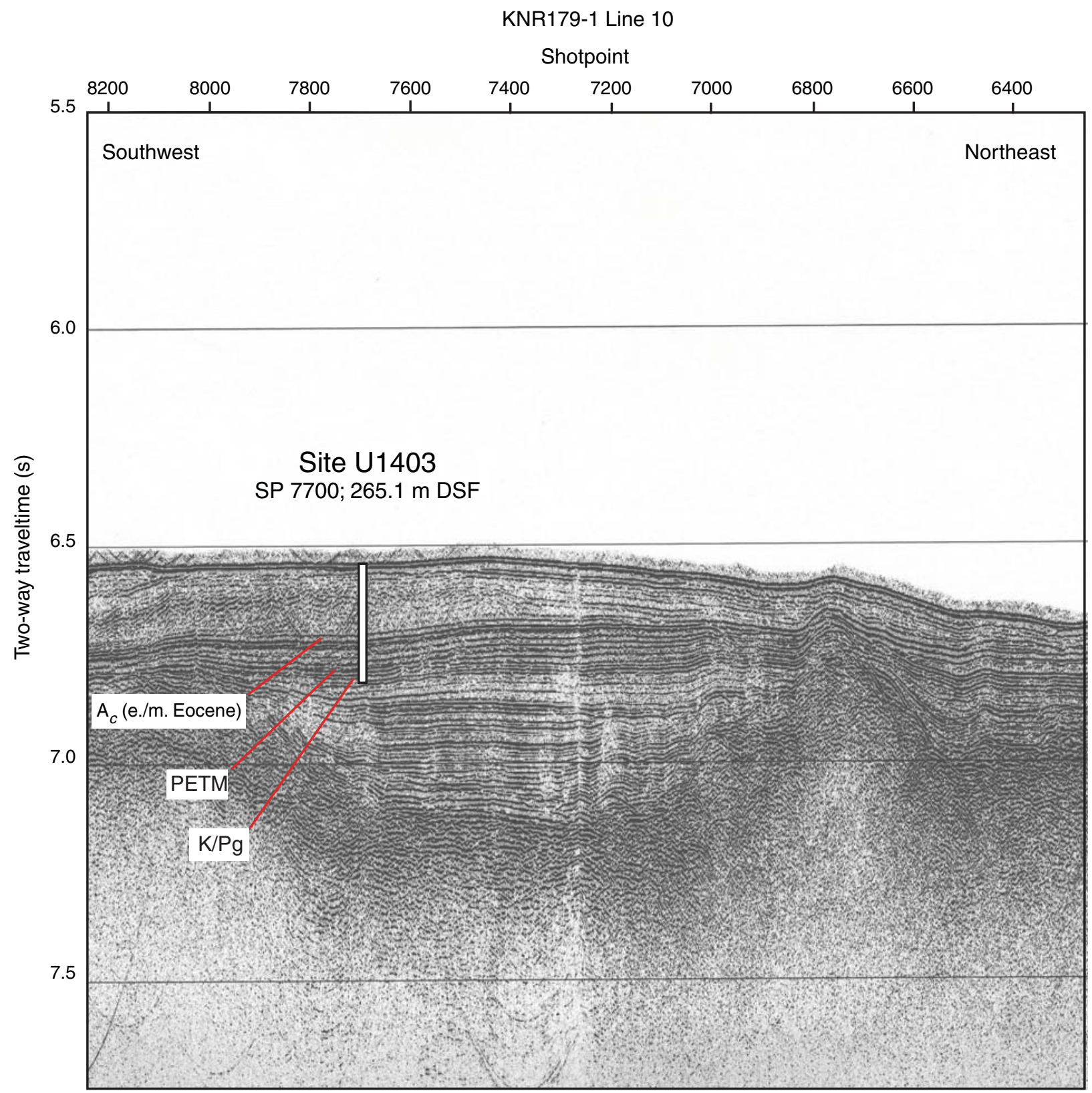


Figure F4. Lithostratigraphic summary, Site U1403. Hole U1403A is shown in the lithology and core photo composite with the exception of the bottom of the column, which was drilled deeper in Hole U1403B (Cores 342-U1403B-31X and 32X). Where the cores overlap, the columns are from Hole U1403A.

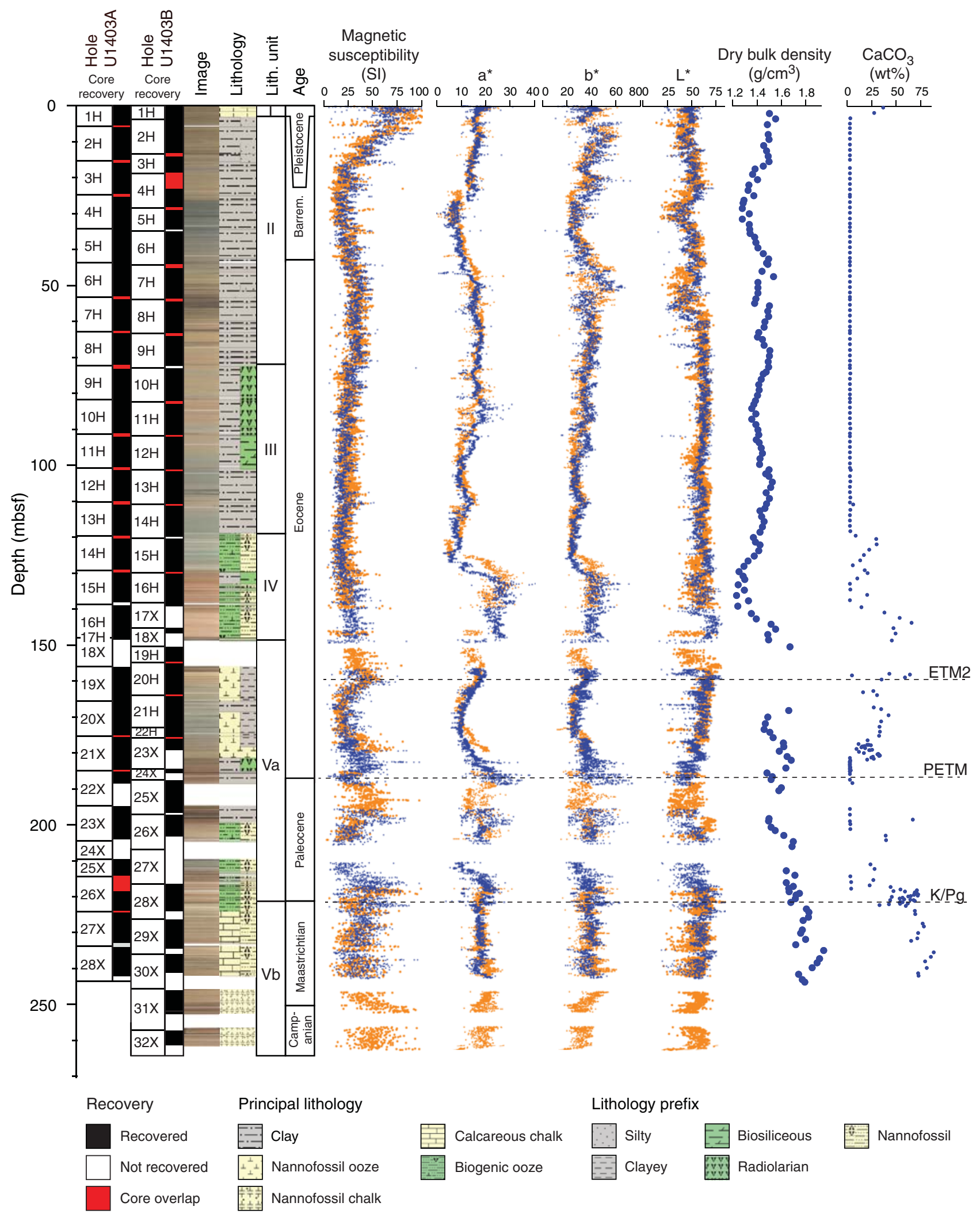


Figure F5. Line scan images from most common lithologies, Site U1403. A. Clay with silt, Unit II. B. Eocene clay with radiolarians, Unit III. C. Eocene nannofossil biogenic ooze with radiolarians, Unit IV. D. Paleocene nannofossil biogenic ooze, Subunit Va. E. Maastrichtian claystone, Subunit Vb. F. Maastrichtian nannofossil chalk, Subunit Vb.
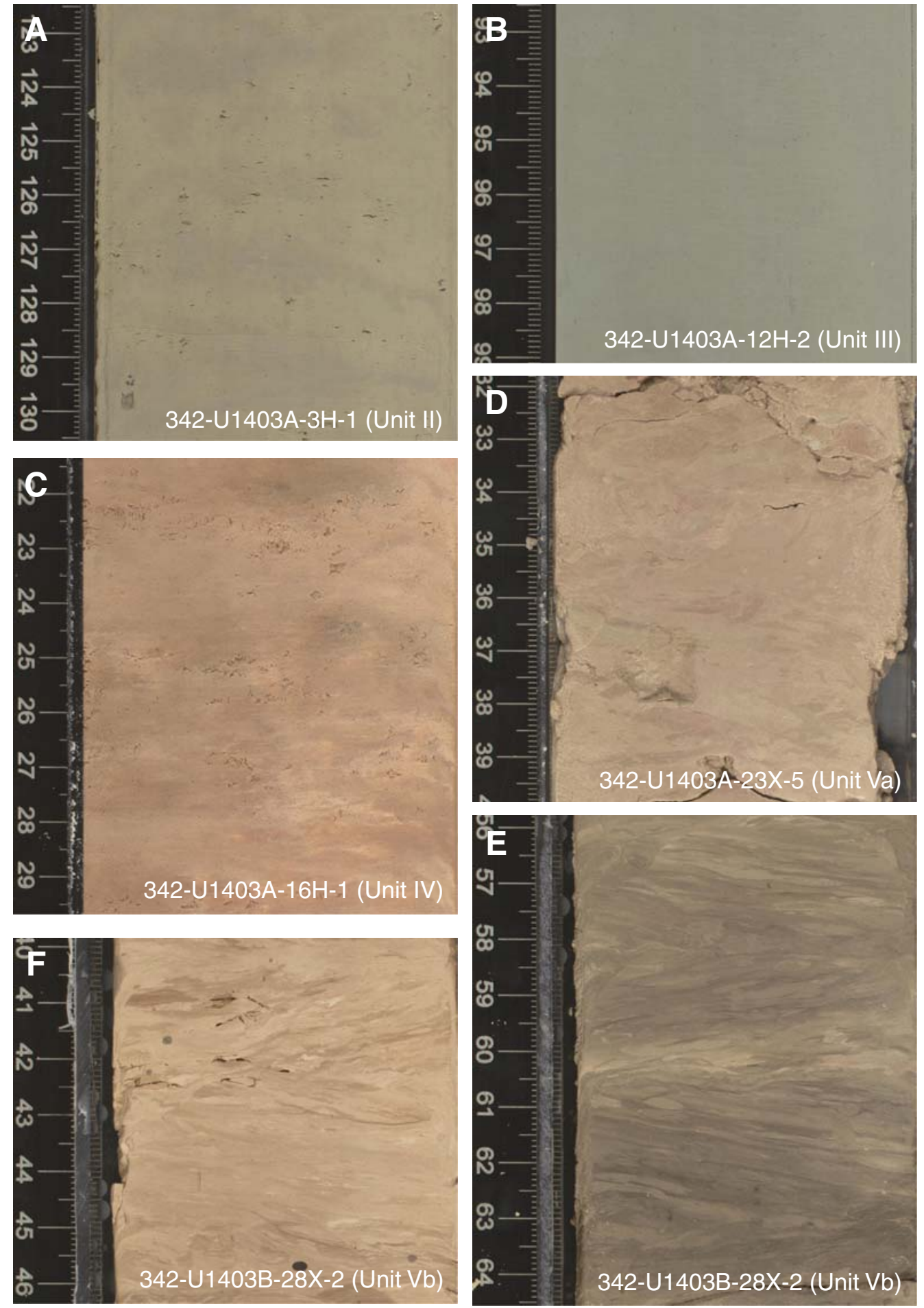
Figure F6. Photomicrographs of smear slides indicating the dominant lithologies of Units II-V, Site U1403. Note that prominent radiolarians in B under cross-polarized light are likely due to clay aggregates in their tests. A. Clay with zeolites, Unit II. B. Radiolarian clay, Unit III. C. Radiolarian nannofossil ooze, Unit IV. D. Foraminiferal nannofossil ooze, Subunit Va.
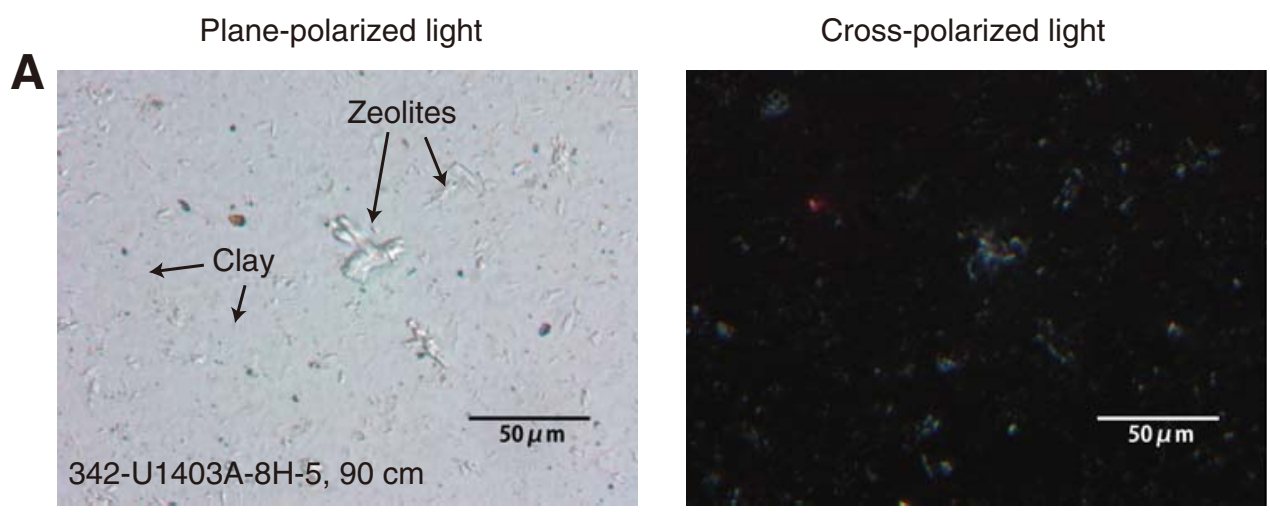

B
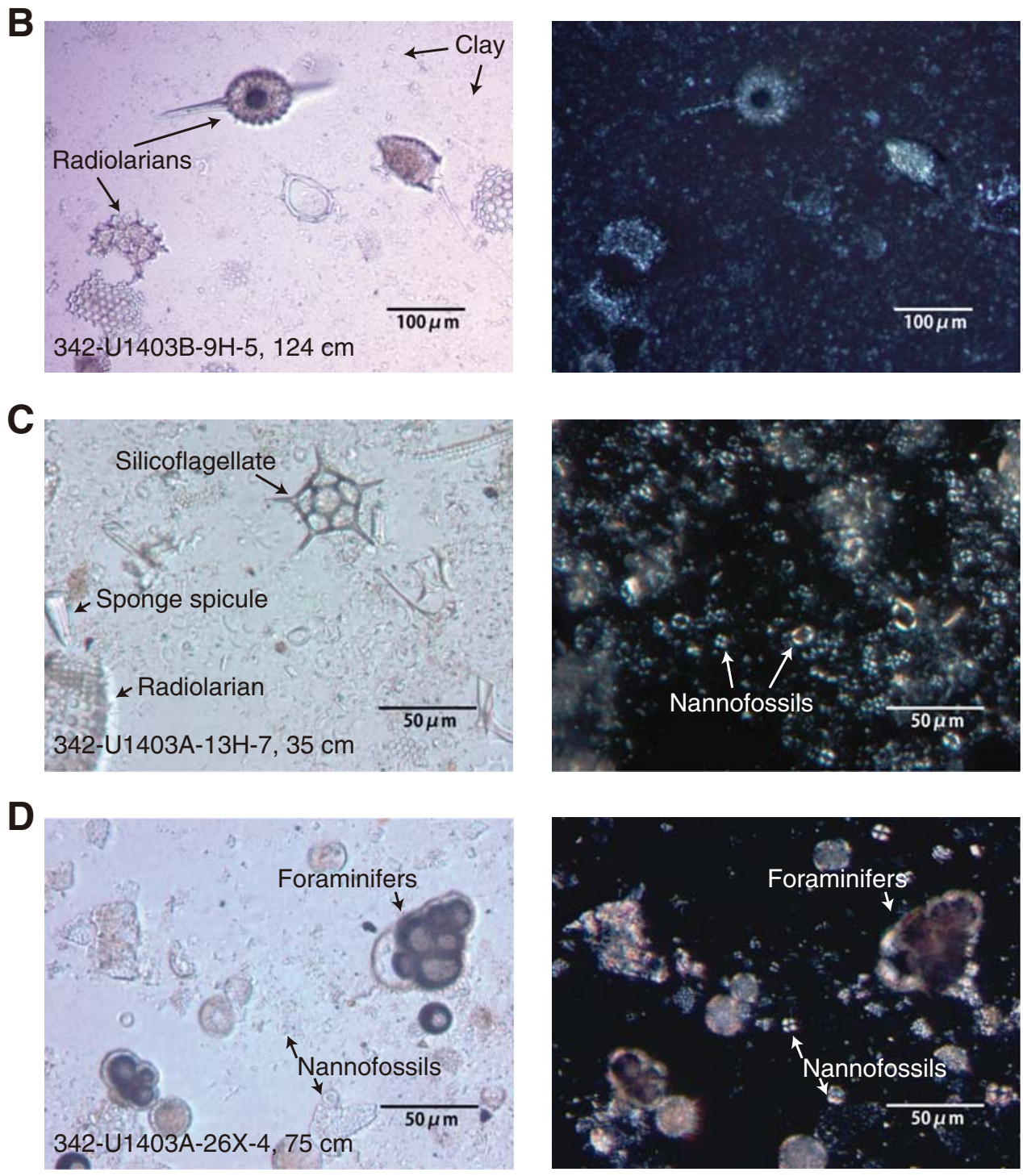
Figure F7. Plots of smear slide results of major biogenic and lithologic components and their relative abundance by depth, Site U1403. VA $=$ very abundant, $\mathrm{A}=$ abundant, $\mathrm{C}=$ common, $\mathrm{F}=$ few, $\mathrm{P}=$ present .

Hole U1403A

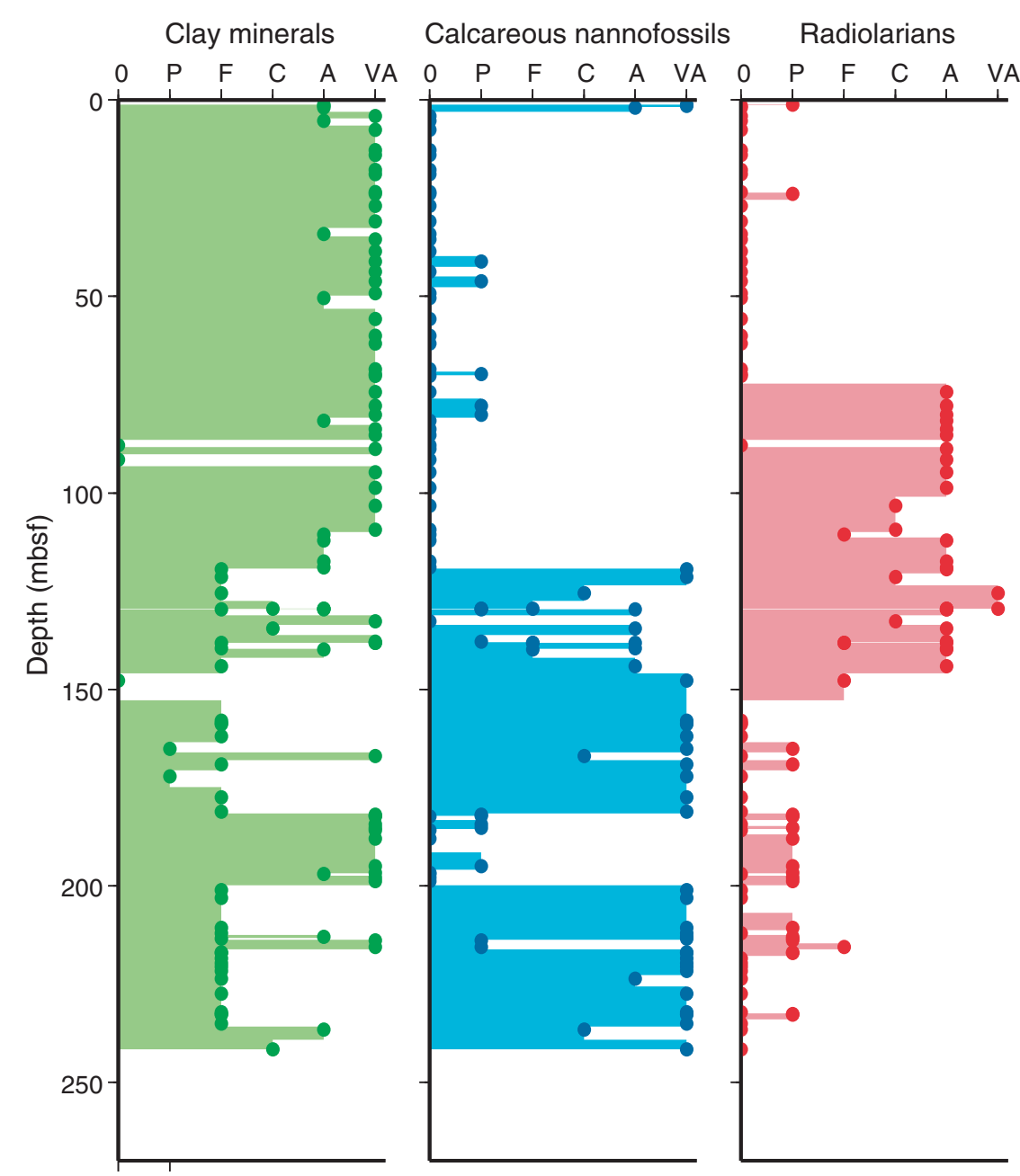

Hole U1403B

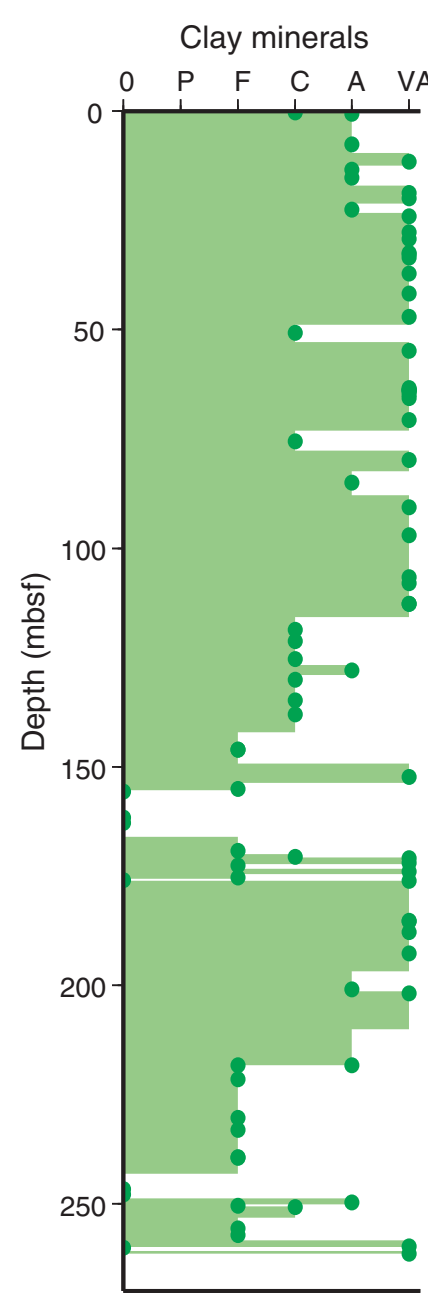

Calcareous nannofossils Radiolarians

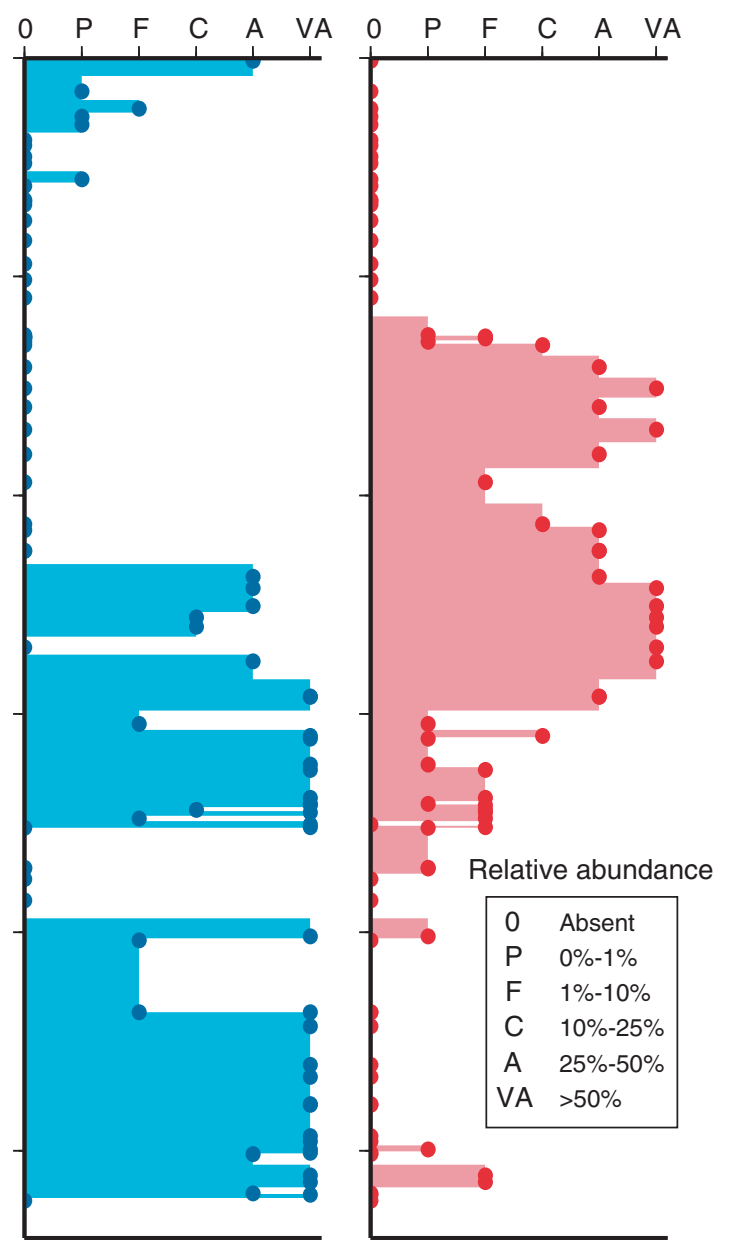


Figure F8. Photographs of manganese nodules, Section 342-U1403A-1H-2. A. Whole nodule. B. Internal view.

A

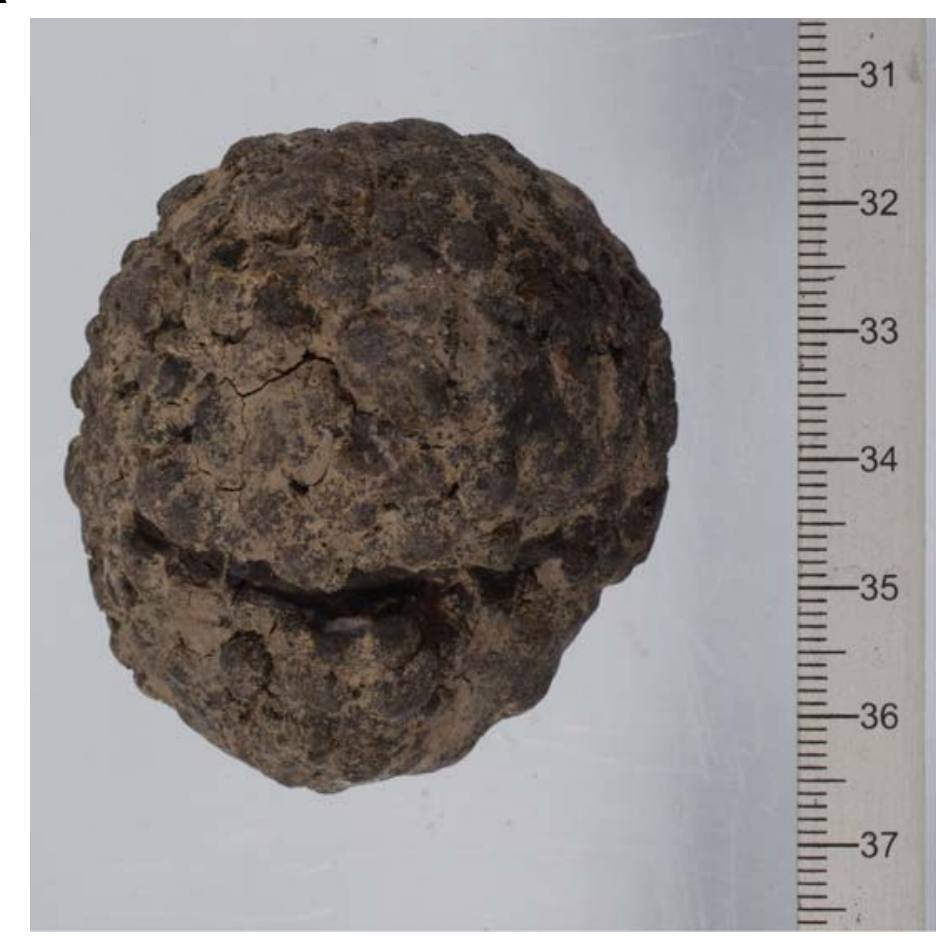

B 342-U1403A-1H-2A, 0-8 cm

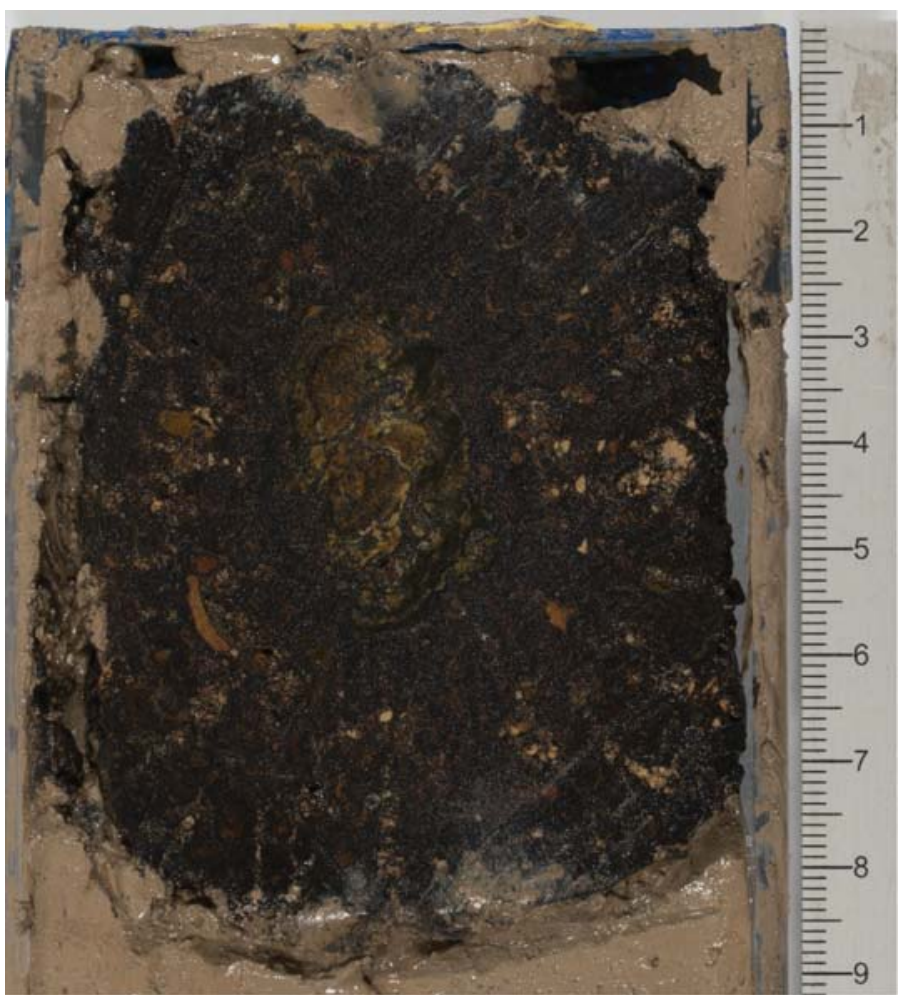


Figure F9. XRD spectrum of a pink micronodule from Unit III (133.48 mbsf), Hole U1403A. Inset is an image of a $4 \mathrm{~cm}$ thick interval $\sim 65 \mathrm{~cm}$ above the analyzed sample showing the typical pinkish sediment of Unit III (see text for details).

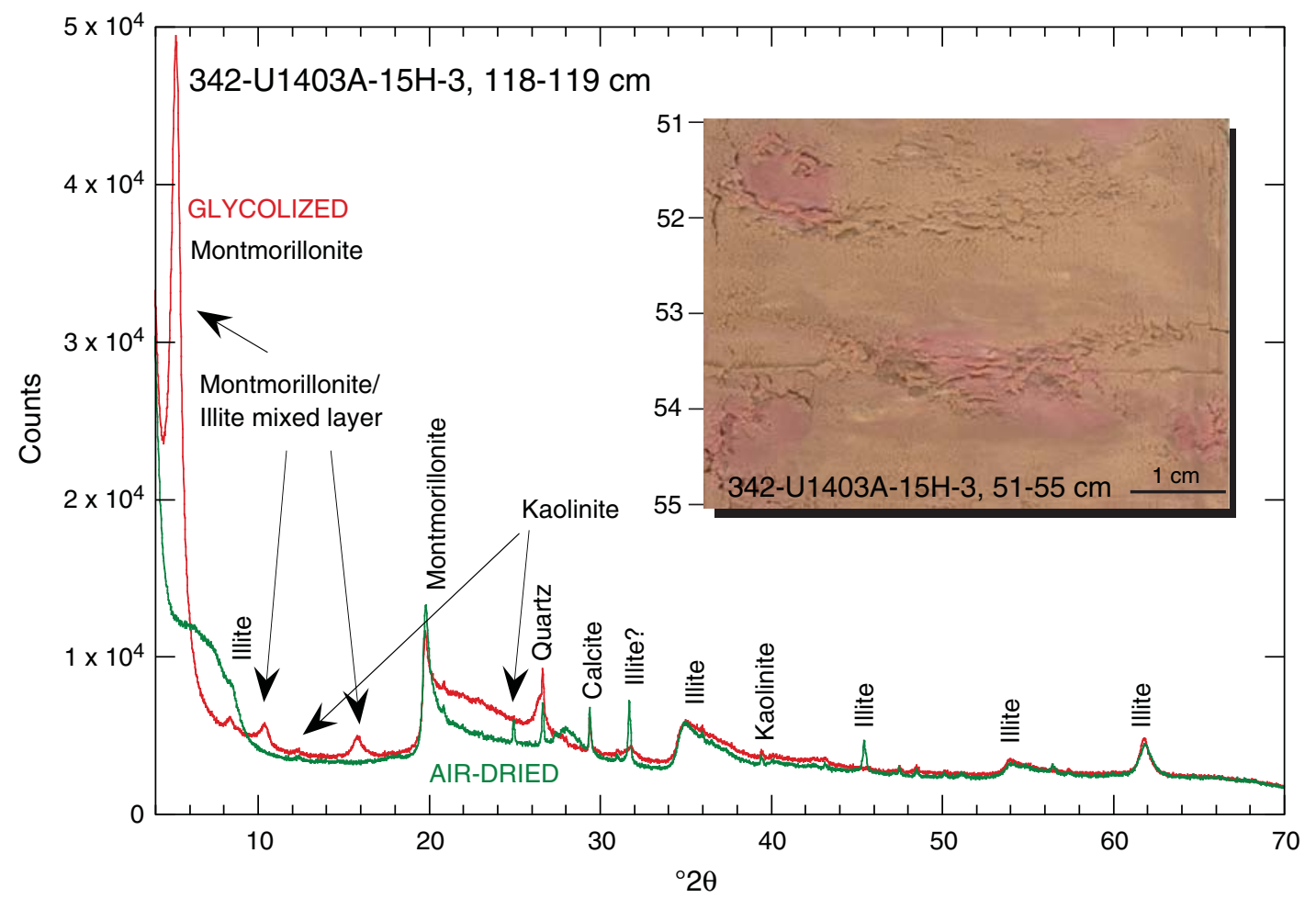


Figure F10. Core images and lithostratigraphic and biostratigraphic summary of the Cretaceous-Paleogene transition, Holes U1403A and U1403B. Note that section-half preparation (splitting and washing) in both holes resulted in downhole transport of the Cretaceous/Paleogene $(\mathrm{K} / \mathrm{Pg})$ boundary spherules and the loss of some boundary material in Hole U1403B.

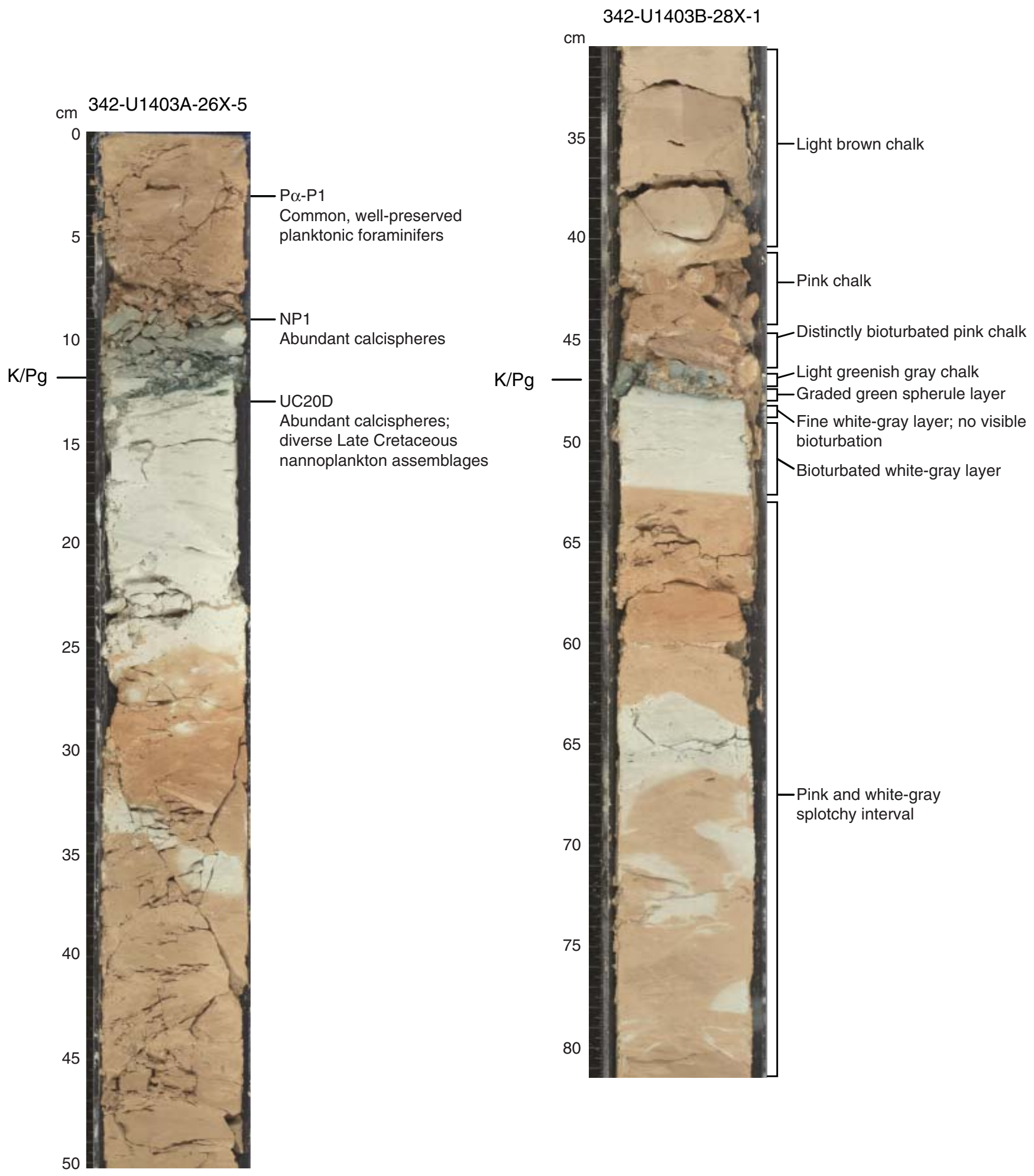


Figure F11. Close-up photographs of the Cretaceous/Paleogene (K/Pg) transition, Site U1403.

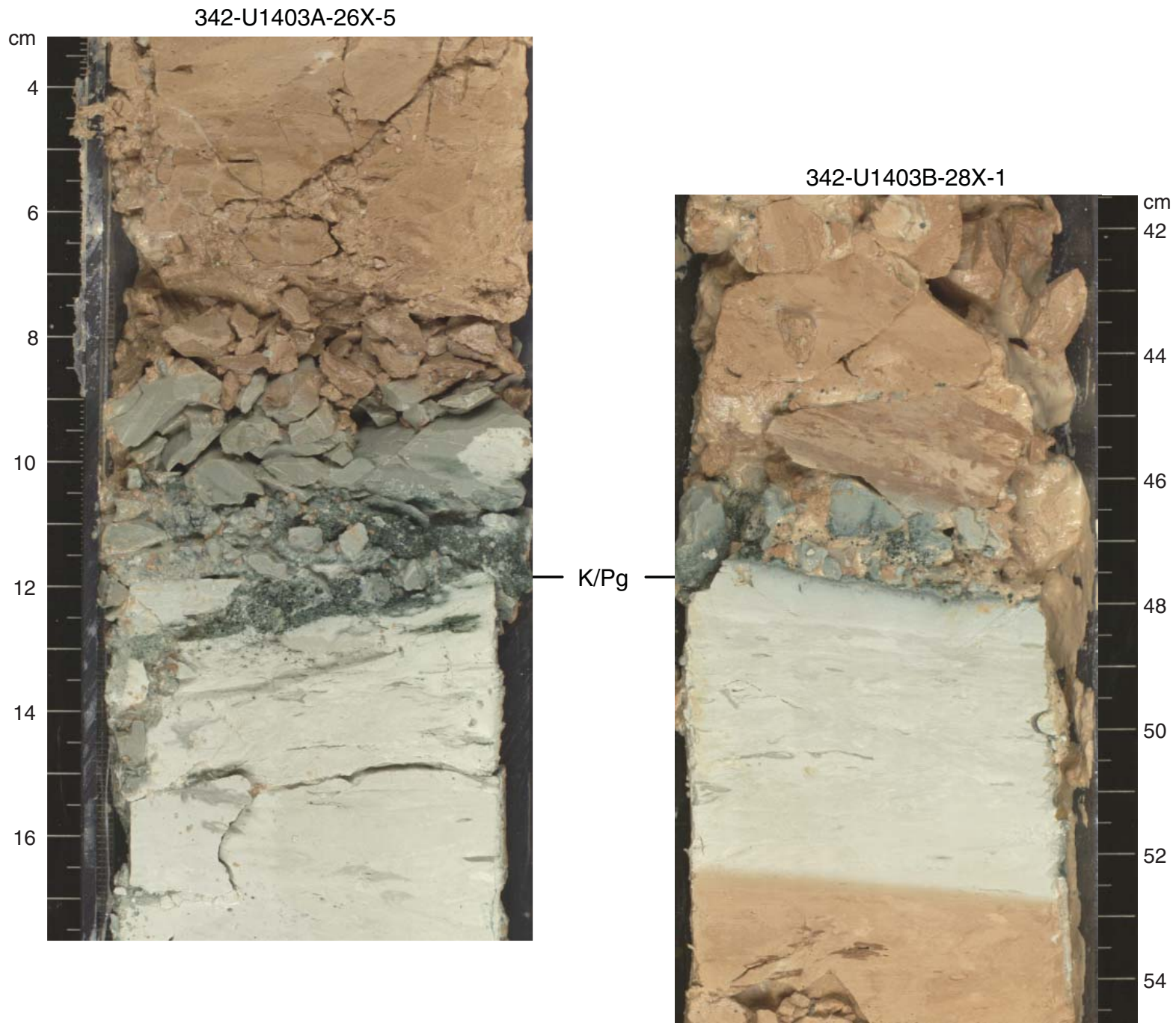


Figure F12. Core images and summary of the expression of the Paleocene/Eocene Thermal Maximum (PETM) spanning Cores 342-U1403A-21X and 22X. Magnetic susceptibility data from the Section Half Multisensor Logger (point measurements; red) and Whole-Round Multisensor Logger (blue). The break in magnetic susceptibility at $185.5 \mathrm{mbsf}$ is the short core catcher of Core $21 \mathrm{X}$. Biostratigraphic ranges of nannofossil and radiolarian excursion taxa are based on coarsely sampled, discrete paleontological samples and should therefore be considered minimum ranges.

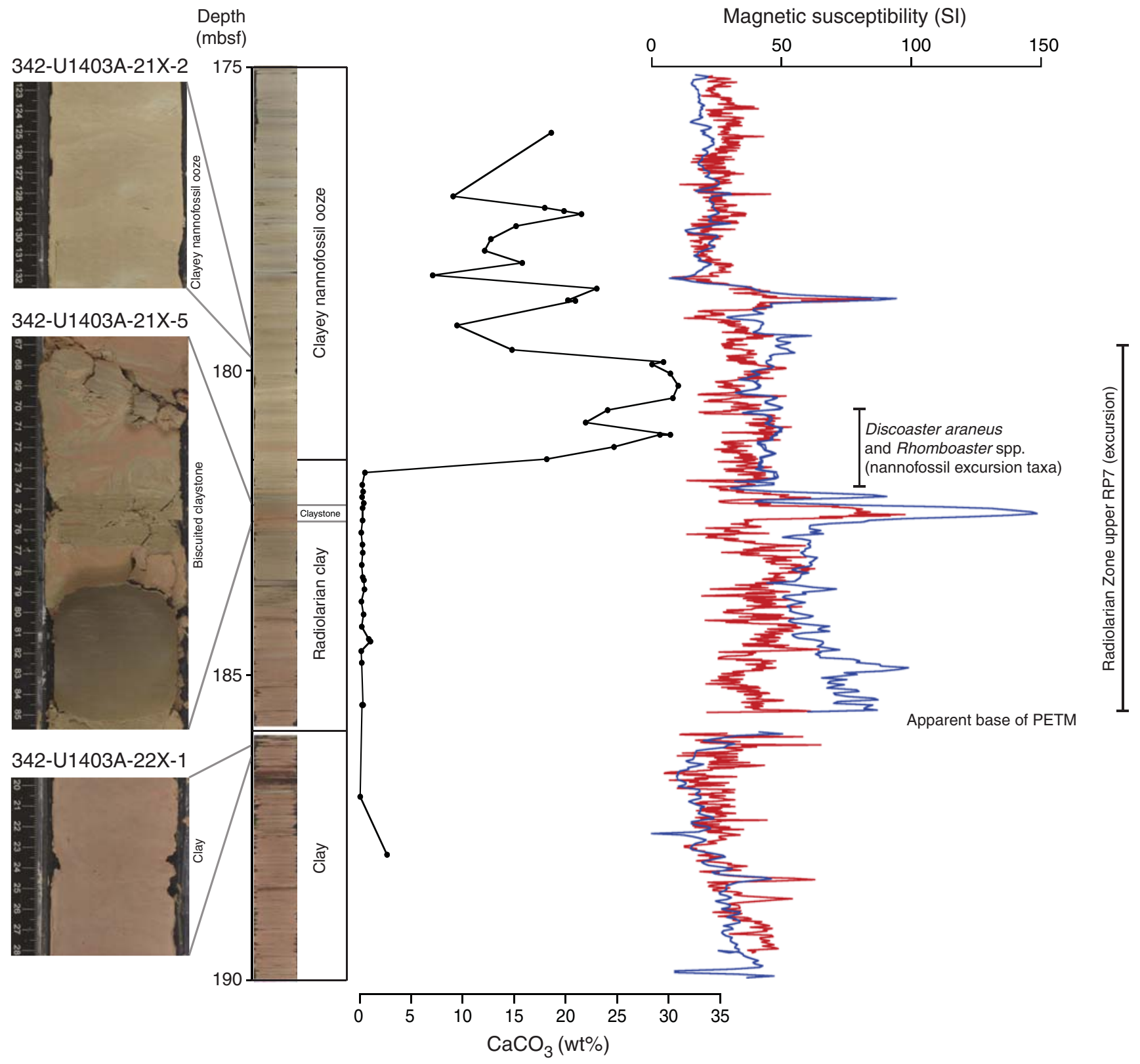


Figure F13. Plots of magnetic susceptibility and carbonate content variations in the interval spanning the Eocene Thermal Maximum 2 (ETM2) and Paleocene/Eocene Thermal Maximum (PETM) hyperthermal events, Site U1403. Magnetic susceptibility measurements were performed at high resolution $(1 \mathrm{~cm})$ on section halves using a Bartington MS2E probe (point measurements from the Section Half Multisensor Logger). A fifth-order polynomial fit is shown to indicate a parabolic trend bounding the two events.

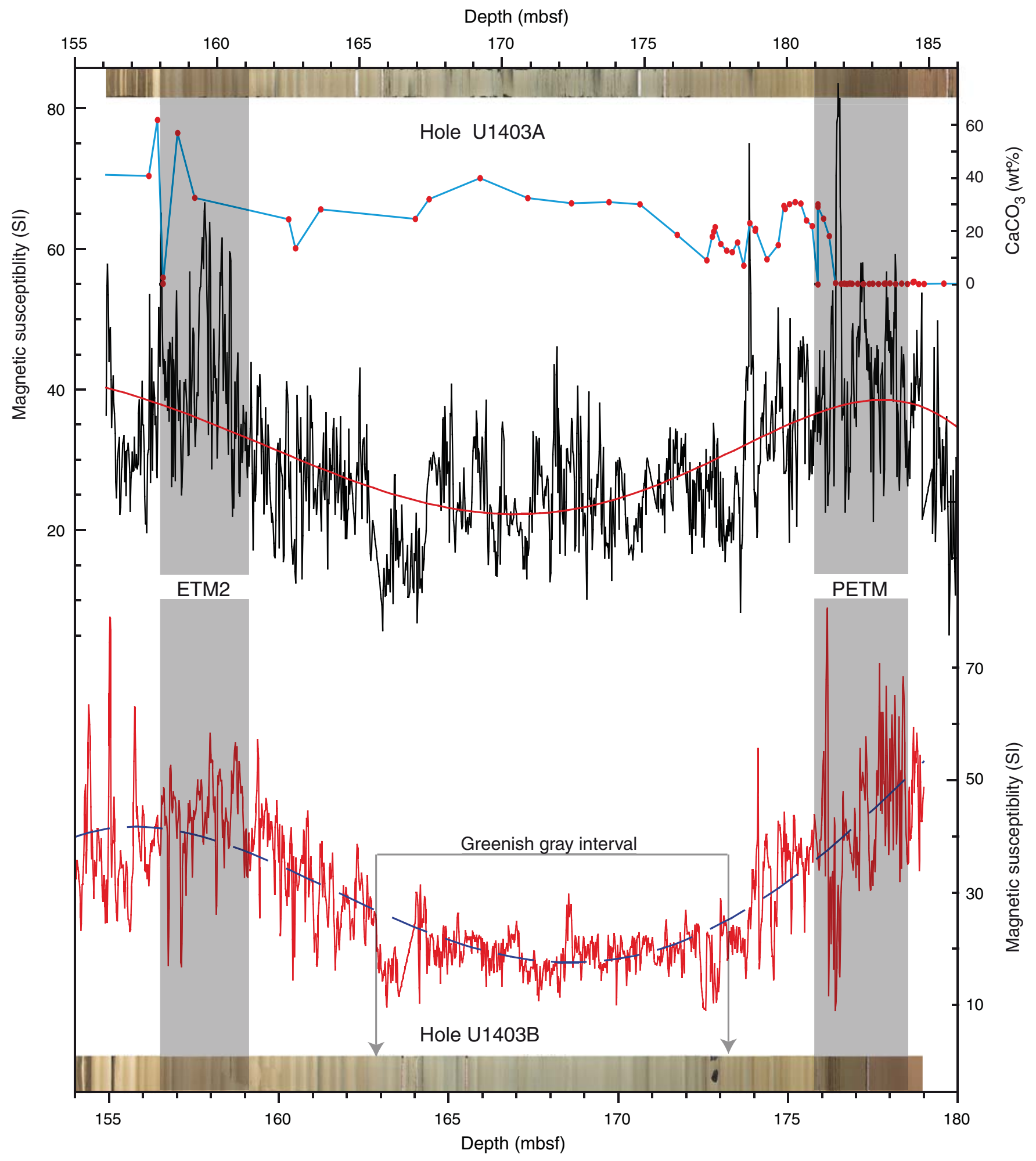


Figure F14. Line scan images and magnetic susceptibility, $b^{*}$, and natural gamma radiation (NGR) values of blue layer, Sections 342-U1403A-6H-2 and 342-U1403B-6H-5. Line in magnetic susceptibility plot is a sevenpoint running median to highlight trends (point measurements from Section Half Multisensor Logger [SHMSL]). Reflectance values of $b^{*}$ were measured with shipboard spectrophotometry on the SHMSL. NGR was measured with the Whole Round Multisensor Logger. Inset is an example of a probable feldspar crystal from the smear slide at $73 \mathrm{~cm}$ in Section 342-U1403B-6H-5.

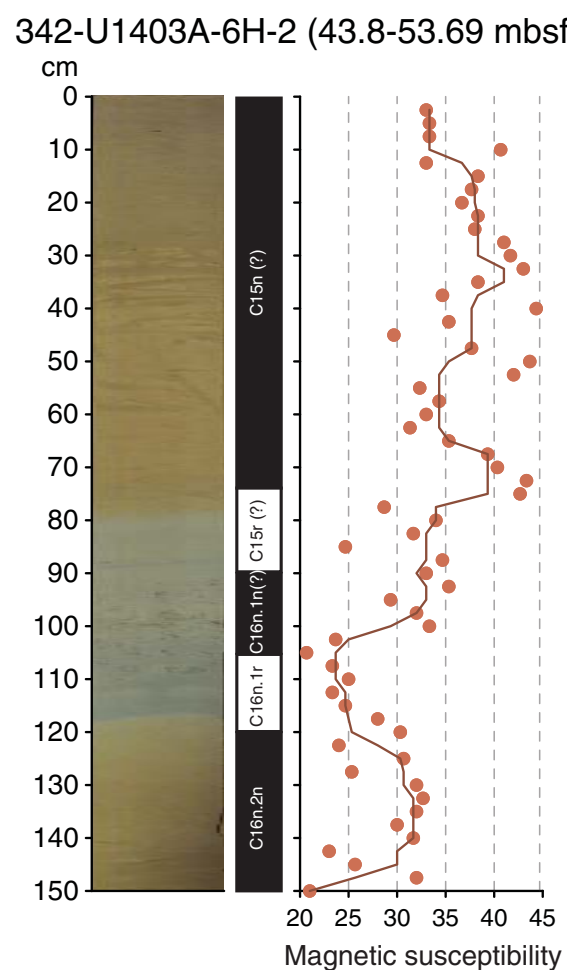

(SI)

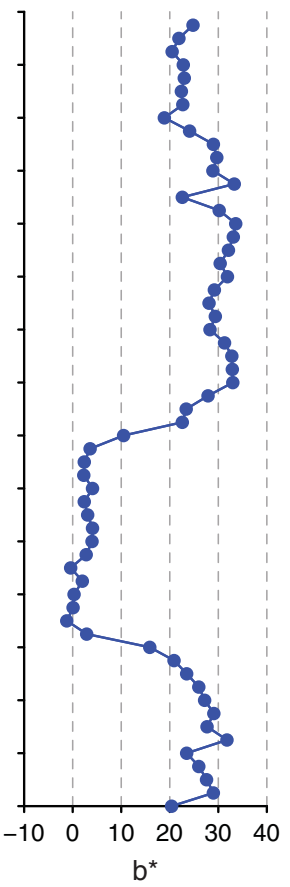

342-U1403B-6H-5 (34.9-45.04 mbsf)

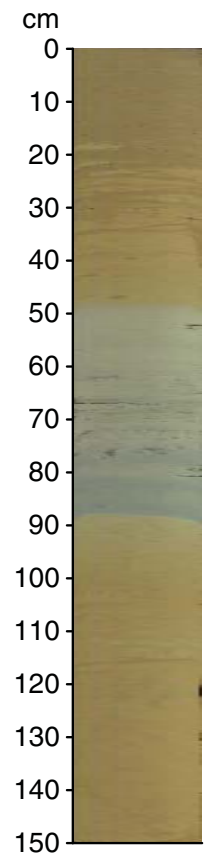

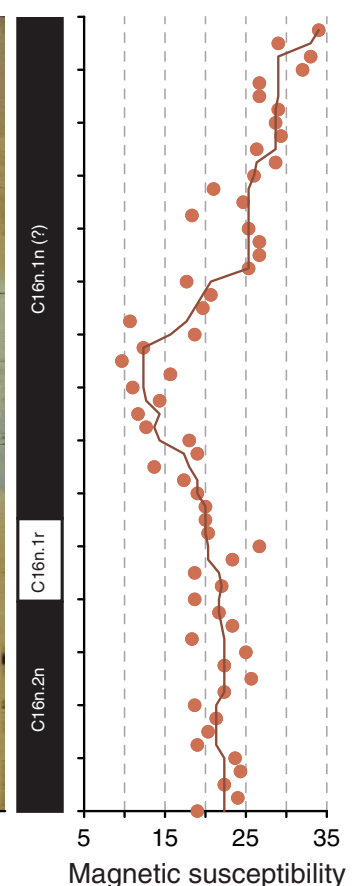

(SI)

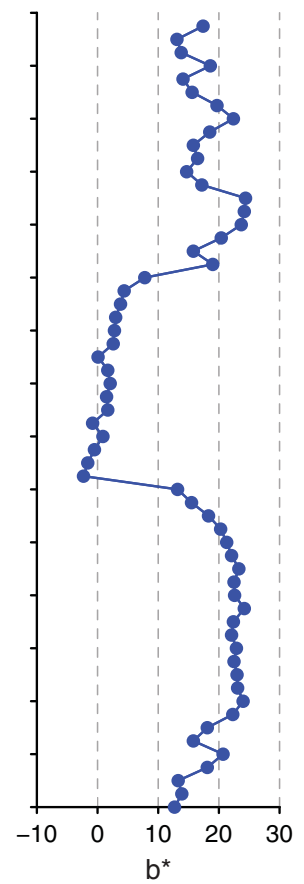

$b^{*}$

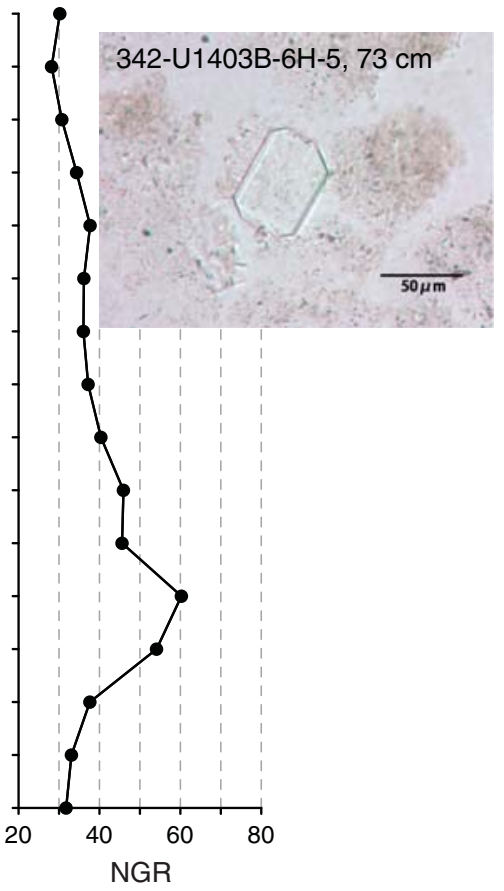

(cps)

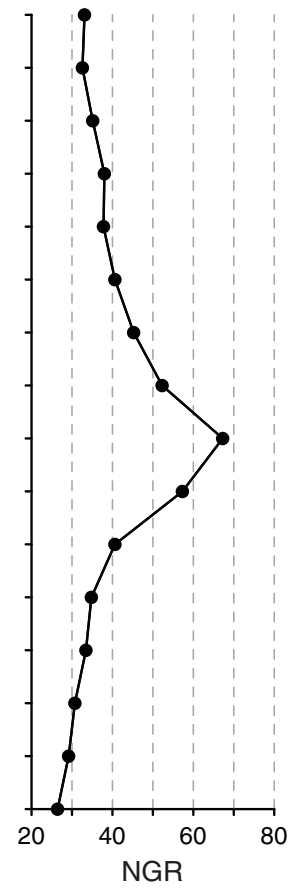

(cps) 
Figure F15. Integrated calcareous and siliceous microfossil biozonation, Site U1403.

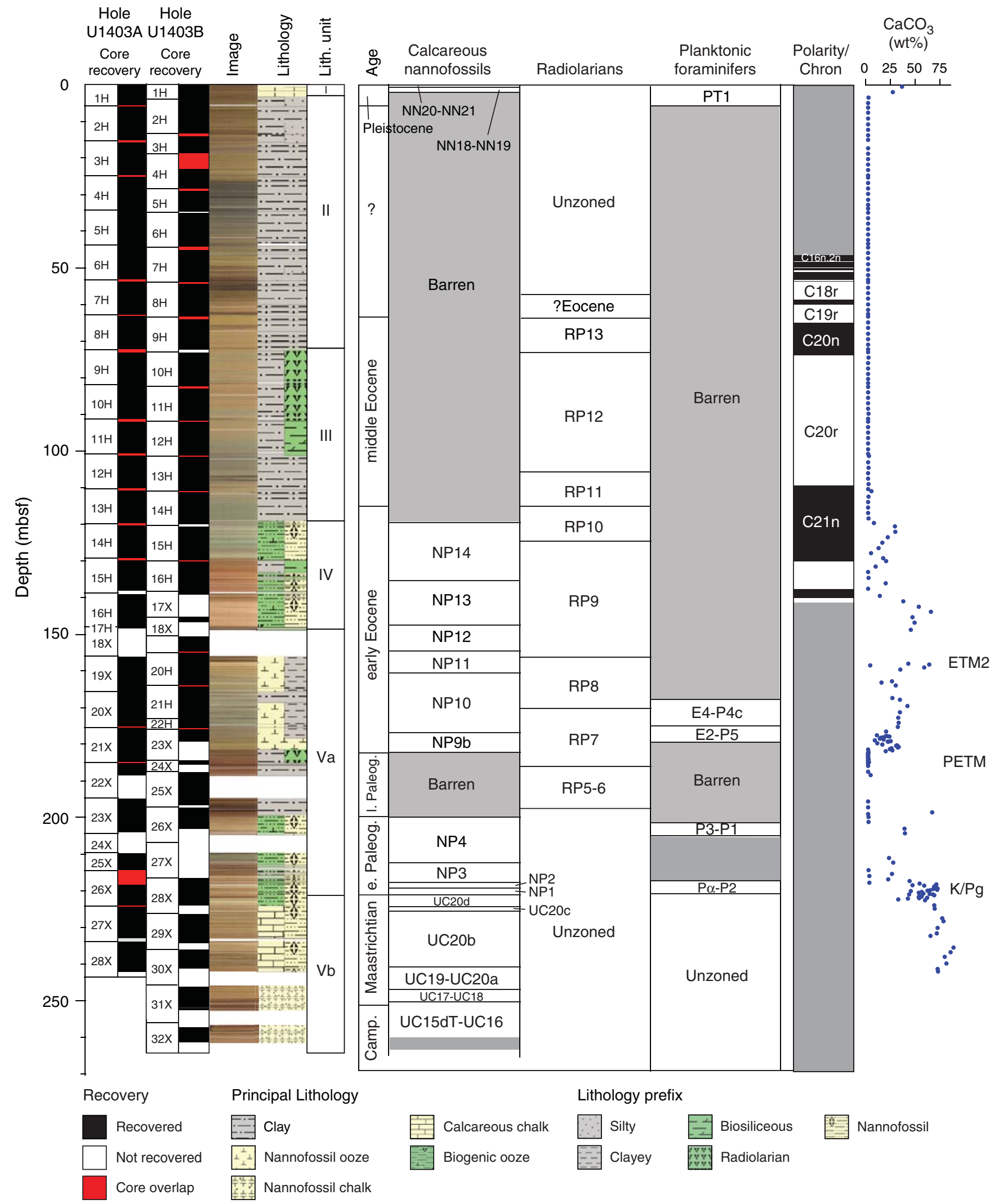


Figure F16. Plot of age-depth model for Hole U1403A showing biostratigraphic and magnetostratigraphic datums. Also shown are estimated linear sedimentation rates for line segments tied to the key datums listed in Table T18. Note that the lowermost datum is transferred from Hole U1403B.

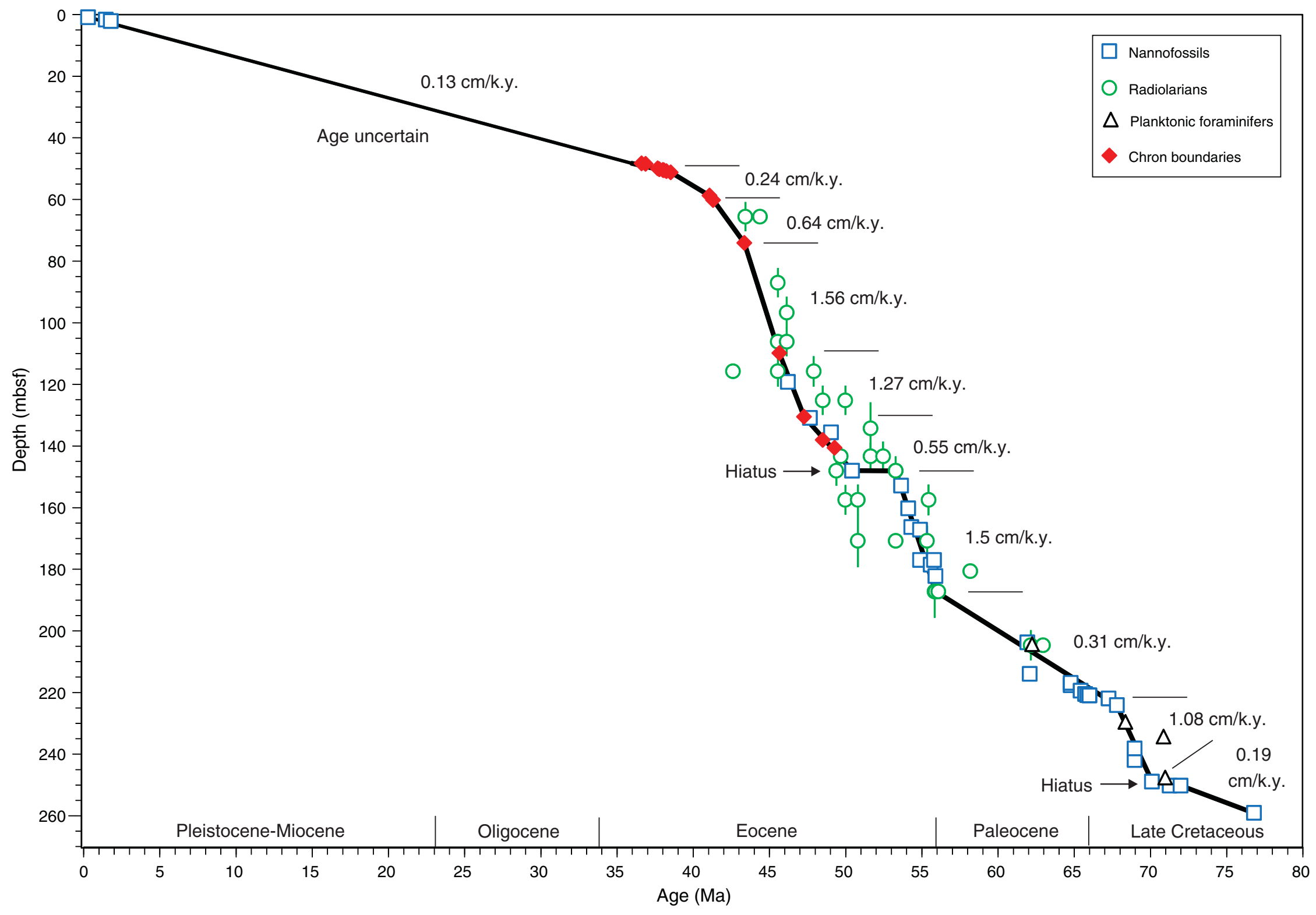


Figure F17. Plots of group abundance and preservation of calcareous and siliceous microfossils, Site U1403. Open and solid symbols represent Holes U1403A and U1403B, respectively. Abundance: $\mathrm{B}=$ barren, $\mathrm{P}=$ present, $\mathrm{R}=$ rare, $\mathrm{F}=$ few, $\mathrm{C}=$ common, $\mathrm{A}=$ abundant, $\mathrm{D}=$ dominant. Preservation: $\mathrm{P}$ = poor, $\mathrm{M}=$ moderate, $\mathrm{G}=$ good, $\mathrm{VG}=$ very good. ETM2 = Eocene Thermal Maximum 2, PETM = Paleocene/Eocene Thermal Maximum, $\mathrm{K} / \mathrm{Pg}=$ Cretaceous/Paleogene boundary.

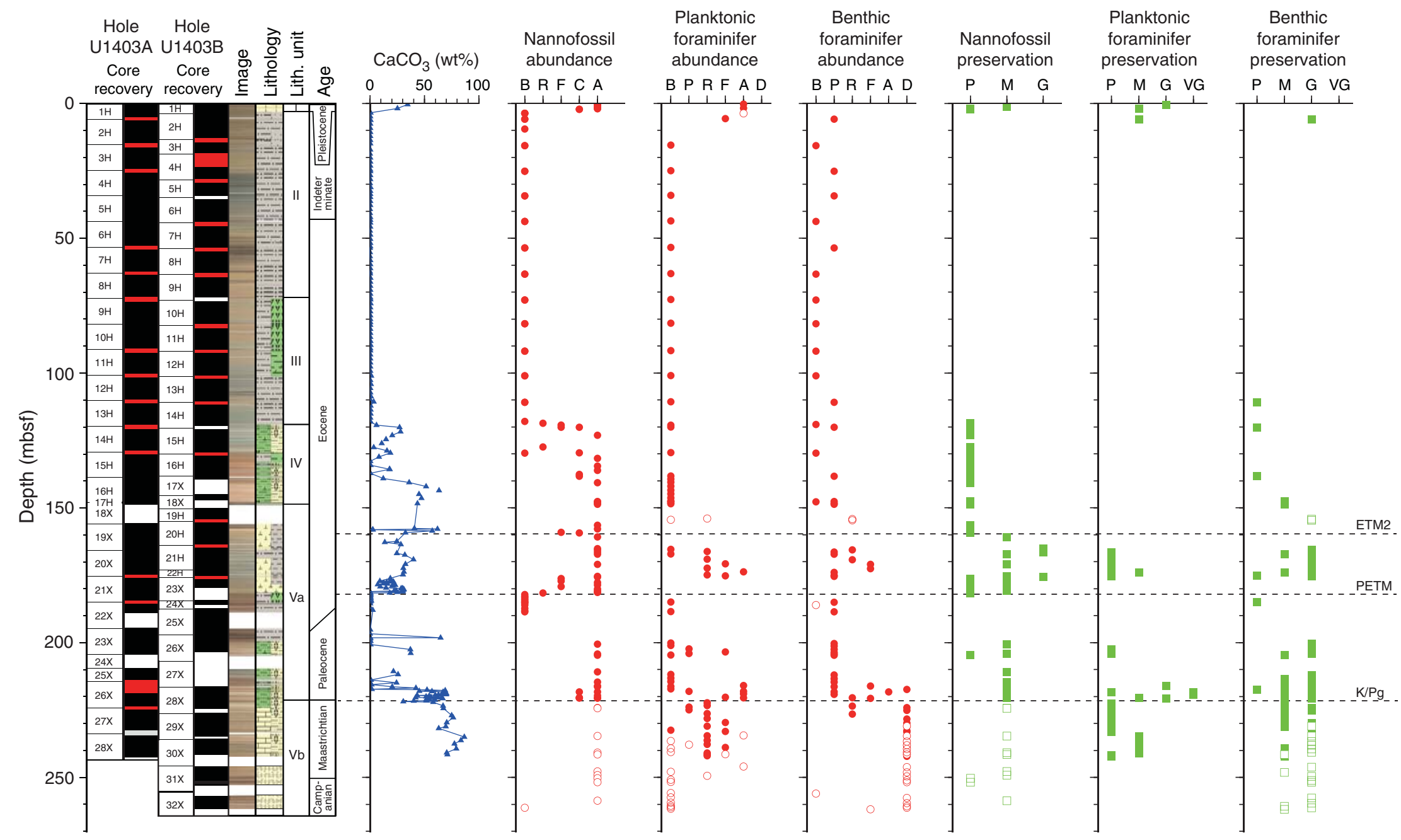


Figure F18. Plots of downhole variation of magnetic susceptibility and paleomagnetism data, Hole U1403A. Magnetization intensity, inclination, and declination are after $20 \mathrm{mT}$ demagnetization and shown in geographic (sample) coordinates for the oriented advanced piston corer (APC) and extended core barrel (XCB) intervals. For discrete sample data, if the samples were analyzed by principal component analysis (PCA; Kirschvink, 1980), then directions are shown according to PCA declination and inclination. Otherwise, directions following $20 \mathrm{mT}$ demagnetization are shown. Polarity: black = normal chron, white = reversed chron, gray $=$ unidentified interval.

Hole U1403A

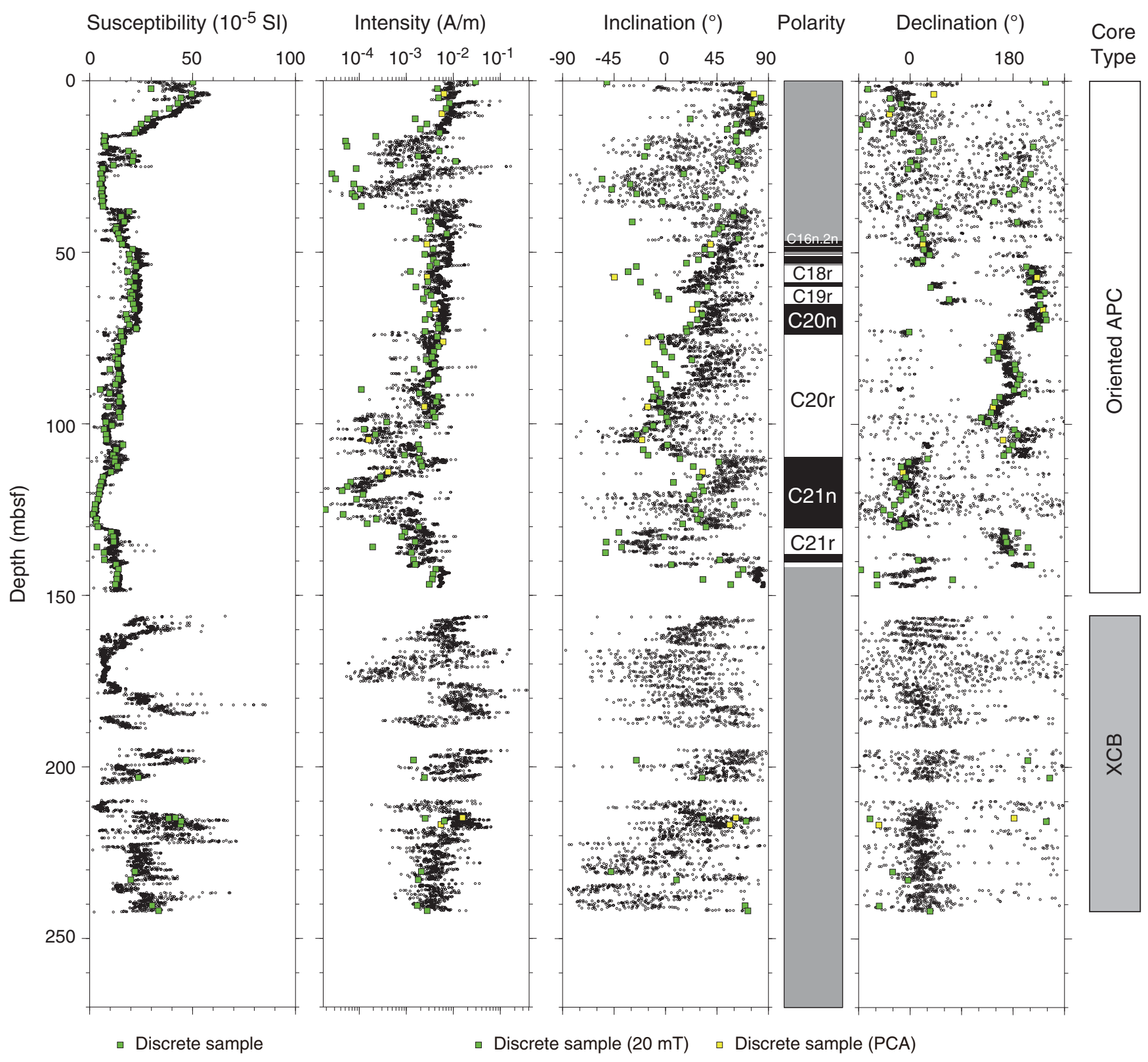


Figure F19. Plots of downhole variation of magnetic susceptibility and paleomagnetism data, Hole U1403B. Magnetization intensity, inclination, and declination are after $20 \mathrm{mT}$ demagnetization. Only oriented advanced piston corer (APC) intervals show directions in geographic coordinates. Directions from all other intervals are shown in sample coordinates. For discrete sample data, if the samples were analyzed by principal component analysis (PCA; Kirschvink, 1980), then directions are shown according to PCA declination and inclination. Otherwise, directions following $20 \mathrm{mT}$ demagnetization are shown. $\mathrm{XCB}=$ extended core barrel. Polarity: black $=$ normal chron, white $=$ reversed chron, gray $=$ unidentified interval .

Hole U1403B

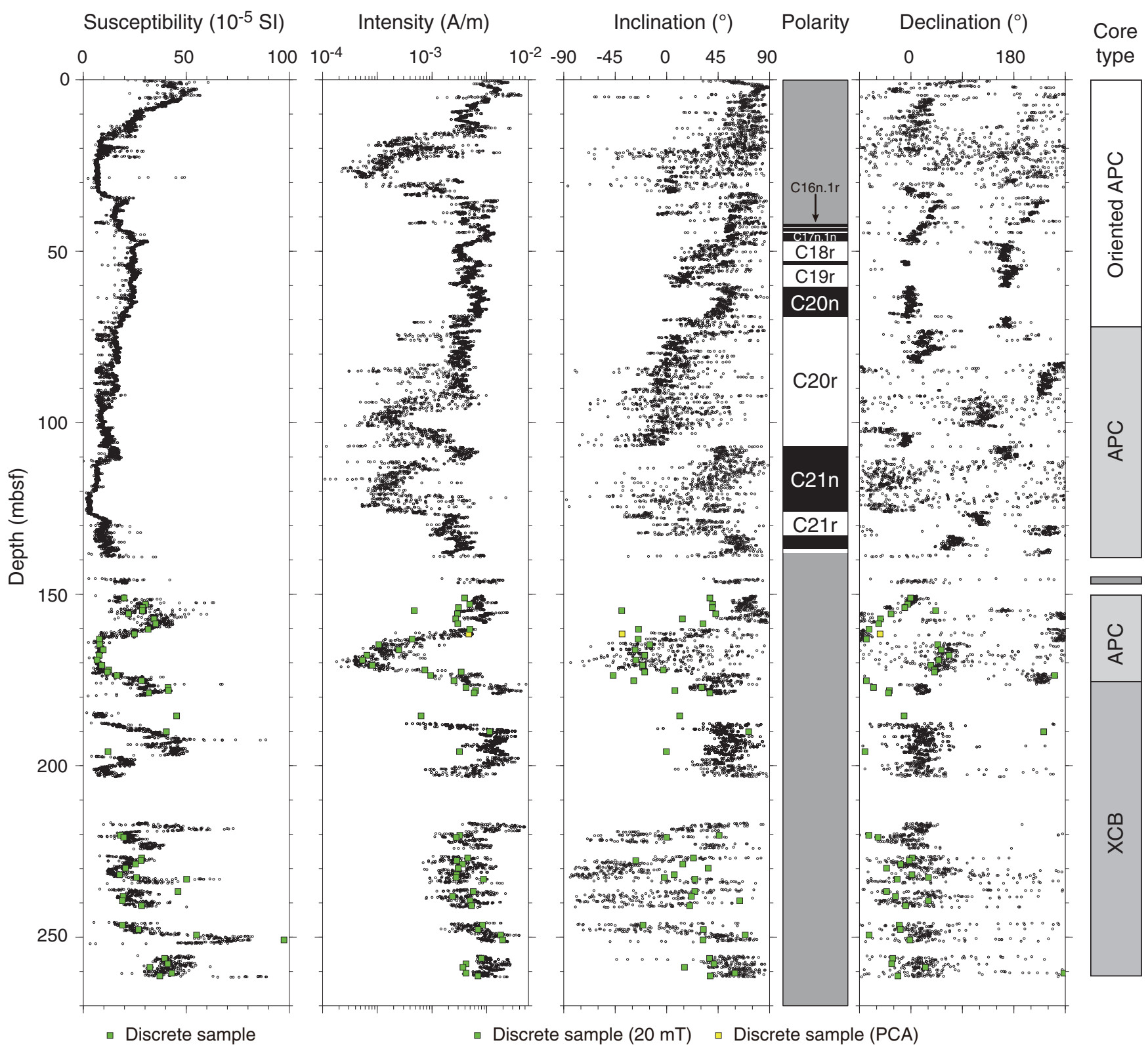


Figure F20. Plots of representative alternating field (AF) demagnetization results for discrete paleomagnetism samples, Site U1403. Upper plots show intensity variation with progressive demagnetization, and lower plots show vector endpoints of paleomagnetism directions on orthogonal vector diagrams (i.e., Zijderveld plots). Vector diagrams indicate that samples in $\mathbf{A}$ and $\mathbf{B}$ record well-resolved characteristic remanent magnetization $(\mathrm{ChRM})$ directions, whereas the sample in $\mathbf{C}$ does not. Solid circles $=$ horizontal projections, open circles $=$ vertical projections, gray circles $=$ data not used to calculate ChRM direction, black dashed line $=$ ChRM direction. Inc $=$ inclination, $\mathrm{Dec}=$ declination, $\mathrm{MAD}=$ maximum angle of deviation .
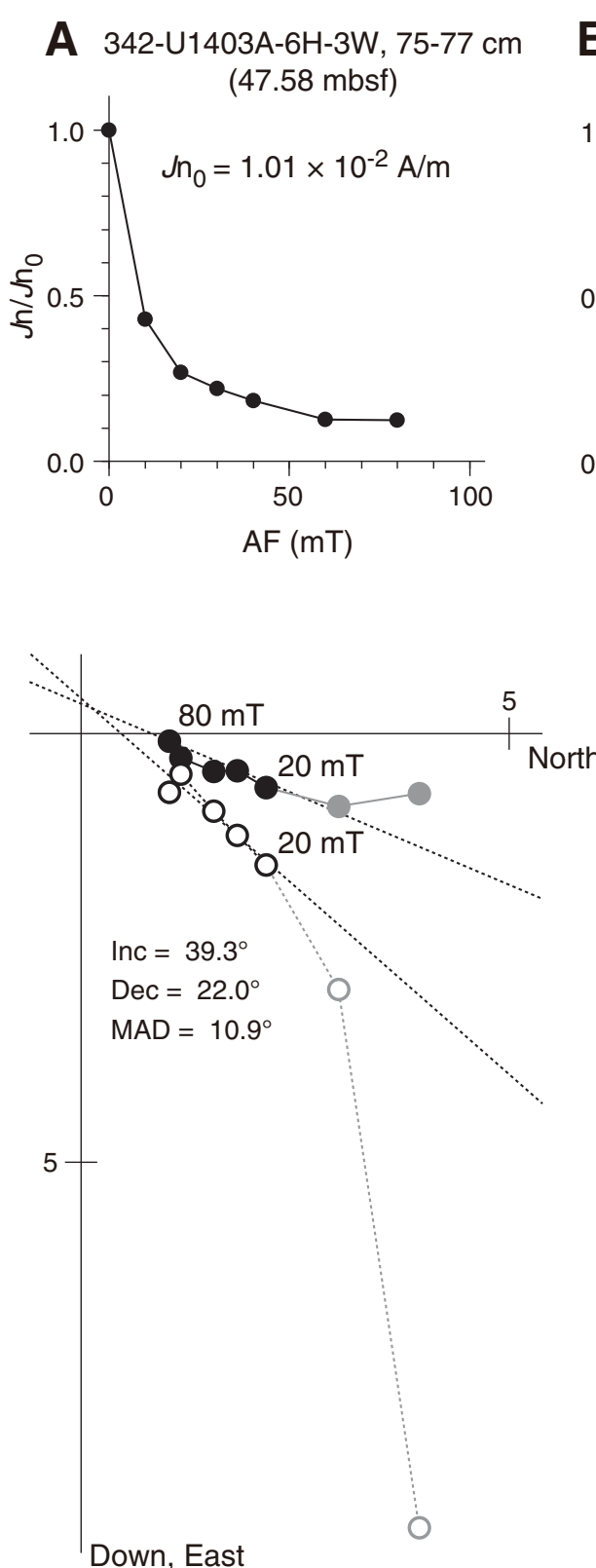
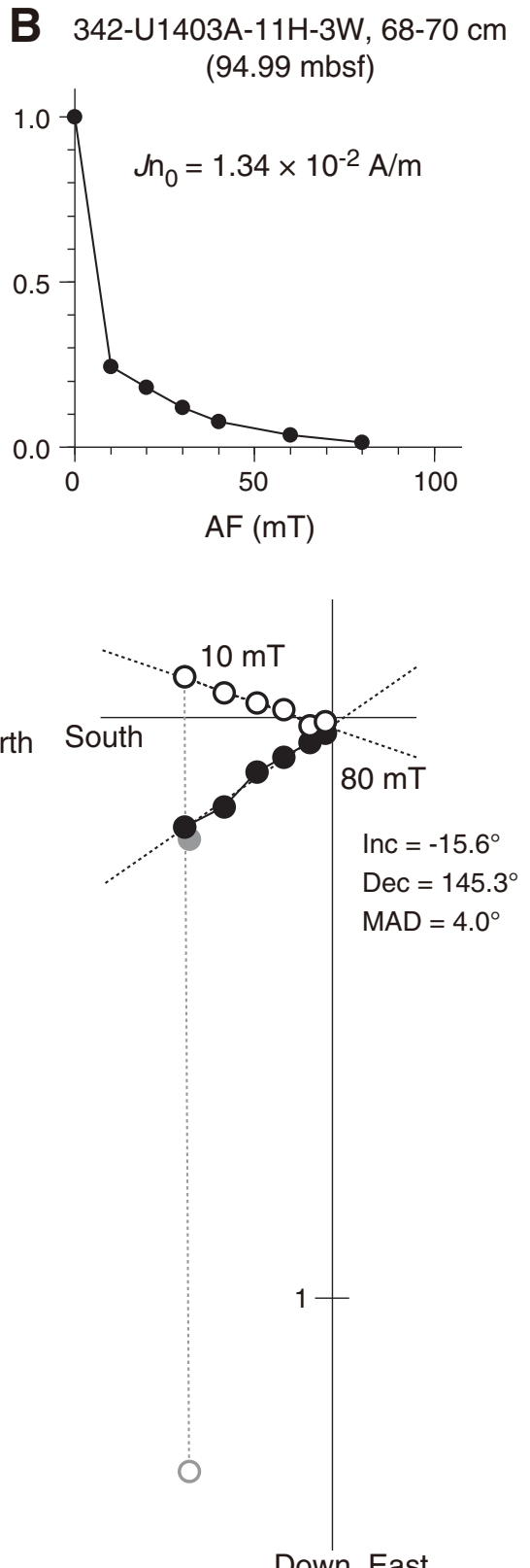
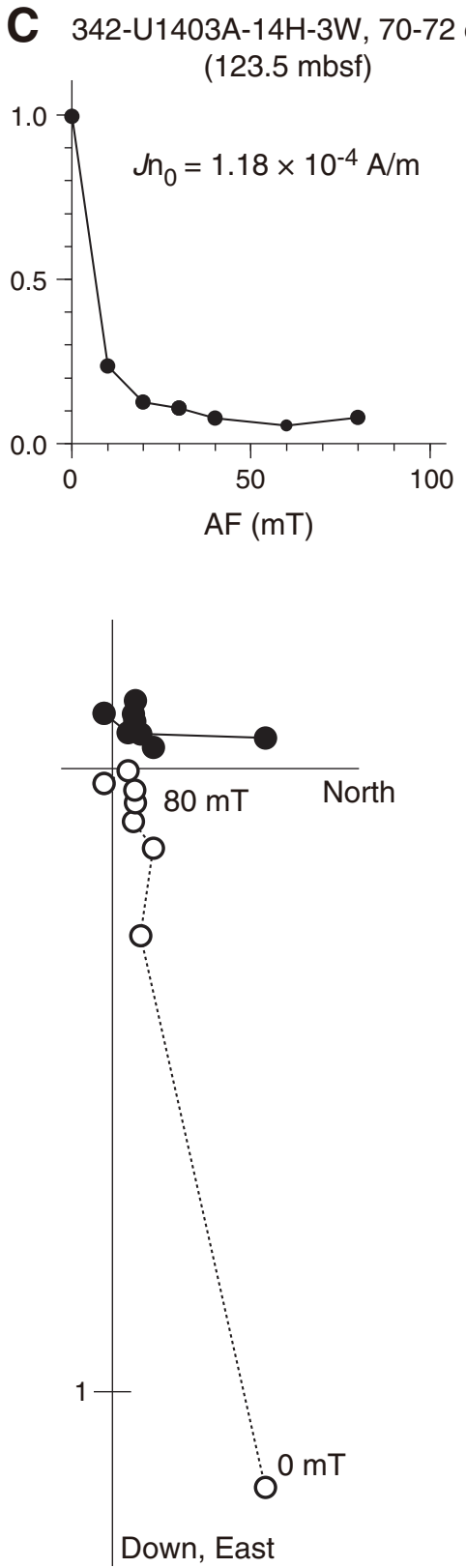
Figure F21. Illustration of magnetostratigraphy, Site U1403. Core recovery: black $=$ recovered core, red $=$ core overlap.

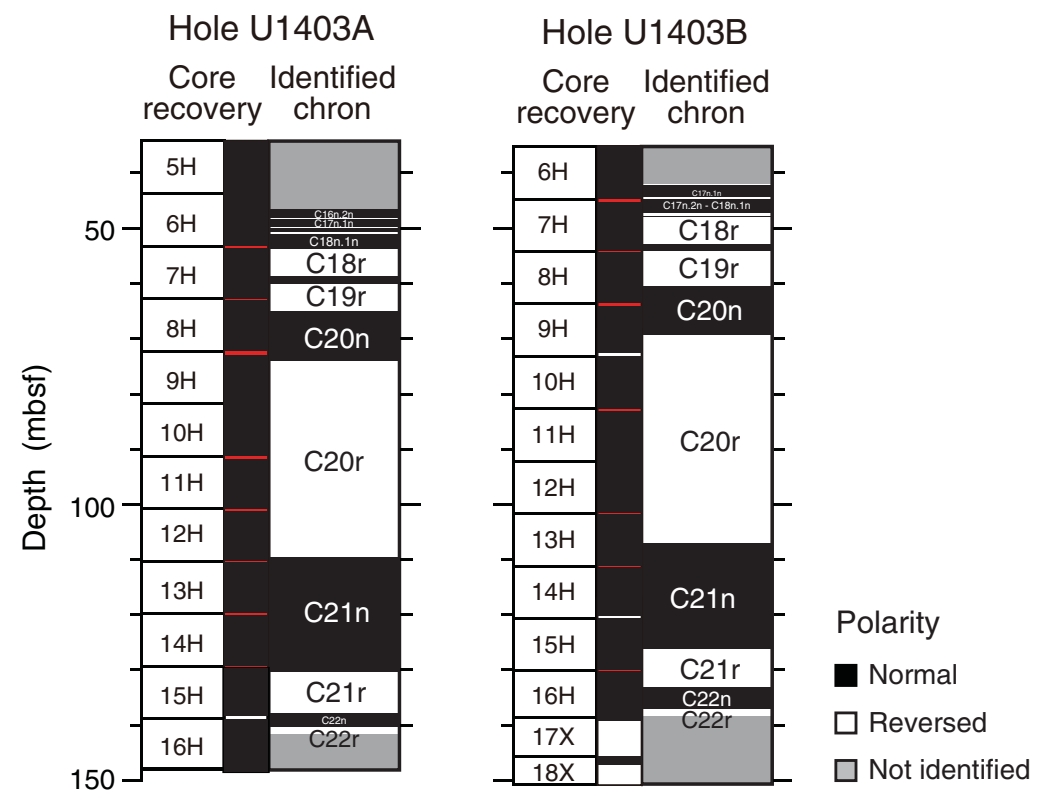


Figure F22. Plots of anisotropy of magnetic susceptibility, bulk density, and porosity vs. depth, Hole U1403A. Separation of eigenvalues is related to the shape and degree of magnetic fabric (see "Paleomagnetism" in the "Methods" chapter [Norris et al., 2014b]). For example, if $\tau_{1}$ and $\tau_{2}$ are close or indistinguishable but distinct from $\tau_{3}$, then the bulk fabric is oblate. Bulk density and porosity are described in "Physical properties" and lithostratigraphic units in "Lithostratigraphy." Eigenvalues: $\tau_{1}=$ maximum, $\tau_{2}=$ intermediate, $\tau_{3}=$ minimum. $V_{3}=$ minimum eigenvector, $P=$ degree of anisotropy $\left(\tau_{1} / \tau_{3}\right)$. APC $=$ advanced piston corer, $\mathrm{XCB}=$ extended core barrel.

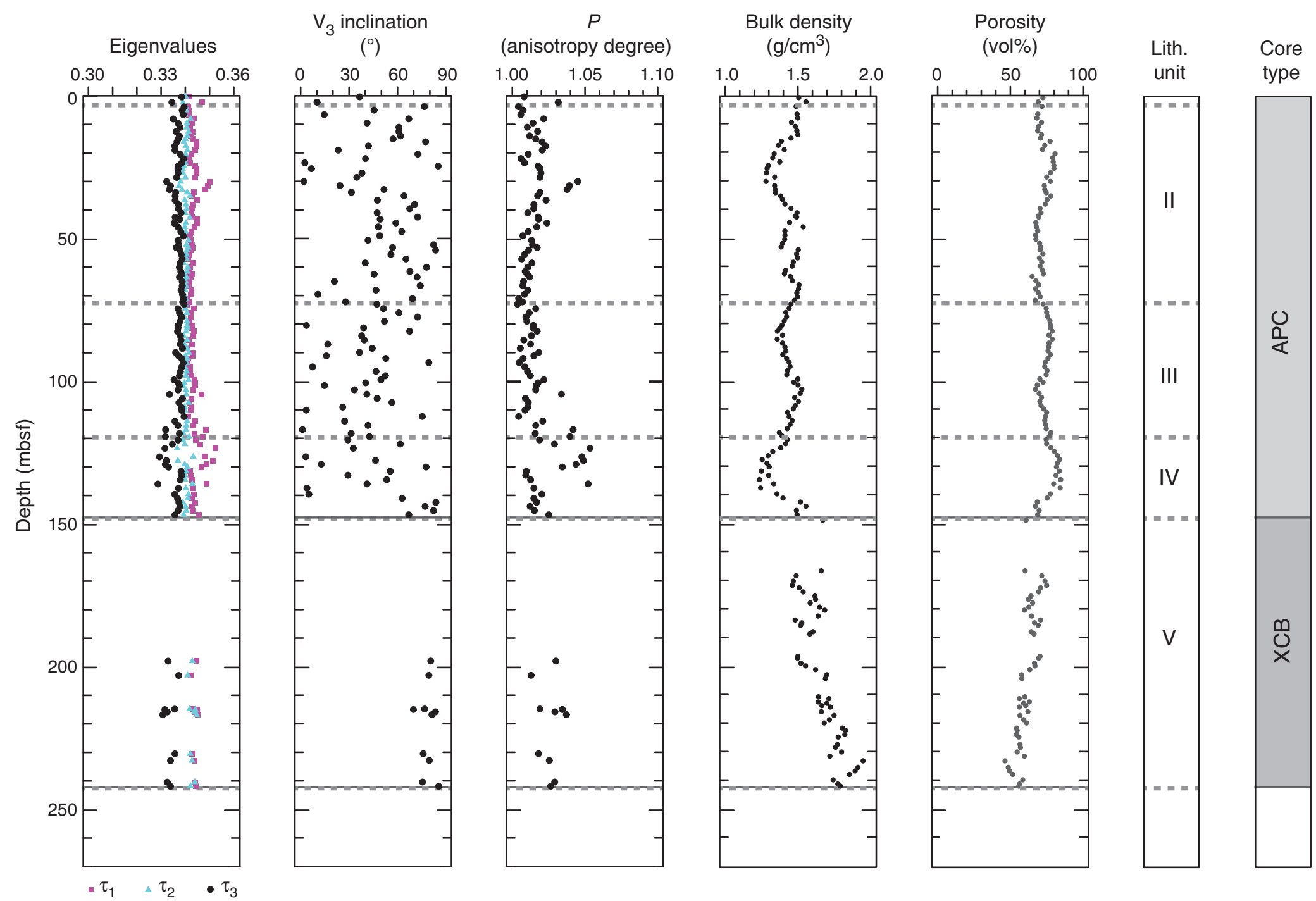


Figure F23. Plots of anisotropy of magnetic susceptibility vs. depth, Hole U1403B. Separation of eigenvalues is related to the shape and degree of magnetic fabric (see "Paleomagnetism" in the "Methods" chapter [Norris et al., 2014b]). For example, if $\tau_{1}$ and $\tau_{2}$ are close or indistinguishable but distinct from $\tau_{3}$, then the bulk fabric is oblate. Bulk density and porosity are described in "Physical properties" and lithostratigraphic units in "Lithostratigraphy." Eigenvalues: $\tau_{1}=$ maximum, $\tau_{2}=$ intermediate, $\tau_{3}=$ minimum. $\mathrm{V}_{3}=$ minimum eigenvector, $P=$ degree of anisotropy $\left(\tau_{1} / \tau_{3}\right)$. APC = advanced piston corer, $\mathrm{XCB}=$ extended core barrel.

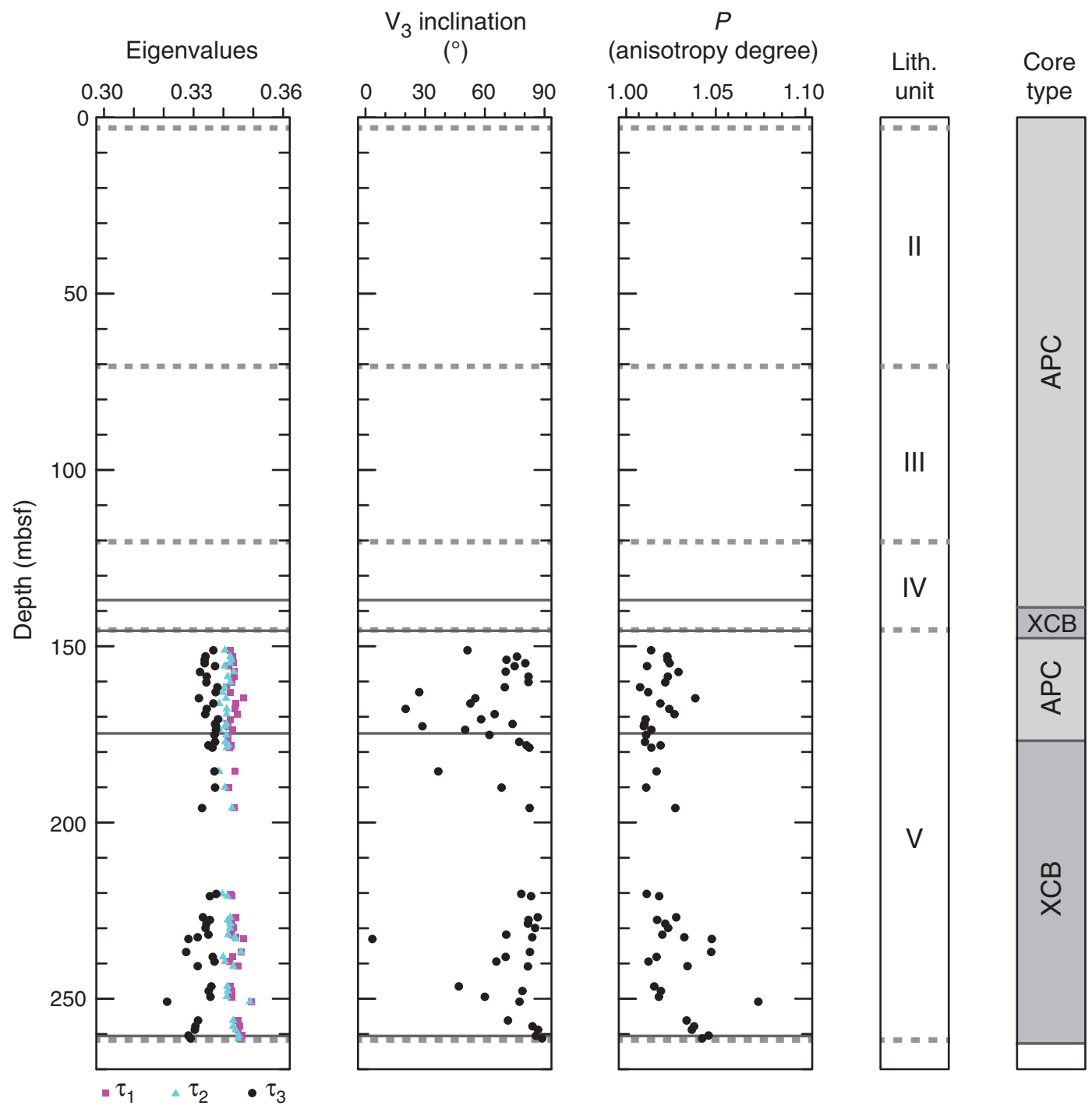


Figure F24. Plots of linear sedimentation rate (LSR), dry bulk density (DBD), carbonate content, and mass accumulation rate (MAR) at 200 k.y. time steps, Hole U1403A. Solid black diamonds show the inflection points in estimated LSR, DBD, and carbonate content. Geologic ages are shown on the GTS2012 timescale (Gradstein et al., 2012). $\mathrm{CAR}=$ carbonate mass accumulation rate, $\mathrm{nCAR}=$ noncarbonate mass accumulation rate.
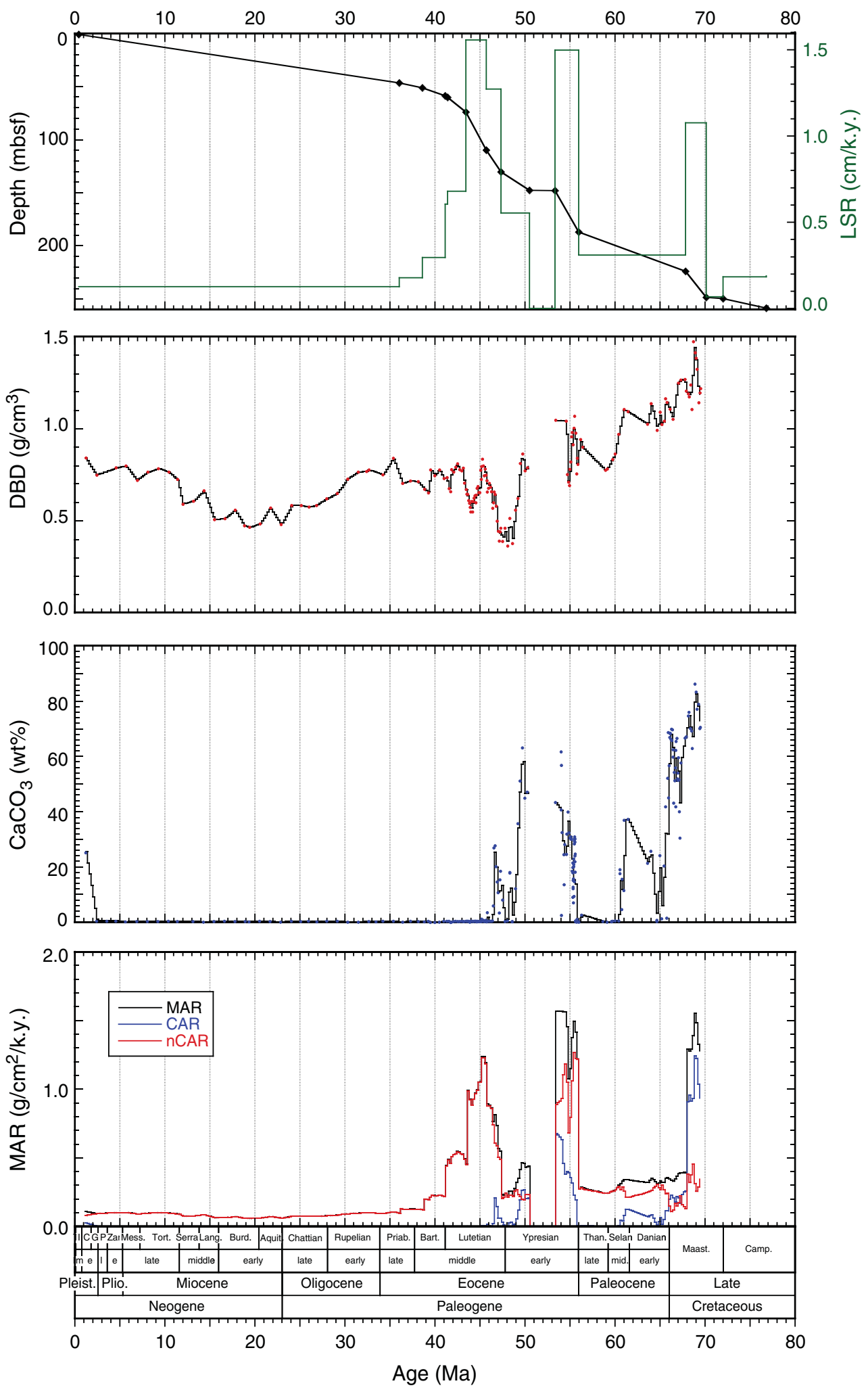
Figure F25. Plots of interstitial water constituent concentrations, Hole U1403A. IC = ion chromatography.

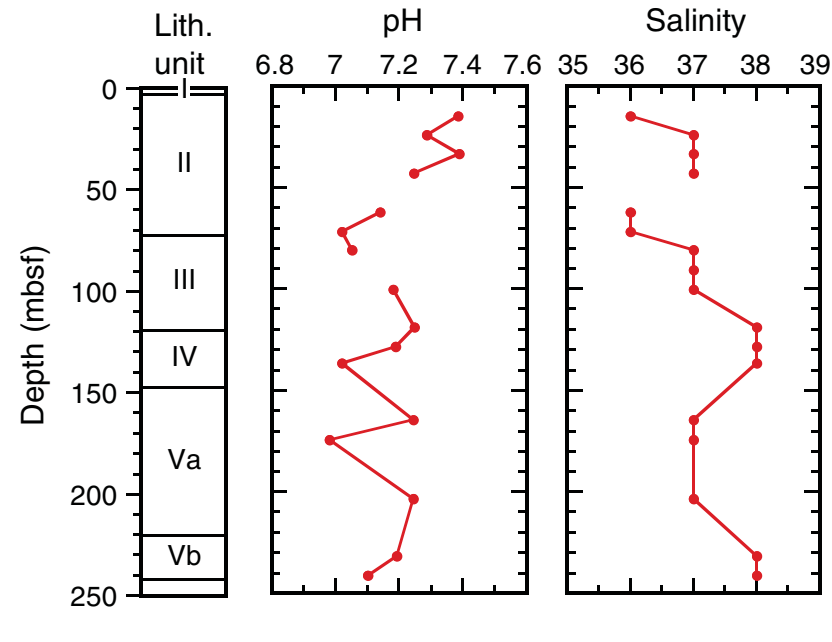

Salinity

Chloride (mM)

Sodium (mM)
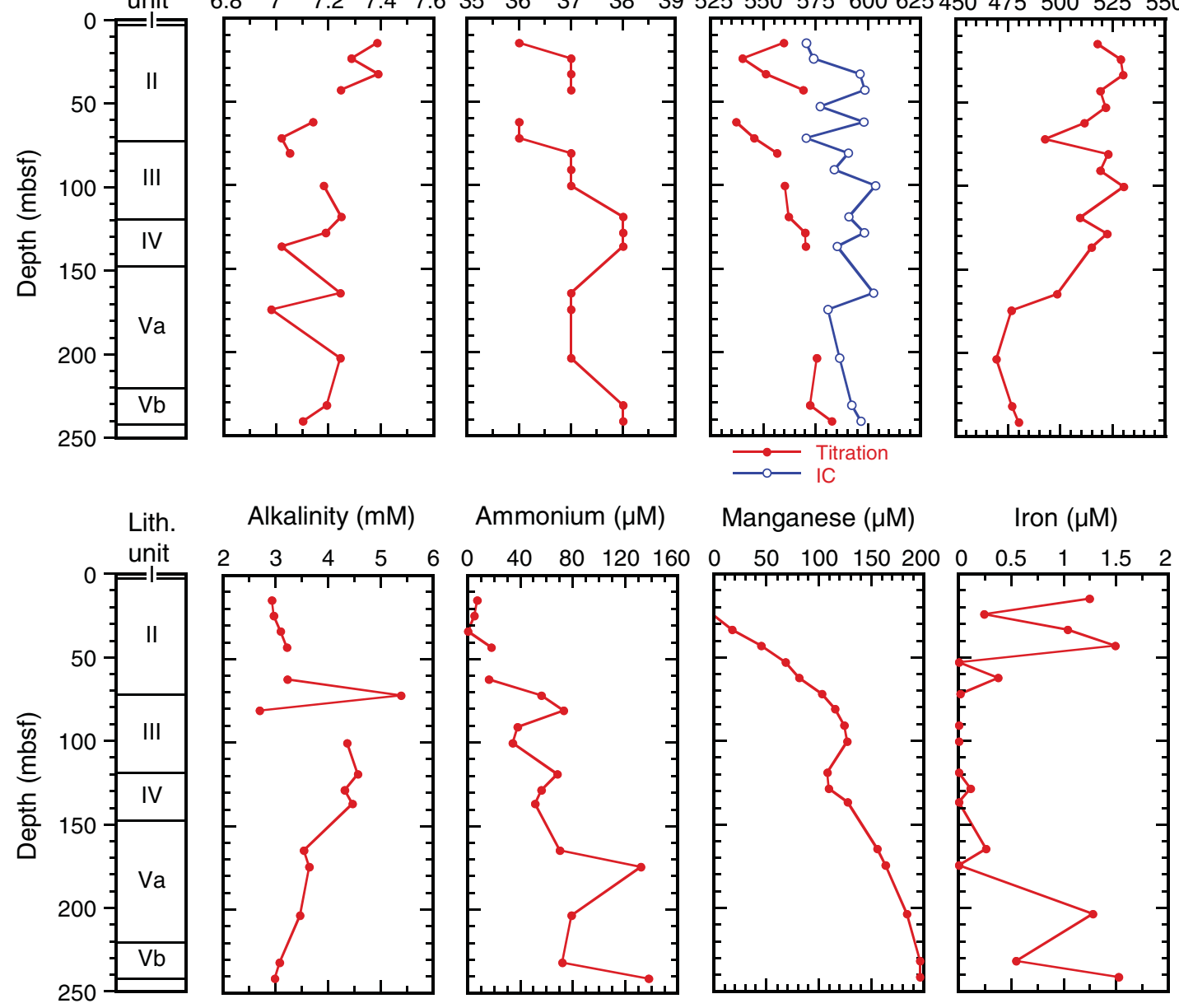

Ammonium $(\mu \mathrm{M})$

Manganese $(\mu \mathrm{M})$

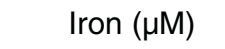

Sulfate (mM)
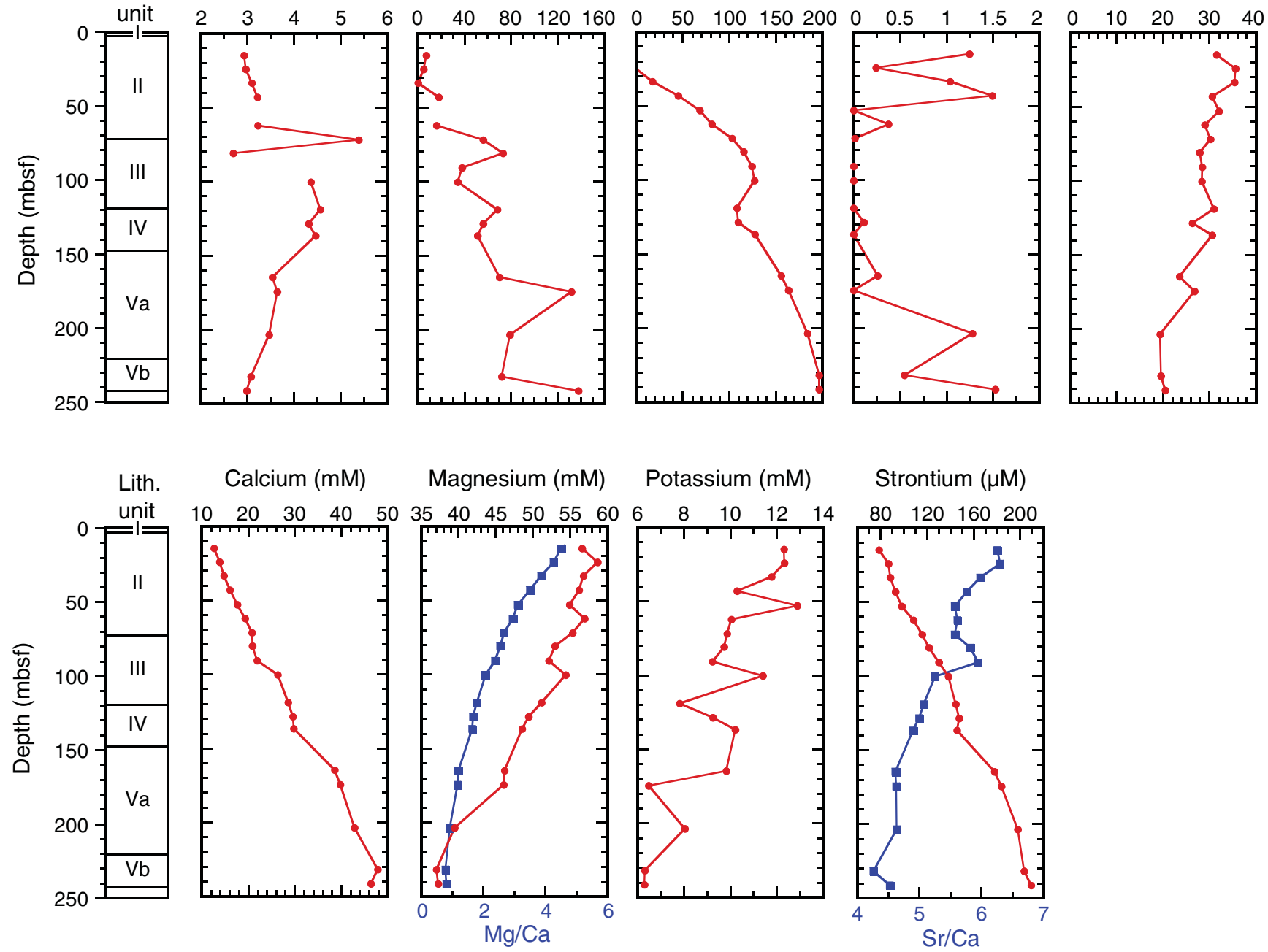
Figure F26. Plots of sedimentary carbonate contents, Hole U1403A. Core recovery: black $=$ recovered, gray $=$ not recovered, red $=$ overlap.

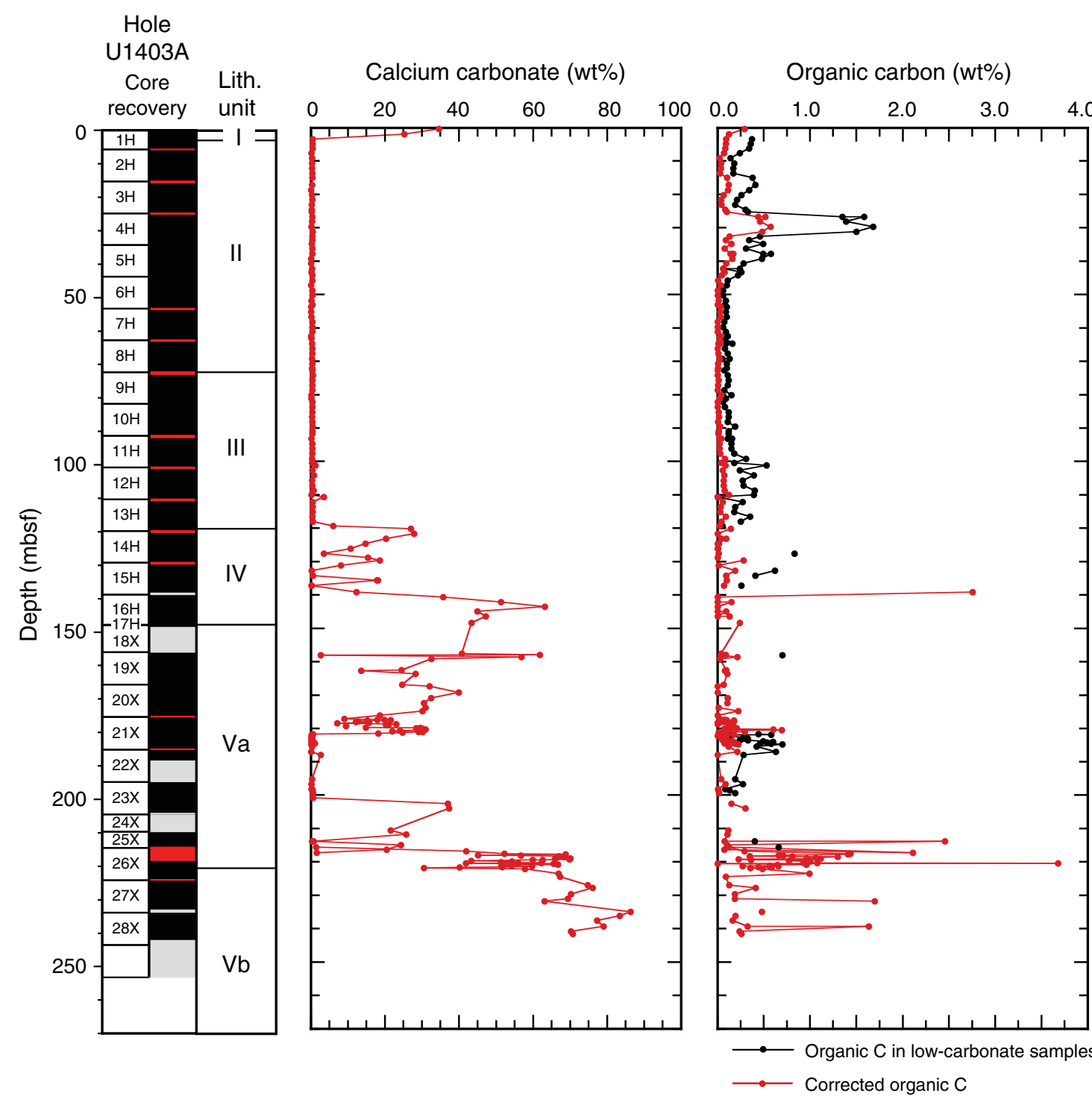

Total nitrogen (wt\%)

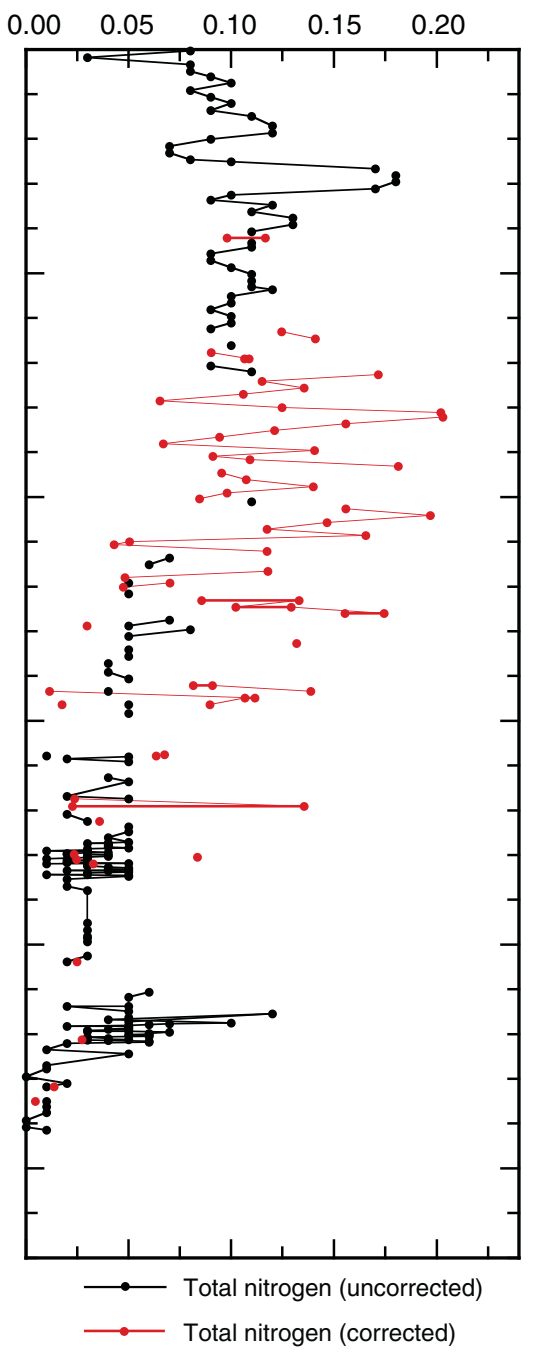


Figure F27. Plot of carbonate content in the interval corresponding to the Paleocene/Eocene Thermal Maximum, Core 342-U1403A-21X.

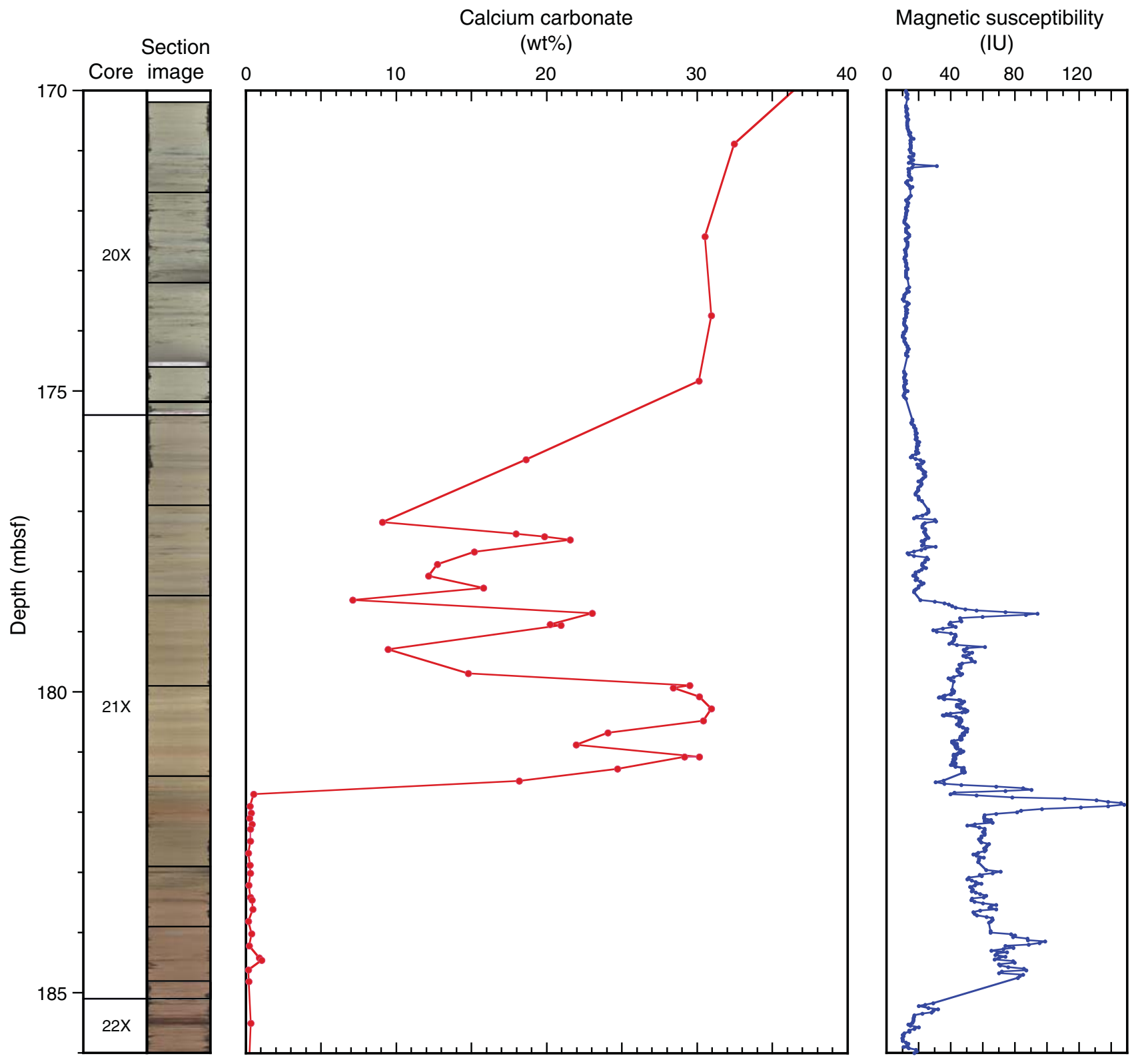


Figure F28. Plot of carbonate content and magnetic susceptibility in the interval corresponding to the Cretaceous/Paleogene boundary, Core 342-U1403A-26X.

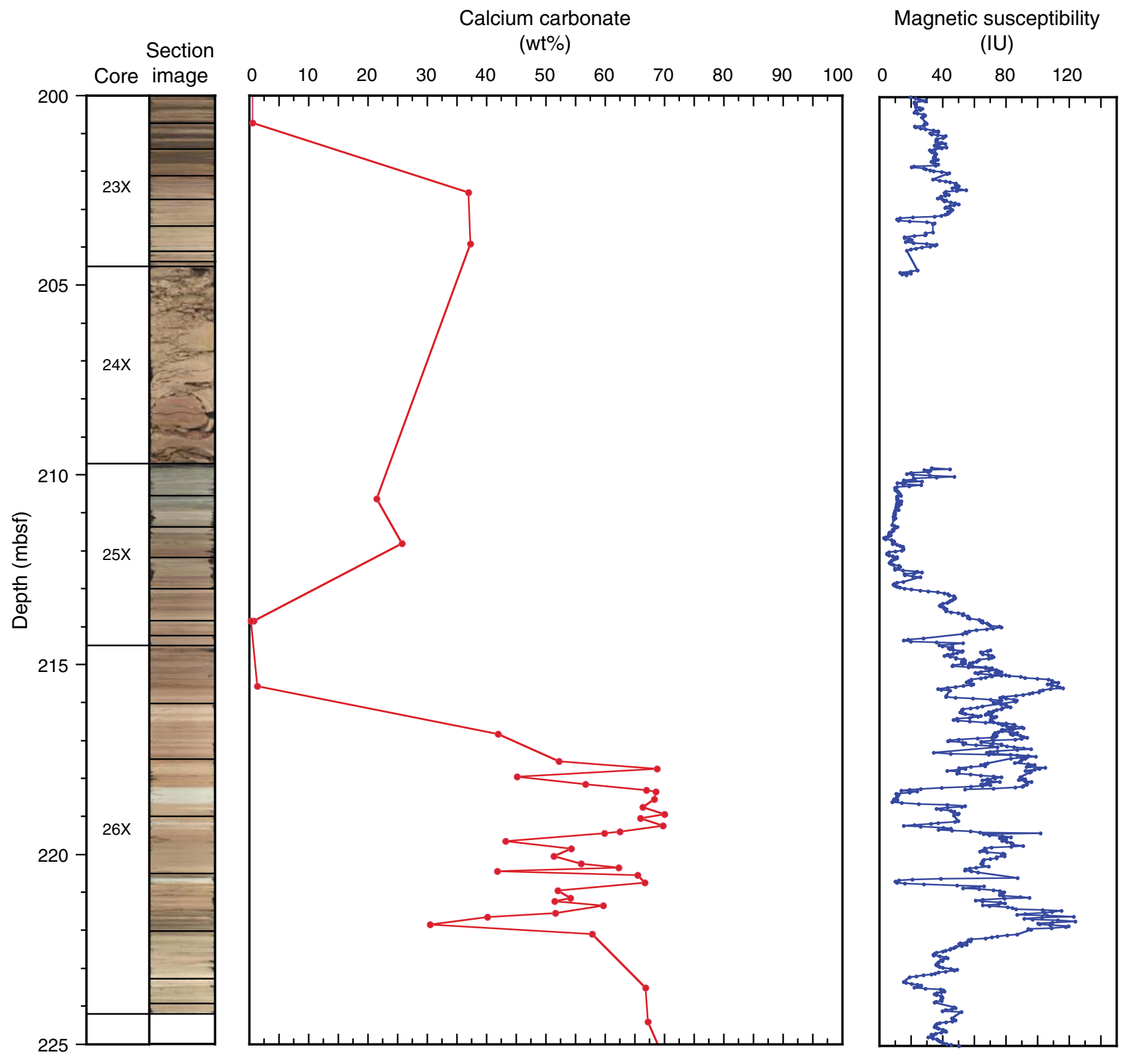


Figure F29. Plots of magnetic susceptibility (MS), bulk density (gray line = gamma ray attenuation density from Whole-Round Multisensor Logger, black circles = moisture and density analysis from discrete samples), porosity, water content, and grain density, Site U1403. Core recovery: black $=$ recovered, white $=$ not recovered, red = overlap. Horizontal gray lines indicate lithostratigraphic unit boundaries (see "Lithostratigraphy"). APC $=$ advanced piston corer, $\mathrm{XCB}=$ extended core barrel.
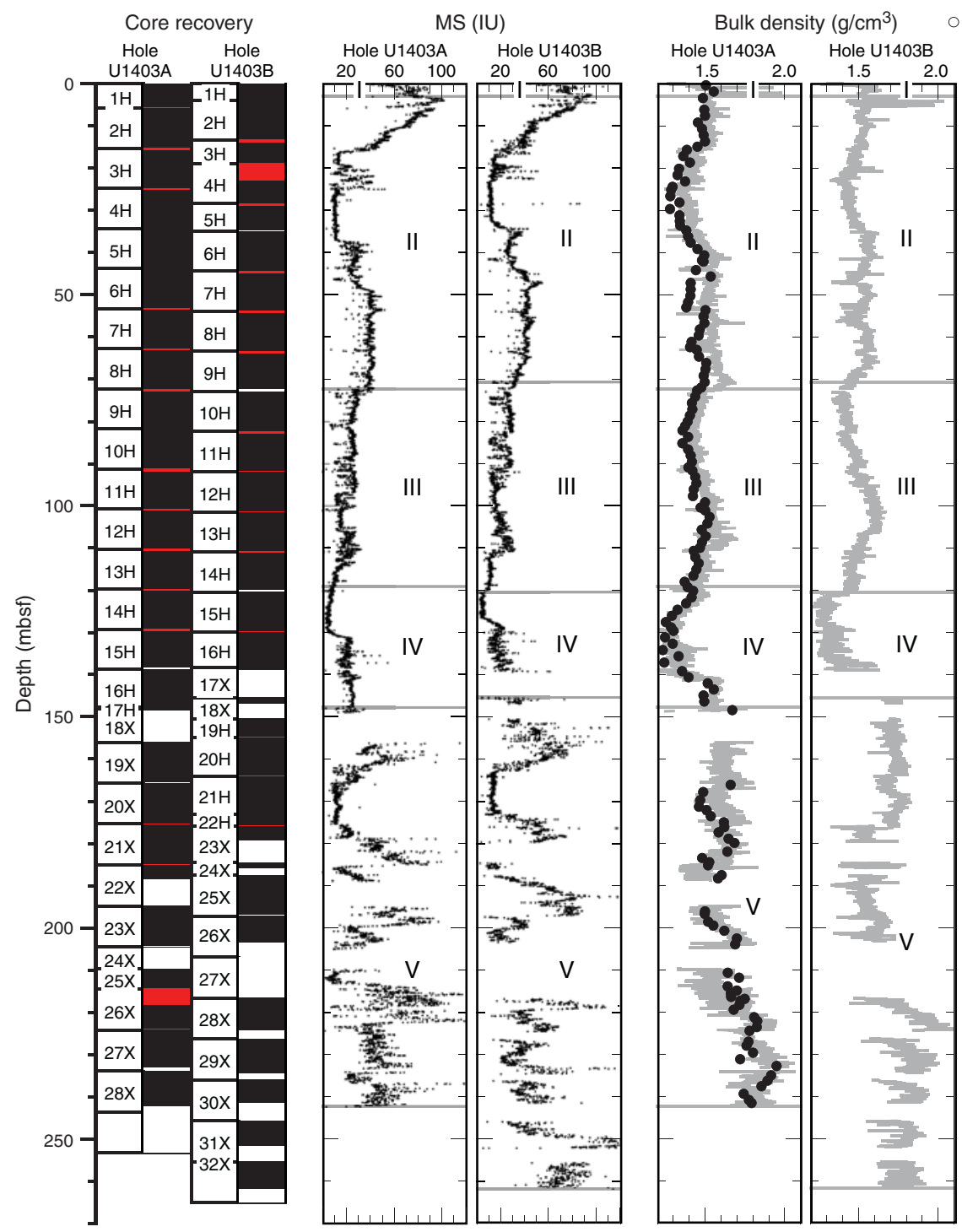

Water content (wt\%) Grain density $\left(\mathrm{g} / \mathrm{cm}^{3}\right)$ Coring system
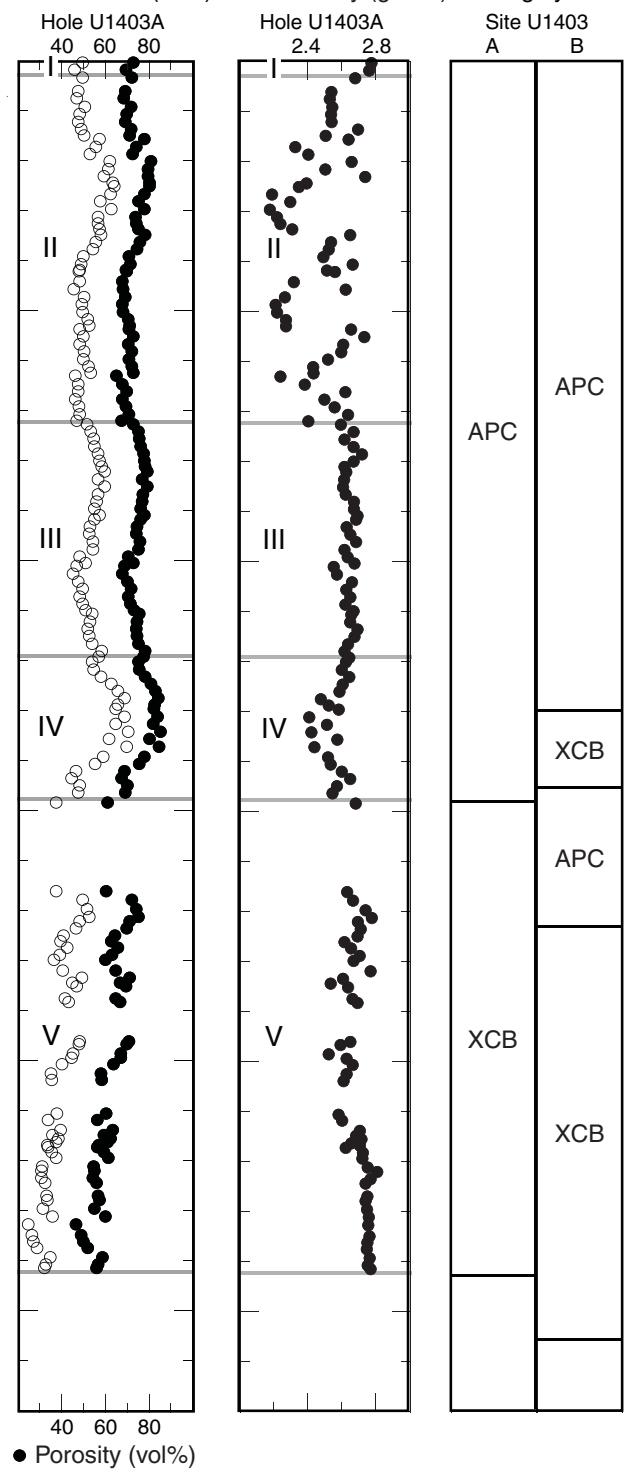

- Porosity (vol\%) 
Figure F30. Plots of magnetic susceptibility (MS), $P$-wave velocity (gray line $=P$-wave logger data, black circles $=$ caliper data), and natural gamma radiation (NGR), Site U1403. Core recovery: black = recovered, white $=$ not recovered, red $=$ overlap. Horizontal gray lines indicate lithostratigraphic unit boundaries (see "Lithostratigraphy"). APC = advanced piston corer, XCB = extended core barrel.
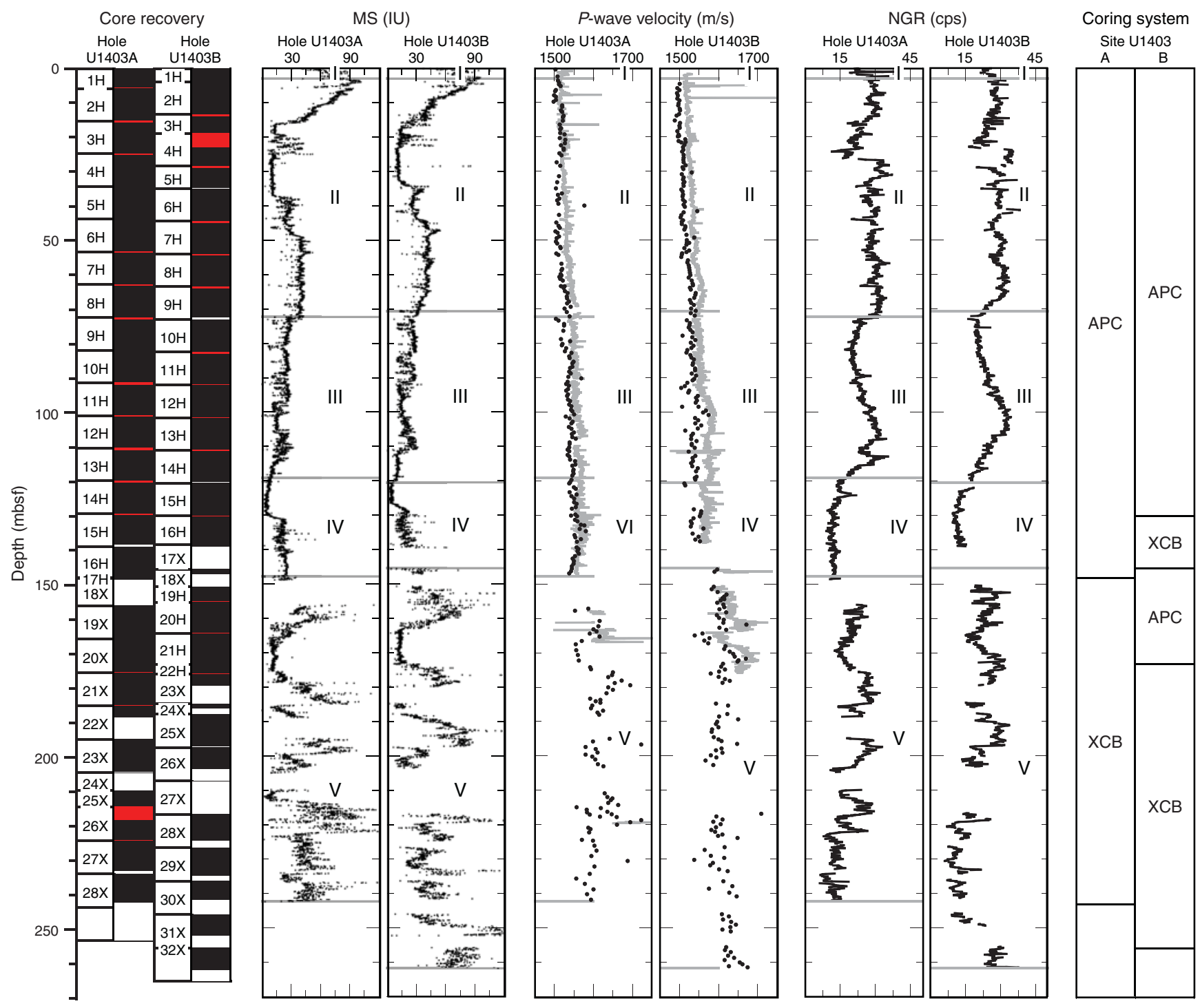
Figure F31. Plots of magnetic susceptibility (MS) and color reflectance parameters $\left(a^{*}, b^{*}\right.$, and $\left.L^{*}\right)$, Site U1403. Core recovery: black $=$ recovered, white $=$ not recovered, red $=$ overlap. Horizontal gray lines indicate lithostratigraphic unit boundaries (see "Lithostratigraphy"). APC = advanced piston corer, XCB = extended core barrel.
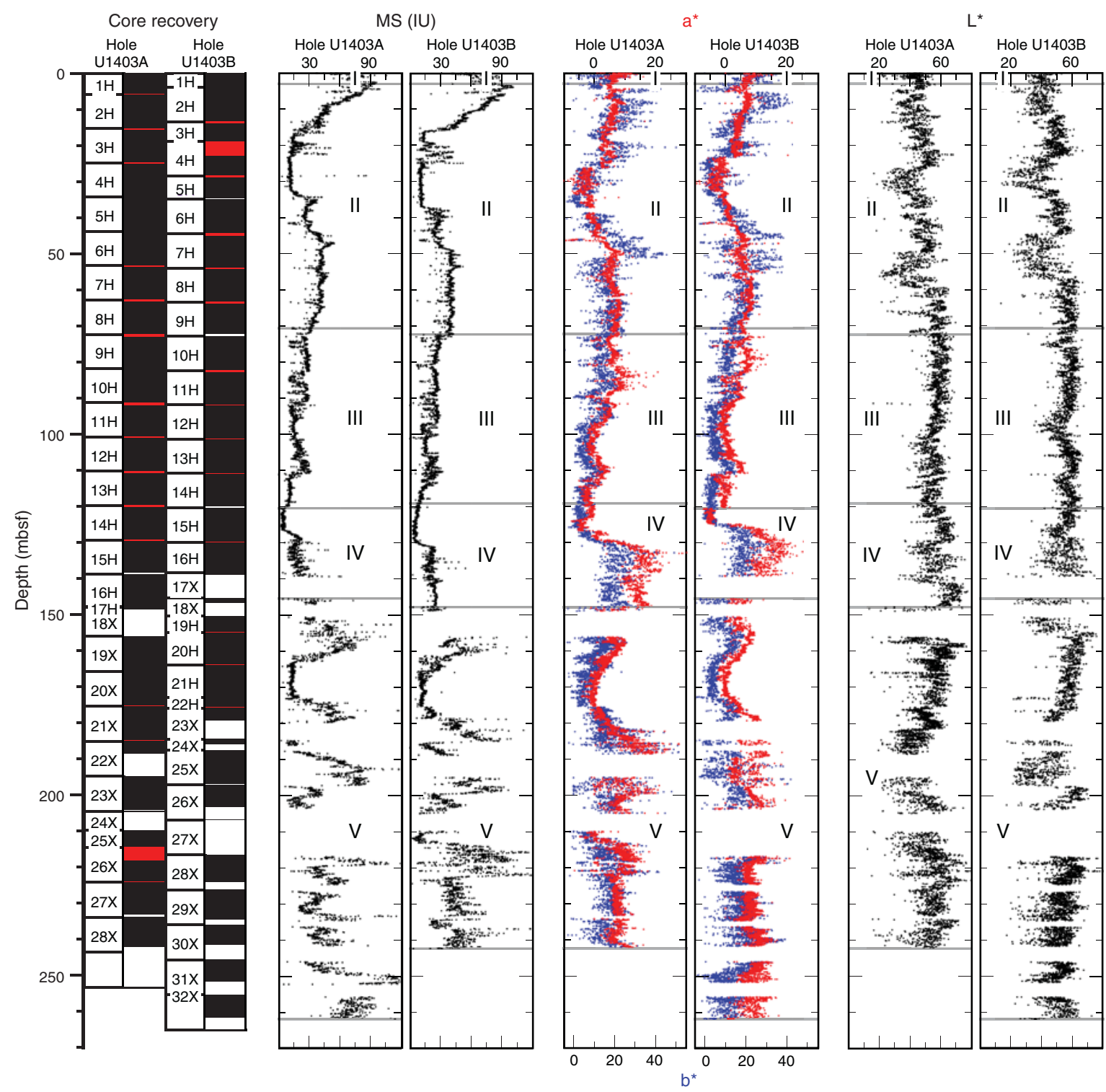

Coring system

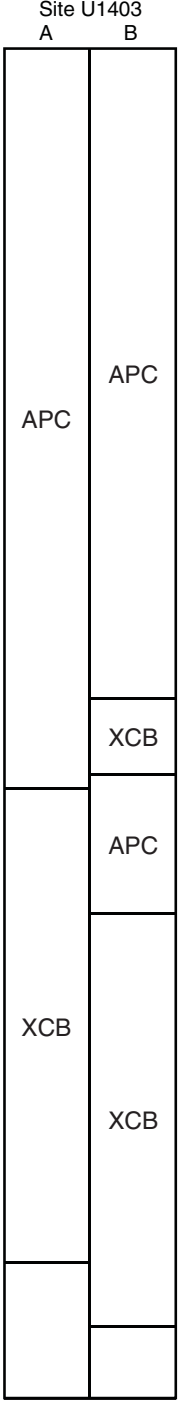


Figure F32. Plot of mbsf depth vs. CCSF depth for core tops, Site U1404. The growth factor is equal to the slope of the regression line.

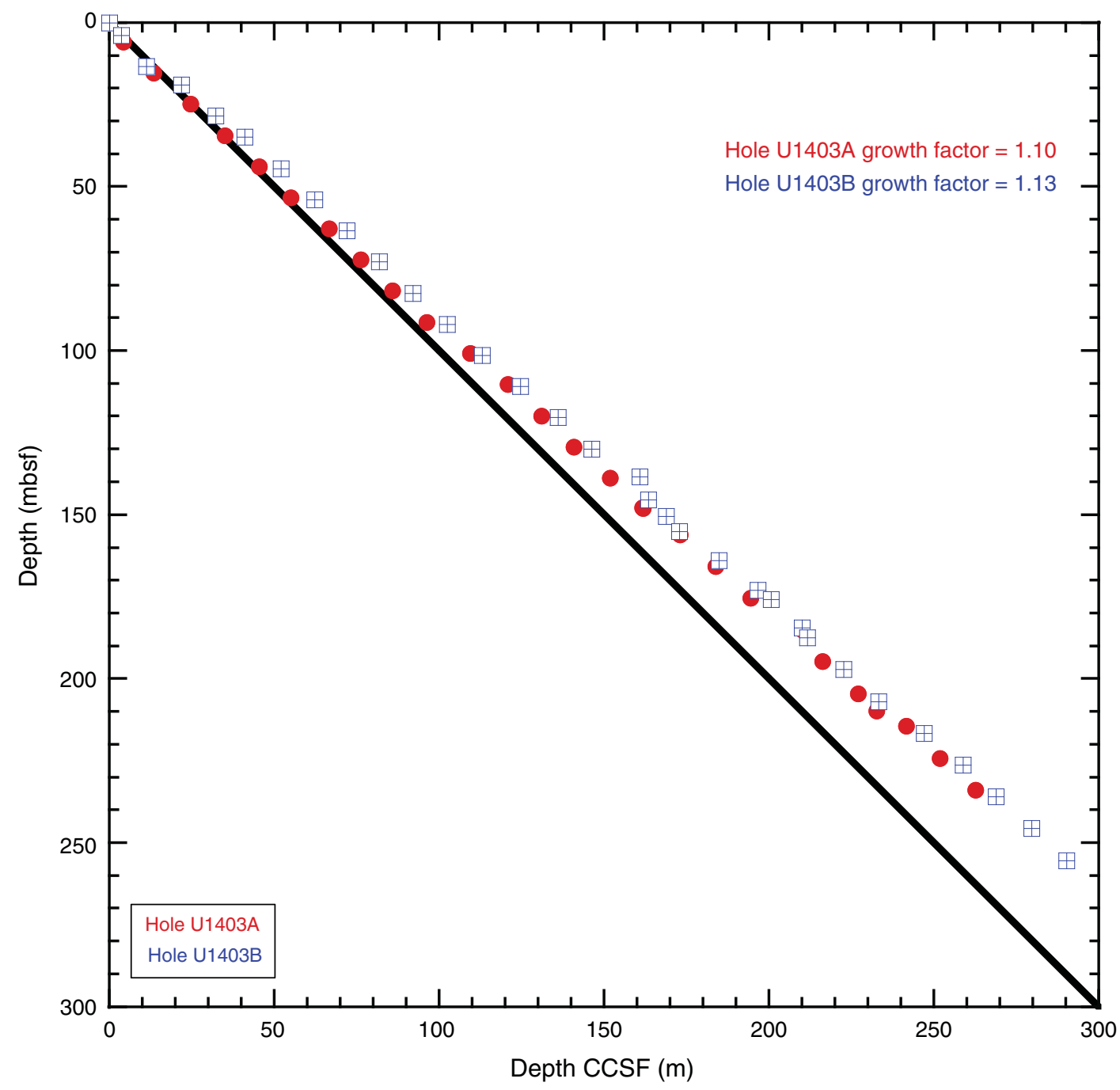


Figure F33. Plots of magnetic susceptibility, Site U1403. Top panels show the spliced section for each interval of the splice. Bottom panels show Hole U1403B data offset by 100 IU from Hole U1403A to aid visualization. Open circles indicate core tops. A. 0-50 m CCSF. (Continued on next five pages.)
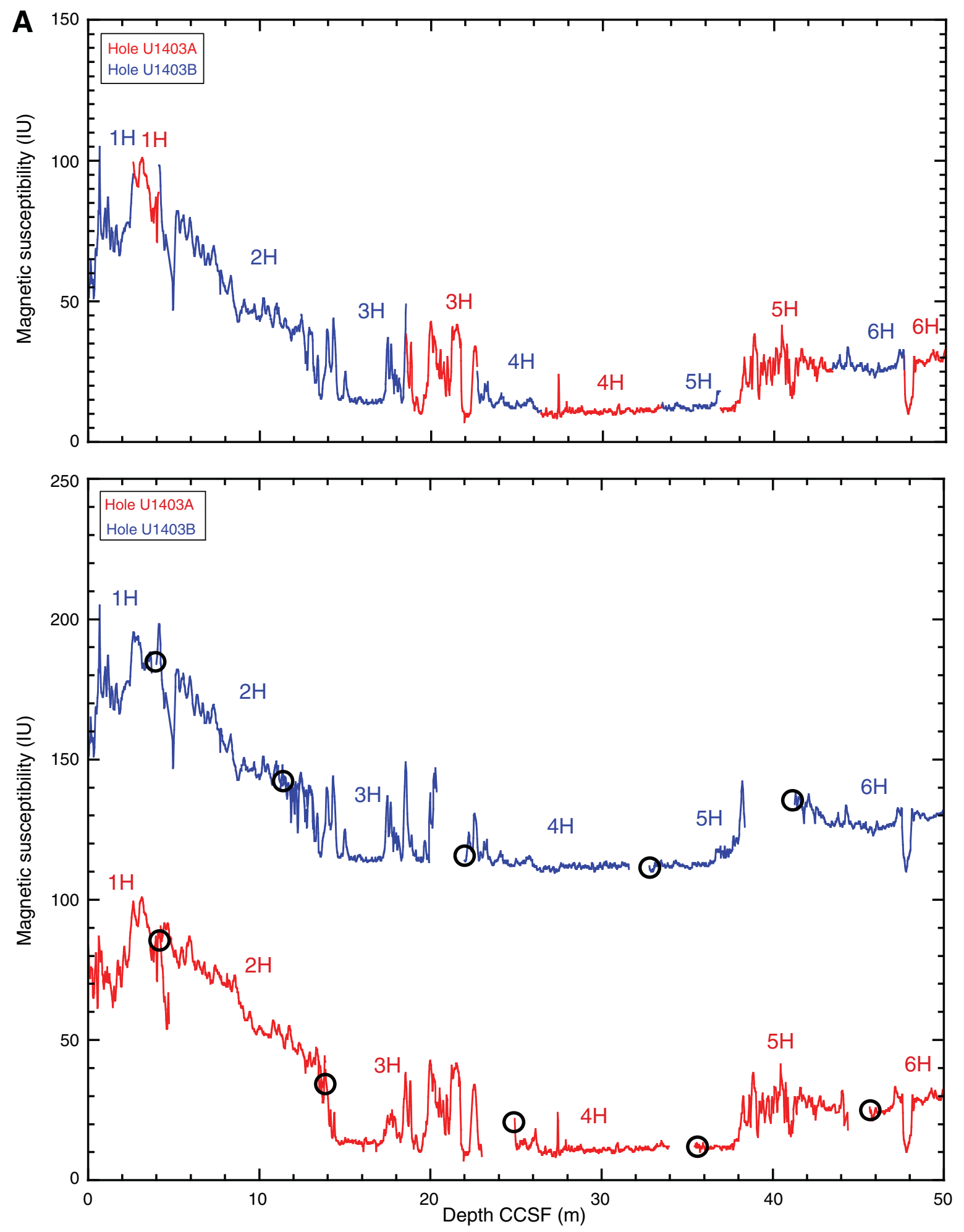
Figure F33 (continued). B. 50-100 m CCSF. (Continued on next page.)
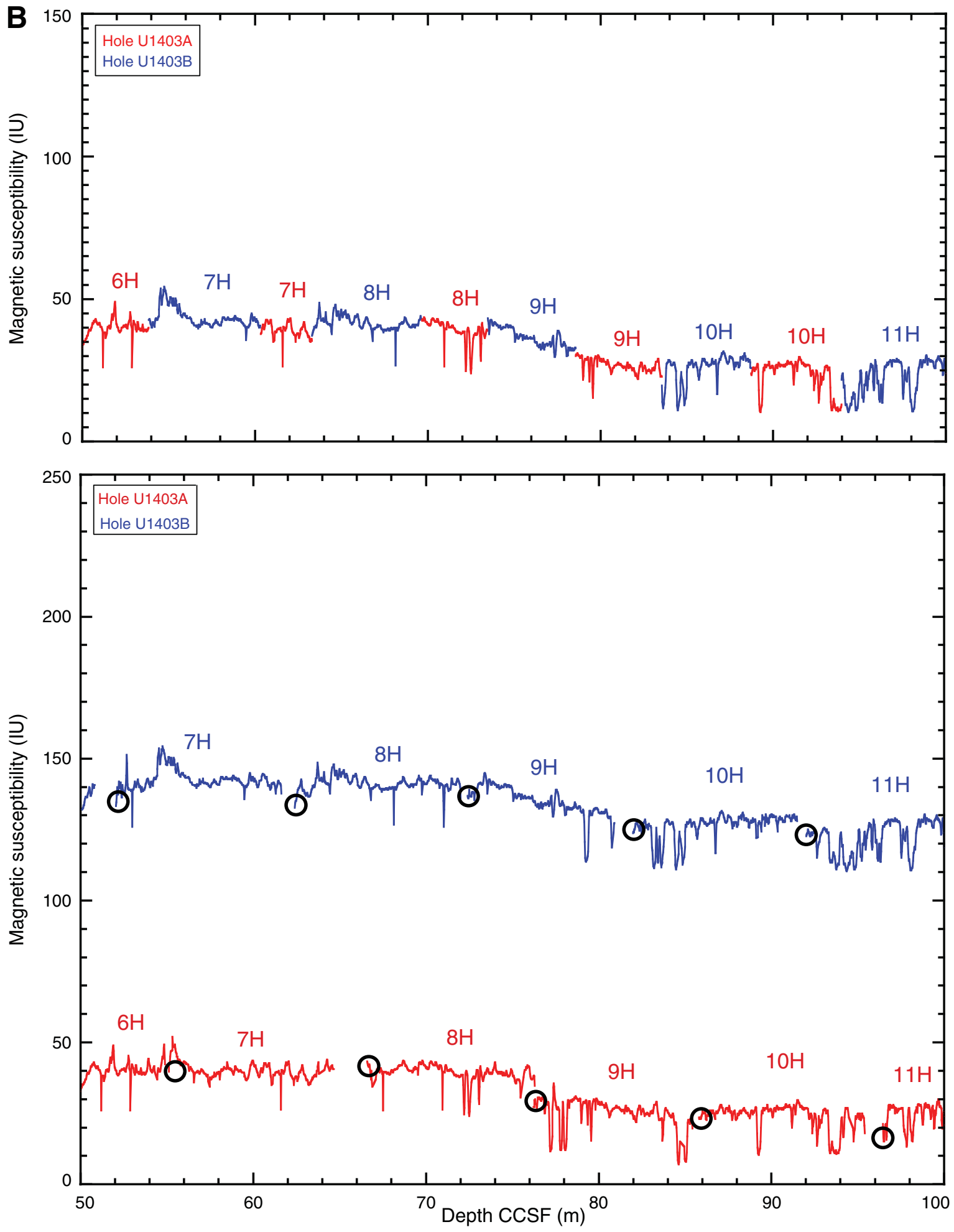
Figure F33 (continued). C. 100-150 m CCSF. (Continued on next page.)
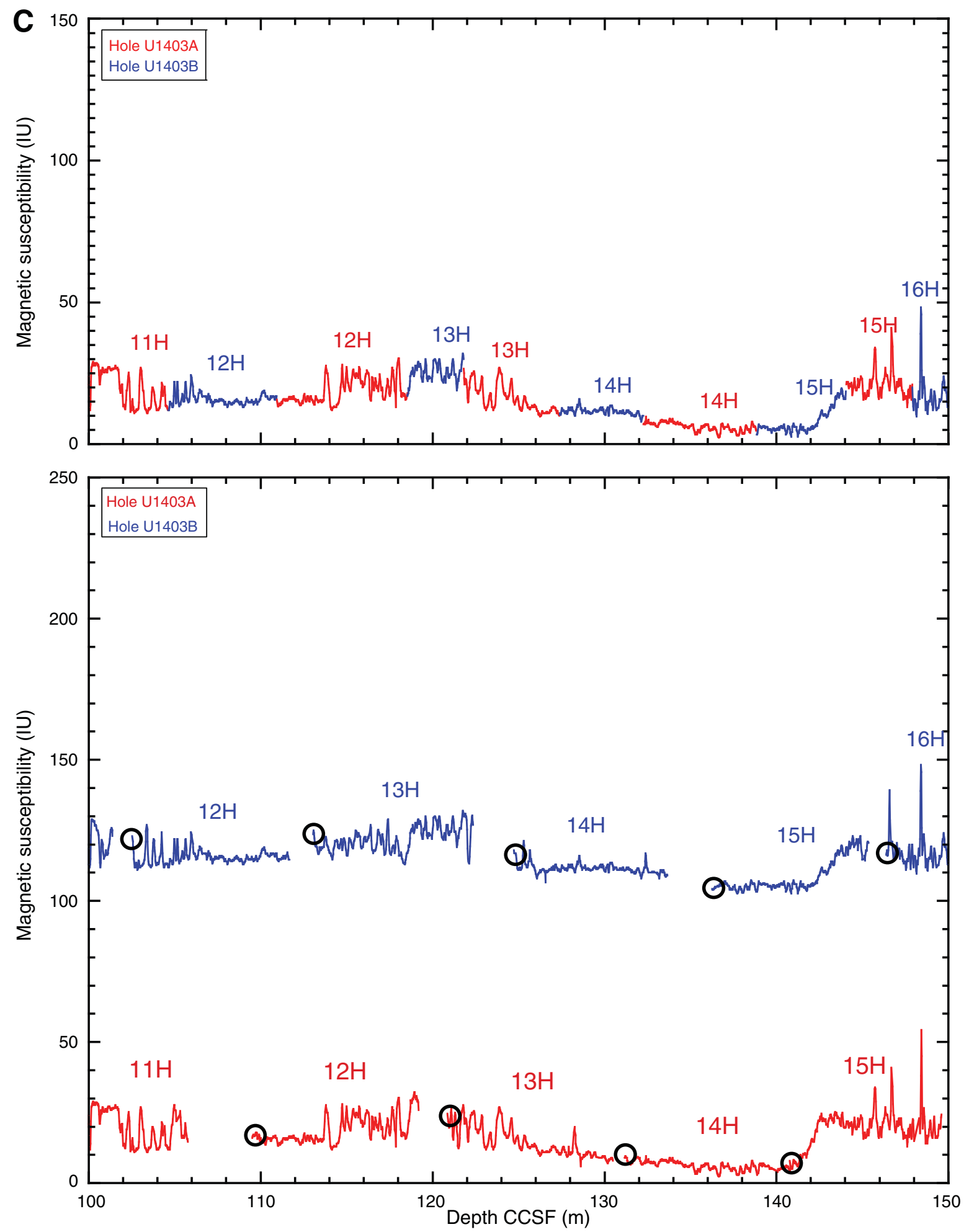
Figure F33 (continued). D. 150-200 m CCSF. (Continued on next page.)
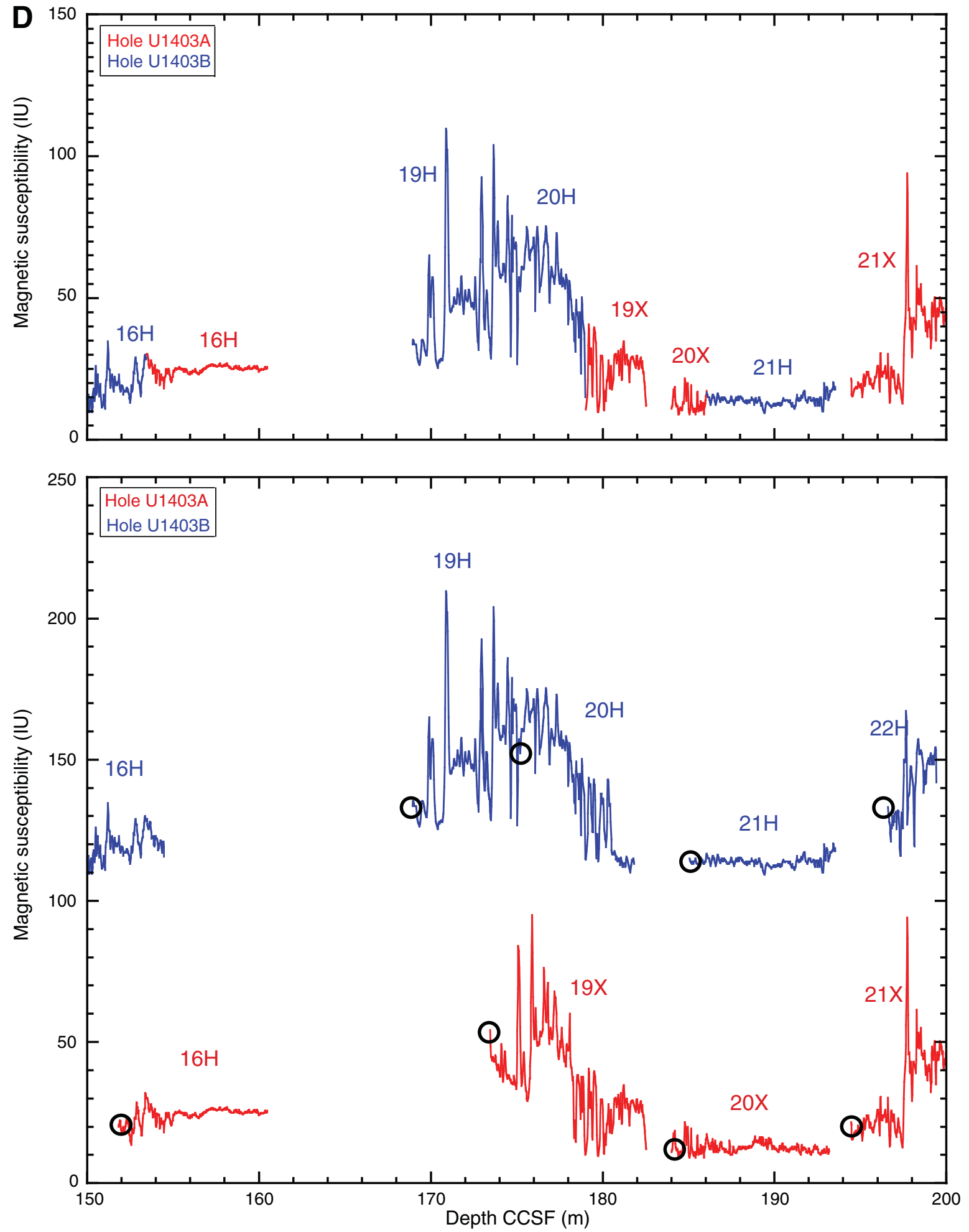
Figure F33 (continued). E. 200-250 m CCSF. (Continued on next page.)
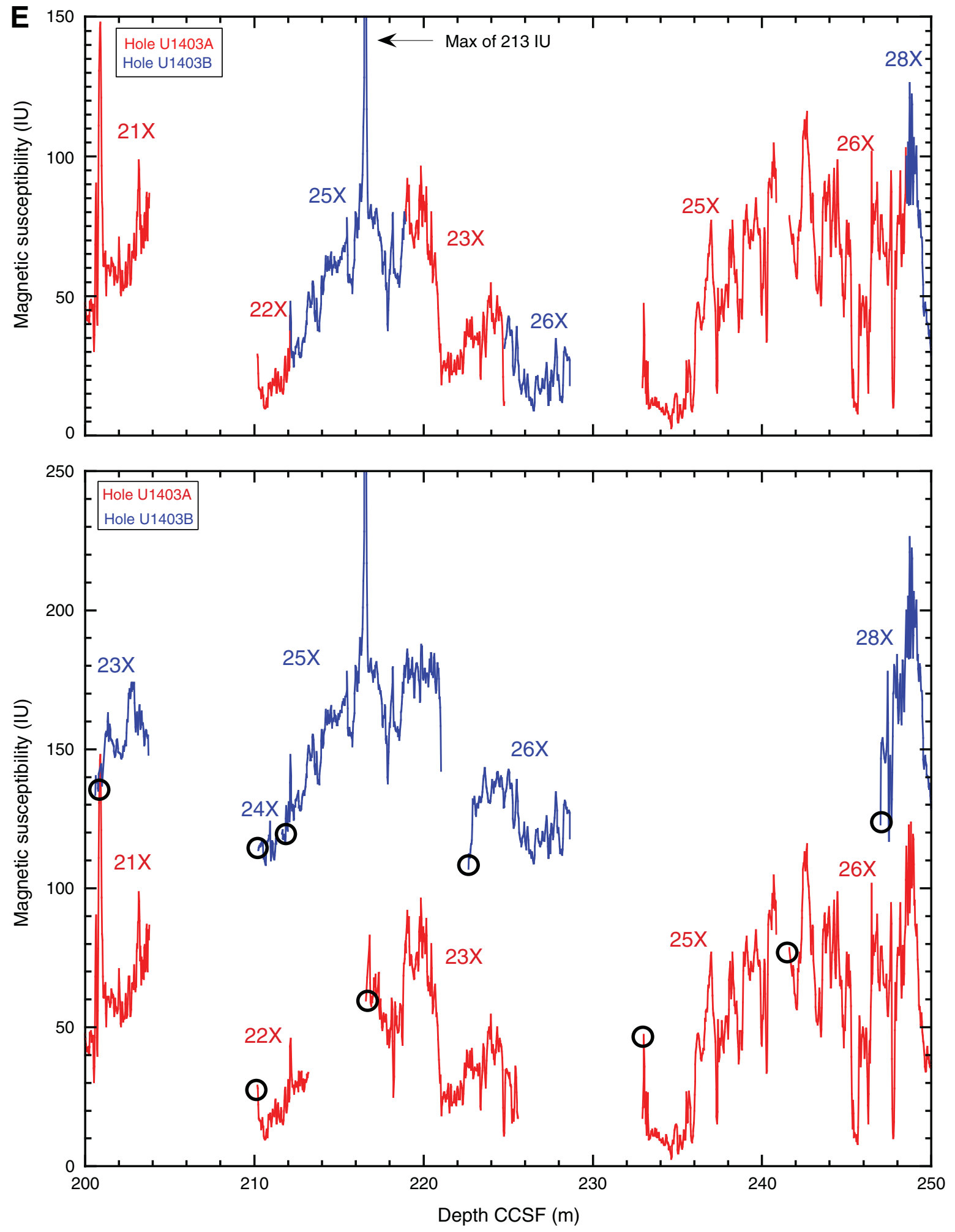
Figure F33 (continued). F. 250-300 m CCSF.
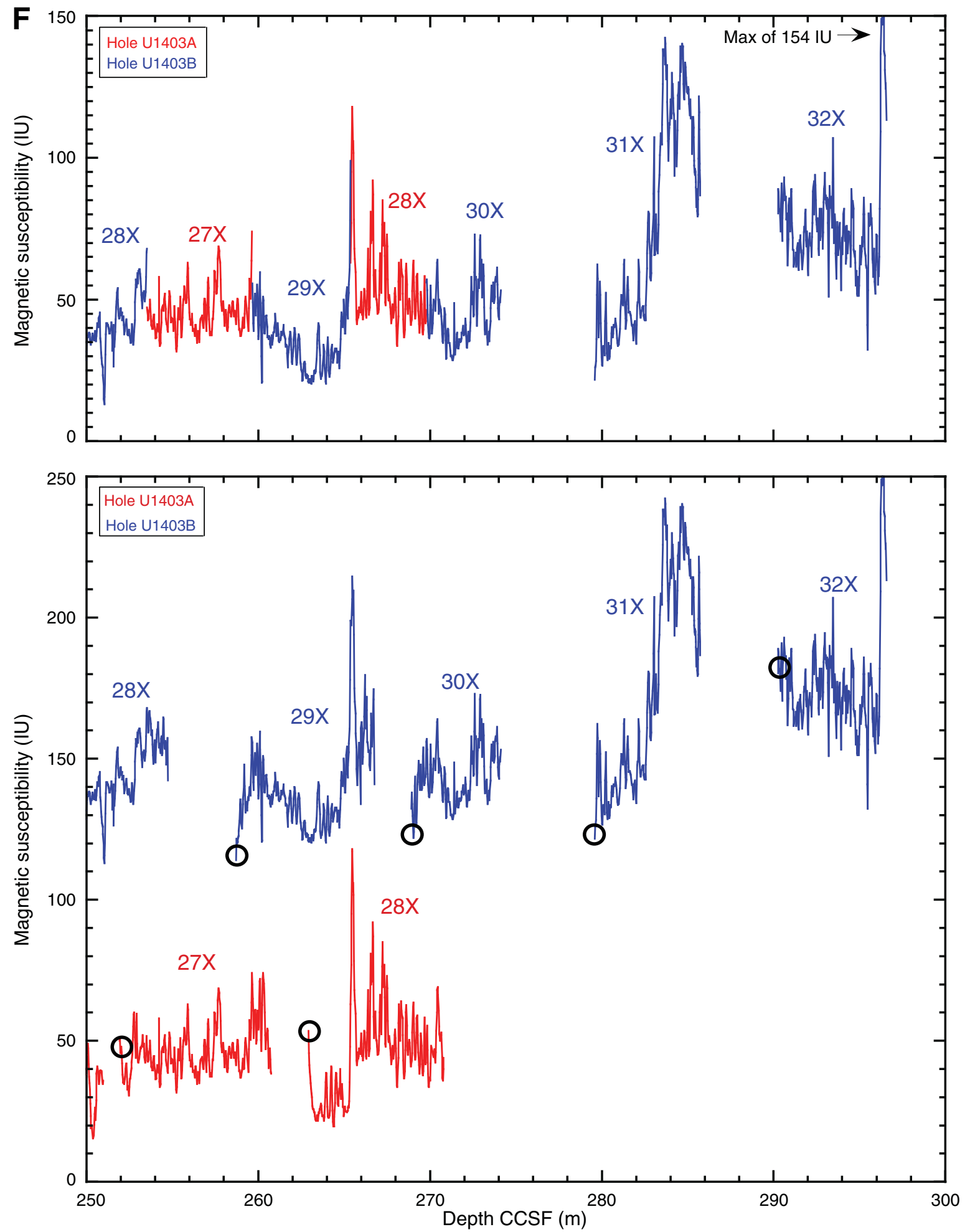
Figure F34. Plot of magnetic susceptibility data showing the ETM2 at Site U1403. Not all features overlap in the magnetic susceptibility records because of distortion in Hole U1403A; all records line up only at the tie point. A possible overlap (doubling) is present in Cores 342-U1403B-19H through $20 \mathrm{H}$. Open circles indicate core tops.

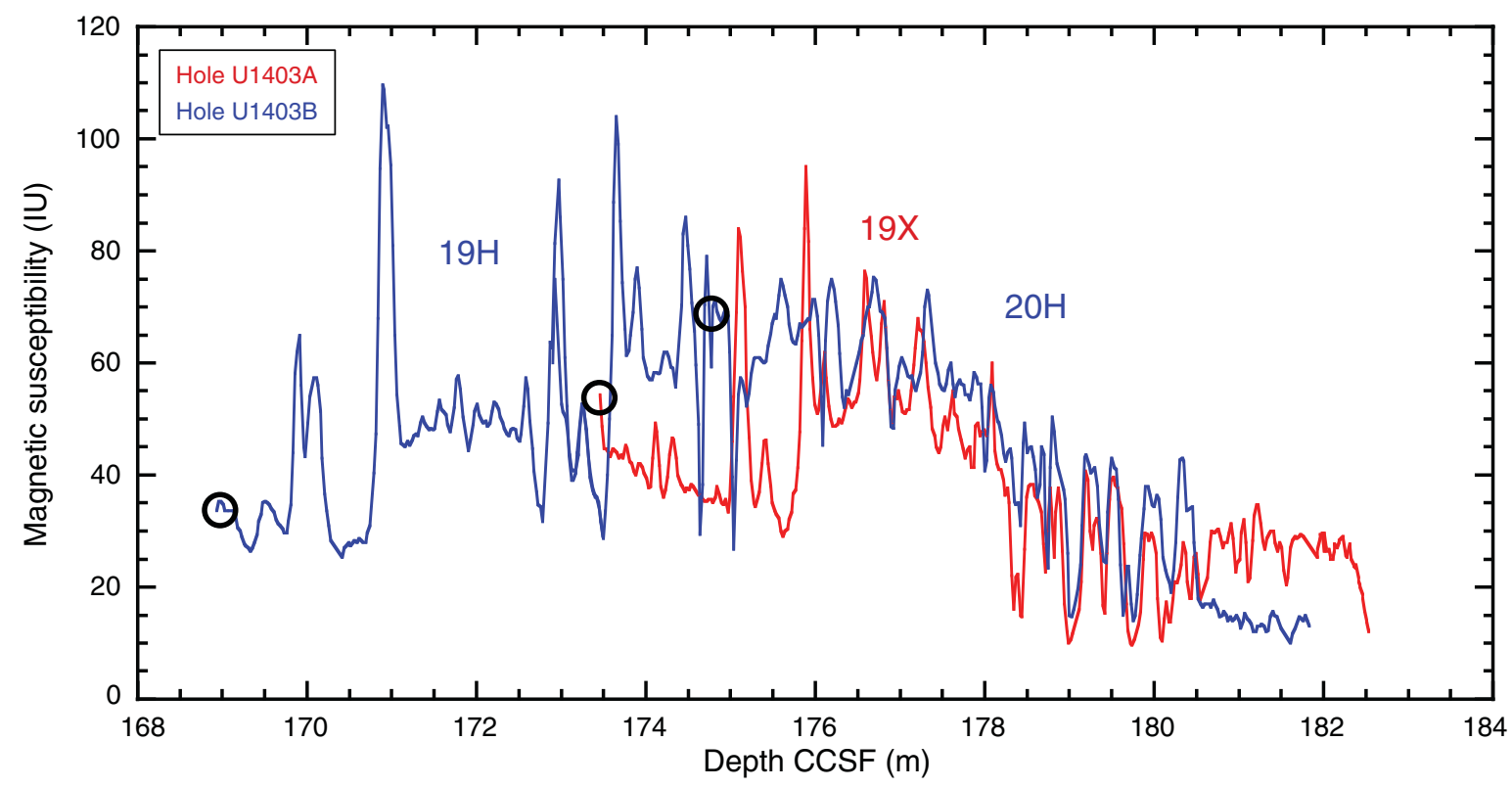


Table T1. Coring summary, Site U1403. (Continued on next page.)

\begin{tabular}{|c|c|c|c|c|c|c|c|c|c|c|}
\hline \multirow[b]{2}{*}{ Core } & \multirow[b]{2}{*}{$\begin{array}{l}\text { Date } \\
(2012)\end{array}$} & \multirow[b]{2}{*}{$\begin{array}{c}\text { Time } \\
\text { UTC } \\
\text { (h) }\end{array}$} & \multicolumn{2}{|c|}{ Depth DSF $(m)$} & \multirow[b]{2}{*}{$\begin{array}{l}\text { Interval } \\
\text { cored } \\
(\mathrm{m})\end{array}$} & \multirow[b]{2}{*}{$\begin{array}{l}\text { Curated } \\
\text { length } \\
(\mathrm{m})\end{array}$} & \multicolumn{2}{|c|}{ Depth CSF-A (m) } & \multirow[b]{2}{*}{$\begin{array}{c}\text { Recovery } \\
\text { (\%) }\end{array}$} & \multirow[b]{2}{*}{$\begin{array}{l}\text { Sections } \\
(N)\end{array}$} \\
\hline & & & $\begin{array}{l}\text { Top of } \\
\text { cored } \\
\text { interval }\end{array}$ & $\begin{array}{l}\text { Bottom } \\
\text { of cored } \\
\text { interval }\end{array}$ & & & $\begin{array}{l}\text { Top of } \\
\text { core }\end{array}$ & $\begin{array}{l}\text { Bottom of } \\
\text { core }\end{array}$ & & \\
\hline \multicolumn{11}{|c|}{ 342-U1403A- } \\
\hline $1 \mathrm{H}$ & 12 Jun & 1310 & 0.0 & 5.8 & 5.8 & 5.85 & 0.00 & 5.85 & 101 & 5 \\
\hline $2 \mathrm{H}$ & 12 Jun & 1445 & 5.8 & 15.3 & 9.5 & 9.92 & 5.80 & 15.72 & 104 & 8 \\
\hline $3 \mathrm{H}$ & 12 Jun & 1555 & 15.3 & 24.8 & 9.5 & 9.89 & 15.30 & 25.19 & 104 & 8 \\
\hline $4 \mathrm{H}$ & 12 Jun & 1700 & 24.8 & 34.3 & 9.5 & 9.54 & 24.80 & 34.34 & 100 & 8 \\
\hline $5 \mathrm{H}$ & 12 Jun & 1805 & 34.3 & 43.8 & 9.5 & 9.54 & 34.30 & 43.84 & 100 & 8 \\
\hline $6 \mathrm{H}$ & 12 Jun & 1910 & 43.8 & 53.3 & 9.5 & 9.89 & 43.80 & 53.69 & 104 & 8 \\
\hline $7 \mathrm{H}$ & 12 Jun & 2020 & 53.3 & 62.8 & 9.5 & 9.88 & 53.30 & 63.18 & 104 & 8 \\
\hline $8 \mathrm{H}$ & 12 Jun & 2130 & 62.8 & 72.3 & 9.5 & 10.21 & 62.80 & 73.01 & 107 & 8 \\
\hline $9 \mathrm{H}$ & 12 Jun & 2255 & 72.3 & 81.8 & 9.5 & 9.52 & 72.30 & 81.82 & 100 & 8 \\
\hline $10 \mathrm{H}$ & 13 Jun & 0050 & 81.8 & 91.3 & 9.5 & 10.13 & 81.80 & 91.93 & 107 & 8 \\
\hline $11 \mathrm{H}$ & 13 Jun & 0200 & 91.3 & 100.8 & 9.5 & 9.85 & 91.30 & 101.15 & 104 & 8 \\
\hline $12 \mathrm{H}$ & 13 Jun & 0310 & 100.8 & 110.3 & 9.5 & 10.09 & 100.80 & 110.89 & 106 & 8 \\
\hline $13 \mathrm{H}$ & 13 Jun & 0415 & 110.3 & 119.8 & 9.5 & 9.95 & 110.30 & 120.25 & 105 & 8 \\
\hline $14 \mathrm{H}$ & 13 Jun & 0530 & 119.8 & 129.3 & 9.5 & 9.99 & 119.80 & 129.79 & 105 & 8 \\
\hline $15 \mathrm{H}$ & 13 Jun & 0640 & 129.3 & 138.8 & 9.5 & 9.13 & 129.30 & 138.43 & 96 & 7 \\
\hline $16 \mathrm{H}$ & 13 Jun & 0800 & 138.8 & 147.8 & 9.0 & 9.00 & 138.80 & 147.80 & 100 & 7 \\
\hline $17 \mathrm{H}$ & 13 Jun & 1000 & 147.8 & 148.0 & 0.2 & 0.21 & 147.80 & 148.01 & 105 & 1 \\
\hline $18 \mathrm{X}$ & 13 Jun & 1330 & 148.0 & 156.0 & 8.0 & 0.85 & 148.00 & 148.85 & 10 & 2 \\
\hline $19 \mathrm{X}$ & 13 Jun & 1450 & 156.0 & 165.7 & 9.7 & 9.65 & 156.00 & 165.65 & 99 & 8 \\
\hline $20 x$ & 13 Jun & 1620 & 165.7 & 175.4 & 9.7 & 9.77 & 165.70 & 175.47 & 101 & 8 \\
\hline $21 x$ & 13 Jun & 1815 & 175.4 & 185.1 & 9.7 & 9.76 & 175.40 & 185.16 & 101 & 8 \\
\hline $22 x$ & 13 Jun & 2035 & 185.1 & 194.8 & 9.7 & 3.61 & 185.10 & 188.71 & 37 & 4 \\
\hline $23 x$ & 13 Jun & 2310 & 194.8 & 204.5 & 9.7 & 9.54 & 194.80 & 204.34 & 98 & 8 \\
\hline $24 X$ & 14 Jun & 0200 & 204.5 & 209.7 & 5.2 & 0.32 & 204.50 & 204.82 & 6 & 1 \\
\hline $25 X$ & 14 Jun & 0425 & 209.7 & 214.5 & 4.8 & 8.65 & 209.70 & 218.35 & 180 & 7 \\
\hline $26 x$ & 14 Jun & 0640 & 214.5 & 224.2 & 9.7 & 9.71 & 214.50 & 224.21 & 100 & 8 \\
\hline $27 x$ & 14 Jun & 0850 & 224.2 & 233.9 & 9.7 & 9.04 & 224.20 & 233.24 & 93 & 7 \\
\hline $28 \mathrm{X}$ & 14 Jun & 1100 & 233.9 & 243.6 & 9.7 & 8.40 & 233.90 & 242.30 & 87 & 7 \\
\hline \multirow[t]{2}{*}{$29 x$} & 14 Jun & 1315 & 243.6 & 253.3 & 9.7 & 0.00 & 243.60 & 243.60 & 0 & 0 \\
\hline & & & & Totals: & 253.3 & 231.89 & & & 92 & 192 \\
\hline \multicolumn{11}{|c|}{ 342-U1403B- } \\
\hline $1 \mathrm{H}$ & 14 Jun & 2030 & 0.0 & 3.9 & 3.9 & 3.90 & 0.00 & 3.90 & 100 & 4 \\
\hline $2 \mathrm{H}$ & 14 Jun & 2150 & 3.9 & 13.4 & 9.5 & 10.03 & 3.90 & 13.93 & 106 & 8 \\
\hline $3 \mathrm{H}$ & 14 Jun & 2300 & 13.4 & 18.9 & 5.5 & 9.51 & 13.40 & 22.91 & 173 & 8 \\
\hline $4 \mathrm{H}$ & 15 Jun & 0010 & 18.9 & 28.4 & 9.5 & 10.03 & 18.90 & 28.93 & 106 & 8 \\
\hline $5 \mathrm{H}$ & 15 Jun & 0115 & 28.4 & 34.9 & 6.5 & 6.41 & 28.40 & 34.81 & 99 & 6 \\
\hline $6 \mathrm{H}$ & 15 Jun & 0220 & 34.9 & 44.4 & 9.5 & 10.14 & 34.90 & 45.04 & 107 & 8 \\
\hline $7 \mathrm{H}$ & 15 Jun & 0325 & 44.4 & 53.9 & 9.5 & 9.93 & 44.40 & 54.33 & 105 & 8 \\
\hline $8 \mathrm{H}$ & 15 Jun & 0430 & 53.9 & 63.4 & 9.5 & 10.08 & 53.90 & 63.98 & 106 & 8 \\
\hline $9 \mathrm{H}$ & 15 Jun & 0535 & 63.4 & 72.9 & 9.5 & 9.10 & 63.40 & 72.50 & 96 & 7 \\
\hline $10 \mathrm{H}$ & 15 Jun & 0645 & 72.9 & 82.4 & 9.5 & 9.90 & 72.90 & 82.80 & 104 & 8 \\
\hline $11 \mathrm{H}$ & 15 Jun & 0750 & 82.4 & 91.9 & 9.5 & 9.65 & 82.40 & 92.05 & 102 & 8 \\
\hline $12 \mathrm{H}$ & 15 Jun & 0850 & 91.9 & 101.4 & 9.5 & 9.64 & 91.90 & 101.54 & 101 & 8 \\
\hline $13 \mathrm{H}$ & 15 Jun & 0950 & 101.4 & 110.9 & 9.5 & 9.71 & 101.40 & 111.11 & 102 & 8 \\
\hline $14 \mathrm{H}$ & 15 Jun & 1055 & 110.9 & 120.4 & 9.5 & 9.27 & 110.90 & 120.17 & 98 & 8 \\
\hline $15 \mathrm{H}$ & 15 Jun & 1200 & 120.4 & 129.9 & 9.5 & 9.70 & 120.40 & 130.10 & 102 & 8 \\
\hline $16 \mathrm{H}$ & 15 Jun & 1305 & 129.9 & 138.3 & 8.4 & 9.70 & 129.90 & 138.34 & 100 & 7 \\
\hline $17 X$ & 15 Jun & 1610 & 138.3 & 145.4 & 7.1 & 0.88 & 138.30 & 139.18 & 12 & 1 \\
\hline $18 \mathrm{X}$ & 15 Jun & 1830 & 145.4 & 150.4 & 5.0 & 1.61 & 145.40 & 147.01 & 32 & 2 \\
\hline $19 \mathrm{H}$ & 15 Jun & 1930 & 150.4 & 155.0 & 4.6 & 4.68 & 150.40 & 155.08 & 102 & 4 \\
\hline $20 \mathrm{H}$ & 15 Jun & 2050 & 155.0 & 164.0 & 9.0 & 9.13 & 155.00 & 164.13 & 101 & 7 \\
\hline $21 \mathrm{H}$ & 15 Jun & 2215 & 164.0 & 173.0 & 9.0 & 9.07 & 164.00 & 173.07 & 101 & 7 \\
\hline $22 \mathrm{H}$ & 15 Jun & 2340 & 173.0 & 175.9 & 2.9 & 2.97 & 173.00 & 175.97 & 102 & 3 \\
\hline $23 x$ & 16 Jun & 0200 & 175.9 & 184.5 & 8.6 & 3.67 & 175.90 & 179.57 & 43 & 4 \\
\hline $24 X$ & 16 Jun & 0415 & 184.5 & 187.5 & 3.0 & 1.62 & 184.50 & 186.12 & 54 & 2 \\
\hline $25 X$ & 16 Jun & 0640 & 187.5 & 197.2 & 9.7 & 9.51 & 187.50 & 197.01 & 98 & 7 \\
\hline $26 x$ & 16 Jun & 0930 & 197.2 & 206.9 & 9.7 & 6.38 & 197.20 & 203.58 & 66 & 5 \\
\hline $27 X$ & 16 Jun & 1145 & 206.9 & 216.6 & 9.7 & 0.23 & 206.90 & 207.13 & 2 & 1 \\
\hline $28 \mathrm{X}$ & 16 Jun & 1410 & 216.6 & 226.3 & 9.7 & 7.87 & 216.60 & 224.47 & 81 & 7 \\
\hline
\end{tabular}


Table T1 (continued).

\begin{tabular}{|c|c|c|c|c|c|c|c|c|c|c|}
\hline \multirow[b]{2}{*}{ Core } & \multirow[b]{2}{*}{$\begin{array}{l}\text { Date } \\
(2012)\end{array}$} & \multirow[b]{2}{*}{$\begin{array}{c}\text { Time } \\
\text { UTC } \\
\text { (h) }\end{array}$} & \multicolumn{2}{|c|}{ Depth DSF (m) } & \multirow[b]{2}{*}{$\begin{array}{l}\text { Interval } \\
\text { cored } \\
\text { (m) }\end{array}$} & \multirow[b]{2}{*}{$\begin{array}{l}\text { Curated } \\
\text { length } \\
\text { (m) }\end{array}$} & \multicolumn{2}{|c|}{ Depth CSF-A (m) } & \multirow[b]{2}{*}{$\begin{array}{l}\text { Recovery } \\
\text { (\%) }\end{array}$} & \multirow[b]{2}{*}{$\begin{array}{l}\text { Sections } \\
(N)\end{array}$} \\
\hline & & & $\begin{array}{c}\text { Top of } \\
\text { cored } \\
\text { interval }\end{array}$ & $\begin{array}{l}\text { Bottom } \\
\text { of cored } \\
\text { interval }\end{array}$ & & & $\begin{array}{l}\text { Top of } \\
\text { core }\end{array}$ & $\begin{array}{l}\text { Bottom of } \\
\text { core }\end{array}$ & & \\
\hline $29 x$ & 16 Jun & 1605 & 226.3 & 236.0 & 9.7 & 8.38 & 226.30 & 234.68 & 86 & 7 \\
\hline $30 x$ & 16 Jun & 1800 & 236.0 & 245.7 & 9.7 & 5.64 & 236.00 & 241.64 & 58 & 5 \\
\hline $31 x$ & 16 Jun & 2000 & 245.7 & 255.4 & 9.7 & 6.22 & 245.70 & 251.92 & 64 & 5 \\
\hline \multirow[t]{3}{*}{$32 X$} & 16 Jun & 2230 & 255.4 & 265.1 & 9.7 & 6.51 & 255.40 & 261.91 & 67 & 6 \\
\hline & & & & Totals: & 265.1 & 231.07 & & & 87 & 193 \\
\hline & & & \multicolumn{2}{|c|}{ Site U1403 totals: } & 518.4 & 462.96 & & & 90 & 385 \\
\hline
\end{tabular}

DSF = drilling depth below seafloor, CSF-A = core depth below seafloor, method $\mathrm{A} . \mathrm{H}=$ advanced piston core, $\mathrm{X}=$ extended core barrel core.

Table T2. Lithostratigraphic unit intervals, Site U1403.

\begin{tabular}{|c|c|c|c|c|}
\hline \multirow{2}{*}{$\begin{array}{l}\text { Lith. } \\
\text { unit }\end{array}$} & \multicolumn{2}{|c|}{ Core, section, interval $(\mathrm{cm})$} & \multicolumn{2}{|c|}{ Depth (mbsf) } \\
\hline & Top & Bottom & Top & Bottom \\
\hline & 342-U1403A- & 342-U1403A- & & \\
\hline 1 & $1 \mathrm{H}-1,0$ & $1 \mathrm{H}-2,150$ & 0.00 & 3.00 \\
\hline II & $1 \mathrm{H}-3,0$ & $8 \mathrm{H}-\mathrm{CC}, 43$ & 3.00 & 72.30 \\
\hline III & $9 \mathrm{H}-1,0$ & $12 \mathrm{H}-\mathrm{CC}, 34$ & 72.30 & 119.14 \\
\hline IV & $13 \mathrm{H}-7,0$ & $17 \mathrm{H}-\mathrm{CC}, 23$ & 119.14 & 147.80 \\
\hline $\mathrm{Va}$ & $18 \mathrm{H}-1,0$ & $26 X-5,12$ & 147.80 & 220.62 \\
\hline $\mathrm{Vb}$ & $26 X-5,12$ & $28 \mathrm{X}-\mathrm{CC}, 29$ & 220.62 & 242.30 \\
\hline & 342-U1403B- & 342-U1403B- & & \\
\hline 1 & $1 \mathrm{H}-1,0$ & $1 \mathrm{H}-2,150$ & 0.00 & 3.00 \\
\hline II & $1 \mathrm{H}-3,0$ & $9 \mathrm{H}-5,124$ & 3.00 & 70.64 \\
\hline III & $9 \mathrm{H}-5,124$ & $14 \mathrm{H}-\mathrm{CC}, 23$ & 70.64 & 120.40 \\
\hline IV & $15 \mathrm{H}-1,0$ & $17 X-1,88$ & 120.40 & 145.40 \\
\hline Va & $18 X-1,0$ & $28 X-1,46.5$ & 145.40 & 217.07 \\
\hline $\mathrm{Vb}$ & $28 \mathrm{X}-1,46.5$ & $32 \mathrm{X}-\mathrm{CC}, 12$ & 217.07 & 261.76 \\
\hline
\end{tabular}


Table T3. Calcareous nannofossil datums, Site U1403.

\begin{tabular}{|c|c|c|c|c|c|c|c|c|c|}
\hline \multicolumn{2}{|c|}{ Hole, core, section, interval $(\mathrm{cm})$} & \multirow[b]{2}{*}{ Age } & \multirow{2}{*}{$\begin{array}{l}\text { Zone/ } \\
\text { Subzone }\end{array}$} & \multirow[b]{2}{*}{ Marker species } & \multirow{2}{*}{$\begin{array}{l}\text { Age } \\
(\mathrm{Ma})\end{array}$} & \multicolumn{4}{|c|}{ Depth (mbsf) } \\
\hline Top & Bottom & & & & & Top & Bottom & Mid-point & \pm \\
\hline $342-$ & $342-$ & & & & & & & & \\
\hline $11403 \mathrm{~A}_{-1} \mathrm{H}_{-1} 45$ & $11403 \mathrm{~A}_{-1} \mathrm{H}_{-1} 130$ & Pleistocene-Holocene & $N N 20$ & T Pseudoemiliania lacunosa & 044 & & & & 0.43 \\
\hline $\begin{array}{l}\text { U1403A-1H-1, } 45 \\
\text { U1403A-1H-1, } 130\end{array}$ & $\begin{array}{l}\text { U1 } 403 \mathrm{~A}-\mathrm{TH}-1,130 \\
\text { U1403A-1H-2, } 45\end{array}$ & & NN20 & $\begin{array}{l}\text { I Pseudoemilliania lacunosa } \\
\text { T Calcidiscus macintyrei }\end{array}$ & $\begin{array}{l}0.44 \\
1.61\end{array}$ & $\begin{array}{l}0.45 \\
1.30\end{array}$ & $\begin{array}{l}1.30 \\
1.95\end{array}$ & $\begin{array}{l}0.88 \\
1.63\end{array}$ & $\begin{array}{l}0.43 \\
0.33\end{array}$ \\
\hline U1403A-1H-2, 45 & U1403A-1H-2, 70 & & NN19 & T Discoaster brouweri & 1.93 & 1.95 & 2.20 & 2.08 & 0.13 \\
\hline & & Eocene & & & & & & & \\
\hline U1403A-13H-6, 100 & U1403A-13H-7, 25 & & NP15a & T Discoaster sublodoensis & 46.29 & 118.68 & 119.39 & 119.04 & 0.35 \\
\hline U1403A-15H-1, 39 & U1403A-15H-2, 90 & & & B Nannotetrina cristata & 47.73 & 129.69 & 131.70 & 130.70 & 1.00 \\
\hline U1403A-15H-4, 75 & U1403A-15H-5, 86 & & NP14 & B Discoaster sublodoensis & 49.11 & 134.55 & 136.16 & 135.36 & 0.80 \\
\hline U1403A-16H-CC & U1403A-17H-CC & & NP13 & T Tribrachiatus orthostylus & 50.50 & 147.75 & 147.80 & 147.78 & 0.03 \\
\hline U1403A-18X-CC & U1403A-19X-1, 46 & & NP12 & B Discoaster lodoensis & 53.70 & 148.76 & 156.46 & 152.61 & 3.85 \\
\hline U1403A-19X-3, 51 & U1403A-19X-4, 38 & & NP11 & T Tribrachiatus contortus & 54.17 & 159.10 & 160.88 & 159.99 & 0.89 \\
\hline U1403A-19X-CC & U1403A-20X-1, 78 & & & B Tribrachiatus orthostylus & 54.40 & 165.60 & 166.48 & 166.04 & 0.44 \\
\hline U1403A-21X-1, 88 & U1403A-21X-2, 28 & & & B Discoaster diastypus & 54.95 & 176.28 & 177.18 & 176.73 & 0.45 \\
\hline U1403A-20X-1,78 & U1403A-20X-2, 10 & & & B Tribrachiatus contortus & 54.95 & 166.48 & 167.30 & 166.89 & 0.41 \\
\hline U1403A-21X-2, 88 & U1403A-21X-3, 28 & & & T Fasciculithus spp. & 55.64 & 177.78 & 178.68 & 178.23 & 0.45 \\
\hline U1403A-21X-1, 88 & U1403A-21X-2, 28 & & NP10 & B Rhomboaster bramlettei & 55.86 & 176.28 & 177.18 & 176.73 & 0.45 \\
\hline U1403A-21X-5, 28 & U1403A-21X-5, 83 & $\begin{array}{l}\text { Paleocene/Eocene boundary } \\
\text { Paleocene }\end{array}$ & & B Rhomboaster spp. & 55.96 & 181.68 & 182.23 & 181.96 & 0.27 \\
\hline U1403B-26X-CC & U1403B-26X-CC & & & B Sphenolithus moriformis & 61.98 & 203.40 & 203.40 & 203.40 & 0.00 \\
\hline U1403A-25-1, 115 & U1403A-25-5, 75 & & & B Fasciculithus first radiation & 62.13 & 210.85 & 216.45 & 213.65 & 2.80 \\
\hline- & - & & NP4 & B Ellipsolithus macellus & 63.25 & - & - & - & - \\
\hline U1403A-26X-2, 20 & U1403A-26X-3, 84 & & & B Prinsius tenuiculus* & 64.81 & 216.20 & 218.34 & 217.27 & 1.07 \\
\hline U1403A-25X-CC & U1403A-26X-1, 20 & & NP3 & B Chiasmolithus danicus & 64.81 & 214.70 & 218.3 & 216.50 & 1.80 \\
\hline U1403A-25-1, 115 & U1403A-25-1, 115 & & & B Cruciplacolithus tenuis & 65.47 & 210.85 & 210.85 & 210.85 & 0.00 \\
\hline U1403A-26X-3, 84 & U1403A-26X-4, 74 & & NP2 & B Cruciplacolithus intermedius & 65.47 & 218.34 & 219.74 & 219.04 & 0.70 \\
\hline U1403A-26X-4, 74 & U1403A-26X-5, 3 & & & B Cruciplacolithus primus $(3.5-5 \mu \mathrm{m})$ & 65.76 & 219.74 & 220.53 & 220.14 & 0.39 \\
\hline U1403A-26X-5, 3 & U1403A-26X-5, 5 & & & B Neobiscutum parvulum & 65.90 & 220.53 & 220.55 & 220.54 & 0.01 \\
\hline U1403A-26X-5, 9 & U1403A-26X-5, 13 & Cretaceous/Paleogene boundary & & T Micula murus, other Cretaceous taxa & 66.04 & 220.59 & 220.63 & 220.61 & 0.02 \\
\hline U1403A-26X-5, 9 & U1403A-26X-5, 13 & $\begin{array}{l}\text { Cretaceous/Paleogene boundary } \\
\text { Maastrichtian }\end{array}$ & & B Biantholithus sparsus; Ba calcispheres & 66.04 & 220.59 & 220.63 & 220.61 & 0.02 \\
\hline U1403B-28X-3, 50 & U1403B-28X-5, 50 & & UC20dT & B Micula prinsii & 67.30 & 220.10 & 223.10 & 221.60 & 1.50 \\
\hline U1403B-28X-5, 50 & U1403B-28X-CC & & UC20cT & B Ceratolithoides kamptneri & 67.84 & 223.10 & 224.42 & 223.76 & 0.66 \\
\hline U1403B-30X-4, 40 & U1403B-30X-CC & & UC20bT & B Micula murus & 69.00 & 240.90 & 242.25 & 241.58 & 0.67 \\
\hline U1403B-29X-CC & U1403B-30X-4, 40 & & UC20bT & B Cribrocorona gallica & 69.00 & 234.63 & 240.90 & 237.77 & 3.14 \\
\hline U1403B-31X-2, 61 & U1403B-31X-3, 52 & & UC19 & T Reinhardtites levis & 70.14 & 247.81 & 249.22 & 248.52 & 0.70 \\
\hline & & Campanian & & & & & & & \\
\hline U1403B-31X-3, 52 & U1403B-31X-4, 18 & & $\sim$ UC18 & T Uniplanarius trifidus & 71.31 & 249.22 & 250.38 & 249.80 & 0.58 \\
\hline U1403B-31X-3, 52 & U1403B-31X-4, 18 & & UC17 & T Broinsonia parca constricta & 72.02 & 249.22 & 250.38 & 249.80 & 0.58 \\
\hline U1403B-32X-3, 28 & U1403B-32X-3, 28 & & UC15dT & B Uniplanarius trifidus & 76.82 & 258.68 & 258.68 & 258.68 & 0.00 \\
\hline
\end{tabular}

* $=$ interpolated age. $\mathrm{B}=$ base, $\mathrm{Ba}=$ base of acme, $\mathrm{T}=$ top. $-=$ barren sample.

Table T4. Calcareous nannofossil distribution, Site U1403. This table is available in an oversized format. 
Table T5. Radiolarian datums, Site U1403.

\begin{tabular}{|c|c|c|c|c|c|c|c|c|c|}
\hline \multicolumn{2}{|c|}{ Hole, core, section, interval $(\mathrm{cm})$} & \multirow[b]{2}{*}{ Age } & \multirow{2}{*}{$\begin{array}{l}\text { Zone/ } \\
\text { Subzone }\end{array}$} & \multirow[b]{2}{*}{ Marker species } & \multirow{2}{*}{$\begin{array}{c}\text { Age } \\
(\mathrm{Ma})\end{array}$} & \multicolumn{4}{|c|}{ Depth (mbsf) } \\
\hline Top & Bottom & & & & & Top & Bottom & Mid-point & \pm \\
\hline $342-$ & $342-$ & Eocene & & & & & & & \\
\hline U1403A-12H-CC & U1403A-13H-CC & & & B Sethochytris triconiscus & 42.69 & 110.87 & 120.23 & 115.55 & 4.68 \\
\hline U1403B-8H-CC & U1403B-9H-3, 50-52 & & & B Podocyrtis fasciolata & 44.25 & 63.98 & 66.91 & 65.45 & 1.47 \\
\hline U1403B-8H-CC & U1403B-9H-3, 50-52 & & RP13 & B Eusyringium fistuligerum & 44.46 & 63.98 & 66.91 & 65.45 & 1.47 \\
\hline U1403A-11H-CC & U1403A-12H-CC & & & T Podocyrtis diamesa & 45.63 & 101.13 & 110.87 & 106.00 & 4.87 \\
\hline U1403A-12H-CC & U1403A-13H-CC & & & T Theocotyle nigriniae & 45.63 & 110.87 & 120.23 & 115.55 & 4.68 \\
\hline U1403A-9H-CC & U1403A-10H-CC & & & T Thyrsocyrtis hirsuta & 45.63 & 81.80 & 91.91 & 86.85 & 5.06 \\
\hline U1403A-10H-CC & U1403A-11H-CC & & & $\mathrm{X}$ Thyrsocyrtis tensa $-T$. triacantha & 46.21 & 91.91 & 101.13 & 96.52 & 4.61 \\
\hline U1403A-11H-CC & U1403A-12H-CC & & RP12 & B Eusyringium lagena & 46.21 & 101.13 & 110.87 & 106.00 & 4.87 \\
\hline U1403A-12H-CC & U1403A-13H-CC & & RP11 & B Dictyoprora mongolfieri & 47.98 & 110.87 & 120.23 & 115.55 & 4.68 \\
\hline U1403A-13H-CC & U1403A-14H-CC & & RP10 & $\mathrm{X}$ Theocotyle nigriniae $-\mathrm{T}$. cryptocephala & 48.57 & 120.23 & 129.77 & 125.00 & 4.77 \\
\hline U1403A-16H-CC & U1403A-17H-CC & & & B Thyrsocyrtis rhizodon & 49.46 & 147.78 & 147.83 & 147.80 & 0.02 \\
\hline U1403A-15H-CC & U1403A-16H-CC & & & B Podocyrtis diamesa & 49.75 & 138.41 & 147.78 & 143.09 & 4.69 \\
\hline U1403A-13H-CC & U1403A-14H-CC & & & B Theocorys anaclasta & 50.05 & 120.23 & 129.77 & 125.00 & 4.77 \\
\hline U1403A-18H-CC & U1403A-19H-CC & & RP09 & B Lychnocanoma bellum & 50.05 & 148.77 & 165.63 & 157.20 & 8.43 \\
\hline U1403A-19H-CC & U1403A-20H-CC & & & T Bekoma bidartensis & 50.87 & 165.63 & 175.45 & 170.54 & 4.91 \\
\hline U1403A-18H-CC & U1403A-19H-CC & & & T Buryella tetradica & 50.87 & 148.77 & 165.63 & 157.20 & 8.43 \\
\hline U1403A-14H-CC & U1403A-15H-CC & & & B Thyrsocyrtis tensa & 51.70 & 129.77 & 138.41 & 134.09 & 4.32 \\
\hline U1403A-15H-CC & U1403A-16H-CC & & & B Heocotylissa ficus & 51.70 & 138.41 & 147.78 & 143.09 & 4.69 \\
\hline U1403A-15H-CC & U1403A-16H-CC & & & B Calocyclas hispida & 52.52 & 138.41 & 147.78 & 143.09 & 4.69 \\
\hline U1403A-16H-CC & U1403A-17H-CC & & & B Spongatractus balbis & 53.35 & 147.78 & 147.83 & 147.80 & 0.02 \\
\hline U1403A-16H-CC & U1403A-17H-CC & & & B Theocotyle nigriniae & 53.35 & 147.78 & 147.83 & 147.80 & 0.02 \\
\hline U1403A-19H-CC & U1403A-20H-CC & & RP08 & B Thyrsocyrtis hirsuta & 53.35 & 165.63 & 175.45 & 170.54 & 4.91 \\
\hline U1403A-19H-CC & U1403A-20H-CC & & & B Calocycloma castum & 55.40 & 165.63 & 175.45 & 170.54 & 4.91 \\
\hline U1403A-18H-CC & U1403A-19H-CC & & & T Amphisphaera goruna & 55.50 & 148.77 & 165.63 & 157.20 & 8.43 \\
\hline U1403A-21H-CC & U1403A-22H-CC & & & B Theocorys phyzella & 55.90 & 185.14 & 188.69 & 186.91 & 1.78 \\
\hline U1403A-21H-CC & U1403A-22H-CC & & RP07b & B Podocyrtis papalis & 55.96 & 185.14 & 188.69 & 186.91 & 1.78 \\
\hline & & Paleocene & & & & & & & \\
\hline U1403A-21H-CC & U1403A-22H-CC & & & B Amphicraspedum prolixum & 56.14 & 185.14 & 188.69 & 186.91 & 1.78 \\
\hline U1403A-20H-CC & U1403A-21H-CC & & RP07a & B Bekoma bidartensis & 58.23 & 175.45 & 185.14 & 180.29 & 4.84 \\
\hline U1403A-22H-CC & U1403A-23H-CC & & RP05 & B Buryella tetradica & 62.20 & 204.32 & 204.32 & 204.32 & \\
\hline U1403A-23H-CC & U1403A-24H-CC & & & B Amphisphaera coronata & 63.00 & 204.32 & 204.32 & 204.32 & \\
\hline
\end{tabular}

$B=$ base,$T=$ top,$X=$ faunal crossover $(>50 \%$ descendent $)$. 


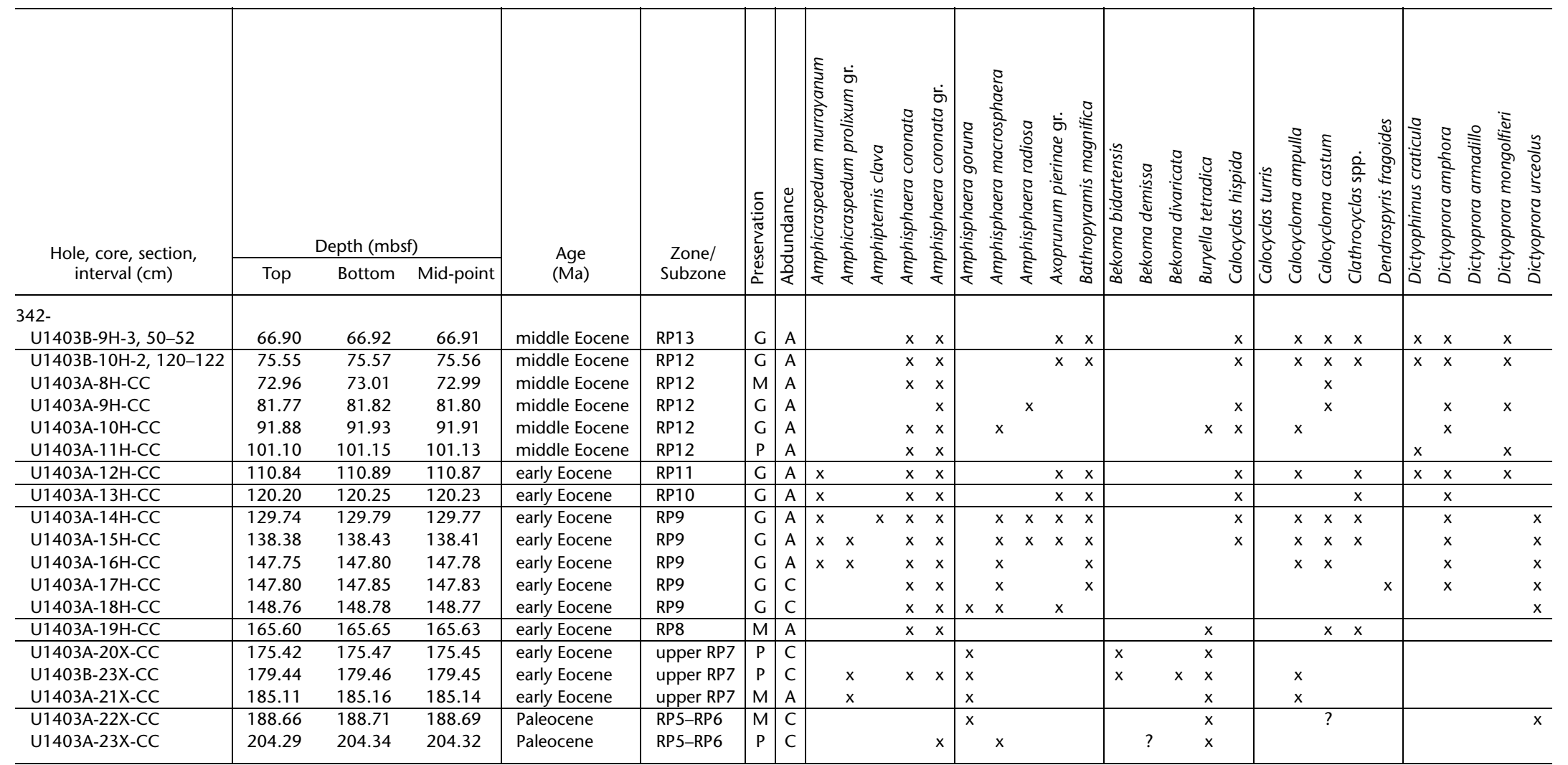

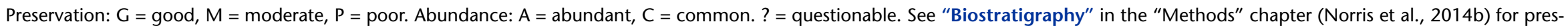
ervation and abundance definitions. 


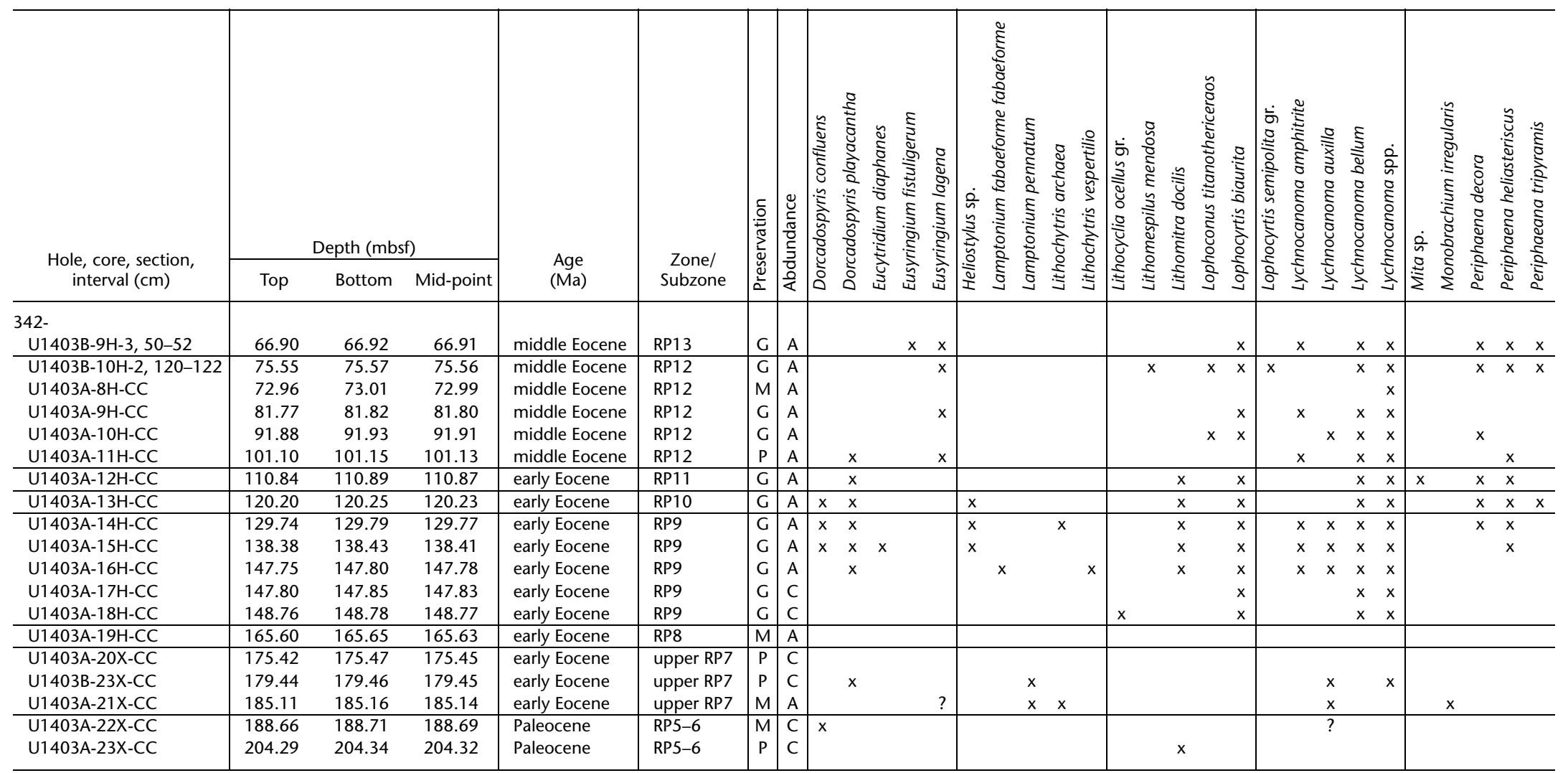




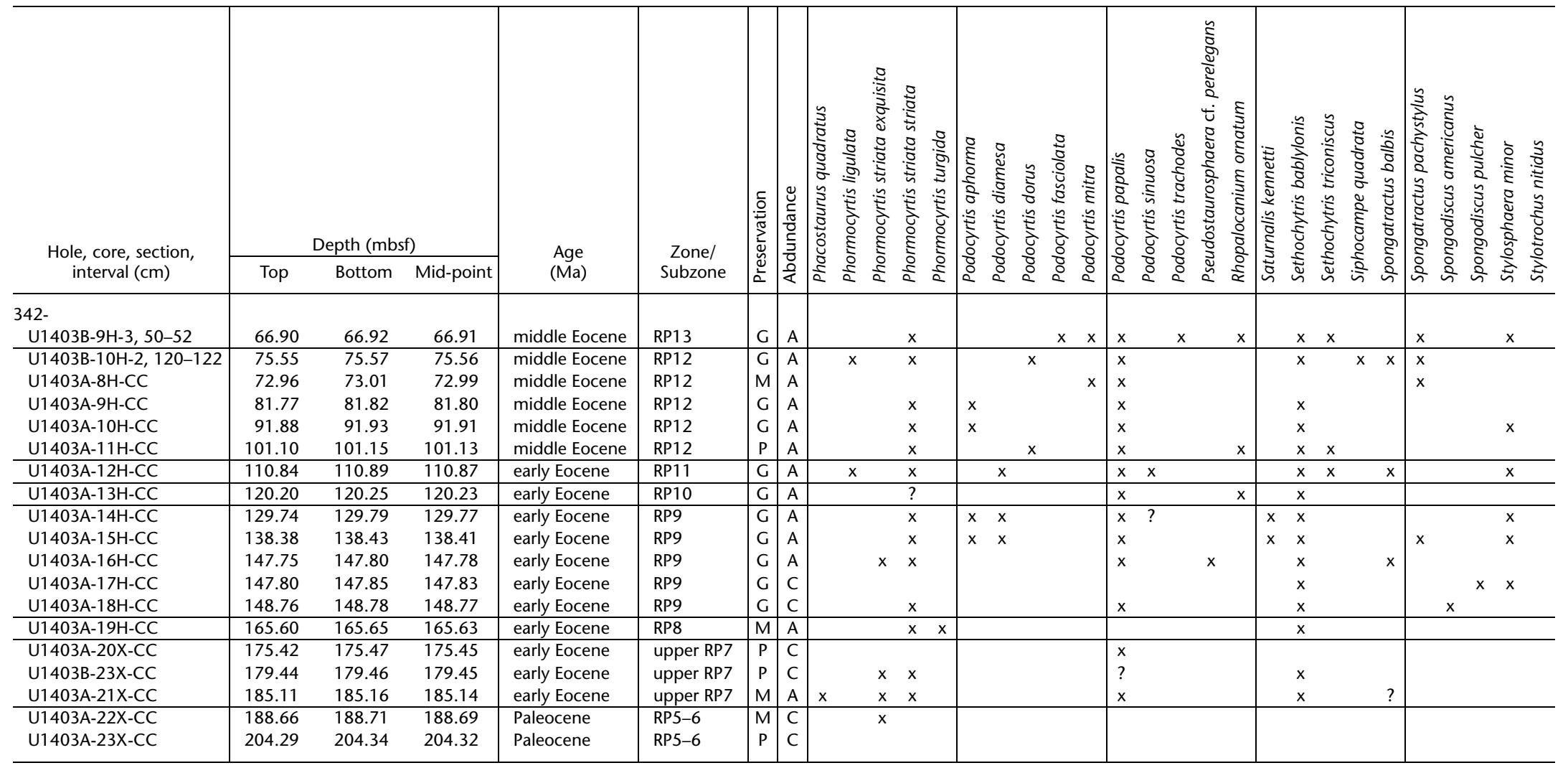




\begin{tabular}{|c|c|c|c|c|c|c|c|c|c|c|c|c|c|c|c|c|c|c|c|c|}
\hline \multirow{2}{*}{$\begin{array}{l}\text { Hole, core, section, } \\
\text { interval }(\mathrm{cm})\end{array}$} & \multicolumn{3}{|c|}{ Depth (mbsf) } & \multirow{2}{*}{$\begin{array}{l}\text { Age } \\
(\mathrm{Ma})\end{array}$} & \multirow{2}{*}{$\begin{array}{l}\text { Zone/ } \\
\text { Subzone }\end{array}$} & \multirow{2}{*}{ 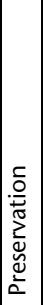 } & & \multirow{2}{*}{\multicolumn{2}{|c|}{ 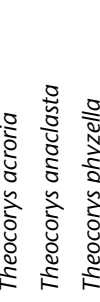 }} & \multirow[t]{2}{*}{ 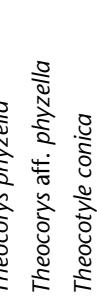 } & \multirow{2}{*}{\multicolumn{3}{|c|}{ 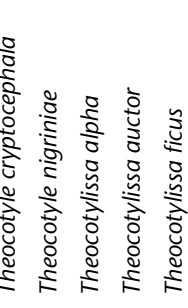 }} & \multirow[t]{2}{*}{ 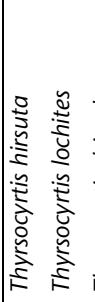 } & \multirow{2}{*}{\multicolumn{2}{|c|}{ 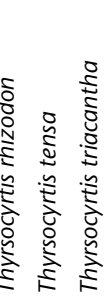 }} & \multirow[t]{2}{*}{ 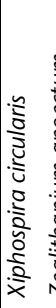 } & \multirow{2}{*}{\multicolumn{2}{|c|}{ 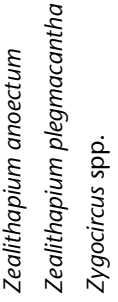 }} & \multirow{2}{*}{ 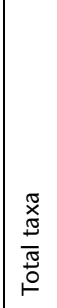 } \\
\hline & Top & Bottom & Mid-point & & & & \multicolumn{2}{|c|}{ 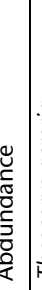 } & & & & & & & & & & & & \\
\hline \multicolumn{21}{|l|}{$342-$} \\
\hline U1403B-9H-3, 50-52 & 66.90 & 66.92 & 66.91 & middle Eocene & RP13 & $\mathrm{G}$ & A & & & & & & $\mathrm{x}$ & & $x$ & $x \quad x$ & & $x$ & $\mathrm{x}$ & 36 \\
\hline U1403B-10H-2, 120-122 & 75.55 & 75.57 & 75.56 & middle Eocene & RP12 & $\mathrm{G}$ & A & & & & & & $\mathrm{x}$ & $x$ & $\mathrm{x}$ & $x \quad x$ & $x \quad x$ & $x \quad x$ & $x$ & 38 \\
\hline U1403A-8H-CC & 72.96 & 73.01 & 72.99 & middle Eocene & RP12 & $M$ & A & & & & & $x$ & & $\mathrm{x}$ & $\mathrm{x}$ & $x \quad x$ & & & $\mathrm{x}$ & 14 \\
\hline U1403A-9H-CC & 81.77 & 81.82 & 81.80 & middle Eocene & RP12 & G & A & & & & & & $\mathrm{x}$ & & & & & & & 18 \\
\hline U1403A-10H-CC & 91.88 & 91.93 & 91.91 & middle Eocene & RP12 & G & A & & & $\mathrm{x}$ & $\mathrm{x}$ & $x \times$ & $x \quad x$ & $x$ & & & & & $\mathrm{x}$ & 27 \\
\hline U1403A-11H-CC & 101.10 & 101.15 & 101.13 & middle Eocene & RP12 & $\mathrm{P}$ & A & & & & $\mathrm{x}$ & & $\mathrm{x}$ & $x$ & & $\mathrm{x} \quad$ ? & & & $\mathrm{x}$ & 22 \\
\hline U1403A-12H-CC & 110.84 & 110.89 & 110.87 & early Eocene & RP11 & $\mathrm{G}$ & $\mathrm{A}$ & & & $\mathrm{x}$ & & & $\mathrm{x}$ & $\mathrm{x}$ & $\mathrm{x}$ & $\mathrm{x}$ & & $x$ & $\mathrm{x}$ & 35 \\
\hline U1403A-13H-CC & 120.20 & 120.25 & 120.23 & early Eocene & RP10 & $G$ & A & & $x$ & & $x$ & $x$ & $?$ & $\mathrm{x}$ & $x$ & $x$ & $x \quad x$ & $x$ & $x$ & 32 \\
\hline U1403A-14H-CC & 129.74 & 129.79 & 129.77 & early Eocene & RP9 & G & A & & $\mathrm{x}$ & $x$ & & $\mathrm{x}$ & $x$ & $\mathrm{x}$ & $\mathrm{x}$ & $\mathrm{x}$ & & $x$ & $x$ & 43 \\
\hline U1403A-15H-CC & 138.38 & 138.43 & 138.41 & early Eocene & RP9 & G & A & $x$ & $\mathrm{x}$ & $x$ & & $x$ & $x$ & $x$ & $?$ & $x$ & & & $x$ & 42 \\
\hline U1403A-16H-CC & 147.75 & 147.80 & 147.78 & early Eocene & RP9 & G & A & & & $x \quad x$ & & $x$ & & & & & & & & 30 \\
\hline U1403A-17H-CC & 147.80 & 147.85 & 147.83 & early Eocene & RP9 & G & C & & & & & & & $x$ & & & $x$ & & & 15 \\
\hline U1403A-18H-CC & 148.76 & 148.78 & 148.77 & early Eocene & RP9 & G & C & & & & & & $?$ & $x$ & & & & & & 16 \\
\hline U1403A-19H-CC & 165.60 & 165.65 & 165.63 & early Eocene & RP8 & $\mathrm{M}$ & A & & & & & & & $\mathrm{x}$ & & & & & & 9 \\
\hline U1403A-20X-CC & 175.42 & 175.47 & 175.45 & early Eocene & upper RP7 & $\mathrm{P}$ & C & & $\mathrm{x}$ & $x$ & & & & & & & & & & 5 \\
\hline U1403B-23X-CC & 179.44 & 179.46 & 179.45 & early Eocene & upper RP7 & $\mathrm{P}$ & C & & & $x \quad x$ & & & & & & & & & & \\
\hline U1403A-21X-CC & 185.11 & 185.16 & 185.14 & early Eocene & upper RP7 & M & A & & $\mathrm{x}$ & $x \quad x$ & & & $\mathrm{x}$ & & & & $x$ & & & 19 \\
\hline U1403A-22X-CC & 188.66 & 188.71 & 188.69 & Paleocene & RP5-6 & $\mathrm{M}$ & C & & & & & & & & & & & & & 7 \\
\hline U1403A-23X-CC & 204.29 & 204.34 & 204.32 & Paleocene & RP5-6 & $\mathrm{P}$ & & & & & & & & & & & & & & 5 \\
\hline
\end{tabular}

Table T7. Planktonic foraminifer datums, Site U1403.

\begin{tabular}{|c|c|c|c|c|c|c|c|c|c|}
\hline \multicolumn{2}{|c|}{ Hole, core, section, interval $(\mathrm{cm})$} & \multirow[b]{2}{*}{ Age } & \multirow[b]{2}{*}{ Subzone } & \multirow[b]{2}{*}{ Marker event } & \multirow{2}{*}{$\begin{array}{l}\text { Age } \\
\text { (Ma) }\end{array}$} & \multirow[b]{2}{*}{ Top } & \multicolumn{3}{|c|}{ Depth (mbsf) } \\
\hline Top & Bottom & & & & & & Bottom & Mid-point & \pm \\
\hline $342-$ & $342-$ & & & & & & & & \\
\hline U1403A-23X-7, 15-17 & U1403A-23X-CC & Paleocene & P3a & B Morozovella angulata & 62.29 & 203.65 & 204.34 & 204.00 & 0.34 \\
\hline U1403A-27X-3, 121-123 & U1403A-27X-4, 122-124 & Maastrichtian & & T Globotruncana bulloides & 68.82 & 228.41 & 229.94 & 229.18 & 0.77 \\
\hline U1403B-29X-CC & U1403A-27X-CC & & & T Globotruncana linneana & 70.90 & 233.19 & 234.68 & 233.94 & 0.75 \\
\hline U1403B-31X-1, 57-59 & U1403B-31X-2, 95-97 & & & B Contusotruncana contusa & 71.01 & 246.27 & 248.15 & 247.21 & 0.94 \\
\hline
\end{tabular}

$B=$ base, $T=$ top. 


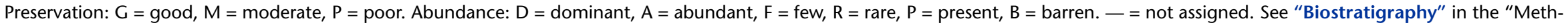
ods" chapter (Norris et al., 2014b) for preservation and abundance definitions. 

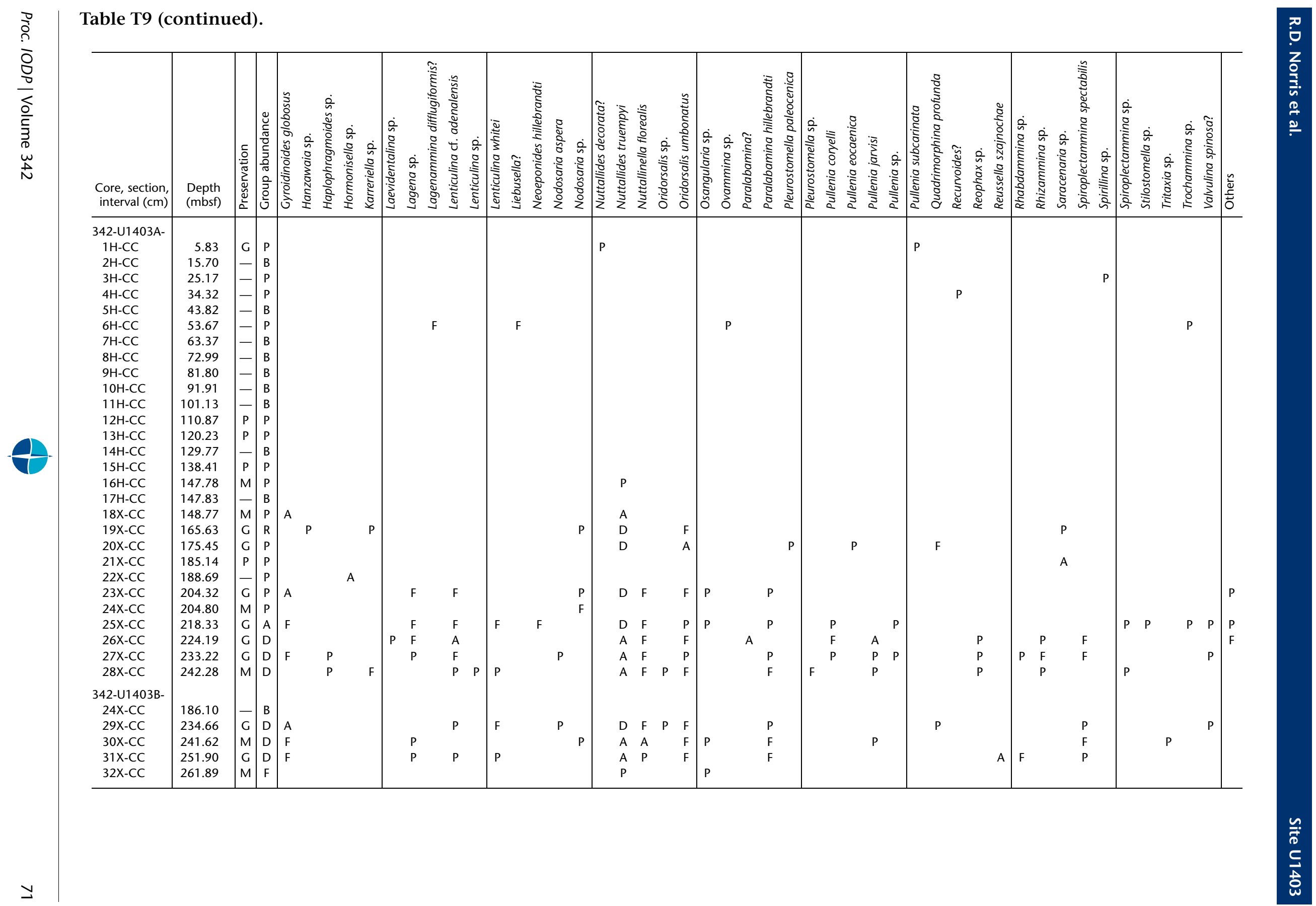
Table T10. Benthic foraminifer morphotype distribution, Site U1403.

\begin{tabular}{|c|c|c|c|c|c|c|c|c|}
\hline $\begin{array}{l}\text { Core, section, } \\
\text { interval }(\mathrm{cm})\end{array}$ & $\begin{array}{l}\text { Depth } \\
\text { (mbsf) }\end{array}$ & 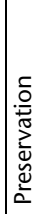 & 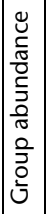 & & $\begin{array}{l}\frac{\pi}{\mathscr{T}} \\
\text { 은 } \\
\text { U. }\end{array}$ & 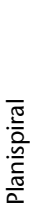 & 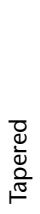 & 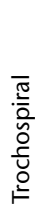 \\
\hline \multicolumn{9}{|l|}{$\begin{array}{l}342-\mathrm{U} 1403 \mathrm{~A}- \\
13 \mathrm{H}-7,25-27\end{array}$} \\
\hline $18 X-1,36-38$ & 148.37 & M & $\mathrm{P}$ & B & $P$ & B & $\mathrm{R}$ & $\mathrm{D}$ \\
\hline $20 X-1,78-80$ & 166.49 & G & $\mathrm{P}$ & B & B & $\mathrm{P}$ & $\mathrm{P}$ & D \\
\hline $20 X-2,10-12$ & 167.31 & $M$ & $\mathrm{P}$ & B & B & B & $P$ & $\mathrm{D}$ \\
\hline $20 x-3,56-58$ & 169.27 & G & $\mathrm{R}$ & $B$ & $B$ & B & $P$ & $\mathrm{D}$ \\
\hline $20 X-4,78-80$ & 170.99 & G & $\mathrm{F}$ & B & $P$ & B & B & $\mathrm{D}$ \\
\hline $20 X-5,86-88$ & 172.57 & G & $\mathrm{F}$ & B & B & B & B & $\mathrm{D}$ \\
\hline $20 X-6,75-77$ & 173.96 & M & $\mathrm{P}$ & $P$ & B & B & $P$ & $\mathrm{D}$ \\
\hline $20 X-7,49-51$ & 175.10 & $P$ & $\mathrm{P}$ & B & $P$ & B & B & D \\
\hline $23 X-4,120-122$ & 200.41 & G & $\mathrm{P}$ & $\mathrm{P}$ & $\mathrm{R}$ & $\mathrm{P}$ & $\mathrm{P}$ & D \\
\hline $23 X-5,65-67$ & 201.26 & G & $\mathrm{P}$ & P & $\mathrm{F}$ & B & $P$ & $\mathrm{D}$ \\
\hline $23 X-6,48-48$ & 202.59 & G & $\mathrm{P}$ & $P$ & $\mathrm{~F}$ & $\mathrm{P}$ & $P$ & D \\
\hline $23 X-7,15-17$ & 203.66 & G & $\mathrm{P}$ & B & $\mathrm{R}$ & $P$ & B & $\mathrm{D}$ \\
\hline $25 X-2,89-91$ & 212.10 & G & $\mathrm{P}$ & $\mathrm{P}$ & $\mathrm{R}$ & B & $P$ & D \\
\hline $25 X-3,72-74$ & 213.43 & $M$ & $\mathrm{P}$ & P & B & B & $P$ & $\mathrm{D}$ \\
\hline $25 X-4,50-52$ & 214.71 & G & $\mathrm{P}$ & $P$ & $P$ & B & $P$ & $\mathrm{D}$ \\
\hline $25 X-5,75-77$ & 216.46 & M & $\mathrm{P}$ & B & B & B & $\mathrm{R}$ & D \\
\hline $25 X-6,24-26$ & 217.45 & $P$ & $D$ & B & B & B & $P$ & $\mathrm{D}$ \\
\hline $26 \mathrm{X}-2,18-20$ & 216.19 & G & $\mathrm{F}$ & $\mathrm{F}$ & $\mathrm{R}$ & B & $P$ & D \\
\hline $26 \mathrm{X}-3,88-89$ & 218.39 & G & $\mathrm{P}$ & B & $\mathrm{F}$ & B & $P$ & $\mathrm{D}$ \\
\hline $26 X-4,20-21$ & 219.21 & $M$ & $\mathrm{P}$ & $P$ & $\mathrm{R}$ & $P$ & $P$ & D \\
\hline $26 X-5,3-4$ & 220.73 & $\mathrm{M}$ & $\mathrm{R}$ & $\mathrm{P}$ & $P$ & B & B & D \\
\hline $26 X-5,22-24$ & 220.54 & G & $\mathrm{F}$ & P & $\mathrm{R}$ & B & B & $\mathrm{D}$ \\
\hline $26 X-7,33-34$ & 223.60 & $M$ & $\mathrm{R}$ & $P$ & $P$ & B & B & $\mathrm{D}$ \\
\hline $27 X-1,96-98$ & 225.17 & G & D & $\mathrm{F}$ & $P$ & $P$ & $\mathrm{~F}$ & $\mathrm{D}$ \\
\hline $27 X-2,84-85$ & 226.55 & $M$ & $\mathrm{R}$ & B & $B$ & B & B & D \\
\hline $27 X-3,121-123$ & 228.42 & $M$ & $\mathrm{D}$ & $\mathrm{R}$ & $\mathrm{P}$ & $P$ & $\mathrm{~F}$ & $\mathrm{D}$ \\
\hline $27 X-4,122-124$ & 229.93 & G & D & P & B & $B$ & $\mathrm{R}$ & $\mathrm{F}$ \\
\hline $27 X-5,104-106$ & 231.25 & $\mathrm{M}$ & D & $\mathrm{P}$ & $P$ & B & B & D \\
\hline $27 X-6,102-104$ & 232.73 & G & D & $\mathrm{P}$ & $P$ & B & $\mathrm{R}$ & D \\
\hline 28X-1, 89-91 & 234.80 & G & D & $\mathrm{P}$ & $\mathrm{P}$ & $\mathrm{P}$ & $\mathrm{R}$ & D \\
\hline $28 \mathrm{X}-2,108-110$ & 236.49 & G & $\mathrm{D}$ & $\mathrm{P}$ & $P$ & $P$ & $\mathrm{R}$ & $\mathrm{D}$ \\
\hline $28 X-3,106-108$ & 237.97 & G & D & $\mathrm{R}$ & $\mathrm{P}$ & $\mathrm{P}$ & $\mathrm{R}$ & $\mathrm{D}$ \\
\hline $28 X-4,72-74$ & 239.13 & $M$ & D & $P$ & B & $P$ & $P$ & $\mathrm{D}$ \\
\hline $28 X-5,125-127$ & 241.16 & M & D & B & B & $P$ & $\mathrm{R}$ & $\mathrm{D}$ \\
\hline $28 X-6,34-36$ & 241.75 & $M$ & $D$ & $P$ & $P$ & $\mathrm{P}$ & $\mathrm{R}$ & $\mathrm{D}$ \\
\hline \multicolumn{9}{|l|}{ 342-U1403B- } \\
\hline $19 \mathrm{H}-3,84-86$ & 154.25 & G & $\mathrm{R}$ & B & $\mathrm{R}$ & B & $P$ & D \\
\hline $19 \mathrm{H}-4,32-34$ & 154.66 & G & $\mathrm{R}$ & B & $P$ & B & $P$ & $\mathrm{D}$ \\
\hline $29 X-4,25-27$ & 231.06 & G & $\mathrm{D}$ & $P$ & B & $\mathrm{R}$ & $P$ & $\mathrm{D}$ \\
\hline $30 X-1,72-74$ & 236.73 & G & $\mathrm{D}$ & $\mathrm{F}$ & $\mathrm{B}$ & B & $\mathrm{F}$ & $\mathrm{D}$ \\
\hline $30 X-2,61-63$ & 238.12 & G & D & $\mathrm{R}$ & $\mathrm{R}$ & $\mathrm{R}$ & $\mathrm{R}$ & $\mathrm{D}$ \\
\hline $30 X-3,43-45$ & 239.44 & G & D & P & $P$ & $P$ & $\mathrm{R}$ & D \\
\hline $30 X-4,29-31$ & 240.80 & G & D & $\mathrm{F}$ & $\mathrm{R}$ & B & $\mathrm{R}$ & D \\
\hline $31 X-1,57-59$ & 246.28 & G & D & $\mathrm{F}$ & B & $\mathrm{P}$ & $P$ & $\mathrm{D}$ \\
\hline $31 X-2,95-97$ & 248.16 & $M$ & $\mathrm{D}$ & P & $B$ & B & B & D \\
\hline $31 X-3,95-97$ & 249.66 & G & $\mathrm{D}$ & $\mathrm{F}$ & B & B & $\mathrm{F}$ & $\mathrm{D}$ \\
\hline $31 X-4,89-91$ & 251.10 & G & D & $\mathrm{R}$ & B & B & $P$ & $\mathrm{D}$ \\
\hline $32 X-1,66-68$ & 256.07 & - & B & & & & & \\
\hline $32 X-2,77-78$ & 257.68 & G & D & $\mathrm{R}$ & B & $\mathrm{P}$ & $\mathrm{R}$ & $\mathrm{D}$ \\
\hline $32 X-3,119-120$ & 259.60 & G & D & B & B & B & B & D \\
\hline $32 X-4,86-87$ & 260.77 & $M$ & D & $\mathrm{P}$ & $\mathrm{P}$ & B & $\mathrm{R}$ & D \\
\hline $32 X-5,22-24$ & 261.33 & G & D & $\mathrm{P}$ & $P$ & B & $P$ & $\mathrm{D}$ \\
\hline
\end{tabular}

Preservation: $\mathrm{G}=$ good, $\mathrm{M}=$ moderate, $\mathrm{P}=$ poor. Abundance: $\mathrm{D}=$ dominant, $\mathrm{A}=$ abundant, $\mathrm{F}=\mathrm{few}, \mathrm{R}=$ rare, $\mathrm{P}=$ present, $\mathrm{B}=$ barren. $-\mathrm{f}=$ not assigned. 
Table T11. Core orientation data, Site U1403.

\begin{tabular}{|c|c|c|c|}
\hline \multicolumn{2}{|c|}{ Hole U1403A } & \multicolumn{2}{|c|}{ Hole U1403B } \\
\hline Core & $\operatorname{MTF}\left({ }^{\circ}\right)$ & Core & $\operatorname{MTF}\left({ }^{\circ}\right)$ \\
\hline \multicolumn{2}{|c|}{ 342-U1403A- } & \multicolumn{2}{|c|}{ 342-U1403B- } \\
\hline $1 \mathrm{H}$ & 152 & $1 \mathrm{H}$ & 200 \\
\hline $2 \mathrm{H}$ & 303 & $2 \mathrm{H}$ & 41 \\
\hline $3 \mathrm{H}$ & 90 & $3 \mathrm{H}$ & 250 \\
\hline $4 \mathrm{H}$ & 233 & $4 \mathrm{H}$ & 328 \\
\hline $5 \mathrm{H}$ & 38 & $5 \mathrm{H}$ & 267 \\
\hline $6 \mathrm{H}$ & 152 & $6 \mathrm{H}$ & 190 \\
\hline $7 \mathrm{H}$ & 35 & $7 \mathrm{H}$ & 157 \\
\hline $8 \mathrm{H}$ & 267 & $8 \mathrm{H}$ & 142 \\
\hline $9 \mathrm{H}$ & 150 & $9 \mathrm{H}$ & 205 \\
\hline $10 \mathrm{H}$ & 249 & & \\
\hline $11 \mathrm{H}$ & 99 & & \\
\hline $12 \mathrm{H}$ & 118 & & \\
\hline $13 \mathrm{H}$ & 219 & & \\
\hline $14 \mathrm{H}$ & 164 & & \\
\hline $15 \mathrm{H}$ & 0 & & \\
\hline $16 \mathrm{H}$ & 276 & & \\
\hline
\end{tabular}

MTF = magnetic tool face orientation from geomagnetic north . 
Table T12. Summary of AF demagnetization results for discrete samples, Hole U1403A. (Continued on next page.)

\begin{tabular}{|c|c|c|c|c|c|c|}
\hline $\begin{array}{l}\text { Core, section, } \\
\text { interval }(\mathrm{cm})\end{array}$ & $\begin{array}{l}\text { Depth } \\
\text { (mbsf) }\end{array}$ & $\begin{array}{c}\text { Declination } \\
20 \mathrm{mT} \text { or PCA } \\
\left({ }^{\circ}\right)\end{array}$ & $\begin{array}{c}\text { Inclination } \\
20 \mathrm{mT}^{\circ} \text { or PCA } \\
\left({ }^{\circ}\right)\end{array}$ & $\begin{array}{l}\text { PCA } \\
\text { MAD } \\
\left({ }^{\circ}\right)\end{array}$ & $\begin{array}{l}\text { PCA } \\
\text { range } \\
(\mathrm{mT})\end{array}$ & $\begin{array}{l}\mathrm{NRM} \\
20 \mathrm{mT} \\
(\mathrm{A} / \mathrm{m})\end{array}$ \\
\hline \multicolumn{7}{|l|}{ 342-U1403A- } \\
\hline $1 \mathrm{H}-1 \mathrm{~W}, 30-32$ & 0.31 & 237.0 & -51.2 & & & $2.95 \mathrm{E}-02$ \\
\hline $1 \mathrm{H}-2 \mathrm{~W}, 75-77$ & 2.26 & 286.1 & 65.8 & & & 4.56E-03 \\
\hline $1 \mathrm{H}-3 \mathrm{~W}, 75-77$ & 3.76 & 41.6 & 77.0 & 4.1 & $20-80$ & $6.32 \mathrm{E}-03$ \\
\hline $1 \mathrm{H}-4 \mathrm{~W}, 54-56$ & 5.05 & 324.9 & 83.3 & & & $4.83 \mathrm{E}-03$ \\
\hline $2 \mathrm{H}-1 \mathrm{~W}, 75-77$ & 6.56 & 344.2 & 77.3 & & & $8.26 \mathrm{E}-03$ \\
\hline $2 \mathrm{H}-2 \mathrm{~W}, 75-77$ & 8.06 & 327.6 & 75.3 & & & $7.04 \mathrm{E}-03$ \\
\hline $2 \mathrm{H}-3 \mathrm{~W}, 75-77$ & 9.56 & 324.3 & 75.9 & 3.2 & $20-80$ & $5.72 \mathrm{E}-03$ \\
\hline $2 \mathrm{H}-4 \mathrm{~W}, 75-77$ & 11.06 & 278.0 & 21.7 & & & $1.54 \mathrm{E}-03$ \\
\hline $2 \mathrm{H}-5 \mathrm{~W}, 75-77$ & 12.56 & 284.8 & 62.0 & & & $2.73 \mathrm{E}-03$ \\
\hline $2 \mathrm{H}-6 \mathrm{~W}, 75-77$ & 14.06 & 271.9 & 53.9 & & & $1.99 \mathrm{E}-03$ \\
\hline $2 \mathrm{H}-7 \mathrm{~W}, 35-37$ & 15.16 & 330.7 & 72.0 & & & 5.07E-03 \\
\hline $3 \mathrm{H}-1 \mathrm{~W}, 85-87$ & 16.16 & 16.0 & 61.9 & & & $2.23 \mathrm{E}-04$ \\
\hline $3 \mathrm{H}-2 \mathrm{~W}, 75-77$ & 17.56 & 41.6 & 61.8 & & & $5.06 \mathrm{E}-05$ \\
\hline $3 \mathrm{H}-3 \mathrm{~W}, 75-77$ & 19.06 & 215.2 & -15.9 & & & 5.43E-05 \\
\hline $3 \mathrm{H}-4 \mathrm{~W}, 67-69$ & 20.48 & 14.9 & 63.6 & & & $4.98 \mathrm{E}-03$ \\
\hline $3 \mathrm{H}-5 \mathrm{~W}, 72-74$ & 22.03 & 166.7 & -18.3 & & & $1.80 \mathrm{E}-03$ \\
\hline $3 \mathrm{H}-6 \mathrm{~W}, 72-74$ & 23.53 & 0.6 & 58.3 & & & $1.11 \mathrm{E}-02$ \\
\hline $3 \mathrm{H}-7 \mathrm{~W}, 31-33$ & 24.62 & 12.7 & 63.1 & & & $7.36 \mathrm{E}-04$ \\
\hline $4 \mathrm{H}-1 \mathrm{~W}, 75-77$ & 25.56 & 356.4 & 49.6 & & & 8.64E-05 \\
\hline $4 \mathrm{H}-2 \mathrm{~W}, 75-77$ & 27.06 & 210.7 & 16.0 & & & $2.61 \mathrm{E}-05$ \\
\hline $4 \mathrm{H}-3 \mathrm{~W}, 75-77$ & 28.56 & 202.0 & -55.4 & & & $3.15 \mathrm{E}-05$ \\
\hline $4 \mathrm{H}-4 \mathrm{~W}, 75-77$ & 30.06 & 198.9 & -30.9 & & & 7.63E-05 \\
\hline $4 \mathrm{H}-5 \mathrm{~W}, 75-77$ & 31.56 & 182.5 & -47.2 & & & $1.05 \mathrm{E}-04$ \\
\hline $4 \mathrm{H}-6 \mathrm{~W}, 55-57$ & 32.86 & 173.5 & -25.2 & & & $6.98 \mathrm{E}-05$ \\
\hline $4 \mathrm{H}-7 \mathrm{~W}, 28-30$ & 33.79 & 341.4 & 34.8 & & & $8.21 \mathrm{E}-05$ \\
\hline $5 \mathrm{H}-1 \mathrm{~W}, 75-77$ & 35.06 & 147.8 & -2.7 & & & $1.48 \mathrm{E}-05$ \\
\hline $5 \mathrm{H}-2 \mathrm{~W}, 75-77$ & 36.56 & 50.8 & 45.7 & & & $1.11 \mathrm{E}-04$ \\
\hline $5 \mathrm{H}-3 \mathrm{~W}, 75-77$ & 38.06 & 45.4 & 68.5 & & & 1.47E-03 \\
\hline $5 \mathrm{H}-4 \mathrm{~W}, 75-77$ & 39.56 & 19.2 & 59.5 & & & $4.35 \mathrm{E}-03$ \\
\hline $5 \mathrm{H}-5 \mathrm{~W}, 75-77$ & 41.06 & 186.9 & -29.1 & & & $3.06 \mathrm{E}-03$ \\
\hline $5 \mathrm{H}-6 \mathrm{~W}, 75-77$ & 42.56 & 26.4 & 49.4 & & & $3.36 \mathrm{E}-03$ \\
\hline $5 \mathrm{H}-7 \mathrm{~W}, 15-17$ & 43.26 & 14.0 & 46.3 & & & $3.20 \mathrm{E}-03$ \\
\hline $6 \mathrm{H}-1 \mathrm{~W}, 75-77$ & 44.56 & 18.8 & 43.0 & & & 7.17E-03 \\
\hline $6 \mathrm{H}-2 \mathrm{~W}, 65-67$ & 45.96 & 22.7 & 63.6 & & & $1.62 \mathrm{E}-03$ \\
\hline $6 \mathrm{H}-3 \mathrm{~W}, 75-77$ & 47.58 & 22.0 & 39.3 & 10.9 & $20-80$ & $2.72 \mathrm{E}-03$ \\
\hline $6 \mathrm{H}-4 \mathrm{~W}, 75-77$ & 49.10 & 24.0 & 34.2 & & & 3.67E-03 \\
\hline $6 \mathrm{H}-5 \mathrm{~W}, 75-77$ & 50.62 & 34.2 & 39.8 & & & $2.46 \mathrm{E}-03$ \\
\hline $6 \mathrm{H}-6 \mathrm{~W}, 75-77$ & 52.14 & 21.9 & 28.8 & & & $3.78 \mathrm{E}-03$ \\
\hline $6 \mathrm{H}-7 \mathrm{~W}, 25-27$ & 53.14 & 12.7 & 18.4 & & & $4.45 \mathrm{E}-03$ \\
\hline $7 \mathrm{H}-1 \mathrm{~W}, 75-77$ & 54.06 & 203.2 & -25.5 & & & $3.20 \mathrm{E}-03$ \\
\hline $7 \mathrm{H}-2 \mathrm{~W}, 75-77$ & 55.56 & 212.3 & -32.8 & & & $1.22 \mathrm{E}-03$ \\
\hline 7H-3W, 90-92 & 57.21 & 221.8 & -44.8 & 21.6 & $20-80$ & $2.76 \mathrm{E}-03$ \\
\hline $7 \mathrm{H}-4 \mathrm{~W}, 75-77$ & 58.56 & 208.6 & -21.8 & & & $2.88 \mathrm{E}-03$ \\
\hline 7H-5W, 75-77 & 60.06 & 35.7 & 36.6 & & & $1.60 \mathrm{E}-03$ \\
\hline $7 \mathrm{H}-6 \mathrm{~W}, 75-77$ & 61.56 & 235.1 & -7.8 & & & 2.79E-03 \\
\hline $7 \mathrm{H}-7 \mathrm{~W}, 25-27$ & 62.56 & 227.4 & -6.2 & & & $3.34 \mathrm{E}-03$ \\
\hline $8 \mathrm{H}-1 \mathrm{~W}, 75-77$ & 63.56 & 68.4 & 3.0 & & & $2.29 \mathrm{E}-03$ \\
\hline $8 \mathrm{H}-2 \mathrm{~W}, 75-77$ & 65.06 & 227.6 & 28.0 & & & $3.84 \mathrm{E}-03$ \\
\hline $8 \mathrm{H}-3 \mathrm{~W}, 75-77$ & 66.56 & 232.4 & 23.6 & 22.6 & $20-80$ & $4.18 \mathrm{E}-03$ \\
\hline $8 \mathrm{H}-4 \mathrm{~W}, 75-77$ & 68.06 & 236.1 & 32.1 & & & $3.12 \mathrm{E}-03$ \\
\hline $8 \mathrm{H}-5 \mathrm{~W}, 75-77$ & 69.59 & 238.3 & 27.8 & & & $2.51 \mathrm{E}-03$ \\
\hline $8 \mathrm{H}-6 \mathrm{~W}, 75-77$ & 71.09 & 222.3 & 21.6 & & & 4.74E-03 \\
\hline $8 \mathrm{H}-7 \mathrm{~W}, 37-39$ & 72.21 & 226.1 & 17.9 & & & $4.83 \mathrm{E}-03$ \\
\hline $9 \mathrm{H}-1 \mathrm{~W}, 75-77$ & 73.06 & 358.0 & 18.7 & & & $2.50 \mathrm{E}-03$ \\
\hline $9 \mathrm{H}-2 \mathrm{~W}, 75-77$ & 74.56 & 159.3 & -3.8 & & & $4.52 \mathrm{E}-03$ \\
\hline $9 \mathrm{H}-3 \mathrm{~W}, 75-77$ & 76.06 & 157.5 & -15.5 & 9.4 & $20-80$ & $5.96 \mathrm{E}-03$ \\
\hline $9 \mathrm{H}-4 \mathrm{~W}, 75-77$ & 77.53 & 155.5 & -2.5 & & & $4.75 \mathrm{E}-03$ \\
\hline $9 \mathrm{H}-5 \mathrm{~W}, 75-77$ & 79.00 & 146.0 & -0.9 & & & $3.82 \mathrm{E}-03$ \\
\hline $9 \mathrm{H}-6 \mathrm{~W}, 75-77$ & 80.46 & 153.3 & 5.4 & & & $3.52 \mathrm{E}-03$ \\
\hline $9 \mathrm{H}-7 \mathrm{~W}, 28-30$ & 81.29 & 138.1 & 23.0 & & & $2.64 \mathrm{E}-03$ \\
\hline $10 \mathrm{H}-1 \mathrm{~W}, 75-77$ & 82.56 & 183.1 & -9.5 & & & $3.94 \mathrm{E}-03$ \\
\hline $10 \mathrm{H}-2 \mathrm{~W}, 75-77$ & 84.07 & 184.0 & -5.0 & & & $1.47 \mathrm{E}-03$ \\
\hline $10 \mathrm{H}-3 \mathrm{~W}, 75-77$ & 85.58 & 192.5 & 0.4 & & & $2.95 \mathrm{E}-03$ \\
\hline $10 \mathrm{H}-4 \mathrm{~W}, 75-77$ & 87.04 & 190.8 & -13.6 & & & 4.77E-03 \\
\hline $10 \mathrm{H}-5 \mathrm{~W}, 75-77$ & 88.51 & 187.4 & -8.2 & & & $2.80 \mathrm{E}-03$ \\
\hline
\end{tabular}


Table T12 (continued).

\begin{tabular}{|c|c|c|c|c|c|c|}
\hline $\begin{array}{l}\text { Core, section, } \\
\text { interval }(\mathrm{cm})\end{array}$ & $\begin{array}{l}\text { Depth } \\
\text { (mbsf) }\end{array}$ & $\begin{array}{c}\text { Declination } \\
20 \mathrm{mT} \text { or PCA } \\
\left({ }^{\circ}\right)\end{array}$ & $\begin{array}{c}\text { Inclination } \\
20 \mathrm{mT} \text { or PCA } \\
\left({ }^{\circ}\right)\end{array}$ & $\begin{array}{c}\text { PCA } \\
\text { MAD } \\
\left(^{\circ}\right)\end{array}$ & $\begin{array}{c}\text { PCA } \\
\text { range } \\
(\mathrm{mT})\end{array}$ & $\begin{array}{l}\text { NRM } \\
20 \mathrm{mT} \\
(\mathrm{A} / \mathrm{m})\end{array}$ \\
\hline $10 \mathrm{H}-6 \mathrm{~W}, 75-77$ & 89.97 & 181.8 & -7.0 & & & $1.10 \mathrm{E}-04$ \\
\hline $10 \mathrm{H}-7 \mathrm{~W}, 40-42$ & 91.12 & 199.2 & -3.8 & & & 1.87E-03 \\
\hline $11 \mathrm{H}-1 \mathrm{~W}, 75-77$ & 92.06 & 156.5 & -10.6 & & & $4.72 \mathrm{E}-03$ \\
\hline $11 \mathrm{H}-2 \mathrm{~W}, 75-77$ & 93.56 & 147.9 & -5.1 & & & $4.26 \mathrm{E}-03$ \\
\hline $11 \mathrm{H}-3 \mathrm{~W}, 68-70$ & 94.99 & 145.3 & -15.6 & 4.0 & $10-80$ & $2.43 \mathrm{E}-03$ \\
\hline $11 \mathrm{H}-4 \mathrm{~W}, 75-77$ & 96.56 & 141.7 & -4.0 & & & $3.71 \mathrm{E}-03$ \\
\hline $11 \mathrm{H}-5 \mathrm{~W}, 75-77$ & 98.06 & 124.1 & 0.9 & & & $4.06 \mathrm{E}-03$ \\
\hline $11 \mathrm{H}-6 \mathrm{~W}, 70-72$ & 99.51 & 135.5 & 2.4 & & & $3.81 \mathrm{E}-04$ \\
\hline $11 \mathrm{H}-7 \mathrm{~W}, 23-25$ & 100.54 & 148.9 & -10.8 & & & $2.79 \mathrm{E}-03$ \\
\hline $12 \mathrm{H}-1 \mathrm{~W}, 75-77$ & 101.56 & 182.5 & -17.4 & & & $1.26 \mathrm{E}-04$ \\
\hline $12 \mathrm{H}-2 \mathrm{~W}, 74-76$ & 103.05 & 188.4 & -25.3 & & & $2.18 \mathrm{E}-04$ \\
\hline $12 \mathrm{H}-3 \mathrm{~W}, 78-80$ & 104.59 & 162.8 & -20.6 & 14.7 & $20-80$ & 1.57E-04 \\
\hline $12 \mathrm{H}-4 \mathrm{~W}, 76-78$ & 106.08 & 179.2 & 1.6 & & & $1.78 \mathrm{E}-03$ \\
\hline $12 \mathrm{H}-5 \mathrm{~W}, 68-70$ & 107.50 & 172.8 & -19.4 & & & $1.92 \mathrm{E}-03$ \\
\hline $12 \mathrm{H}-6 \mathrm{~W}, 73-75$ & 109.06 & 163.6 & -15.3 & & & $9.12 \mathrm{E}-04$ \\
\hline $12 \mathrm{H}-7 \mathrm{~W}, 31-33$ & 110.14 & 30.3 & 12.6 & & & $1.85 \mathrm{E}-03$ \\
\hline $13 \mathrm{H}-1 \mathrm{~W}, 80-82$ & 111.11 & 357.6 & 46.7 & & & $2.03 \mathrm{E}-03$ \\
\hline $13 \mathrm{H}-2 \mathrm{~W}, 55-57$ & 112.36 & 344.1 & 24.3 & & & $2.14 \mathrm{E}-03$ \\
\hline $13 \mathrm{H}-3 \mathrm{~W}, 75-77$ & 114.03 & 347.2 & 32.3 & 8.7 & $20-80$ & 4.10E-04 \\
\hline $13 \mathrm{H}-4 \mathrm{~W}, 75-77$ & 115.50 & 352.2 & 29.4 & & & $2.83 \mathrm{E}-04$ \\
\hline $13 \mathrm{H}-5 \mathrm{~W}, 75-77$ & 116.97 & 333.3 & 7.0 & & & $6.53 \mathrm{E}-05$ \\
\hline $13 \mathrm{H}-6 \mathrm{~W}, 60-62$ & 118.29 & 341.1 & 31.5 & & & $5.58 \mathrm{E}-05$ \\
\hline $13 \mathrm{H}-7 \mathrm{~W}, 32-34$ & 119.47 & 357.7 & 33.3 & & & $4.28 \mathrm{E}-05$ \\
\hline $14 \mathrm{H}-1 \mathrm{~W}, 75-77$ & 120.56 & 352.7 & 24.9 & & & $1.21 \mathrm{E}-04$ \\
\hline $14 \mathrm{H}-2 \mathrm{~W}, 70-72$ & 122.03 & 343.9 & 20.9 & & & $8.71 \mathrm{E}-05$ \\
\hline $14 \mathrm{H}-3 \mathrm{~W}, 70-72$ & 123.50 & 332.2 & 59.9 & & & 1.47E-05 \\
\hline $14 \mathrm{H}-4 \mathrm{~W}, 69-71$ & 124.96 & 313.2 & 26.6 & & & $1.90 \mathrm{E}-05$ \\
\hline $14 \mathrm{H}-5 \mathrm{~W}, 70-72$ & 126.43 & 326.0 & 31.0 & & & $4.55 \mathrm{E}-05$ \\
\hline $14 \mathrm{H}-6 \mathrm{~W}, 65-67$ & 127.84 & 344.9 & 28.0 & & & $2.30 \mathrm{E}-04$ \\
\hline $14 \mathrm{H}-7 \mathrm{~W}, 44-46$ & 129.09 & 351.1 & 15.1 & & & $1.48 \mathrm{E}-04$ \\
\hline $15 \mathrm{H}-1 \mathrm{~W}, 74-76$ & 130.05 & -19.8 & 35.5 & & & $1.85 \mathrm{E}-03$ \\
\hline $15 \mathrm{H}-2 \mathrm{~W}, 74-76$ & 131.55 & 188.5 & -40.7 & & & $9.29 \mathrm{E}-04$ \\
\hline $15 \mathrm{H}-3 \mathrm{~W}, 64-66$ & 132.95 & 166.0 & -1.2 & & & 7.96E-04 \\
\hline $15 \mathrm{H}-4 \mathrm{~W}, 64-66$ & 134.45 & 168.3 & -51.8 & & & $1.53 \mathrm{E}-03$ \\
\hline $15 \mathrm{H}-5 \mathrm{~W}, 64-66$ & 135.95 & 206.2 & -38.5 & & & $1.93 \mathrm{E}-04$ \\
\hline $15 \mathrm{H}-6 \mathrm{~W}, 66-68$ & 137.47 & 177.2 & -52.6 & & & $1.29 \mathrm{E}-03$ \\
\hline $16 \mathrm{H}-1 \mathrm{~W}, 75-77$ & 139.56 & 14.3 & 47.3 & & & $1.41 \mathrm{E}-03$ \\
\hline $16 \mathrm{H}-2 \mathrm{~W}, 75-77$ & 141.01 & 211.5 & 5.0 & & & $1.54 \mathrm{E}-03$ \\
\hline $16 \mathrm{H}-3 \mathrm{~W}, 74-76$ & 142.45 & 273.5 & 67.8 & & & $4.24 \mathrm{E}-03$ \\
\hline $16 \mathrm{H}-4 \mathrm{~W}, 74-76$ & 143.90 & 301.9 & 63.5 & & & $3.72 \mathrm{E}-03$ \\
\hline $16 \mathrm{H}-5 \mathrm{~W}, 74-76$ & 145.35 & 74.6 & 32.8 & & & $3.54 \mathrm{E}-03$ \\
\hline $16 \mathrm{H}-6 \mathrm{~W}, 74-76$ & 146.80 & 302.6 & 57.0 & & & $3.09 \mathrm{E}-03$ \\
\hline $23 X-3 W, 24-26$ & 198.05 & 205.5 & -25.5 & & & $1.41 \mathrm{E}-03$ \\
\hline $23 X-6 W, 94-96$ & 203.05 & 244.4 & 32.1 & & & $2.41 \mathrm{E}-03$ \\
\hline $25 X-4 W, 63-65$ & 214.84 & 181.7 & 61.6 & 2.4 & $20-60$ & 1.57E-02 \\
\hline 25X-5W, 114-116 & 216.85 & 305.6 & 56.0 & 9.6 & $20-40$ & $5.46 \mathrm{E}-03$ \\
\hline $26 X-1 W, 50-52$ & 215.01 & -70.4 & 33.0 & & & $2.52 \mathrm{E}-03$ \\
\hline $26 X-1 W, 130-132$ & 215.81 & 237.9 & 70.6 & & & $6.45 \mathrm{E}-03$ \\
\hline $27 X-5 W, 31-33$ & 230.52 & -30.8 & -47.8 & & & 2.07E-03 \\
\hline $27 X-6 W, 120-122$ & 232.91 & -3.4 & 9.6 & & & $1.80 \mathrm{E}-03$ \\
\hline $28 X-5 W, 53-55$ & 240.44 & -54.2 & 69.7 & & & $1.71 \mathrm{E}-03$ \\
\hline $28 X-6 W, 45-47$ & 241.86 & 35.0 & 72.0 & & & 2.77E-03 \\
\hline
\end{tabular}

Declinations for Cores $1 \mathrm{H}-16 \mathrm{H}$ are corrected into geographical coordinates using the FlexIT orientation data. PCA = principal component analysis, $\mathrm{MAD}=$ maximum angular deviation, $\mathrm{NRM}=$ natural remanent magnetism . 
Table T13. Summary of AF demagnetization results for discrete samples, Hole U1403B.

\begin{tabular}{|c|c|c|c|c|c|c|}
\hline $\begin{array}{l}\text { Core, section, } \\
\text { interval }(\mathrm{cm})\end{array}$ & $\begin{array}{l}\text { Depth } \\
\text { (mbsf) }\end{array}$ & $\begin{array}{c}\text { Declination } \\
20 \mathrm{mT} \text { or PCA } \\
\left({ }^{\circ}\right)\end{array}$ & $\begin{array}{c}\text { Inclination } \\
20 \mathrm{mT} \text { or PCA } \\
\left(^{\circ}\right)\end{array}$ & $\begin{array}{l}\text { PCA } \\
\text { MAD } \\
\left({ }^{\circ}\right)\end{array}$ & $\begin{array}{l}\text { PCA } \\
\text { range } \\
(\mathrm{mT})\end{array}$ & $\begin{array}{l}\mathrm{NRM} \\
20 \mathrm{mT} \\
(\mathrm{A} / \mathrm{m})\end{array}$ \\
\hline \multicolumn{7}{|l|}{ 342-U1403B- } \\
\hline $19 \mathrm{H}-1 \mathrm{~W}, 74-76$ & 151.15 & 37.9 & -0.4 & & & $3.96 \mathrm{E}-03$ \\
\hline $19 \mathrm{H}-2 \mathrm{~W}, 101-103$ & 152.92 & 40.2 & -5.7 & & & $4.92 \mathrm{E}-03$ \\
\hline $19 \mathrm{H}-3 \mathrm{~W}, 48-50$ & 153.89 & 39.8 & -10.8 & & & $3.05 \mathrm{E}-03$ \\
\hline $19 \mathrm{H}-4 \mathrm{~W}, 47-49$ & 154.81 & -39.4 & 43.3 & & & $4.73 \mathrm{E}-04$ \\
\hline $20 \mathrm{H}-1 \mathrm{~W}, 65-67$ & 155.66 & 43.0 & -35.0 & & & $2.91 \mathrm{E}-03$ \\
\hline $20 \mathrm{H}-2 \mathrm{~W}, 74-76$ & 157.25 & 13.8 & -53.4 & & & $2.73 \mathrm{E}-03$ \\
\hline $20 \mathrm{H}-3 \mathrm{~W}, 60-62$ & 158.61 & 31.8 & -56.4 & & & $2.94 \mathrm{E}-03$ \\
\hline $20 \mathrm{H}-4 \mathrm{~W}, 70-72$ & 160.21 & -24.5 & -73.5 & & & $4.90 \mathrm{E}-03$ \\
\hline $20 \mathrm{H}-5 \mathrm{~W}, 62-64$ & 161.64 & 305.7 & -39.0 & 15.3 & $10-60$ & $4.71 \mathrm{E}-03$ \\
\hline $20 \mathrm{H}-6 \mathrm{~W}, 54-56$ & 163.08 & -24.8 & -77.7 & & & $4.34 \mathrm{E}-04$ \\
\hline $21 \mathrm{H}-1 \mathrm{~W}, 74-76$ & 164.75 & -14.8 & 46.8 & & & $1.06 \mathrm{E}-04$ \\
\hline $21 \mathrm{H}-2 \mathrm{~W}, 74-76$ & 166.25 & -27.6 & 52.5 & & & $2.46 \mathrm{E}-04$ \\
\hline $21 \mathrm{H}-3 \mathrm{~W}, 78-80$ & 167.79 & -19.3 & 66.7 & & & $6.45 \mathrm{E}-05$ \\
\hline $21 \mathrm{H}-4 \mathrm{~W}, 74-76$ & 169.25 & -26.9 & 48.4 & & & $5.34 \mathrm{E}-05$ \\
\hline $21 \mathrm{H}-5 \mathrm{~W}, 74-76$ & 170.75 & -20.9 & 34.7 & & & $8.09 \mathrm{E}-05$ \\
\hline $21 \mathrm{H}-6 \mathrm{~W}, 55-57$ & 172.06 & -3.0 & 41.4 & & & 7.39E-04 \\
\hline $21 \mathrm{H}-7 \mathrm{~W}, 24-26$ & 172.75 & -19.2 & 41.6 & & & $3.41 \mathrm{E}-03$ \\
\hline $22 \mathrm{H}-1 \mathrm{~W}, 70-72$ & 173.71 & -46.8 & 251.3 & & & $9.39 \mathrm{E}-04$ \\
\hline $22 \mathrm{H}-2 \mathrm{~W}, 70-72$ & 175.21 & -28.7 & -77.8 & & & $2.54 \mathrm{E}-03$ \\
\hline $23 X-1 W, 125-127$ & 177.16 & 30.5 & -65.5 & & & $4.20 \mathrm{E}-03$ \\
\hline $23 \mathrm{X}-2 \mathrm{~W}, 70-72$ & 178.11 & 7.1 & -38.0 & & & $6.28 \mathrm{E}-03$ \\
\hline $23 X-3 W, 30-32$ & 178.81 & 37.9 & -39.0 & & & $5.92 \mathrm{E}-03$ \\
\hline $24 \mathrm{X}-1 \mathrm{~W}, 99-101$ & 185.50 & 11.4 & -12.1 & & & $6.30 \mathrm{E}-04$ \\
\hline $25 \mathrm{X}-2 \mathrm{~W}, 106-108$ & 190.07 & 71.8 & 232.2 & & & $1.13 \mathrm{E}-02$ \\
\hline $25 X-6 W, 90-92$ & 195.91 & -0.4 & -80.2 & & & $3.18 \mathrm{E}-03$ \\
\hline $28 X-3 W, 70-72$ & 220.31 & 45.9 & -73.7 & & & $3.23 \mathrm{E}-03$ \\
\hline $28 X-3 W, 130-132$ & 220.91 & -0.1 & -57.5 & & & $2.76 \mathrm{E}-03$ \\
\hline $29 X-1 W, 62-64$ & 226.93 & 23.3 & 2.2 & & & $4.53 \mathrm{E}-03$ \\
\hline $29 X-1 W, 134-136$ & 227.65 & -26.9 & -2.9 & & & $2.85 \mathrm{E}-03$ \\
\hline $29 X-2 W, 90-92$ & 228.71 & 14.1 & -18.2 & & & $3.60 \mathrm{E}-03$ \\
\hline $29 X-3 W, 63-65$ & 229.94 & 36.3 & -42.5 & & & $2.99 \mathrm{E}-03$ \\
\hline 29X-4W, 101-103 & 231.82 & 6.7 & 1.6 & & & $2.84 \mathrm{E}-03$ \\
\hline $29 X-5 W, 25-27$ & 232.56 & -2.1 & 30.6 & & & $2.75 \mathrm{E}-03$ \\
\hline $29 X-5 W, 75-77$ & 233.06 & 24.7 & -24.1 & & & $8.79 \mathrm{E}-03$ \\
\hline $30 X-1 W, 72-74$ & 236.73 & 24.6 & -42.7 & & & $5.70 \mathrm{E}-03$ \\
\hline $30 \mathrm{X}-2 \mathrm{~W}, 61-63$ & 238.12 & 21.5 & -26.9 & & & $2.37 \mathrm{E}-03$ \\
\hline $30 X-3 W, 44-46$ & 239.45 & 63.9 & 30.7 & & & $4.99 \mathrm{E}-03$ \\
\hline $30 X-4 W, 30-32$ & 240.81 & 20.1 & -9.1 & & & $5.30 \mathrm{E}-03$ \\
\hline $31 X-1 W, 78-80$ & 246.49 & -20.8 & -20.2 & & & 8.37E-03 \\
\hline $31 X-2 W, 60-62$ & 247.81 & 32.1 & -18.9 & & & $6.96 \mathrm{E}-03$ \\
\hline $31 X-3 W, 74-76$ & 249.45 & 68.6 & -73.1 & & & $1.80 \mathrm{E}-02$ \\
\hline $31 X-4 W, 64-66$ & 250.85 & 31.8 & -2.1 & & & $1.95 \mathrm{E}-02$ \\
\hline $32 \mathrm{X}-1 \mathrm{~W}, 75-77$ & 256.16 & 37.5 & -32.0 & & & $8.03 \mathrm{E}-03$ \\
\hline $32 \mathrm{X}-2 \mathrm{~W}, 90-92$ & 257.81 & 41.3 & -33.5 & & & $4.21 \mathrm{E}-03$ \\
\hline $32 X-3 W, 43-45$ & 258.84 & 15.7 & 25.0 & & & $3.67 \mathrm{E}-03$ \\
\hline $32 X-4 W, 58-60$ & 260.49 & 59.6 & 267.3 & & & $4.21 \mathrm{E}-03$ \\
\hline $32 X-5 W, 16-18$ & 261.27 & 38.2 & -22.9 & & & $6.89 \mathrm{E}-03$ \\
\hline
\end{tabular}

Declinations are not corrected into geographical coordinates. $\mathrm{PCA}=$ principal component analysis, $\mathrm{MAD}=$ maximum angle of deviation, $\mathrm{NRM}=$ natural remanent magnetism. 
Table T14. Magnetostratigraphic tie points, Site U1403.

\begin{tabular}{|c|c|c|c|c|c|c|c|c|c|c|c|}
\hline \multirow[b]{3}{*}{ Chron boundary } & \multirow[b]{3}{*}{$\begin{array}{l}\text { Age } \\
(\mathrm{Ma})\end{array}$} & \multicolumn{5}{|c|}{ Hole U1403A } & \multicolumn{5}{|c|}{ Hole U1403B } \\
\hline & & \multicolumn{2}{|l|}{ Top } & \multicolumn{2}{|c|}{ Bottom } & \multirow[b]{2}{*}{$\begin{array}{c}\text { Mid-point } \\
\text { (mbsf) }\end{array}$} & \multicolumn{2}{|l|}{ Top } & \multicolumn{2}{|c|}{ Bottom } & \multirow[b]{2}{*}{$\begin{array}{c}\text { Mid-poin } \\
(\mathrm{mbsf})\end{array}$} \\
\hline & & $\begin{array}{l}\text { Core, section, } \\
\text { interval (cm) }\end{array}$ & $\begin{array}{l}\text { Depth } \\
\text { (mbsf) }\end{array}$ & $\begin{array}{l}\text { Core, section, } \\
\text { interval }(\mathrm{cm})\end{array}$ & $\begin{array}{l}\text { Depth } \\
\text { (mbsf) }\end{array}$ & & $\begin{array}{l}\text { Core, section, } \\
\text { interval }(\mathrm{cm})\end{array}$ & $\begin{array}{l}\text { Depth } \\
\text { (mbsf) }\end{array}$ & $\begin{array}{l}\text { Core, section, } \\
\text { interval }(\mathrm{cm})\end{array}$ & $\begin{array}{l}\text { Depth } \\
\text { (mbsf) }\end{array}$ & \\
\hline $\mathrm{C} 16 n .1 \mathrm{n} / \mathrm{C} 16 \mathrm{n} .1 \mathrm{r}$ & 35.892 & $\begin{array}{l}\text { 342-U1403A- } \\
\mathrm{NI}\end{array}$ & $\mathrm{NI}$ & $\begin{array}{l}\text { 342-U1403A- } \\
\mathrm{NI}\end{array}$ & $\mathrm{NI}$ & $\mathrm{NI}$ & $\begin{array}{r}342-U 1403 B- \\
6 \mathrm{H}-5 \mathrm{~A}, 95.0\end{array}$ & 41.85 & $\begin{array}{r}342-\mathrm{U} 1403 \mathrm{~B}- \\
6 \mathrm{H}-5 \mathrm{~A}, 97.5\end{array}$ & 41.875 & 41.86 \\
\hline $\mathrm{C} 16 n .1 \mathrm{r} / \mathrm{C} 16 \mathrm{n} .2 \mathrm{n}$ & 36.051 & $6 \mathrm{H}-2 \mathrm{~A}, 117.5$ & 46.48 & $6 \mathrm{H}-2 \mathrm{~A}, 135.0$ & 46.65 & 46.57 & $6 \mathrm{H}-5 \mathrm{~A}, 110.0$ & 42.00 & $6 \mathrm{H}-5 \mathrm{~A}, 112.5$ & 42.03 & 42.02 \\
\hline $\mathrm{C} 16 n \cdot 2 n / C 16 r$ & 36.700 & $6 \mathrm{H}-3 \mathrm{~A}, 135.0$ & 48.17 & $6 \mathrm{H}-3 \mathrm{~A}, 137.5$ & 48.20 & 48.19 & $6 \mathrm{H}-6 \mathrm{~A}, 43.5$ & 42.83 & $6 \mathrm{H}-6 \mathrm{~A}, 45.0$ & 42.85 & 42.84 \\
\hline $\mathrm{C} 16 \mathrm{r} / \mathrm{C} 17 \mathrm{n} .1 \mathrm{n}$ & 36.969 & $6 \mathrm{H}-3 \mathrm{~A}, 140.0$ & 48.22 & $6 \mathrm{H}-4 \mathrm{~A}, 10.0$ & 48.44 & 48.33 & $6 \mathrm{H}-6 \mathrm{~A}, 57.5$ & 42.98 & $6 \mathrm{H}-6 \mathrm{~A}, 60.0$ & 43.00 & 42.99 \\
\hline C17n.1n/C17n.1r & 37.753 & $6 \mathrm{H}-4 \mathrm{~A}, 140.0$ & 49.74 & $6 \mathrm{H}-5 \mathrm{~A}, 10.0$ & 49.96 & 49.85 & $6 \mathrm{H}-7 \mathrm{~A}, 45.0$ & 44.35 & $6 \mathrm{H}-7 \mathrm{~A}, 47.5$ & 44.38 & 44.37 \\
\hline $\mathrm{C} 17 n \cdot 1 \mathrm{r} / \mathrm{C} 17 n \cdot 2 \mathrm{n}$ & 37.872 & $6 \mathrm{H}-5 \mathrm{~A}, 25.0$ & 50.11 & $6 \mathrm{H}-5 \mathrm{~A}, 27.5$ & 50.14 & 50.13 & $\mathrm{NI}$ & $\mathrm{NI}$ & $\mathrm{NI}$ & $\mathrm{NI}$ & $\mathrm{NI}$ \\
\hline $\mathrm{C} 17 n .2 n / C 17 n \cdot 2 r$ & 38.093 & $6 \mathrm{H}-5 \mathrm{~A}, 45.0$ & 50.31 & $6 \mathrm{H}-5 \mathrm{~A}, 47.5$ & 50.34 & 50.33 & $\mathrm{NI}$ & $\mathrm{NI}$ & $\mathrm{NI}$ & $\mathrm{NI}$ & $\mathrm{NI}$ \\
\hline $\mathrm{C} 17 n .2 r / C 17 n .3 n$ & 38.159 & $6 \mathrm{H}-5 \mathrm{~A}, 52.5$ & 50.39 & $6 \mathrm{H}-5 \mathrm{~A}, 55.0$ & 50.41 & 50.40 & $\mathrm{NI}$ & $\mathrm{NI}$ & $\mathrm{NI}$ & $\mathrm{NI}$ & $\mathrm{NI}$ \\
\hline $\mathrm{C} 17 n \cdot 3 n / C 17 r$ & 38.333 & $6 \mathrm{H}-5 \mathrm{~A}, 82.5$ & 50.69 & $6 \mathrm{H}-5 \mathrm{~A}, 87.5$ & 50.74 & 50.72 & $\mathrm{NI}$ & $\mathrm{NI}$ & $\mathrm{NI}$ & $\mathrm{NI}$ & $\mathrm{NI}$ \\
\hline $\mathrm{C} 17 \mathrm{r} / \mathrm{C} 18 \mathrm{n} .1 \mathrm{n}$ & 38.615 & $6 \mathrm{H}-5 \mathrm{~A}, 122.5$ & 51.09 & $6 \mathrm{H}-5 \mathrm{~A}, 130.0$ & 51.16 & 51.13 & $\mathrm{NI}$ & $\mathrm{NI}$ & $\mathrm{NI}$ & $\mathrm{NI}$ & $\mathrm{NI}$ \\
\hline $\mathrm{C} 18 \mathrm{n} .1 \mathrm{n} / \mathrm{C} 18 \mathrm{n} .1 \mathrm{r}$ & 39.627 & $\mathrm{NI}$ & $\mathrm{NI}$ & $\mathrm{NI}$ & $\mathrm{NI}$ & $\mathrm{NI}$ & $7 \mathrm{H}-2 \mathrm{~A}, 122.5$ & 47.13 & $7 \mathrm{H}-2 \mathrm{~A}, 125.0$ & 47.15 & 47.14 \\
\hline $\mathrm{C} 18 n .1 \mathrm{r} / \mathrm{C} 18 n .2 n$ & 39.698 & $\mathrm{NI}$ & $\mathrm{NI}$ & $\mathrm{NI}$ & $\mathrm{NI}$ & $\mathrm{NI}$ & $7 \mathrm{H}-3 \mathrm{~A}, 22.5$ & 47.63 & $7 \mathrm{H}-3 \mathrm{~A}, 25.0$ & 47.65 & 47.64 \\
\hline $\mathrm{C} 18 n .2 n / C 18 r$ & 40.145 & $7 \mathrm{H}-1 \mathrm{~A}, 42.5$ & 53.73 & $7 \mathrm{H}-1 \mathrm{~A}, 52.5$ & 53.83 & 53.78 & $7 \mathrm{H}-3 \mathrm{~A}, 40.0$ & 47.80 & $7 \mathrm{H}-3 \mathrm{~A}, 42.5$ & 47.83 & 47.82 \\
\hline $\mathrm{C} 18 \mathrm{r} / \mathrm{C} 19 \mathrm{n}$ & 41.154 & $7 \mathrm{H}-4 \mathrm{~A}, 85.0$ & 58.65 & $7 \mathrm{H}-4 \mathrm{~A}, 87.5$ & 58.68 & 58.67 & $7 \mathrm{H}-6 \mathrm{~A}, 82.5$ & 52.73 & $7 \mathrm{H}-6 \mathrm{~A}, 85.0$ & 52.75 & 52.74 \\
\hline $\mathrm{C} 19 \mathrm{n} / \mathrm{C} 19 \mathrm{r}$ & 41.390 & $7 \mathrm{H}-5 \mathrm{~A}, 77.5$ & 60.08 & $7 \mathrm{H}-5 \mathrm{~A}, 80.0$ & 60.10 & 60.09 & $\mathrm{NI}$ & $\mathrm{NI}$ & $\mathrm{NI}$ & $\mathrm{NI}$ & $\mathrm{NI}$ \\
\hline C19r/C20n & 42.301 & $8 \mathrm{H}-2 \mathrm{~A}, 62.5$ & 64.93 & $6 \mathrm{H}-2 \mathrm{~A}, 67.5$ & 64.98 & 64.96 & $8 \mathrm{H}-5 \mathrm{~A}, 37.5$ & 60.28 & $8 \mathrm{H}-5 \mathrm{~A}, 40.0$ & 60.30 & 60.29 \\
\hline $\mathrm{C} 20 \mathrm{n} / \mathrm{C} 2 \mathrm{Or}$ & 43.432 & $9 \mathrm{H}-1 \mathrm{~A}, 140.0$ & 73.70 & $9 \mathrm{H}-2 \mathrm{~A}, 47.50$ & 74.28 & 73.99 & $9 \mathrm{H}-4 \mathrm{~A}, 130.0$ & 69.20 & $9 \mathrm{H}-4 \mathrm{~A}, 132.5$ & 69.23 & 69.22 \\
\hline $\mathrm{C} 20 \mathrm{r} / \mathrm{C} 21 \mathrm{n}$ & 45.724 & $12 \mathrm{H}-6 \mathrm{~A}, 132.5$ & 109.65 & $12 \mathrm{H}-6 \mathrm{~A}, 137.5$ & 109.70 & 109.68 & $13 \mathrm{H}-4 \mathrm{~A}, 85.0$ & 106.76 & $13 \mathrm{H}-4 \mathrm{~A}, 92.5$ & 106.84 & 106.80 \\
\hline $\mathrm{C} 21 \mathrm{n} / \mathrm{C} 21 \mathrm{r}$ & 47.349 & $15 \mathrm{H}-1 \mathrm{~A}, 102.5$ & 130.33 & $15 \mathrm{H}-1 \mathrm{~A}, 105.0$ & 130.35 & 130.34 & $15 \mathrm{H}-4 \mathrm{~A}, 110.0$ & 126.00 & $15 \mathrm{H}-4 \mathrm{~A}, 117.5$ & 126.08 & 126.04 \\
\hline $\mathrm{C} 21 \mathrm{r} / \mathrm{C} 22 \mathrm{n}$ & 48.566 & $15 \mathrm{H}-6 \mathrm{~A}, 102.5$ & 137.83 & $15 \mathrm{H}-6 \mathrm{~A}, 105.0$ & 137.85 & 137.84 & $16 \mathrm{H}-2 \mathrm{~A}, 140.0$ & 132.80 & $16 \mathrm{H}-3 \mathrm{~A}, 10.0$ & 133.00 & 132.90 \\
\hline $\mathrm{C} 22 \mathrm{n} / \mathrm{C} 22 \mathrm{r}$ & 49.344 & $16 \mathrm{H}-2 \mathrm{~A}, 10.0$ & 140.35 & $16 \mathrm{H}-2 \mathrm{~A}, 17.5$ & 140.25 & 140.30 & $16 \mathrm{H}-5 \mathrm{~A}, 97.5$ & 136.88 & $16 \mathrm{H}-5 \mathrm{~A}, 105.0$ & 136.95 & 136.91 \\
\hline
\end{tabular}

Ages from Gradstein et al. (2012). NI = not identified. 
Table T15. Summary of anisotropy of magnetic susceptibility of discrete samples, Hole U1403A. (Continued on next two pages.)

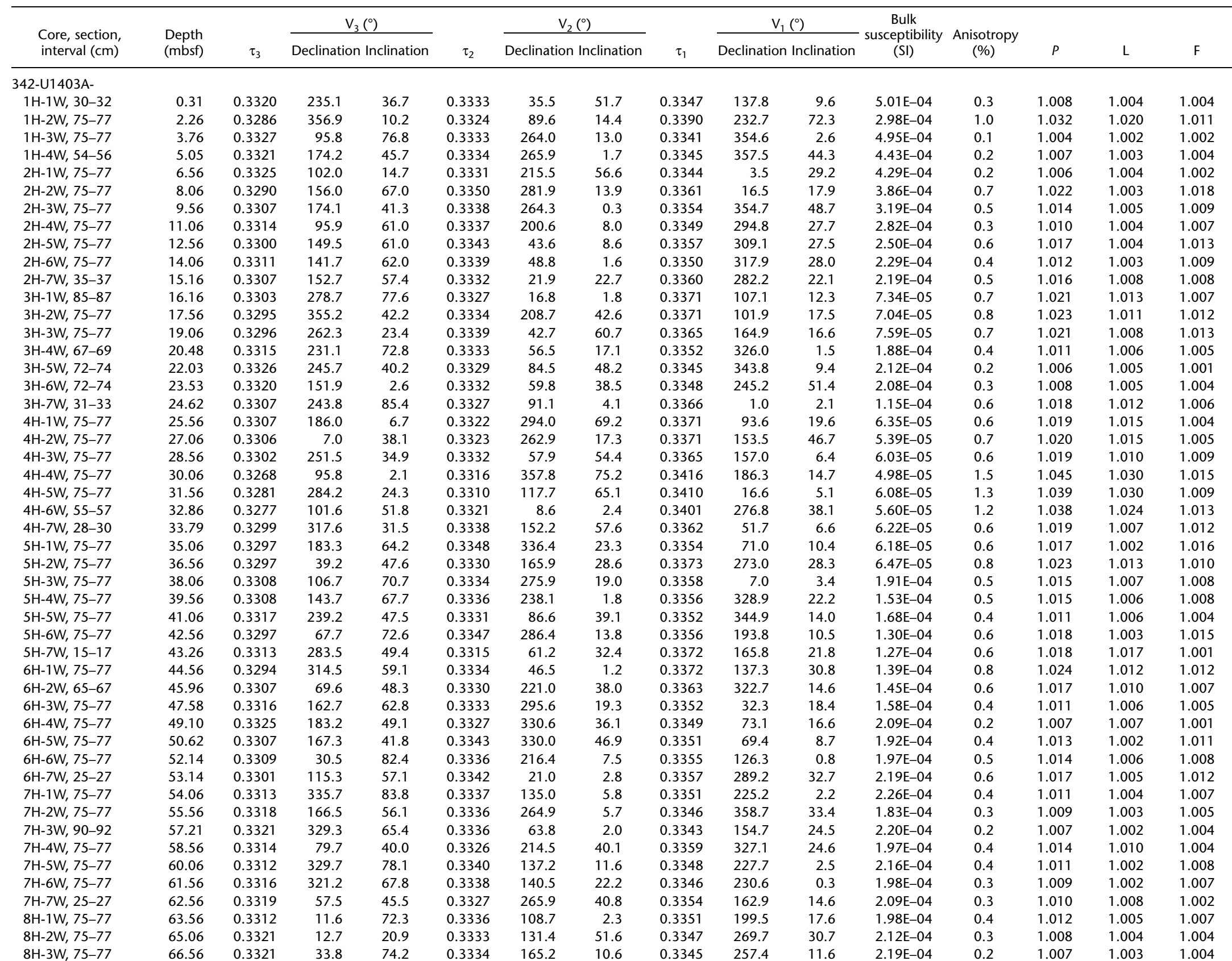


Table T15 (continued). (Continued on next page.)

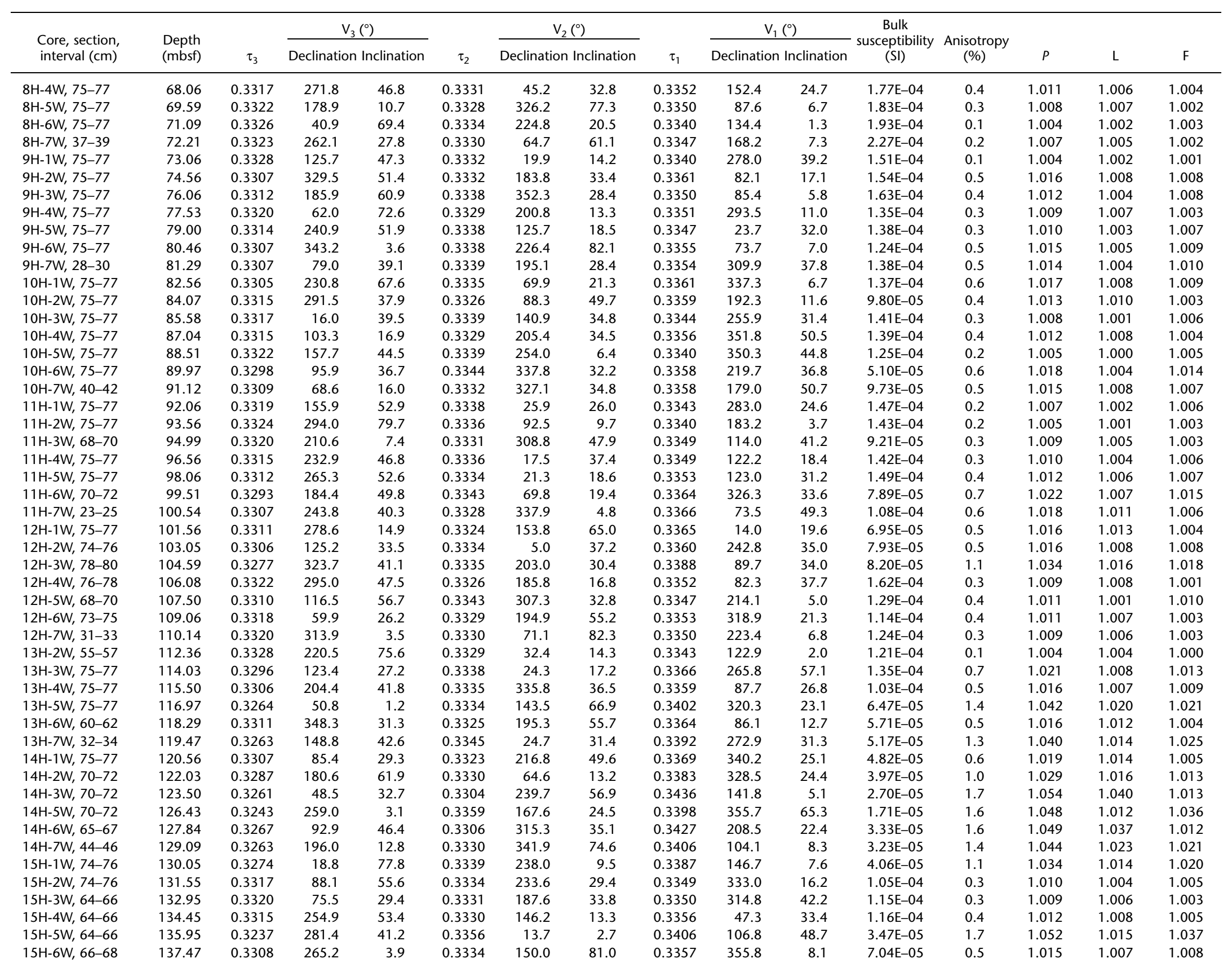


Table T15 (continued).

\begin{tabular}{|c|c|c|c|c|c|c|c|c|c|c|c|c|c|c|c|}
\hline \multirow{2}{*}{$\begin{array}{l}\text { Core, section, } \\
\text { interval }(\mathrm{cm})\end{array}$} & \multirow{2}{*}{$\begin{array}{l}\text { Depth } \\
\text { (mbsf) }\end{array}$} & \multirow[b]{2}{*}{$\tau_{3}$} & \multicolumn{2}{|c|}{$V_{3}\left({ }^{\circ}\right)$} & \multirow[b]{2}{*}{$\tau_{2}$} & \multicolumn{2}{|c|}{$V_{2}\left({ }^{\circ}\right)$} & \multirow[b]{2}{*}{$\tau_{1}$} & \multicolumn{2}{|c|}{$\mathrm{V}_{1}\left({ }^{\circ}\right)$} & \multirow{2}{*}{$\begin{array}{c}\text { Bulk } \\
\text { - susceptibility } \\
\text { (SI) }\end{array}$} & \multirow{2}{*}{$\begin{array}{c}\text { Anisotropy } \\
\text { (\%) }\end{array}$} & \multirow[b]{2}{*}{$P$} & \multirow[b]{2}{*}{$\mathrm{L}$} & \multirow[b]{2}{*}{$\mathrm{F}$} \\
\hline & & & Declinatior & nclination & & Declinatio & Inclination & & Declinatio & Inclination & & & & & \\
\hline $16 \mathrm{H}-1 \mathrm{~W}, 75-77$ & 139.56 & 0.3295 & 339.7 & 5.1 & 0.3343 & 244.0 & 48.7 & 0.3362 & 74.1 & 40.8 & $7.15 \mathrm{E}-05$ & 0.7 & 1.020 & 1.006 & 1.014 \\
\hline $16 \mathrm{H}-2 \mathrm{~W}, 75-77$ & 141.01 & 0.3305 & 248.9 & 63.1 & 0.3341 & 82.2 & 26.3 & 0.3354 & 349.6 & 5.4 & $1.28 \mathrm{E}-04$ & 0.5 & 1.015 & 1.004 & 1.011 \\
\hline $16 \mathrm{H}-3 \mathrm{~W}, 74-76$ & 142.45 & 0.3310 & 318.7 & 84.0 & 0.3323 & 187.8 & 3.9 & 0.3366 & 97.4 & 4.5 & $1.40 \mathrm{E}-04$ & 0.6 & 1.017 & 1.013 & 1.004 \\
\hline $16 \mathrm{H}-4 \mathrm{~W}, 74-76$ & 143.90 & 0.3313 & 128.6 & 77.3 & 0.3333 & 6.6 & 6.8 & 0.3354 & 275.3 & 10.6 & $1.33 \mathrm{E}-04$ & 0.4 & 1.012 & 1.006 & 1.006 \\
\hline $16 \mathrm{H}-5 \mathrm{~W}, 74-76$ & 145.35 & 0.3307 & 246.0 & 82.6 & 0.3335 & 347.1 & 1.4 & 0.3357 & 77.3 & 7.2 & $1.32 \mathrm{E}-04$ & 0.5 & 1.015 & 1.007 & 1.009 \\
\hline $16 \mathrm{H}-6 \mathrm{~W}, 74-76$ & 146.80 & 0.3296 & 321.5 & 67.2 & 0.3326 & 227.9 & 1.5 & 0.3379 & 137.3 & 22.8 & $1.25 \mathrm{E}-04$ & 0.8 & 1.025 & 1.016 & 1.009 \\
\hline $23 X-3 W, 24-26$ & 198.05 & 0.3273 & 102.5 & 80.8 & 0.3356 & 300.6 & 8.8 & 0.3371 & 210.2 & 2.8 & $4.68 \mathrm{E}-04$ & 1.0 & 1.030 & 1.004 & 1.026 \\
\hline $25 X-4 W, 63-65$ & 214.84 & 0.3295 & 5.0 & 76.9 & 0.3347 & 107.8 & 2.9 & 0.3358 & 198.4 & 12.7 & $4.16 \mathrm{E}-04$ & 0.6 & 1.019 & 1.003 & 1.016 \\
\hline 25X-5W, 114-116 & 216.85 & 0.3254 & 98.3 & 81.5 & 0.3371 & 224.0 & 5.0 & 0.3375 & 314.6 & 6.8 & 4.42E-04 & 1.2 & 1.037 & 1.001 & 1.036 \\
\hline $26 \mathrm{X}-1 \mathrm{~W}, 50-52$ & 215.01 & 0.3261 & 133.5 & 70.0 & 0.3366 & 233.1 & 3.5 & 0.3373 & 324.4 & 19.7 & $3.84 \mathrm{E}-04$ & 1.1 & 1.034 & 1.002 & 1.032 \\
\hline $26 \mathrm{X}-1 \mathrm{~W}, 130-132$ & 215.81 & 0.3270 & 150.5 & 83.6 & 0.3364 & 58.0 & 0.3 & 0.3366 & 328.0 & 6.4 & $4.46 \mathrm{E}-04$ & 1.0 & 1.029 & 1.000 & 1.029 \\
\hline $27 X-5 W, 31-33$ & 230.52 & 0.3296 & 182.2 & 76.2 & 0.3349 & 87.8 & 1.1 & 0.3355 & 357.6 & 13.8 & $2.20 \mathrm{E}-04$ & 0.6 & 1.018 & 1.002 & 1.016 \\
\hline $27 \mathrm{X}-6 \mathrm{~W}, 120-122$ & 232.91 & 0.3281 & 344.7 & 79.9 & 0.3355 & 145.2 & 9.6 & 0.3364 & 235.8 & 3.3 & $2.00 \mathrm{E}-04$ & 0.8 & 1.025 & 1.003 & 1.023 \\
\hline $28 X-5 W, 53-55$ & 240.44 & 0.3270 & 224.1 & 75.7 & 0.3365 & 89.1 & 10.2 & 0.3365 & 357.3 & 9.9 & $3.04 \mathrm{E}-04$ & 1.0 & 1.029 & 1.000 & 1.029 \\
\hline $28 X-6 W, 45-47$ & 241.86 & 0.3281 & 87.2 & 85.6 & 0.3350 & 255.3 & 4.3 & 0.3368 & 345.3 & 0.9 & $3.35 \mathrm{E}-04$ & 0.9 & 1.026 & 1.005 & 1.021 \\
\hline
\end{tabular}

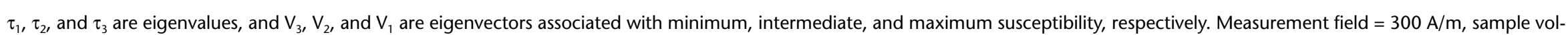
ume $=7 \mathrm{~cm}^{3}$. $P=$ anisotropy degree, $\mathrm{L}=$ lineation, $\mathrm{F}=$ foliation 
Table T16. Summary of anisotropy of magnetic susceptibility of discrete samples, Hole U1403B. (Continued on next page.)

\begin{tabular}{|c|c|c|c|c|c|c|c|c|c|c|c|c|c|c|c|}
\hline \multirow{2}{*}{$\begin{array}{l}\text { Core, section, } \\
\text { interval }(\mathrm{cm})\end{array}$} & \multirow{2}{*}{$\begin{array}{l}\text { Depth } \\
\text { (mbsf) }\end{array}$} & \multirow[b]{2}{*}{$\tau_{3}$} & \multirow{2}{*}{\multicolumn{2}{|c|}{$\frac{\mathrm{V}_{3}\left({ }^{\circ}\right)}{\text { Declination Inclination }}$}} & \multirow[b]{2}{*}{$\tau_{2}$} & \multirow{2}{*}{\multicolumn{2}{|c|}{$\frac{\mathrm{V}_{2}\left(^{\circ}\right)}{\text { Declination Inclination }}$}} & \multirow[b]{2}{*}{$\tau_{1}$} & \multirow{2}{*}{\multicolumn{2}{|c|}{$\frac{\mathrm{V}_{1}\left({ }^{\circ}\right)}{\text { Declination Inclination }}$}} & \multirow{2}{*}{$\begin{array}{l}\text { Bulk } \\
\text { susceptibility } \\
\text { (SI) }\end{array}$} & \multirow{2}{*}{$\begin{array}{l}\text { Anisotropy } \\
\text { (\%) }\end{array}$} & \multirow[b]{2}{*}{$P$} & \multirow[b]{2}{*}{$\mathrm{L}$} & \multirow[b]{2}{*}{$\mathrm{F}$} \\
\hline & & & & & & & & & & & & & & & \\
\hline \multicolumn{16}{|l|}{ 342-U1403B- } \\
\hline 19H-1W, 74-76 & 151.15 & 0.3307 & 182.8 & 51.4 & 0.3339 & 39.3 & 32.7 & 0.3354 & 297.1 & 18.2 & $1.98 \mathrm{E}-04$ & 0.5 & 1.014 & 1.005 & 1.009 \\
\hline $19 \mathrm{H}-2 \mathrm{~W}, 101-103$ & 152.92 & 0.3285 & 129.0 & 76.2 & 0.3354 & 31.6 & 1.8 & 0.3361 & 301.1 & 13.7 & $3.01 \mathrm{E}-04$ & 0.8 & 1.023 & 1.002 & 1.021 \\
\hline $19 \mathrm{H}-3 \mathrm{~W}, 48-50$ & 153.89 & 0.3283 & 99.2 & 71.0 & 0.3357 & 325.8 & 13.3 & 0.3359 & 232.6 & 13.3 & $2.88 \mathrm{E}-04$ & 0.8 & 1.023 & 1.001 & 1.023 \\
\hline $19 \mathrm{H}-4 \mathrm{~W}, 47-49$ & 154.81 & 0.3283 & 111.6 & 80.4 & 0.3353 & 5.6 & 2.7 & 0.3363 & 275.1 & 9.3 & 2.87E-04 & 0.8 & 1.024 & 1.003 & 1.021 \\
\hline $20 \mathrm{H}-1 \mathrm{~W}, 65-67$ & 155.66 & 0.3311 & 179.5 & 75.1 & 0.3338 & 74.1 & 4.0 & 0.3350 & 343.0 & 14.3 & $2.20 \mathrm{E}-04$ & 0.4 & 1.012 & 1.004 & 1.008 \\
\hline $20 \mathrm{H}-2 \mathrm{~W}, 74-76$ & 157.25 & 0.3270 & 59.6 & 70.6 & 0.3364 & 238.4 & 19.4 & 0.3366 & 328.5 & 0.4 & $3.43 \mathrm{E}-04$ & 1.0 & 1.029 & 1.001 & 1.029 \\
\hline $20 \mathrm{H}-3 \mathrm{~W}, 60-62$ & 158.61 & 0.3288 & 233.1 & 82.1 & 0.3347 & 333.0 & 1.4 & 0.3365 & 63.1 & 7.7 & $3.52 \mathrm{E}-04$ & 0.8 & 1.023 & 1.006 & 1.018 \\
\hline $20 \mathrm{H}-4 \mathrm{~W}, 70-72$ & 160.21 & 0.3287 & 132.4 & 82.0 & 0.3354 & 330.4 & 7.6 & 0.3359 & 240.1 & 2.5 & $3.16 \mathrm{E}-04$ & 0.7 & 1.022 & 1.001 & 1.021 \\
\hline $20 \mathrm{H}-5 \mathrm{~W}, 62-64$ & 161.64 & 0.3318 & 338.9 & 70.1 & 0.3338 & 186.7 & 17.7 & 0.3344 & 93.9 & 8.7 & $2.49 \mathrm{E}-04$ & 0.3 & 1.008 & 1.002 & 1.006 \\
\hline $20 \mathrm{H}-6 \mathrm{~W}, 54-56$ & 163.08 & 0.3313 & 138.5 & 27.1 & 0.3333 & 261.9 & 47.0 & 0.3354 & 31.0 & 30.5 & $7.83 \mathrm{E}-05$ & 0.4 & 1.012 & 1.006 & 1.006 \\
\hline $21 \mathrm{H}-1 \mathrm{~W}, 74-76$ & 164.75 & 0.3266 & 38.8 & 55.4 & 0.3342 & 286.8 & 14.6 & 0.3392 & 187.9 & 30.7 & $7.99 \mathrm{E}-05$ & 1.3 & 1.039 & 1.015 & 1.024 \\
\hline $21 \mathrm{H}-2 \mathrm{~W}, 74-76$ & 166.25 & 0.3307 & 217.8 & 52.9 & 0.3323 & 322.0 & 10.5 & 0.3370 & 59.5 & 35.1 & $9.59 \mathrm{E}-05$ & 0.6 & 1.019 & 1.014 & 1.005 \\
\hline $21 \mathrm{H}-3 \mathrm{~W}, 78-80$ & 167.79 & 0.3288 & 306.3 & 20.3 & 0.3344 & 183.6 & 55.7 & 0.3368 & 46.9 & 26.4 & $7.69 \mathrm{E}-05$ & 0.8 & 1.024 & 1.007 & 1.017 \\
\hline $21 \mathrm{H}-4 \mathrm{~W}, 74-76$ & 169.25 & 0.3284 & 225.0 & 65.0 & 0.3344 & 47.8 & 24.9 & 0.3373 & 317.3 & 1.1 & $6.64 \mathrm{E}-05$ & 0.9 & 1.027 & 1.009 & 1.018 \\
\hline $21 \mathrm{H}-5 \mathrm{~W}, 74-76$ & 170.75 & 0.3319 & 71.5 & 58.2 & 0.3327 & 240.4 & 31.3 & 0.3355 & 333.4 & 5.0 & $8.92 \mathrm{E}-05$ & 0.4 & 1.011 & 1.009 & 1.002 \\
\hline $21 \mathrm{H}-6 \mathrm{~W}, 55-57$ & 172.06 & 0.3311 & 343.1 & 74.1 & 0.3343 & 200.8 & 12.7 & 0.3345 & 108.6 & 9.4 & $1.23 \mathrm{E}-04$ & 0.3 & 1.010 & 1.001 & 1.010 \\
\hline $21 \mathrm{H}-7 \mathrm{~W}, 24-26$ & 172.75 & 0.3314 & 291.8 & 28.8 & 0.3339 & 87.9 & 58.9 & 0.3347 & 195.9 & 10.6 & $1.16 \mathrm{E}-04$ & 0.3 & 1.010 & 1.002 & 1.008 \\
\hline $22 \mathrm{H}-1 \mathrm{~W}, 70-72$ & 173.71 & 0.3314 & 266.1 & 50.3 & 0.3324 & 101.6 & 38.7 & 0.3361 & 5.4 & 7.6 & $1.63 \mathrm{E}-04$ & 0.5 & 1.014 & 1.011 & 1.003 \\
\hline $23 \mathrm{X}-1 \mathrm{~W}, 125-127$ & 190.07 & 0.3312 & 102.1 & 68.5 & 0.3339 & 291.4 & 21.3 & 0.3349 & 200.2 & 3.2 & $4.12 \mathrm{E}-04$ & 0.4 & 1.011 & 1.003 & 1.008 \\
\hline $23 \mathrm{X}-2 \mathrm{~W}, 70-72$ & 195.91 & 0.3275 & 87.2 & 82.7 & 0.3359 & 293.2 & 6.6 & 0.3366 & 202.9 & 3.2 & $4.13 \mathrm{E}-04$ & 0.9 & 1.028 & 1.002 & 1.026 \\
\hline $23 X-3 W, 30-32$ & 177.16 & 0.3312 & 166.8 & 77.4 & 0.3340 & 15.7 & 11.1 & 0.3348 & 284.5 & 6.0 & $3.18 \mathrm{E}-04$ & 0.4 & 1.011 & 1.002 & 1.008 \\
\hline $24 X-1 W, 99-101$ & 178.11 & 0.3293 & 205.8 & 81.1 & 0.3349 & 89.1 & 4.0 & 0.3357 & 358.5 & 7.9 & $4.54 \mathrm{E}-04$ & 0.6 & 1.019 & 1.002 & 1.017 \\
\hline $25 X-2 W, 106-108$ & 178.81 & 0.3304 & 119.2 & 82.5 & 0.3344 & 213.3 & 0.5 & 0.3352 & 303.4 & 7.5 & $4.03 \mathrm{E}-04$ & 0.5 & 1.014 & 1.002 & 1.012 \\
\hline $25 \mathrm{X}-6 \mathrm{~W}, 90-92$ & 185.50 & 0.3310 & 169.5 & 36.8 & 0.3323 & 335.3 & 52.4 & 0.3367 & 74.3 & 6.9 & $1.20 \mathrm{E}-04$ & 0.6 & 1.017 & 1.013 & 1.004 \\
\hline $28 X-3 W, 70-72$ & 220.31 & 0.3315 & 147.8 & 78.4 & 0.3332 & 319.4 & 11.5 & 0.3353 & 49.8 & 1.6 & $1.80 \mathrm{E}-04$ & 0.4 & 1.012 & 1.006 & 1.005 \\
\hline $28 X-3 W, 130-132$ & 220.91 & 0.3297 & 65.7 & 83.3 & 0.3346 & 326.8 & 1.0 & 0.3358 & 236.7 & 6.6 & $1.97 \mathrm{E}-04$ & 0.6 & 1.019 & 1.003 & 1.015 \\
\hline $29 X-1 W, 62-64$ & 226.93 & 0.3277 & 275.7 & 86.7 & 0.3354 & 19.4 & 0.8 & 0.3369 & 109.4 & 3.2 & $2.83 \mathrm{E}-04$ & 0.9 & 1.028 & 1.005 & 1.023 \\
\hline 29X-1W, 134-136 & 227.65 & 0.3297 & 162.5 & 82.1 & 0.3347 & 253.8 & 0.2 & 0.3355 & 343.8 & 7.9 & $2.80 \mathrm{E}-04$ & 0.6 & 1.018 & 1.002 & 1.015 \\
\hline 29X-2W, 90-92 & 228.71 & 0.3287 & 263.7 & 81.7 & 0.3354 & 356.3 & 0.4 & 0.3359 & 86.3 & 8.3 & $2.54 \mathrm{E}-04$ & 0.7 & 1.022 & 1.001 & 1.021 \\
\hline $29 X-3 W, 63-65$ & 229.94 & 0.3285 & 296.1 & 85.4 & 0.3353 & 168.8 & 2.8 & 0.3362 & 78.6 & 3.7 & $2.06 \mathrm{E}-04$ & 0.8 & 1.024 & 1.003 & 1.021 \\
\hline $29 X-4 W, 101-103$ & 231.82 & 0.3293 & 154.4 & 70.9 & 0.3348 & 272.1 & 9.1 & 0.3359 & 4.8 & 16.6 & $1.76 \mathrm{E}-04$ & 0.7 & 1.020 & 1.003 & 1.017 \\
\hline $29 X-5 W, 25-27$ & 232.56 & 0.3263 & 125.2 & 83.9 & 0.3367 & 15.9 & 2.0 & 0.3370 & 285.7 & 5.8 & $2.58 \mathrm{E}-04$ & 1.1 & 1.033 & 1.001 & 1.032 \\
\hline $29 X-5 W, 75-77$ & 233.06 & 0.3237 & 266.2 & 3.6 & 0.3370 & 176.2 & 0.2 & 0.3392 & 82.9 & 86.4 & $5.02 \mathrm{E}-04$ & 1.6 & 1.048 & 1.007 & 1.041 \\
\hline $30 X-1 W, 72-74$ & 236.73 & 0.3231 & 125.5 & 82.8 & 0.3384 & 234.1 & 2.3 & 0.3385 & 324.4 & 6.8 & 4.60E-04 & 1.5 & 1.048 & 1.000 & 1.047 \\
\hline $30 X-2 W, 61-63$ & 238.12 & 0.3305 & 348.4 & 70.6 & 0.3334 & 129.5 & 15.4 & 0.3361 & 222.8 & 11.6 & $1.94 \mathrm{E}-04$ & 0.6 & 1.017 & 1.008 & 1.009 \\
\hline $30 X-3 W, 44-46$ & 239.45 & 0.3310 & 272.6 & 66.0 & 0.3339 & 4.4 & 0.8 & 0.3351 & 94.8 & 24.0 & $1.90 \mathrm{E}-04$ & 0.4 & 1.012 & 1.004 & 1.009 \\
\hline $30 X-4 W, 30-32$ & 240.81 & 0.3263 & 135.1 & 81.7 & 0.3362 & 285.9 & 7.3 & 0.3375 & 16.4 & 4.0 & $2.83 \mathrm{E}-04$ & 1.1 & 1.034 & 1.004 & 1.030 \\
\hline $31 X-1 W, 78-80$ & 246.49 & 0.3301 & 56.6 & 47.0 & 0.3346 & 164.5 & 16.0 & 0.3353 & 267.7 & 38.6 & $1.91 \mathrm{E}-04$ & 0.5 & 1.016 & 1.002 & 1.014 \\
\hline $31 X-2 W, 60-62$ & 247.81 & 0.3294 & 107.1 & 79.0 & 0.3347 & 11.4 & 1.1 & 0.3358 & 281.1 & 11.0 & $2.68 \mathrm{E}-04$ & 0.6 & 1.019 & 1.003 & 1.016 \\
\hline
\end{tabular}


Table T16 (continued).

\begin{tabular}{|c|c|c|c|c|c|c|c|c|c|c|c|c|c|c|c|}
\hline \multirow{2}{*}{$\begin{array}{l}\text { Core, section, } \\
\text { interval }(\mathrm{cm})\end{array}$} & \multirow{2}{*}{$\begin{array}{l}\text { Depth } \\
\text { (mbsf) }\end{array}$} & \multirow[b]{2}{*}{$\tau_{3}$} & \multicolumn{2}{|c|}{$V_{3}\left({ }^{\circ}\right)$} & \multirow[b]{2}{*}{$\tau_{2}$} & \multicolumn{2}{|c|}{$V_{2}\left(^{\circ}\right)$} & \multirow[b]{2}{*}{$\tau_{1}$} & \multicolumn{2}{|c|}{$\mathrm{V}_{1}\left({ }^{\circ}\right)$} & \multirow{2}{*}{$\begin{array}{c}\text { Bulk } \\
\text { susceptibility } \\
\text { (SI) }\end{array}$} & \multirow{2}{*}{$\begin{array}{l}\text { Anisotropy } \\
(\%)\end{array}$} & \multirow[b]{2}{*}{$P$} & \multirow[b]{2}{*}{ L } & \multirow[b]{2}{*}{$\mathrm{F}$} \\
\hline & & & Declination & nclination & & Declination & Inclination & & Declination & Inclination & & & & & \\
\hline $32 X-2 W, 90-92$ & 257.81 & 0.3257 & 132.2 & 84.1 & 0.3362 & 353.6 & 4.4 & 0.3381 & 263.3 & 3.9 & $4.11 \mathrm{E}-04$ & 1.2 & 1.038 & 1.006 & 1.032 \\
\hline $32 X-3 W, 43-45$ & 258.84 & 0.3255 & 173.1 & 86.9 & 0.3369 & 302.0 & 1.9 & 0.3375 & 32.1 & 2.4 & $3.23 \mathrm{E}-04$ & 1.2 & 1.037 & 1.002 & 1.035 \\
\hline $32 X-4 W, 58-60$ & 260.49 & 0.3237 & 117.9 & 85.8 & 0.3378 & 290.6 & 4.2 & 0.3386 & 20.7 & 0.5 & $4.31 \mathrm{E}-04$ & 1.5 & 1.046 & 1.002 & 1.044 \\
\hline $32 X-5 W, 16-18$ & 261.27 & 0.3243 & 143.9 & 88.9 & 0.3376 & 275.2 & 0.8 & 0.3381 & 5.2 & 0.9 & $3.72 \mathrm{E}-04$ & 1.4 & 1.043 & 1.002 & 1.041 \\
\hline
\end{tabular}

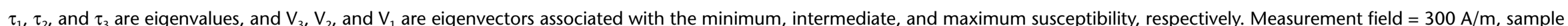
volume $=7 \mathrm{~cm}^{3}$. $P=$ anisotropy degree, $L=$ lineation, $F=$ foliation. 
Table T17. Biostratigraphic and magnetostratigraphic datums, Hole U1403A. (Continued on next page.)

\begin{tabular}{|c|c|c|c|c|c|c|c|}
\hline \multirow{2}{*}{$\begin{array}{l}\text { Datum tie } \\
\text { point }\end{array}$} & \multirow[b]{2}{*}{ Datum } & \multirow[b]{2}{*}{ Datum type } & \multirow[b]{2}{*}{ Zone/Subzone } & \multirow{2}{*}{$\begin{array}{l}\text { Age } \\
(\mathrm{Ma})\end{array}$} & \multicolumn{3}{|c|}{ Depth (mbsf) } \\
\hline & & & & & Top & Bottom & Mid-point \\
\hline \multirow[t]{6}{*}{ D01 } & T Pseudoemiliania lacunosa & Calcareous nannofossil & NN20 & 0.44 & 0.45 & 1.30 & 0.88 \\
\hline & T Calcidiscus macintyrei & Calcareous nannofossil & & 1.61 & 1.30 & 1.95 & 1.63 \\
\hline & T Discoaster brouweri & Calcareous nannofossil & NN19 & 1.93 & 1.95 & 2.20 & 2.08 \\
\hline & T Discoaster sublodoensis & Calcareous nannofossil & NP15a & 46.29 & 118.68 & 119.39 & 119.04 \\
\hline & B Nannotetrina cristata & Calcareous nannofossil & & 47.73 & 129.69 & 131.70 & 130.70 \\
\hline & B Discoaster sublodoensis & Calcareous nannofossil & NP14 & 49.11 & 134.55 & 136.16 & 135.36 \\
\hline \multirow[t]{19}{*}{ D09 } & T Tribrachiatus orthostylus & Calcareous nannofossil & NP13 & 50.50 & 147.75 & 147.80 & 147.78 \\
\hline & B Discoaster lodoensis & Calcareous nannofossil & NP12 & 53.70 & 148.76 & 156.46 & 152.61 \\
\hline & T Tribrachiatus contortus & Calcareous nannofossil & NP11 & 54.17 & 159.10 & 160.88 & 159.99 \\
\hline & B Tribrachiatus orthostylus & Calcareous nannofossil & & 54.37 & 165.60 & 166.48 & 166.04 \\
\hline & B Discoaster diastypus & Calcareous nannofossil & & 54.95 & 176.28 & 177.18 & 176.73 \\
\hline & B Tribrachiatus contortus & Calcareous nannofossil & & 54.95 & 166.48 & 167.30 & 166.89 \\
\hline & T Fasciculithus spp. & Calcareous nannofossil & & 55.64 & 177.78 & 178.68 & 178.23 \\
\hline & B Rhomboaster bramlettei & Calcareous nannofossil & NP10 & 55.86 & 176.28 & 177.18 & 176.73 \\
\hline & B Rhomboaster spp. & Calcareous nannofossil & P/E boundary & 55.96 & 181.68 & 182.23 & 181.96 \\
\hline & B Sphenolithus moriformis & Calcareous nannofossil & & 61.98 & 203.40 & 203.40 & 203.40 \\
\hline & B Fasciculithus first radiation & Calcareous nannofossil & & 62.13 & 210.85 & 216.45 & 213.65 \\
\hline & B Prinsius tenuiculus* & Calcareous nannofossil & & 64.81 & 216.20 & 218.34 & 217.27 \\
\hline & B Chiasmolithus danicus & Calcareous nannofossil & NP3 & 64.81 & 218.30 & 214.70 & 216.50 \\
\hline & B Cruciplacolithus intermedius & Calcareous nannofossil & NP2 & 65.47 & 218.34 & 219.74 & 219.04 \\
\hline & B Cruciplacolithus primus $(3.5-5 \mu \mathrm{m})$ & Calcareous nannofossil & & 65.76 & 219.74 & 220.53 & 220.14 \\
\hline & B Neobiscutum parvulum & Calcareous nannofossil & & 65.90 & 220.53 & 220.55 & 220.54 \\
\hline & $\begin{array}{l}\text { T Micula murus, other Cretaceous } \\
\text { nannofossils }\end{array}$ & Calcareous nannofossil & $\mathrm{K} / \mathrm{Pg}$ boundary & 66.04 & 220.59 & 220.63 & 220.61 \\
\hline & B Biantholithus sparsus; Ba calcispheres & Calcareous nannofossil & $\mathrm{K} / \mathrm{Pg}$ boundary & 66.04 & 220.59 & 220.63 & 220.61 \\
\hline & B Micula prinsii & Calcareous nannofossil & UC20dT & 67.30 & 220.10 & 223.10 & 221.60 \\
\hline \multirow[t]{3}{*}{ D12 } & B Ceratolithoides kamptneri & Calcareous nannofossil & UC20cT & 67.84 & 223.10 & 224.42 & 223.76 \\
\hline & B Micula murus & Calcareous nannofossil & UC20bT & 69.00 & 240.90 & 242.25 & 241.58 \\
\hline & B Cribrocorona gallica & Calcareous nannofossil & & 69.00 & 234.63 & 240.90 & 237.77 \\
\hline \multirow[t]{2}{*}{ D13 } & T Reinhardtites levis & Calcareous nannofossil & UC19 & 70.14 & 247.81 & 249.22 & 248.52 \\
\hline & T Uniplanarius trifidus & Calcareous nannofossil & $\sim \mathrm{UC18}$ & 71.31 & 249.22 & 250.38 & 249.80 \\
\hline D14 & T Broinsonia parca constricta & Calcareous nannofossil & UC17 & 72.02 & 249.22 & 250.38 & 249.80 \\
\hline \multirow[t]{20}{*}{ D15 } & B Uniplanarius trifidus & Calcareous nannofossil & UC15dT & 76.82 & 258.68 & 258.68 & 258.68 \\
\hline & B Sethochytris triconiscus & Radiolarian & & 42.69 & 110.87 & 120.23 & 115.55 \\
\hline & B Podocyrtis fasciolata & Radiolarian & & 43.50 & 63.98 & 66.91 & 65.45 \\
\hline & B Eusyringium fistuligerum & Radiolarian & RP13 & 44.46 & 63.98 & 66.91 & 65.45 \\
\hline & T Podocyrtis diamesa & Radiolarian & & 45.63 & 101.13 & 110.87 & 106.00 \\
\hline & $\mathrm{T}$ Theocotyle nigriniae & Radiolarian & & 45.63 & 110.87 & 120.23 & 115.55 \\
\hline & T Thyrsocyrtis hirsuta & Radiolarian & & 45.63 & 81.80 & 91.91 & 86.85 \\
\hline & $\mathrm{X}$ Thyrsocyrtis tensa $-T$. triacantha & Radiolarian & & 46.21 & 91.91 & 101.13 & 96.52 \\
\hline & B Eusyringium lagena & Radiolarian & RP12 & 46.21 & 101.13 & 110.87 & 106.00 \\
\hline & B Dictyoprora mongolfieri & Radiolarian & RP11 & 47.98 & 110.87 & 120.23 & 115.55 \\
\hline & $\mathrm{X}$ Theocotyle nigriniae $-T$. cryptocephala & Radiolarian & RP10 & 48.57 & 120.23 & 129.77 & 125.00 \\
\hline & B Thyrsocyrtis rhizodon & Radiolarian & & 49.46 & 147.78 & 147.83 & 147.80 \\
\hline & B Podocyrtis diamesa & Radiolarian & & 49.75 & 138.41 & 147.78 & 143.09 \\
\hline & B Theocorys anaclasta & Radiolarian & & 50.05 & 120.23 & 129.77 & 125.00 \\
\hline & B Lychnocanoma bellum & Radiolarian & RP9 & 50.05 & 148.77 & 165.63 & 157.20 \\
\hline & T Bekoma bidartensis & Radiolarian & & 50.87 & 165.63 & 175.45 & 170.54 \\
\hline & T Buryella tetradica & Radiolarian & & 50.87 & 148.77 & 165.63 & 157.20 \\
\hline & B Thyrsocyrtis tensa & Radiolarian & & 51.70 & 129.77 & 138.41 & 134.09 \\
\hline & B Theocotylissa ficus & Radiolarian & & 51.70 & 138.41 & 147.78 & 143.09 \\
\hline & B Calocyclas hispida & Radiolarian & & 52.52 & 138.41 & 147.78 & 143.09 \\
\hline D10 & B Spongatractus balbis & Radiolarian & & 53.35 & 147.78 & 147.83 & 147.80 \\
\hline & B Theocotyle nigriniae & Radiolarian & & 53.35 & 147.78 & 147.83 & 147.80 \\
\hline & B Thyrsocyrtis hirsuta & Radiolarian & RP8 & 53.35 & 165.63 & 175.45 & 170.54 \\
\hline & B Calocycloma castum & Radiolarian & & 55.40 & 165.63 & 175.45 & 170.54 \\
\hline & T Amphisphaera goruna & Radiolarian & & 55.50 & 148.77 & 165.63 & 157.20 \\
\hline & B Theocorys phyzella & Radiolarian & & 55.90 & 185.14 & 188.69 & 186.91 \\
\hline D11 & B Podocyrtis papalis & Radiolarian & & 55.96 & 185.14 & 188.69 & 186.91 \\
\hline & B Amphicraspedum prolixum & Radiolarian & & 56.14 & 185.14 & 188.69 & 186.91 \\
\hline & $\mathrm{X}$ Bekoma campechensis - B. bidartensis & Radiolarian & RP7 & 58.23 & 175.45 & 185.14 & 180.29 \\
\hline & B Buryella tetradica & Radiolarian & & 62.20 & 204.32 & 204.32 & 204.32 \\
\hline & B Amphisphaera coronata & Radiolarian & & 63.00 & 204.32 & 204.32 & 204.32 \\
\hline & B Morozovella angulata & Planktonic for & & 62.29 & 203.65 & 204.34 & 204.00 \\
\hline & T Globotruncana bulloides & Planktonic foraminifer & & 68.40 & 228.41 & 229.94 & 229.18 \\
\hline & T Globotruncana linneana & Planktonic foraminifer & & 70.90 & 233.19 & 234.68 & 233.94 \\
\hline & B Contusotruncana contusa & Planktonic foraminifer & & 71.00 & 246.27 & 248.15 & 247.21 \\
\hline
\end{tabular}


Table T17 (continued).

\begin{tabular}{|c|c|c|c|c|c|c|c|}
\hline \multirow{2}{*}{$\begin{array}{c}\text { Datum tie } \\
\text { point }\end{array}$} & \multirow[b]{2}{*}{ Datum } & \multirow[b]{2}{*}{ Datum type } & \multirow[b]{2}{*}{ Zone/Subzone } & \multirow{2}{*}{$\begin{array}{l}\text { Age } \\
(\mathrm{Ma})\end{array}$} & \multicolumn{3}{|c|}{ Depth (mbsf) } \\
\hline & & & & & Top & Bottom & Mid-point \\
\hline \multirow[t]{8}{*}{ D02 } & C16n.1r/C16n.2n & Chron boundary & & 36.05 & 46.48 & 46.65 & 46.57 \\
\hline & $\mathrm{C} 16 \mathrm{n} \cdot 2 \mathrm{n} / \mathrm{C} 16 \mathrm{r}$ & Chron boundary & & 36.70 & 48.17 & 48.20 & 48.19 \\
\hline & C16r/C17n.1n & Chron boundary & & 36.97 & 48.22 & 48.44 & 48.33 \\
\hline & C17n.1n/C17n.1r & Chron boundary & & 37.75 & 49.74 & 49.96 & 49.85 \\
\hline & C17n.1r/C17n.2n & Chron boundary & & 37.87 & 50.11 & 50.14 & 50.13 \\
\hline & C17n.2n/C17n.2r & Chron boundary & & 38.09 & 50.31 & 50.34 & 50.33 \\
\hline & C17n.2r/C17n.3n & Chron boundary & & 38.16 & 50.39 & 50.41 & 50.40 \\
\hline & C17n.3n/C17r & Chron boundary & & 38.33 & 50.69 & 50.74 & 50.72 \\
\hline \multirow[t]{2}{*}{ D03 } & C17r/C18n.1n & Chron boundary & & 38.62 & 51.09 & 51.16 & 51.13 \\
\hline & $\mathrm{C} 18 n .2 n / C 18 r$ & Chron boundary & & 40.14 & 53.73 & 53.83 & 53.78 \\
\hline D04 & C18r/C19n & Chron boundary & & 41.15 & 58.65 & 58.68 & 58.67 \\
\hline \multirow[t]{2}{*}{ D05 } & $\mathrm{C} 19 \mathrm{n} / \mathrm{C} 19 \mathrm{r}$ & Chron boundary & & 41.39 & 60.08 & 60.10 & 60.09 \\
\hline & C19r/C20n & Chron boundary & & 42.30 & 64.93 & 64.98 & 64.96 \\
\hline D06 & $\mathrm{C} 20 \mathrm{n} / \mathrm{C} 20 \mathrm{r}$ & Chron boundary & & 43.43 & 73.70 & 74.28 & 73.99 \\
\hline D07 & $C 20 r / C 21 n$ & Chron boundary & & 45.72 & 109.65 & 109.70 & 109.68 \\
\hline \multirow[t]{3}{*}{ D08 } & $\mathrm{C} 21 \mathrm{n} / \mathrm{C} 21 \mathrm{r}$ & Chron boundary & & 47.35 & 130.33 & 130.35 & 130.34 \\
\hline & $C 21 r / C 22 n$ & Chron boundary & & 48.57 & 137.83 & 137.85 & 137.84 \\
\hline & $\mathrm{C} 22 \mathrm{n} / \mathrm{C} 22 \mathrm{r}$ & Chron boundary & & 49.34 & 140.35 & 140.25 & 140.30 \\
\hline
\end{tabular}

* = interpolated age. $\mathrm{T}=$ top, $\mathrm{B}=$ base, $\mathrm{Ba}=$ base of acme, $\mathrm{X}=$ faunal crossover.

Table T18. Age-depth model datum tie points, Hole U1403A.

\begin{tabular}{|c|c|c|c|c|c|c|c|c|c|}
\hline $\begin{array}{l}\text { Datum } \\
\text { tie point }\end{array}$ & Datum & Datum type & $\begin{array}{l}\text { Zone/ } \\
\text { Subzone }\end{array}$ & $\begin{array}{l}\text { Age } \\
(\mathrm{Ma})\end{array}$ & $\begin{array}{l}\text { Mid-point } \\
\text { depth } \\
\text { (mbsf) }\end{array}$ & $\begin{array}{l}\text { Distance } \\
(\mathrm{m})\end{array}$ & $\begin{array}{l}\text { Duration } \\
\text { (Ma) }\end{array}$ & $\begin{array}{c}\text { LSR } \\
(\mathrm{cm} / \mathrm{k} . \mathrm{y} .)\end{array}$ & Notes \\
\hline D01 & T Pseudoemiliania lacunosa & Calcareous nannofossil & NN20 & 0.44 & 0.88 & & & & \\
\hline D02 & C16n.1r/C16n.2n & Chron boundary & & 36.05 & 46.57 & 45.69 & 35.61 & 0.13 & \\
\hline D03 & $\mathrm{C} 17 \mathrm{r} / \mathrm{C} 18 \mathrm{n} .1 \mathrm{n}$ & Chron boundary & & 38.62 & 51.13 & 4.56 & 2.56 & 0.18 & Average rate $=0.24$ \\
\hline D04 & C18r/C19n & Chron boundary & & 41.15 & 58.67 & 7.54 & 2.54 & 0.30 & $\mathrm{~cm} / \mathrm{k} . \mathrm{y}$. \\
\hline D05 & $\mathrm{C} 19 n / C 19 r$ & Chron boundary & & 41.39 & 60.09 & 1.43 & 0.24 & 0.61 & Average rate $=0.64$ \\
\hline D06 & $\mathrm{C} 20 \mathrm{n} / \mathrm{C} 20 \mathrm{r}$ & Chron boundary & & 43.43 & 73.99 & 13.90 & 2.04 & 0.68 & $\mathrm{~cm} / \mathrm{k} . \mathrm{y}$. \\
\hline D07 & C20r/C21n & Chron boundary & & 45.72 & 109.68 & 35.69 & 2.29 & 1.56 & \\
\hline D08 & $\mathrm{C} 21 \mathrm{n} / \mathrm{C} 21 \mathrm{r}$ & Chron boundary & & 47.35 & 130.34 & 20.66 & 1.62 & 1.27 & \\
\hline D09 & T Tribrachiatus orthostylus & Calcareous nannofossil & NP13 & 50.50 & 147.78 & 17.44 & 3.15 & 0.55 & \\
\hline D10 & B Spongatractus balbis & Radiolarian & & 53.35 & 147.80 & 0.03 & 2.85 & 0.00 & Hiatus \\
\hline D11 & B Podocyrtis papalis & Radiolarian & & 55.96 & 186.91 & 39.11 & 2.61 & 1.50 & \\
\hline D12 & B Ceratolithoides kamptneri & Calcareous nannofossil & UC20cT & 67.84 & 223.76 & 36.85 & 11.88 & 0.31 & \\
\hline D13 & T Reinhardtites levis & Calcareous nannofossil & UC19 & 70.14 & 248.52 & 24.76 & 2.30 & 1.08 & \\
\hline D14 & T Broinsonia parca constricta & Calcareous nannofossil & UC17 & 72.02 & 249.80 & 1.29 & 1.88 & 0.07 & Hiatus \\
\hline D15 & B Uniplanarius trifidus & Calcareous nannofossil & UC15dT & 76.82 & 258.68 & 8.88 & 4.80 & 0.19 & \\
\hline
\end{tabular}

$\mathrm{LSR}=$ linear sedimentation rate. $\mathrm{T}=$ top, $\mathrm{B}=$ base. 
Table T19. Carbonate content and accumulation rates, Site U1403. (Continued on next four pages.)

\begin{tabular}{|c|c|c|c|c|c|c|}
\hline $\begin{array}{l}\text { Age } \\
(\mathrm{Ma})\end{array}$ & $\begin{array}{c}\text { LSR } \\
(\mathrm{cm} / \mathrm{k} \cdot \mathrm{y} .)\end{array}$ & $\begin{array}{l}\text { Dry density } \\
\left(\mathrm{g} / \mathrm{cm}^{3}\right)\end{array}$ & $\begin{array}{l}\mathrm{CaCO}_{3} \\
(\mathrm{wt} \%)\end{array}$ & $\begin{array}{c}\text { MAR } \\
\left(\mathrm{cm} / \mathrm{m}^{2} / \mathrm{k} . \mathrm{y} .\right)\end{array}$ & $\begin{array}{c}\text { CAR } \\
\left(\mathrm{cm} / \mathrm{m}^{2} / \mathrm{k} . \mathrm{y} .\right)\end{array}$ & $\begin{array}{c}n C A R \\
\left(\mathrm{~cm} / \mathrm{m}^{2} / \mathrm{k} \cdot \mathrm{y} .\right)\end{array}$ \\
\hline 1.2 & 0.13 & 0.84 & 25.64 & 0.108 & 0.028 & 0.080 \\
\hline 1.4 & 0.13 & 0.83 & 21.51 & 0.106 & 0.023 & 0.083 \\
\hline 1.6 & 0.13 & 0.81 & 17.39 & 0.104 & 0.018 & 0.086 \\
\hline 1.8 & 0.13 & 0.80 & 13.26 & 0.102 & 0.014 & 0.089 \\
\hline 2.0 & 0.13 & 0.78 & 9.13 & 0.100 & 0.009 & 0.091 \\
\hline 2.2 & 0.13 & 0.76 & 5.00 & 0.098 & 0.005 & 0.093 \\
\hline 2.4 & 0.13 & 0.75 & 1.20 & 0.096 & 0.001 & 0.095 \\
\hline 2.6 & 0.13 & 0.75 & 0.45 & 0.097 & 0.000 & 0.096 \\
\hline 2.8 & 0.13 & 0.76 & 0.45 & 0.097 & 0.000 & 0.097 \\
\hline 3.0 & 0.13 & 0.76 & 0.44 & 0.097 & 0.000 & 0.097 \\
\hline 3.2 & 0.13 & 0.76 & 0.43 & 0.098 & 0.000 & 0.097 \\
\hline 3.4 & 0.13 & 0.77 & 0.43 & 0.098 & 0.000 & 0.098 \\
\hline 3.6 & 0.13 & 0.77 & 0.42 & 0.099 & 0.000 & 0.098 \\
\hline 3.8 & 0.13 & 0.77 & 0.42 & 0.099 & 0.000 & 0.099 \\
\hline 4.0 & 0.13 & 0.78 & 0.42 & 0.100 & 0.000 & 0.099 \\
\hline 4.2 & 0.13 & 0.78 & 0.43 & 0.100 & 0.000 & 0.100 \\
\hline 4.4 & 0.13 & 0.78 & 0.43 & 0.101 & 0.000 & 0.100 \\
\hline 4.6 & 0.13 & 0.79 & 0.42 & 0.101 & 0.000 & 0.101 \\
\hline 4.8 & 0.13 & 0.79 & 0.37 & 0.101 & 0.000 & 0.101 \\
\hline 5.0 & 0.13 & 0.79 & 0.32 & 0.102 & 0.000 & 0.101 \\
\hline 5.2 & 0.13 & 0.79 & 0.27 & 0.102 & 0.000 & 0.102 \\
\hline 5.4 & 0.13 & 0.80 & 0.22 & 0.102 & 0.000 & 0.102 \\
\hline 5.6 & 0.13 & 0.80 & 0.18 & 0.102 & 0.000 & 0.102 \\
\hline 5.8 & 0.13 & 0.79 & 0.19 & 0.102 & 0.000 & 0.101 \\
\hline 6.0 & 0.13 & 0.78 & 0.22 & 0.100 & 0.000 & 0.100 \\
\hline 6.2 & 0.13 & 0.77 & 0.25 & 0.098 & 0.000 & 0.098 \\
\hline 6.4 & 0.13 & 0.75 & 0.27 & 0.097 & 0.000 & 0.096 \\
\hline 6.6 & 0.13 & 0.74 & 0.30 & 0.095 & 0.000 & 0.095 \\
\hline 6.8 & 0.13 & 0.73 & 0.33 & 0.093 & 0.000 & 0.093 \\
\hline 7.0 & 0.13 & 0.72 & 0.33 & 0.093 & 0.000 & 0.093 \\
\hline 7.2 & 0.13 & 0.73 & 0.32 & 0.094 & 0.000 & 0.094 \\
\hline 7.4 & 0.13 & 0.74 & 0.31 & 0.095 & 0.000 & 0.095 \\
\hline 7.6 & 0.13 & 0.75 & 0.30 & 0.096 & 0.000 & 0.096 \\
\hline 7.8 & 0.13 & 0.75 & 0.29 & 0.097 & 0.000 & 0.096 \\
\hline 8.0 & 0.13 & 0.76 & 0.28 & 0.098 & 0.000 & 0.097 \\
\hline 8.2 & 0.13 & 0.77 & 0.28 & 0.098 & 0.000 & 0.098 \\
\hline 8.4 & 0.13 & 0.77 & 0.28 & 0.099 & 0.000 & 0.098 \\
\hline 8.6 & 0.13 & 0.77 & 0.28 & 0.099 & 0.000 & 0.099 \\
\hline 8.8 & 0.13 & 0.78 & 0.29 & 0.100 & 0.000 & 0.099 \\
\hline 9.0 & 0.13 & 0.78 & 0.29 & 0.100 & 0.000 & 0.100 \\
\hline 9.2 & 0.13 & 0.78 & 0.29 & 0.100 & 0.000 & 0.100 \\
\hline 9.4 & 0.13 & 0.78 & 0.31 & 0.100 & 0.000 & 0.100 \\
\hline 9.6 & 0.13 & 0.78 & 0.33 & 0.100 & 0.000 & 0.100 \\
\hline 9.8 & 0.13 & 0.78 & 0.34 & 0.100 & 0.000 & 0.099 \\
\hline 10.0 & 0.13 & 0.77 & 0.36 & 0.099 & 0.000 & 0.099 \\
\hline 10.2 & 0.13 & 0.77 & 0.38 & 0.099 & 0.000 & 0.098 \\
\hline 10.4 & 0.13 & 0.77 & 0.40 & 0.098 & 0.000 & 0.098 \\
\hline 10.6 & 0.13 & 0.76 & 0.39 & 0.097 & 0.000 & 0.097 \\
\hline 10.8 & 0.13 & 0.75 & 0.38 & 0.096 & 0.000 & 0.096 \\
\hline 11.0 & 0.13 & 0.74 & 0.37 & 0.095 & 0.000 & 0.095 \\
\hline 11.2 & 0.13 & 0.73 & 0.36 & 0.094 & 0.000 & 0.094 \\
\hline 11.4 & 0.13 & 0.72 & 0.35 & 0.092 & 0.000 & 0.092 \\
\hline 11.6 & 0.13 & 0.68 & 0.34 & 0.087 & 0.000 & 0.087 \\
\hline 11.8 & 0.13 & 0.64 & 0.34 & 0.082 & 0.000 & 0.081 \\
\hline 12.0 & 0.13 & 0.60 & 0.34 & 0.077 & 0.000 & 0.076 \\
\hline 12.2 & 0.13 & 0.59 & 0.33 & 0.076 & 0.000 & 0.076 \\
\hline 12.4 & 0.13 & 0.60 & 0.33 & 0.077 & 0.000 & 0.076 \\
\hline 12.6 & 0.13 & 0.60 & 0.32 & 0.077 & 0.000 & 0.077 \\
\hline 12.8 & 0.13 & 0.60 & 0.32 & 0.077 & 0.000 & 0.077 \\
\hline 13.0 & 0.13 & 0.61 & 0.31 & 0.078 & 0.000 & 0.077 \\
\hline 13.2 & 0.13 & 0.61 & 0.29 & 0.078 & 0.000 & 0.078 \\
\hline 13.4 & 0.13 & 0.62 & 0.25 & 0.079 & 0.000 & 0.079 \\
\hline 13.6 & 0.13 & 0.63 & 0.21 & 0.081 & 0.000 & 0.080 \\
\hline 13.8 & 0.13 & 0.64 & 0.17 & 0.082 & 0.000 & 0.082 \\
\hline 14.0 & 0.13 & 0.65 & 0.13 & 0.083 & 0.000 & 0.083 \\
\hline 14.2 & 0.13 & 0.66 & 0.09 & 0.085 & 0.000 & 0.084 \\
\hline 14.4 & 0.13 & 0.65 & 0.09 & 0.084 & 0.000 & 0.083 \\
\hline 14.6 & 0.13 & 0.62 & 0.14 & 0.080 & 0.000 & 0.080 \\
\hline 14.8 & 0.13 & 0.60 & 0.18 & 0.077 & 0.000 & 0.077 \\
\hline
\end{tabular}


Table T19 (continued). (Continued on next page.)

\begin{tabular}{|c|c|c|c|c|c|c|}
\hline $\begin{array}{l}\text { Age } \\
(\mathrm{Ma})\end{array}$ & $\begin{array}{c}\text { LSR } \\
(\mathrm{cm} / \mathrm{k} . \mathrm{y} .)\end{array}$ & $\begin{array}{l}\text { Dry density } \\
\left(\mathrm{g} / \mathrm{cm}^{3}\right)\end{array}$ & $\begin{array}{l}\mathrm{CaCO}_{3} \\
\text { (wt\%) }\end{array}$ & $\begin{array}{c}\text { MAR } \\
\left(\mathrm{cm} / \mathrm{m}^{2} / \mathrm{k} . \mathrm{y} .\right)\end{array}$ & $\begin{array}{c}\text { CAR } \\
\left(\mathrm{cm} / \mathrm{m}^{2} / \mathrm{k} . \mathrm{y} .\right)\end{array}$ & $\begin{array}{c}\mathrm{nCAR} \\
\left(\mathrm{cm} / \mathrm{m}^{2} / \mathrm{k} \cdot \mathrm{y} .\right)\end{array}$ \\
\hline 15.0 & 0.13 & 0.57 & 0.22 & 0.073 & 0.000 & 0.073 \\
\hline 15.2 & 0.13 & 0.55 & 0.26 & 0.070 & 0.000 & 0.070 \\
\hline 15.4 & 0.13 & 0.52 & 0.30 & 0.067 & 0.000 & 0.067 \\
\hline 15.6 & 0.13 & 0.51 & 0.32 & 0.065 & 0.000 & 0.065 \\
\hline 15.8 & 0.13 & 0.51 & 0.33 & 0.065 & 0.000 & 0.065 \\
\hline 16.0 & 0.13 & 0.51 & 0.34 & 0.065 & 0.000 & 0.065 \\
\hline 16.2 & 0.13 & 0.51 & 0.35 & 0.065 & 0.000 & 0.065 \\
\hline 16.4 & 0.13 & 0.51 & 0.37 & 0.066 & 0.000 & 0.065 \\
\hline 16.6 & 0.13 & 0.51 & 0.38 & 0.066 & 0.000 & 0.066 \\
\hline 16.8 & 0.13 & 0.52 & 0.36 & 0.066 & 0.000 & 0.066 \\
\hline 17.0 & 0.13 & 0.53 & 0.34 & 0.067 & 0.000 & 0.067 \\
\hline 17.2 & 0.13 & 0.53 & 0.33 & 0.069 & 0.000 & 0.068 \\
\hline 17.4 & 0.13 & 0.54 & 0.31 & 0.070 & 0.000 & 0.069 \\
\hline 17.6 & 0.13 & 0.55 & 0.29 & 0.071 & 0.000 & 0.071 \\
\hline 17.8 & 0.13 & 0.56 & 0.27 & 0.071 & 0.000 & 0.071 \\
\hline 18.0 & 0.13 & 0.54 & 0.27 & 0.070 & 0.000 & 0.069 \\
\hline 18.2 & 0.13 & 0.53 & 0.27 & 0.067 & 0.000 & 0.067 \\
\hline 18.4 & 0.13 & 0.51 & 0.27 & 0.065 & 0.000 & 0.065 \\
\hline 18.6 & 0.13 & 0.49 & 0.27 & 0.063 & 0.000 & 0.063 \\
\hline 18.8 & 0.13 & 0.47 & 0.27 & 0.061 & 0.000 & 0.061 \\
\hline 19.0 & 0.13 & 0.47 & 0.26 & 0.060 & 0.000 & 0.060 \\
\hline 19.2 & 0.13 & 0.47 & 0.24 & 0.060 & 0.000 & 0.060 \\
\hline 19.4 & 0.13 & 0.47 & 0.23 & 0.060 & 0.000 & 0.060 \\
\hline 19.6 & 0.13 & 0.47 & 0.25 & 0.060 & 0.000 & 0.060 \\
\hline 19.8 & 0.13 & 0.47 & 0.28 & 0.061 & 0.000 & 0.060 \\
\hline 20.0 & 0.13 & 0.48 & 0.31 & 0.061 & 0.000 & 0.061 \\
\hline 20.2 & 0.13 & 0.48 & 0.33 & 0.061 & 0.000 & 0.061 \\
\hline 20.4 & 0.13 & 0.48 & 0.36 & 0.062 & 0.000 & 0.061 \\
\hline 20.6 & 0.13 & 0.49 & 0.37 & 0.062 & 0.000 & 0.062 \\
\hline 20.8 & 0.13 & 0.50 & 0.36 & 0.064 & 0.000 & 0.064 \\
\hline 21.0 & 0.13 & 0.52 & 0.34 & 0.066 & 0.000 & 0.066 \\
\hline 21.2 & 0.13 & 0.53 & 0.33 & 0.068 & 0.000 & 0.068 \\
\hline 21.4 & 0.13 & 0.55 & 0.31 & 0.070 & 0.000 & 0.070 \\
\hline 21.6 & 0.13 & 0.56 & 0.30 & 0.072 & 0.000 & 0.072 \\
\hline 21.8 & 0.13 & 0.56 & 0.27 & 0.072 & 0.000 & 0.072 \\
\hline 22.0 & 0.13 & 0.55 & 0.24 & 0.070 & 0.000 & 0.070 \\
\hline 22.2 & 0.13 & 0.53 & 0.20 & 0.068 & 0.000 & 0.068 \\
\hline 22.4 & 0.13 & 0.52 & 0.16 & 0.067 & 0.000 & 0.066 \\
\hline 22.6 & 0.13 & 0.50 & 0.13 & 0.065 & 0.000 & 0.065 \\
\hline 22.8 & 0.13 & 0.49 & 0.09 & 0.063 & 0.000 & 0.063 \\
\hline 23.0 & 0.13 & 0.49 & 0.12 & 0.063 & 0.000 & 0.063 \\
\hline 23.2 & 0.13 & 0.51 & 0.18 & 0.065 & 0.000 & 0.065 \\
\hline 23.4 & 0.13 & 0.52 & 0.24 & 0.067 & 0.000 & 0.067 \\
\hline 23.6 & 0.13 & 0.54 & 0.29 & 0.069 & 0.000 & 0.069 \\
\hline 23.8 & 0.13 & 0.56 & 0.35 & 0.072 & 0.000 & 0.071 \\
\hline 24.0 & 0.13 & 0.58 & 0.41 & 0.074 & 0.000 & 0.074 \\
\hline 24.2 & 0.13 & 0.58 & 0.41 & 0.075 & 0.000 & 0.075 \\
\hline 24.4 & 0.13 & 0.58 & 0.40 & 0.075 & 0.000 & 0.075 \\
\hline 24.6 & 0.13 & 0.58 & 0.39 & 0.075 & 0.000 & 0.075 \\
\hline 24.8 & 0.13 & 0.58 & 0.38 & 0.075 & 0.000 & 0.075 \\
\hline 25.0 & 0.13 & 0.58 & 0.37 & 0.075 & 0.000 & 0.075 \\
\hline 25.2 & 0.13 & 0.58 & 0.36 & 0.075 & 0.000 & 0.075 \\
\hline 25.4 & 0.13 & 0.58 & 0.36 & 0.075 & 0.000 & 0.074 \\
\hline 25.6 & 0.13 & 0.58 & 0.36 & 0.074 & 0.000 & 0.074 \\
\hline 25.8 & 0.13 & 0.58 & 0.36 & 0.074 & 0.000 & 0.074 \\
\hline 26.0 & 0.13 & 0.58 & 0.35 & 0.074 & 0.000 & 0.074 \\
\hline 26.2 & 0.13 & 0.58 & 0.33 & 0.074 & 0.000 & 0.074 \\
\hline 26.4 & 0.13 & 0.58 & 0.31 & 0.074 & 0.000 & 0.074 \\
\hline 26.6 & 0.13 & 0.58 & 0.28 & 0.075 & 0.000 & 0.074 \\
\hline 26.8 & 0.13 & 0.58 & 0.26 & 0.075 & 0.000 & 0.075 \\
\hline 27.0 & 0.13 & 0.59 & 0.27 & 0.076 & 0.000 & 0.075 \\
\hline 27.2 & 0.13 & 0.60 & 0.29 & 0.076 & 0.000 & 0.076 \\
\hline 27.4 & 0.13 & 0.60 & 0.32 & 0.077 & 0.000 & 0.077 \\
\hline 27.6 & 0.13 & 0.61 & 0.35 & 0.078 & 0.000 & 0.078 \\
\hline 27.8 & 0.13 & 0.61 & 0.38 & 0.079 & 0.000 & 0.078 \\
\hline 28.0 & 0.13 & 0.62 & 0.40 & 0.080 & 0.000 & 0.079 \\
\hline 28.2 & 0.13 & 0.63 & 0.40 & 0.080 & 0.000 & 0.080 \\
\hline 28.4 & 0.13 & 0.63 & 0.39 & 0.081 & 0.000 & 0.081 \\
\hline 28.6 & 0.13 & 0.64 & 0.39 & 0.082 & 0.000 & 0.081 \\
\hline
\end{tabular}


Table T19 (continued). (Continued on next page.)

\begin{tabular}{|c|c|c|c|c|c|c|}
\hline $\begin{array}{l}\text { Age } \\
\text { (Ma) }\end{array}$ & $\begin{array}{c}\text { LSR } \\
(\mathrm{cm} / \mathrm{k} \cdot \mathrm{y} .)\end{array}$ & $\begin{array}{l}\text { Dry density } \\
\left(\mathrm{g} / \mathrm{cm}^{3}\right)\end{array}$ & $\begin{array}{c}\mathrm{CaCO}_{3} \\
(\mathrm{wt} \%)\end{array}$ & $\begin{array}{c}\text { MAR } \\
\left(\mathrm{cm} / \mathrm{m}^{2} / \mathrm{k} . \mathrm{y} .\right)\end{array}$ & $\begin{array}{c}\text { CAR } \\
\left(\mathrm{cm} / \mathrm{m}^{2} / \mathrm{k} . \mathrm{y} .\right)\end{array}$ & $\begin{array}{c}\mathrm{nCAR} \\
\left(\mathrm{cm} / \mathrm{m}^{2} / \mathrm{k} \cdot \mathrm{y} \cdot\right)\end{array}$ \\
\hline 28.8 & 0.13 & 0.64 & 0.39 & 0.082 & 0.000 & 0.082 \\
\hline 29.0 & 0.13 & 0.65 & 0.38 & 0.083 & 0.000 & 0.083 \\
\hline 29.2 & 0.13 & 0.66 & 0.37 & 0.084 & 0.000 & 0.084 \\
\hline 29.4 & 0.13 & 0.67 & 0.31 & 0.086 & 0.000 & 0.086 \\
\hline 29.6 & 0.13 & 0.68 & 0.26 & 0.087 & 0.000 & 0.087 \\
\hline 29.8 & 0.13 & 0.70 & 0.21 & 0.089 & 0.000 & 0.089 \\
\hline 30.0 & 0.13 & 0.71 & 0.15 & 0.091 & 0.000 & 0.091 \\
\hline 30.2 & 0.13 & 0.72 & 0.10 & 0.093 & 0.000 & 0.092 \\
\hline 30.4 & 0.13 & 0.73 & 0.07 & 0.094 & 0.000 & 0.094 \\
\hline 30.6 & 0.13 & 0.74 & 0.07 & 0.095 & 0.000 & 0.095 \\
\hline 30.8 & 0.13 & 0.74 & 0.07 & 0.095 & 0.000 & 0.095 \\
\hline 31.0 & 0.13 & 0.75 & 0.06 & 0.096 & 0.000 & 0.096 \\
\hline 31.2 & 0.13 & 0.76 & 0.06 & 0.097 & 0.000 & 0.097 \\
\hline 31.4 & 0.13 & 0.76 & 0.06 & 0.098 & 0.000 & 0.098 \\
\hline 31.6 & 0.13 & 0.77 & 0.08 & 0.098 & 0.000 & 0.098 \\
\hline 31.8 & 0.13 & 0.77 & 0.13 & 0.098 & 0.000 & 0.098 \\
\hline 32.0 & 0.13 & 0.77 & 0.17 & 0.098 & 0.000 & 0.098 \\
\hline 32.2 & 0.13 & 0.77 & 0.21 & 0.099 & 0.000 & 0.098 \\
\hline 32.4 & 0.13 & 0.77 & 0.25 & 0.099 & 0.000 & 0.099 \\
\hline 32.6 & 0.13 & 0.78 & 0.30 & 0.100 & 0.000 & 0.099 \\
\hline 32.8 & 0.13 & 0.77 & 0.29 & 0.099 & 0.000 & 0.099 \\
\hline 33.0 & 0.13 & 0.77 & 0.25 & 0.099 & 0.000 & 0.099 \\
\hline 33.2 & 0.13 & 0.77 & 0.22 & 0.098 & 0.000 & 0.098 \\
\hline 33.4 & 0.13 & 0.76 & 0.19 & 0.098 & 0.000 & 0.098 \\
\hline 33.6 & 0.13 & 0.76 & 0.22 & 0.098 & 0.000 & 0.097 \\
\hline 33.8 & 0.13 & 0.76 & 0.26 & 0.097 & 0.000 & 0.097 \\
\hline 34.0 & 0.13 & 0.75 & 0.31 & 0.097 & 0.000 & 0.096 \\
\hline 34.2 & 0.13 & 0.75 & 0.35 & 0.097 & 0.000 & 0.096 \\
\hline 34.4 & 0.13 & 0.77 & 0.37 & 0.098 & 0.000 & 0.098 \\
\hline 34.6 & 0.13 & 0.78 & 0.38 & 0.100 & 0.000 & 0.100 \\
\hline 34.8 & 0.13 & 0.80 & 0.39 & 0.102 & 0.000 & 0.102 \\
\hline 35.0 & 0.13 & 0.81 & 0.39 & 0.104 & 0.000 & 0.104 \\
\hline 35.2 & 0.13 & 0.83 & 0.40 & 0.106 & 0.000 & 0.105 \\
\hline 35.4 & 0.13 & 0.83 & 0.40 & 0.107 & 0.000 & 0.107 \\
\hline 35.6 & 0.13 & 0.81 & 0.34 & 0.104 & 0.000 & 0.104 \\
\hline 35.8 & 0.13 & 0.79 & 0.27 & 0.101 & 0.000 & 0.100 \\
\hline 36.0 & 0.13 & 0.76 & 0.20 & 0.097 & 0.000 & 0.097 \\
\hline 36.2 & 0.18 & 0.73 & 0.13 & 0.130 & 0.000 & 0.130 \\
\hline 36.4 & 0.18 & 0.71 & 0.08 & 0.126 & 0.000 & 0.126 \\
\hline 36.6 & 0.18 & 0.71 & 0.13 & 0.126 & 0.000 & 0.125 \\
\hline 36.8 & 0.18 & 0.71 & 0.21 & 0.126 & 0.000 & 0.126 \\
\hline 37.0 & 0.18 & 0.71 & 0.28 & 0.127 & 0.000 & 0.126 \\
\hline 37.2 & 0.18 & 0.72 & 0.36 & 0.127 & 0.000 & 0.127 \\
\hline 37.4 & 0.18 & 0.72 & 0.39 & 0.127 & 0.000 & 0.127 \\
\hline 37.6 & 0.18 & 0.72 & 0.38 & 0.127 & 0.000 & 0.127 \\
\hline 37.8 & 0.18 & 0.71 & 0.37 & 0.127 & 0.000 & 0.127 \\
\hline 38.0 & 0.18 & 0.71 & 0.36 & 0.127 & 0.000 & 0.126 \\
\hline 38.2 & 0.18 & 0.71 & 0.34 & 0.126 & 0.000 & 0.125 \\
\hline 38.4 & 0.18 & 0.70 & 0.30 & 0.124 & 0.000 & 0.123 \\
\hline 38.6 & 0.18 & 0.68 & 0.26 & 0.122 & 0.000 & 0.121 \\
\hline 38.8 & 0.30 & 0.67 & 0.22 & 0.200 & 0.000 & 0.199 \\
\hline 39.0 & 0.30 & 0.66 & 0.27 & 0.197 & 0.001 & 0.197 \\
\hline 39.2 & 0.30 & 0.66 & 0.33 & 0.195 & 0.001 & 0.194 \\
\hline 39.4 & 0.30 & 0.72 & 0.16 & 0.212 & 0.000 & 0.212 \\
\hline 39.6 & 0.30 & 0.77 & 0.04 & 0.229 & 0.000 & 0.229 \\
\hline 39.8 & 0.30 & 0.76 & 0.05 & 0.225 & 0.000 & 0.225 \\
\hline 40.0 & 0.30 & 0.75 & 0.05 & 0.222 & 0.000 & 0.222 \\
\hline 40.2 & 0.30 & 0.76 & 0.06 & 0.225 & 0.000 & 0.225 \\
\hline 40.4 & 0.30 & 0.77 & 0.07 & 0.229 & 0.000 & 0.229 \\
\hline 40.6 & 0.30 & 0.77 & 0.14 & 0.228 & 0.000 & 0.228 \\
\hline 40.8 & 0.30 & 0.75 & 0.26 & 0.223 & 0.001 & 0.222 \\
\hline 41.0 & 0.30 & 0.73 & 0.37 & 0.218 & 0.001 & 0.217 \\
\hline 41.2 & 0.61 & 0.73 & 0.39 & 0.444 & 0.002 & 0.442 \\
\hline 41.4 & 0.68 & 0.72 & 0.39 & 0.487 & 0.002 & 0.485 \\
\hline 41.6 & 0.68 & 0.68 & 0.28 & 0.461 & 0.001 & 0.459 \\
\hline 41.8 & 0.68 & 0.75 & 0.09 & 0.510 & 0.000 & 0.509 \\
\hline 42.0 & 0.68 & 0.77 & 0.24 & 0.525 & 0.001 & 0.523 \\
\hline 42.2 & 0.68 & 0.78 & 0.34 & 0.530 & 0.002 & 0.528 \\
\hline 42.4 & 0.68 & 0.80 & 0.36 & 0.546 & 0.002 & 0.544 \\
\hline
\end{tabular}


Table T19 (continued). (Continued on next page.)

\begin{tabular}{|c|c|c|c|c|c|c|}
\hline $\begin{array}{l}\text { Age } \\
(\mathrm{Ma})\end{array}$ & $\begin{array}{c}\text { LSR } \\
(\mathrm{cm} / \mathrm{k} . \mathrm{y} .)\end{array}$ & $\begin{array}{l}\text { Dry density } \\
\left(\mathrm{g} / \mathrm{cm}^{3}\right)\end{array}$ & $\begin{array}{l}\mathrm{CaCO}_{3} \\
\text { (wt\%) }\end{array}$ & $\begin{array}{c}\text { MAR } \\
\left(\mathrm{cm} / \mathrm{m}^{2} / \mathrm{k} . \mathrm{y} .\right)\end{array}$ & $\begin{array}{c}\text { CAR } \\
\left(\mathrm{cm} / \mathrm{m}^{2} / \mathrm{k} . \mathrm{y} .\right)\end{array}$ & $\begin{array}{c}\mathrm{nCAR} \\
\left(\mathrm{cm} / \mathrm{m}^{2} / \mathrm{k} \cdot \mathrm{y} .\right)\end{array}$ \\
\hline 42.6 & 0.68 & 0.80 & 0.34 & 0.541 & 0.002 & 0.540 \\
\hline 42.8 & 0.68 & 0.78 & 0.34 & 0.529 & 0.002 & 0.528 \\
\hline 43.0 & 0.68 & 0.78 & 0.36 & 0.529 & 0.002 & 0.527 \\
\hline 43.2 & 0.68 & 0.72 & 0.35 & 0.491 & 0.002 & 0.490 \\
\hline 43.4 & 0.68 & 0.67 & 0.45 & 0.455 & 0.002 & 0.453 \\
\hline 43.6 & 1.56 & 0.64 & 0.39 & 0.990 & 0.004 & 0.987 \\
\hline 43.8 & 1.56 & 0.59 & 0.24 & 0.924 & 0.002 & 0.922 \\
\hline 44.0 & 1.56 & 0.57 & 0.34 & 0.887 & 0.003 & 0.884 \\
\hline 44.2 & 1.56 & 0.60 & 0.37 & 0.927 & 0.003 & 0.924 \\
\hline 44.4 & 1.56 & 0.62 & 0.41 & 0.972 & 0.004 & 0.968 \\
\hline 44.6 & 1.56 & 0.64 & 0.32 & 0.996 & 0.003 & 0.993 \\
\hline 44.8 & 1.56 & 0.68 & 0.35 & 1.054 & 0.004 & 1.050 \\
\hline 45.0 & 1.56 & 0.68 & 0.36 & 1.057 & 0.004 & 1.053 \\
\hline 45.2 & 1.56 & 0.79 & 0.66 & 1.237 & 0.008 & 1.229 \\
\hline 45.4 & 1.56 & 0.79 & 0.56 & 1.236 & 0.007 & 1.229 \\
\hline 45.6 & 1.56 & 0.77 & 0.54 & 1.191 & 0.006 & 1.185 \\
\hline 45.8 & 1.27 & 0.70 & 1.67 & 0.891 & 0.015 & 0.876 \\
\hline 46.0 & 1.27 & 0.69 & 0.47 & 0.883 & 0.004 & 0.878 \\
\hline 46.2 & 1.27 & 0.68 & 0.41 & 0.864 & 0.004 & 0.861 \\
\hline 46.4 & 1.27 & 0.60 & 2.74 & 0.762 & 0.021 & 0.741 \\
\hline 46.6 & 1.27 & 0.64 & 25.37 & 0.814 & 0.206 & 0.607 \\
\hline 46.8 & 1.27 & 0.58 & 20.00 & 0.733 & 0.147 & 0.586 \\
\hline 47.0 & 1.27 & 0.45 & 10.86 & 0.566 & 0.061 & 0.504 \\
\hline 47.2 & 1.27 & 0.43 & 11.35 & 0.551 & 0.063 & 0.489 \\
\hline 47.4 & 0.55 & 0.43 & 13.30 & 0.235 & 0.031 & 0.204 \\
\hline 47.6 & 0.55 & 0.41 & 5.17 & 0.228 & 0.012 & 0.217 \\
\hline 47.8 & 0.55 & 0.44 & 0.67 & 0.245 & 0.002 & 0.243 \\
\hline 48.0 & 0.55 & 0.39 & 1.11 & 0.215 & 0.002 & 0.213 \\
\hline 48.2 & 0.55 & 0.46 & 10.89 & 0.257 & 0.028 & 0.229 \\
\hline 48.4 & 0.55 & 0.47 & 12.24 & 0.259 & 0.032 & 0.227 \\
\hline 48.6 & 0.55 & 0.40 & 2.52 & 0.223 & 0.006 & 0.218 \\
\hline 48.8 & 0.55 & 0.50 & 7.24 & 0.276 & 0.020 & 0.256 \\
\hline 49.0 & 0.55 & 0.58 & 17.11 & 0.321 & 0.055 & 0.266 \\
\hline 49.2 & 0.55 & 0.63 & 34.18 & 0.351 & 0.120 & 0.231 \\
\hline 49.4 & 0.55 & 0.75 & 47.06 & 0.414 & 0.195 & 0.219 \\
\hline 49.6 & 0.55 & 0.84 & 57.24 & 0.464 & 0.265 & 0.198 \\
\hline 49.8 & 0.55 & 0.83 & 58.02 & 0.461 & 0.268 & 0.194 \\
\hline 50.0 & 0.55 & 0.78 & 46.64 & 0.432 & 0.202 & 0.231 \\
\hline 50.2 & 0.55 & 0.78 & 46.71 & 0.433 & 0.202 & 0.231 \\
\hline 50.4 & 0.55 & 0.80 & 47.09 & 0.441 & 0.208 & 0.233 \\
\hline 50.6 & 0.00 & 0.81 & 46.84 & 0.001 & 0.000 & 0.000 \\
\hline 50.8 & 0.00 & 0.83 & 46.59 & 0.001 & 0.000 & 0.000 \\
\hline 51.0 & 0.00 & 0.85 & 46.34 & 0.001 & 0.000 & 0.000 \\
\hline 51.2 & 0.00 & 0.86 & 46.09 & 0.001 & 0.000 & 0.000 \\
\hline 51.4 & 0.00 & 0.88 & 45.85 & 0.001 & 0.000 & 0.000 \\
\hline 51.6 & 0.00 & 0.90 & 45.60 & 0.001 & 0.000 & 0.000 \\
\hline 51.8 & 0.00 & 0.91 & 45.35 & 0.001 & 0.000 & 0.000 \\
\hline 52.0 & 0.00 & 0.93 & 45.10 & 0.001 & 0.000 & 0.000 \\
\hline 52.2 & 0.00 & 0.95 & 44.86 & 0.001 & 0.000 & 0.000 \\
\hline 52.4 & 0.00 & 0.96 & 44.61 & 0.001 & 0.000 & 0.000 \\
\hline 52.6 & 0.00 & 0.98 & 44.36 & 0.001 & 0.000 & 0.000 \\
\hline 52.8 & 0.00 & 1.00 & 44.11 & 0.001 & 0.000 & 0.000 \\
\hline 53.0 & 0.00 & 1.01 & 43.86 & 0.001 & 0.000 & 0.000 \\
\hline 53.2 & 0.00 & 1.03 & 43.62 & 0.001 & 0.000 & 0.001 \\
\hline 53.4 & 1.50 & 1.04 & 43.28 & 1.566 & 0.678 & 0.888 \\
\hline 53.6 & 1.50 & 1.05 & 42.48 & 1.568 & 0.666 & 0.902 \\
\hline 53.8 & 1.50 & 1.05 & 41.62 & 1.566 & 0.652 & 0.914 \\
\hline 54.0 & 1.50 & 1.04 & 40.46 & 1.565 & 0.633 & 0.932 \\
\hline 54.2 & 1.50 & 1.04 & 29.41 & 1.564 & 0.460 & 1.104 \\
\hline 54.4 & 1.50 & 1.04 & 24.31 & 1.563 & 0.380 & 1.183 \\
\hline 54.6 & 1.50 & 0.97 & 27.62 & 1.453 & 0.401 & 1.052 \\
\hline 54.8 & 1.50 & 0.72 & 36.44 & 1.074 & 0.391 & 0.683 \\
\hline 55.0 & 1.50 & 0.77 & 31.03 & 1.152 & 0.357 & 0.794 \\
\hline 55.2 & 1.50 & 0.92 & 22.93 & 1.376 & 0.315 & 1.060 \\
\hline 55.4 & 1.50 & 1.00 & 15.38 & 1.495 & 0.230 & 1.265 \\
\hline 55.6 & 1.50 & 0.94 & 13.65 & 1.416 & 0.193 & 1.222 \\
\hline 55.8 & 1.50 & 0.81 & 0.35 & 1.220 & 0.004 & 1.216 \\
\hline 56.0 & 0.31 & 0.88 & 0.36 & 0.274 & 0.001 & 0.273 \\
\hline 56.2 & 0.31 & 0.93 & 1.83 & 0.288 & 0.005 & 0.283 \\
\hline
\end{tabular}


Table T19 (continued).

\begin{tabular}{|c|c|c|c|c|c|c|}
\hline $\begin{array}{l}\text { Age } \\
(\mathrm{Ma})\end{array}$ & $\begin{array}{c}\text { LSR } \\
(\mathrm{cm} / \mathrm{k} . y .)\end{array}$ & $\begin{array}{l}\text { Dry density } \\
\left(\mathrm{g} / \mathrm{cm}^{3}\right)\end{array}$ & $\begin{array}{c}\mathrm{CaCO}_{3} \\
(\mathrm{wt} \%)\end{array}$ & $\begin{array}{c}\text { MAR } \\
\left(\mathrm{cm} / \mathrm{m}^{2} / \mathrm{k} . \mathrm{y} .\right)\end{array}$ & $\begin{array}{c}\text { CAR } \\
\left(\mathrm{cm} / \mathrm{m}^{2} / \mathrm{k} . y .\right)\end{array}$ & $\begin{array}{c}\text { nCAR } \\
\left(\mathrm{cm} / \mathrm{m}^{2} / \mathrm{k} . y .\right)\end{array}$ \\
\hline 56.4 & 0.31 & 0.90 & 2.58 & 0.280 & 0.007 & 0.273 \\
\hline 56.6 & 0.31 & 0.89 & 2.38 & 0.276 & 0.007 & 0.269 \\
\hline 56.8 & 0.31 & 0.88 & 2.18 & 0.273 & 0.006 & 0.267 \\
\hline 57.0 & 0.31 & 0.87 & 1.98 & 0.270 & 0.005 & 0.265 \\
\hline 57.2 & 0.31 & 0.86 & 1.78 & 0.267 & 0.005 & 0.262 \\
\hline 57.4 & 0.31 & 0.85 & 1.58 & 0.264 & 0.004 & 0.260 \\
\hline 57.6 & 0.31 & 0.84 & 1.37 & 0.261 & 0.004 & 0.257 \\
\hline 57.8 & 0.31 & 0.83 & 1.17 & 0.257 & 0.003 & 0.254 \\
\hline 58.0 & 0.31 & 0.82 & 0.97 & 0.254 & 0.002 & 0.252 \\
\hline 58.2 & 0.31 & 0.81 & 0.77 & 0.251 & 0.002 & 0.249 \\
\hline 58.4 & 0.31 & 0.80 & 0.57 & 0.248 & 0.001 & 0.247 \\
\hline 58.6 & 0.31 & 0.79 & 0.38 & 0.245 & 0.001 & 0.244 \\
\hline 58.8 & 0.31 & 0.78 & 0.26 & 0.242 & 0.001 & 0.241 \\
\hline 59.0 & 0.31 & 0.78 & 0.18 & 0.242 & 0.000 & 0.241 \\
\hline 59.2 & 0.31 & 0.79 & 0.14 & 0.246 & 0.000 & 0.245 \\
\hline 59.4 & 0.31 & 0.81 & 0.20 & 0.251 & 0.000 & 0.250 \\
\hline 59.6 & 0.31 & 0.83 & 0.28 & 0.256 & 0.001 & 0.255 \\
\hline 59.8 & 0.31 & 0.84 & 0.47 & 0.262 & 0.001 & 0.261 \\
\hline 60.0 & 0.31 & 0.87 & 0.60 & 0.269 & 0.002 & 0.268 \\
\hline 60.2 & 0.31 & 0.92 & 0.59 & 0.284 & 0.002 & 0.283 \\
\hline 60.4 & 0.31 & 0.97 & 2.85 & 0.301 & 0.009 & 0.292 \\
\hline 60.6 & 0.31 & 1.02 & 14.91 & 0.315 & 0.047 & 0.268 \\
\hline 60.8 & 0.31 & 1.06 & 11.80 & 0.329 & 0.039 & 0.290 \\
\hline 61.0 & 0.31 & 1.10 & 24.13 & 0.341 & 0.082 & 0.259 \\
\hline 61.2 & 0.31 & 1.10 & 37.13 & 0.341 & 0.127 & 0.215 \\
\hline 61.4 & 0.31 & 1.09 & 37.21 & 0.339 & 0.126 & 0.213 \\
\hline 61.6 & 0.31 & 1.09 & 36.14 & 0.337 & 0.122 & 0.215 \\
\hline 61.8 & 0.31 & 1.08 & 34.68 & 0.336 & 0.116 & 0.219 \\
\hline 62.0 & 0.31 & 1.08 & 33.22 & 0.334 & 0.111 & 0.223 \\
\hline 62.2 & 0.31 & 1.07 & 31.77 & 0.332 & 0.105 & 0.226 \\
\hline 62.4 & 0.31 & 1.06 & 30.31 & 0.330 & 0.100 & 0.230 \\
\hline 62.6 & 0.31 & 1.06 & 28.85 & 0.328 & 0.095 & 0.233 \\
\hline 62.8 & 0.31 & 1.05 & 27.39 & 0.326 & 0.089 & 0.237 \\
\hline 63.0 & 0.31 & 1.04 & 25.93 & 0.324 & 0.084 & 0.240 \\
\hline 63.2 & 0.31 & 1.04 & 24.47 & 0.322 & 0.079 & 0.243 \\
\hline 63.4 & 0.31 & 1.03 & 23.01 & 0.320 & 0.074 & 0.246 \\
\hline 63.6 & 0.31 & 1.03 & 21.93 & 0.321 & 0.070 & 0.250 \\
\hline 63.8 & 0.31 & 1.08 & 23.63 & 0.336 & 0.079 & 0.256 \\
\hline 64.0 & 0.31 & 1.13 & 24.39 & 0.349 & 0.085 & 0.264 \\
\hline 64.2 & 0.31 & 1.10 & 17.74 & 0.340 & 0.060 & 0.280 \\
\hline 64.4 & 0.31 & 1.06 & 10.10 & 0.327 & 0.033 & 0.294 \\
\hline 64.6 & 0.31 & 1.01 & 3.13 & 0.314 & 0.010 & 0.305 \\
\hline 64.8 & 0.31 & 1.03 & 11.01 & 0.318 & 0.035 & 0.283 \\
\hline 65.0 & 0.31 & 1.07 & 19.55 & 0.333 & 0.065 & 0.268 \\
\hline 65.2 & 0.31 & 1.03 & 5.90 & 0.321 & 0.019 & 0.302 \\
\hline 65.4 & 0.31 & 1.04 & 16.30 & 0.321 & 0.052 & 0.269 \\
\hline 65.6 & 0.31 & 1.13 & 32.14 & 0.351 & 0.113 & 0.238 \\
\hline 65.8 & 0.31 & 1.14 & 31.81 & 0.355 & 0.113 & 0.242 \\
\hline 66.0 & 0.31 & 1.12 & 57.45 & 0.348 & 0.200 & 0.148 \\
\hline 66.2 & 0.31 & 1.09 & 68.04 & 0.338 & 0.230 & 0.108 \\
\hline 66.4 & 0.31 & 1.06 & 63.32 & 0.330 & 0.209 & 0.121 \\
\hline 66.6 & 0.31 & 1.12 & 51.16 & 0.347 & 0.177 & 0.169 \\
\hline 66.8 & 0.31 & 1.18 & 59.48 & 0.367 & 0.218 & 0.149 \\
\hline 67.0 & 0.31 & 1.24 & 54.66 & 0.385 & 0.211 & 0.175 \\
\hline 67.2 & 0.31 & 1.26 & 43.15 & 0.391 & 0.169 & 0.222 \\
\hline 67.4 & 0.31 & 1.27 & 59.74 & 0.393 & 0.235 & 0.158 \\
\hline 67.6 & 0.31 & 1.27 & 63.66 & 0.393 & 0.250 & 0.143 \\
\hline 67.8 & 0.31 & 1.25 & 66.77 & 0.389 & 0.260 & 0.129 \\
\hline 68.0 & 1.08 & 1.20 & 70.35 & 1.290 & 0.907 & 0.382 \\
\hline 68.2 & 1.08 & 1.19 & 74.86 & 1.276 & 0.955 & 0.321 \\
\hline 68.4 & 1.08 & 1.20 & 70.73 & 1.289 & 0.912 & 0.377 \\
\hline 68.6 & 1.08 & 1.29 & 67.21 & 1.388 & 0.933 & 0.455 \\
\hline 68.8 & 1.08 & 1.44 & 79.78 & 1.554 & 1.240 & 0.314 \\
\hline 69.0 & 1.08 & 1.38 & 82.72 & 1.482 & 1.225 & 0.256 \\
\hline 69.2 & 1.08 & 1.23 & 78.12 & 1.327 & 1.037 & 0.290 \\
\hline 69.4 & 1.08 & 1.19 & 72.99 & 1.279 & 0.934 & 0.345 \\
\hline
\end{tabular}

$\mathrm{LSR}=$ linear sedimentation rate, $\mathrm{MAR}=$ mass accumulation rate, $\mathrm{CAR}=$ carbonate accumulation rate, $\mathrm{nCAR}=$ noncarbonate accumulation rate 
Table T20. Geochemistry of headspace gas samples, Hole U1403A.

\begin{tabular}{|c|c|c|}
\hline $\begin{array}{l}\text { Core, section, } \\
\text { interval }(\mathrm{cm})\end{array}$ & $\begin{array}{l}\text { Depth } \\
\text { (mbsf) }\end{array}$ & $\begin{array}{c}\text { Methane } \\
(p p m v)\end{array}$ \\
\hline \multicolumn{3}{|l|}{ 342-U1403A- } \\
\hline $1 \mathrm{H}-4,0-5$ & 4.50 & 2.93 \\
\hline $2 \mathrm{H}-7,0-5$ & 14.80 & 2.12 \\
\hline $3 \mathrm{H}-7,0-5$ & 24.30 & 2.07 \\
\hline $4 \mathrm{H}-7,0-5$ & 33.50 & 2.01 \\
\hline $5 \mathrm{H}-7,0-5$ & 43.10 & 2.66 \\
\hline $6 \mathrm{H}-7,0-5$ & 52.88 & 3.89 \\
\hline $7 \mathrm{H}-7,0-5$ & 62.30 & 3.72 \\
\hline $8 \mathrm{H}-7,0-5$ & 71.83 & 4.72 \\
\hline $9 \mathrm{H}-7,0-5$ & 81.00 & 6.70 \\
\hline $10 \mathrm{H}-7,0-5$ & 90.71 & 6.73 \\
\hline $11 \mathrm{H}-7,0-5$ & 100.30 & 6.57 \\
\hline $12 \mathrm{H}-5,0-5$ & 106.81 & 6.69 \\
\hline $13 \mathrm{H}-5,142-147$ & 117.63 & 7.21 \\
\hline $14 \mathrm{H}-7,0-5$ & 128.64 & 10.99 \\
\hline $15 \mathrm{H}-6,0-5$ & 136.80 & 9.99 \\
\hline $16 \mathrm{H}-6,0-5$ & 146.05 & 9.41 \\
\hline $19 X-7,0-5$ & 164.80 & 12.73 \\
\hline $20 x-7,0-5$ & 174.60 & 10.15 \\
\hline $21 X-7,0-5$ & 183.90 & 8.03 \\
\hline $22 X-3,0-5$ & 187.60 & 6.85 \\
\hline $23 X-7,0-5$ & 203.50 & 7.80 \\
\hline $25 X-5,0-5$ & 215.70 & 16.19 \\
\hline $26 X-7,0-5$ & 223.26 & 12.64 \\
\hline $27 X-6,0-5$ & 231.70 & 9.90 \\
\hline $28 X-6,0-5$ & 241.40 & 7.95 \\
\hline
\end{tabular}


Table T21. Interstitial water constituents, Hole U1403A.

\begin{tabular}{|c|c|c|c|c|c|c|c|c|c|c|c|c|c|c|c|c|}
\hline $\begin{array}{l}\text { Core, section, } \\
\text { interval }(\mathrm{cm})\end{array}$ & $\begin{array}{l}\text { Depth } \\
\text { (mbsf) }\end{array}$ & $\mathrm{pH}$ & $\begin{array}{l}\text { Alkalinity } \\
(\mathrm{mM})\end{array}$ & $\begin{array}{c}\text { Ammonium } \\
(\mu \mathrm{M})\end{array}$ & Salinity & $\begin{array}{c}\mathrm{Cl}^{-} \\
(\mathrm{mM})^{*}\end{array}$ & $\begin{array}{c}\mathrm{Cl}^{-} \\
(\mathrm{mM})^{\dagger}\end{array}$ & $\begin{array}{l}\mathrm{Na}^{+} \\
(\mathrm{mM})\end{array}$ & $\begin{array}{l}\mathrm{SO}_{4}^{2-} \\
(\mathrm{mM})\end{array}$ & $\begin{array}{l}\mathrm{HPO}_{4}^{-} \\
(\mu \mathrm{M})\end{array}$ & $\begin{array}{l}\mathrm{Mn}^{2+} \\
(\mu \mathrm{M})\end{array}$ & $\begin{array}{l}\mathrm{Fe}^{2+} \\
(\mu \mathrm{M})\end{array}$ & $\begin{array}{l}\mathrm{Ca}^{2+} \\
(\mathrm{mM})\end{array}$ & $\begin{array}{l}\mathrm{Mg}^{2+} \\
(\mathrm{mM})\end{array}$ & $\begin{array}{l}\mathrm{Sr}^{2+} \\
(\mu \mathrm{M})\end{array}$ & $\begin{array}{c}\mathrm{K}^{+} \\
(\mathrm{mM})\end{array}$ \\
\hline \multicolumn{17}{|l|}{ 342-U1403A- } \\
\hline $2 \mathrm{H}-6,145-150$ & 14.75 & 7.39 & 2.93 & 7 & 36 & 560 & 571 & 518 & 31.5 & BDL & BDL & 1.2 & 12.6 & 56.6 & 78.5 & 12.3 \\
\hline $3 \mathrm{H}-6,145-150$ & 24.25 & 7.29 & 2.96 & 5 & 37 & 540 & 574 & 529 & 35.6 & BDL & BDL & 0.2 & 13.8 & 58.7 & 86.7 & 12.3 \\
\hline $4 \mathrm{H}-6,115-120$ & 33.45 & 7.39 & 3.10 & 0 & 37 & 551 & 596 & 530 & 35.3 & BDL & 17.1 & 1.0 & 14.7 & 56.8 & 88.0 & 11.8 \\
\hline $5 \mathrm{H}-6,125-130$ & 43.05 & 7.25 & 3.21 & 18 & 37 & 569 & 598 & 519 & 30.6 & BDL & 44.9 & 1.5 & 16.1 & 56.2 & 92.5 & 10.3 \\
\hline $6 \mathrm{H}-6,145-150$ & 52.83 & ND & ND & ND & ND & ND & 577 & 521 & 32.0 & BDL & 68.0 & $\mathrm{BDL}$ & 17.6 & 54.9 & 98.2 & 12.9 \\
\hline $7 \mathrm{H}-6,145-150$ & 62.25 & 7.14 & 3.22 & 16 & 36 & 537 & 598 & 511 & 29.0 & BDL & 81.2 & 0.4 & 19.3 & 56.9 & 108.4 & 10.0 \\
\hline $8 \mathrm{H}-6,145-150$ & 71.78 & 7.02 & 5.39 & 56 & 36 & 546 & 570 & 493 & 30.2 & BDL & 102.8 & 0.0 & 20.8 & 55.3 & 115.7 & 9.8 \\
\hline $9 \mathrm{H}-6,120-130$ & 80.90 & 7.05 & 2.69 & 73 & 37 & 556 & 591 & 523 & 27.9 & BDL & 115.3 & $\mathrm{BDL}$ & 20.9 & 53.0 & 121.6 & 9.7 \\
\hline $10 \mathrm{H}-6,140-150$ & 90.61 & ND & ND & 38 & 37 & ND & 584 & 519 & 28.4 & BDL & 124.2 & $\mathrm{BDL}$ & 21.9 & 52.1 & 130.2 & 9.2 \\
\hline $11 \mathrm{H}-6,140-150$ & 100.20 & 7.18 & 4.37 & 34 & 37 & 560 & 604 & 530 & 28.3 & BDL & 126.9 & $\mathrm{BDL}$ & 26.3 & 54.4 & 138.2 & 11.4 \\
\hline $13 \mathrm{H}-6,136-146$ & 119.04 & 7.25 & 4.57 & 68 & 38 & 562 & 591 & 509 & 31.0 & BDL & 108.1 & $\mathrm{BDL}$ & 28.5 & 51.1 & 144.4 & 7.8 \\
\hline $14 \mathrm{H}-6,136-146$ & 128.54 & 7.19 & 4.31 & 56 & 38 & 570 & 598 & 522 & 26.3 & BDL & 109.3 & 0.1 & 29.5 & 49.4 & 147.6 & 9.3 \\
\hline $15 \mathrm{H}-5,140-150$ & 136.70 & 7.02 & 4.46 & 51 & 38 & 570 & 585 & 515 & 30.6 & $\mathrm{BDL}$ & 127.6 & $\mathrm{BDL}$ & 29.7 & 48.5 & 145.5 & 10.2 \\
\hline $19 X-6,120-130$ & 164.70 & 7.24 & 3.54 & 70 & 37 & ND & 602 & 498 & 23.5 & BDL & 155.8 & 0.3 & 38.6 & 46.2 & 177.9 & 9.8 \\
\hline $20 X-6,130-140$ & 174.50 & 6.98 & 3.64 & 132 & 37 & ND & 581 & 477 & 26.8 & BDL & 163.7 & $\mathrm{BDL}$ & 39.7 & 46.0 & 183.7 & 6.5 \\
\hline $23 X-6,130-140$ & 203.40 & 7.24 & 3.47 & 79 & 37 & 575 & 586 & 469 & 19.3 & BDL & 183.8 & 1.3 & 42.8 & 39.5 & 197.9 & 8.0 \\
\hline $27 X-5,140-150$ & 231.60 & 7.19 & 3.07 & 72 & 38 & 572 & 592 & 477 & 19.6 & BDL & 196.5 & 0.5 & 47.8 & 37.0 & 203.5 & 6.3 \\
\hline $28 X-5,140-150$ & 241.30 & 7.10 & 2.98 & 138 & 38 & 583 & 597 & 480 & 20.5 & BDL & 196.3 & 1.5 & 46.3 & 37.2 & 209.4 & 6.3 \\
\hline
\end{tabular}

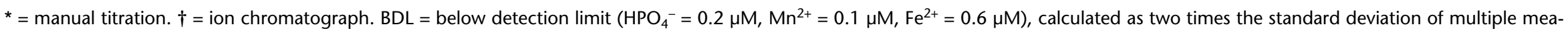
sures of a blank. ND = not detected. 
Table T22. Sedimentary sample and bulk elemental geochemistry, Hole U1403A. (Continued on next four pages.)

\begin{tabular}{|c|c|c|c|c|c|c|c|c|c|c|}
\hline $\begin{array}{l}\text { Core, section, } \\
\text { interval }(\mathrm{cm})\end{array}$ & $\begin{array}{l}\text { Depth } \\
\text { (mbsf) }\end{array}$ & $\begin{array}{l}\mathrm{CaCO}_{3} \\
\text { (wt\%) }\end{array}$ & $\begin{array}{c}\text { IC } \\
\text { (wt\%) }\end{array}$ & $\begin{array}{c}\text { TC } \\
\text { (wt\%) }\end{array}$ & $\begin{array}{c}\text { TN } \\
\text { (wt\%) }\end{array}$ & $\begin{array}{c}\text { TS } \\
\text { (wt\%) }\end{array}$ & $\begin{array}{l}\text { TOC } \\
\text { (wt\%) }\end{array}$ & $\begin{array}{c}\text { Corrected } \\
\text { TC } \\
\text { (wt\%) }\end{array}$ & $\begin{array}{c}\text { Corrected } \\
\text { TOC } \\
\text { (wt\%) }\end{array}$ & $\begin{array}{c}\mathrm{TN}^{\dagger} \\
\text { (wt\%) }\end{array}$ \\
\hline \multicolumn{11}{|l|}{ 342-U1403A- } \\
\hline $1 \mathrm{H}-1,38-39$ & 0.38 & 34.56 & 4.14 & 12.86 & 0.08 & ND & 8.72 & 5.50 & 1.35 & 0.08 \\
\hline $1 \mathrm{H}-2,38-39$ & 1.88 & 25.23 & 3.03 & 9.13 & 0.03 & ND & 6.10 & 4.34 & 1.32 & 0.03 \\
\hline $1 \mathrm{H}-3,42-43$ & 3.42 & 0.46 & 0.06 & 0.43 & 0.08 & ND & 0.37 & 0.43 & 0.38 & 0.08 \\
\hline $1 \mathrm{H}-4,38-39$ & 4.88 & 0.42 & 0.05 & 0.41 & 0.08 & ND & 0.36 & 0.41 & 0.36 & 0.08 \\
\hline $2 \mathrm{H}-1,35-36$ & 6.15 & 0.43 & 0.05 & 0.39 & 0.09 & ND & 0.34 & 0.39 & 0.34 & 0.09 \\
\hline $2 \mathrm{H}-2,23-24$ & 7.53 & 0.17 & 0.02 & 0.26 & 0.10 & ND & 0.24 & 0.26 & 0.24 & 0.10 \\
\hline $2 \mathrm{H}-3,35-36$ & 9.15 & 0.34 & 0.04 & 0.18 & 0.08 & ND & 0.14 & 0.18 & 0.14 & 0.08 \\
\hline $2 \mathrm{H}-4,35-36$ & 10.65 & 0.28 & 0.03 & 0.21 & 0.09 & ND & 0.18 & 0.21 & 0.18 & 0.09 \\
\hline $2 \mathrm{H}-5,35-36$ & 12.15 & 0.29 & 0.04 & 0.20 & 0.10 & ND & 0.17 & 0.20 & 0.17 & 0.10 \\
\hline $2 \mathrm{H}-6,35-36$ & 13.65 & 0.40 & 0.05 & 0.22 & 0.09 & ND & 0.17 & 0.22 & 0.17 & 0.09 \\
\hline $2 \mathrm{H}-7,12-13$ & 14.92 & 0.35 & 0.04 & 0.42 & 0.11 & ND & 0.38 & 0.42 & 0.38 & 0.11 \\
\hline $3 \mathrm{H}-2,34-35$ & 17.14 & 0.31 & 0.04 & 0.45 & 0.12 & ND & 0.41 & 0.45 & 0.41 & 0.12 \\
\hline $3 \mathrm{H}-3,34-35$ & 18.64 & 0.07 & 0.01 & 0.35 & 0.12 & ND & 0.34 & 0.35 & 0.34 & 0.12 \\
\hline $3 \mathrm{H}-4,34-35$ & 20.14 & 0.31 & 0.04 & 0.30 & 0.09 & ND & 0.26 & 0.30 & 0.26 & 0.09 \\
\hline $3 \mathrm{H}-5,34-35$ & 21.64 & 0.38 & 0.05 & 0.25 & 0.07 & ND & 0.21 & 0.25 & 0.21 & 0.07 \\
\hline $3 \mathrm{H}-6,32-33$ & 23.12 & 0.27 & 0.03 & 0.22 & 0.07 & ND & 0.19 & 0.22 & 0.19 & 0.07 \\
\hline $3 \mathrm{H}-7,28-29$ & 24.58 & 0.27 & 0.03 & 0.33 & 0.08 & ND & 0.30 & 0.33 & 0.30 & 0.08 \\
\hline $4 \mathrm{H}-1,35-36$ & 25.15 & 0.22 & 0.03 & 0.36 & 0.10 & ND & 0.33 & 0.36 & 0.33 & 0.10 \\
\hline $4 \mathrm{H}-2,35-36$ & 26.65 & 0.38 & 0.05 & 1.40 & 0.17 & ND & 1.35 & 1.40 & 1.35 & 0.17 \\
\hline $4 \mathrm{H}-2,35-36$ & 26.65 & 0.38 & 0.05 & 1.63 & 0.69 & 0.00 & 1.58 & 1.63 & 1.58 & \\
\hline $4 \mathrm{H}-3,35-36$ & 28.15 & 0.29 & 0.04 & 1.43 & 0.18 & ND & 1.39 & 1.43 & 1.40 & 0.18 \\
\hline $4 \mathrm{H}-4,35-36$ & 29.65 & 0.08 & 0.01 & 1.69 & 0.18 & ND & 1.68 & 1.69 & 1.68 & 0.18 \\
\hline $4 \mathrm{H}-5,35-36$ & 31.15 & 0.42 & 0.05 & 1.55 & 0.17 & ND & 1.50 & 1.55 & 1.50 & 0.17 \\
\hline $4 \mathrm{H}-6,22-23$ & 32.52 & 0.36 & 0.04 & 0.50 & 0.10 & ND & 0.46 & 0.50 & 0.46 & 0.10 \\
\hline $4 \mathrm{H}-7,13-14$ & 33.63 & 0.36 & 0.04 & 0.38 & 0.09 & ND & 0.34 & 0.38 & 0.34 & 0.09 \\
\hline $5 \mathrm{H}-1,49-50$ & 34.79 & 0.25 & 0.03 & 0.52 & 0.12 & 0.47 & 0.49 & 0.52 & 0.49 & 0.12 \\
\hline $5 \mathrm{H}-2,41-42$ & 36.21 & 0.40 & 0.05 & 0.36 & 0.11 & 0.47 & 0.31 & 0.36 & 0.31 & 0.11 \\
\hline $5 \mathrm{H}-3,41-42$ & 37.71 & 0.38 & 0.05 & 0.54 & 0.13 & 0.43 & 0.49 & 0.54 & 0.50 & 0.13 \\
\hline $5 \mathrm{H}-3,41-42$ & 37.71 & 0.38 & 0.05 & 0.62 & 0.54 & 0.00 & 0.58 & 0.62 & 0.58 & \\
\hline $5 \mathrm{H}-4,41-42$ & 39.21 & 0.07 & 0.01 & 0.49 & 0.13 & 0.41 & 0.48 & 0.49 & 0.48 & 0.13 \\
\hline $5 \mathrm{H}-5,41-42$ & 40.71 & 0.06 & 0.01 & 0.29 & 0.11 & 0.28 & 0.28 & 0.29 & 0.28 & 0.11 \\
\hline $5 \mathrm{H}-6,41-42$ & 42.21 & 0.31 & 0.04 & 0.28 & 2.52 & 0.42 & 0.24 & 0.28 & 0.24 & \\
\hline $5 \mathrm{H}-6,41-42^{*}$ & 42.21 & 0.31 & 0.04 & 0.10 & 10.41 & & 0.06 & 0.29 & 0.25 & \\
\hline $5 \mathrm{H}-7,12-13$ & 43.22 & 0.18 & 0.02 & 0.28 & 0.11 & 0.44 & 0.26 & 0.28 & 0.26 & 0.11 \\
\hline $6 \mathrm{H}-1,41-42$ & 44.21 & 0.36 & 0.04 & 0.26 & 0.11 & 0.52 & 0.22 & 0.26 & 0.22 & 0.11 \\
\hline $6 \mathrm{H}-2,41-42$ & 45.71 & 0.41 & 0.05 & 0.16 & 0.09 & 0.42 & 0.11 & 0.16 & 0.11 & 0.09 \\
\hline $6 \mathrm{H}-3,41-42$ & 47.23 & 0.06 & 0.01 & 0.11 & 0.09 & 0.47 & 0.10 & 0.11 & 0.10 & 0.09 \\
\hline $6 \mathrm{H}-4,41-42$ & 48.75 & 0.39 & 0.05 & 0.11 & 0.10 & 0.42 & 0.06 & 0.11 & 0.06 & 0.10 \\
\hline $6 \mathrm{H}-5,41-42$ & 50.27 & 0.36 & 0.04 & 0.10 & 0.11 & 0.28 & 0.06 & 0.10 & 0.06 & 0.11 \\
\hline $6 \mathrm{H}-6,41-42$ & 51.79 & 0.21 & 0.03 & 0.11 & 0.11 & 0.47 & 0.09 & 0.11 & 0.09 & 0.11 \\
\hline $6 \mathrm{H}-7,17-18$ & 53.05 & 0.36 & 0.04 & 0.12 & 0.11 & 0.38 & 0.08 & 0.12 & 0.08 & 0.11 \\
\hline 7H-1, 38-39 & 53.68 & 0.04 & 0.01 & 0.11 & 0.12 & 0.47 & 0.10 & 0.11 & 0.11 & 0.12 \\
\hline $7 \mathrm{H}-2,38-39$ & 55.18 & 0.05 & 0.01 & 0.10 & 0.10 & 0.52 & 0.09 & 0.10 & 0.09 & 0.10 \\
\hline $7 \mathrm{H}-3,38-39$ & 56.68 & 0.07 & 0.01 & 0.11 & 0.10 & 0.46 & 0.10 & 0.11 & 0.10 & 0.10 \\
\hline $7 \mathrm{H}-4,38-39$ & 58.18 & 0.38 & 0.05 & 0.12 & 0.09 & 0.43 & 0.07 & 0.12 & 0.08 & 0.09 \\
\hline $7 \mathrm{H}-5,38-39$ & 59.68 & 0.40 & 0.05 & 0.11 & 0.10 & 0.45 & 0.06 & 0.11 & 0.06 & 0.10 \\
\hline $7 \mathrm{H}-6,38-39$ & 61.18 & 0.37 & 0.05 & 0.13 & 0.10 & 0.45 & 0.09 & 0.13 & 0.09 & 0.10 \\
\hline $7 \mathrm{H}-7,14-15$ & 62.44 & 0.05 & 0.01 & 0.12 & 0.09 & 0.40 & 0.11 & 0.12 & 0.11 & 0.09 \\
\hline $8 \mathrm{H}-1,28-29$ & 63.08 & 0.08 & 0.01 & 0.09 & 2.69 & 0.46 & 0.08 & 0.09 & 0.08 & \\
\hline $8 \mathrm{H}-2,38-39$ & 64.68 & 0.30 & 0.04 & 0.20 & 3.05 & 0.45 & 0.16 & 0.20 & 0.16 & \\
\hline $8 \mathrm{H}-2,38-39$ & 64.68 & 0.30 & 0.04 & 0.13 & 0.58 & 0.00 & 0.09 & 0.13 & 0.09 & \\
\hline $8 \mathrm{H}-3,38-39$ & 66.18 & 0.37 & 0.04 & 0.12 & 0.10 & 0.58 & 0.08 & 0.12 & 0.08 & 0.10 \\
\hline $8 \mathrm{H}-4,38-39$ & 67.68 & 0.35 & 0.04 & 0.15 & 1.95 & 0.38 & 0.11 & 0.15 & 0.11 & \\
\hline $8 \mathrm{H}-5,38-39$ & 69.21 & 0.32 & 0.04 & 0.17 & 2.35 & 0.41 & 0.13 & 0.17 & 0.13 & \\
\hline $8 \mathrm{H}-5,38-39^{*}$ & 69.21 & 0.32 & 0.04 & 0.09 & 11.32 & & 0.05 & 0.26 & 0.22 & \\
\hline $8 \mathrm{H}-6,38-39$ & 70.71 & 0.37 & 0.05 & 0.14 & 0.09 & 0.28 & 0.10 & 0.14 & 0.10 & 0.09 \\
\hline $8 \mathrm{H}-7,18-19$ & 72.01 & 0.33 & 0.04 & 0.14 & 0.11 & 0.46 & 0.10 & 0.14 & 0.10 & 0.11 \\
\hline $9 \mathrm{H}-1,38-39$ & 72.68 & 0.36 & 0.04 & 0.11 & 3.71 & 0.44 & 0.07 & 0.11 & 0.07 & \\
\hline $9 \mathrm{H}-2,38-39$ & 74.18 & 0.49 & 0.06 & 0.17 & 2.49 & 0.44 & 0.11 & 0.17 & 0.11 & \\
\hline $9 \mathrm{H}-3,38-39$ & 75.68 & 0.37 & 0.04 & 0.16 & 2.93 & 0.42 & 0.12 & 0.16 & 0.12 & \\
\hline $9 \mathrm{H}-4,38-39$ & 77.15 & 0.40 & 0.05 & 0.16 & 2.29 & 0.50 & 0.11 & 0.16 & 0.11 & \\
\hline $9 \mathrm{H}-5,38-39$ & 78.62 & 0.38 & 0.05 & 0.11 & 1.41 & 0.48 & 0.07 & 0.11 & 0.07 & \\
\hline $9 \mathrm{H}-6,38-39$ & 80.08 & 0.17 & 0.02 & 0.17 & 2.70 & 0.44 & 0.15 & 0.17 & 0.15 & \\
\hline $9 \mathrm{H}-7,14-15$ & 81.14 & 0.14 & 0.02 & 0.11 & 4.37 & 0.00 & 0.09 & 0.11 & 0.09 & \\
\hline $10 \mathrm{H}-1,38-39$ & 82.18 & 0.38 & 0.05 & 0.11 & 4.39 & 0.47 & 0.06 & 0.11 & 0.06 & \\
\hline
\end{tabular}


Table T22 (continued). (Continued on next page.)

\begin{tabular}{|c|c|c|c|c|c|c|c|c|c|c|}
\hline $\begin{array}{l}\text { Core, section, } \\
\text { interval }(\mathrm{cm})\end{array}$ & $\begin{array}{l}\text { Depth } \\
\text { (mbsf) }\end{array}$ & $\begin{array}{c}\mathrm{CaCO}_{3} \\
\text { (wt\%) }\end{array}$ & $\begin{array}{c}\text { IC } \\
\text { (wt\%) }\end{array}$ & $\begin{array}{c}\text { TC } \\
\text { (wt\%) }\end{array}$ & $\begin{array}{c}\text { TN } \\
\text { (wt\%) }\end{array}$ & $\begin{array}{c}\text { TS } \\
\text { (wt\%) }\end{array}$ & $\begin{array}{c}\text { TOC } \\
\text { (wt\%) }\end{array}$ & $\begin{array}{c}\text { Corrected } \\
\text { TC } \\
\text { (wt\%) }\end{array}$ & $\begin{array}{c}\text { Corrected } \\
\text { TOC } \\
(w t \%)\end{array}$ & $\begin{array}{c}\mathrm{TN}^{\dagger} \\
\text { (wt\%) }\end{array}$ \\
\hline $10 \mathrm{H}-2,38-39$ & 83.69 & 0.36 & 0.04 & 0.12 & 3.37 & 0.44 & 0.08 & 0.12 & 0.08 & \\
\hline $10 \mathrm{H}-3,38-39$ & 85.20 & 0.39 & 0.05 & 0.17 & 2.62 & 0.47 & 0.12 & 0.17 & 0.12 & \\
\hline $10 \mathrm{H}-4,38-39$ & 86.66 & 0.34 & 0.04 & 0.16 & 2.04 & 0.45 & 0.12 & 0.16 & 0.12 & \\
\hline $10 \mathrm{H}-5,38-39$ & 88.13 & 0.39 & 0.05 & 0.16 & 1.45 & 0.47 & 0.11 & 0.16 & 0.11 & \\
\hline $10 \mathrm{H}-6,38-39$ & 89.59 & 0.45 & 0.05 & 0.24 & 3.04 & 0.45 & 0.19 & 0.24 & 0.19 & \\
\hline $10 \mathrm{H}-7,20-21$ & 90.91 & 0.38 & 0.05 & 0.17 & 1.97 & 0.47 & 0.12 & 0.17 & 0.12 & \\
\hline $11 \mathrm{H}-1,38-39$ & 91.68 & 0.42 & 0.05 & 0.17 & 2.36 & 0.48 & 0.12 & 0.17 & 0.12 & \\
\hline $11 \mathrm{H}-2,38-39$ & 93.18 & 0.19 & 0.02 & 0.13 & 3.92 & 0.41 & 0.11 & 0.13 & 0.11 & \\
\hline $11 \mathrm{H}-2,38-39$ & 93.18 & 0.19 & 0.02 & 0.18 & 1.19 & 0.25 & 0.16 & 0.18 & 0.16 & \\
\hline $11 \mathrm{H}-3,38-39$ & 94.68 & 0.37 & 0.04 & 0.19 & 2.06 & 0.41 & 0.15 & 0.19 & 0.15 & \\
\hline $11 \mathrm{H}-4,38-39$ & 96.18 & 0.35 & 0.04 & 0.19 & 2.32 & 0.30 & 0.15 & 0.19 & 0.15 & \\
\hline $11 \mathrm{H}-5,38-39$ & 97.68 & 0.41 & 0.05 & 0.23 & 3.03 & 0.45 & 0.18 & 0.23 & 0.18 & \\
\hline $11 \mathrm{H}-6,38-39$ & 99.18 & 0.33 & 0.04 & 0.35 & 2.12 & 0.44 & 0.31 & 0.35 & 0.31 & \\
\hline $11 \mathrm{H}-7,14-15$ & 100.44 & 0.29 & 0.03 & 0.21 & 1.83 & 0.42 & 0.18 & 0.21 & 0.18 & \\
\hline $12 \mathrm{H}-1,32-33$ & 101.12 & 1.24 & 0.15 & 0.68 & 0.11 & & 0.53 & 0.68 & 0.53 & 0.11 \\
\hline $12 \mathrm{H}-2,38-39$ & 102.68 & 0.36 & 0.04 & 0.28 & 3.37 & 0.44 & 0.24 & 0.28 & 0.24 & \\
\hline $12 \mathrm{H}-3,38-39$ & 104.18 & 0.80 & 0.10 & 0.49 & 4.26 & 0.43 & 0.39 & 0.49 & 0.40 & \\
\hline $12 \mathrm{H}-4,38-39$ & 105.69 & 0.34 & 0.04 & 0.31 & 3.17 & 0.39 & 0.27 & 0.31 & 0.27 & \\
\hline $12 \mathrm{H}-5,38-39$ & 107.19 & 0.41 & 0.05 & 0.33 & 2.54 & 0.28 & 0.28 & 0.33 & 0.28 & \\
\hline $12 \mathrm{H}-6,38-39$ & 108.70 & 0.77 & 0.09 & 0.49 & 3.58 & 0.42 & 0.40 & 0.49 & 0.40 & \\
\hline $12 \mathrm{H}-7,18-19$ & 110.00 & 0.17 & 0.02 & 0.41 & 1.09 & & 0.39 & 0.41 & 0.39 & \\
\hline $13 \mathrm{H}-1,38-39$ & 110.68 & 3.52 & 0.42 & 0.36 & 0.93 & & -0.06 & 0.36 & -0.06 & \\
\hline $13 \mathrm{H}-2,38-39$ & 112.18 & 0.47 & 0.06 & 0.33 & 2.54 & 0.36 & 0.27 & 0.33 & 0.27 & \\
\hline $13 \mathrm{H}-3,38-39$ & 113.65 & 0.43 & 0.05 & 0.24 & 0.07 & & 0.19 & 0.24 & 0.19 & 0.07 \\
\hline $13 \mathrm{H}-4,38-39$ & 115.12 & 0.43 & 0.05 & 0.23 & 0.06 & & 0.18 & 0.23 & 0.18 & 0.06 \\
\hline $13 \mathrm{H}-5,38-39$ & 116.59 & 0.37 & 0.05 & 0.39 & 2.55 & 0.29 & 0.35 & 0.39 & 0.35 & \\
\hline $13 \mathrm{H}-6,38-39$ & 118.06 & 0.57 & 0.07 & 0.32 & 1.04 & & 0.25 & 0.32 & 0.25 & \\
\hline $13 \mathrm{H}-7,16-17$ & 119.30 & 5.99 & 0.72 & 2.14 & 0.05 & & 1.42 & 2.14 & 1.42 & 0.05 \\
\hline $13 \mathrm{H}-7,16-17^{*}$ & 119.30 & 5.99 & 0.72 & 0.77 & 7.46 & & 0.05 & 2.21 & 1.50 & \\
\hline $14 \mathrm{H}-1,38-39$ & 120.18 & 27.04 & 3.24 & 9.81 & 0.36 & & 6.57 & 4.55 & 1.31 & \\
\hline $14 \mathrm{H}-2,38-39$ & 121.70 & 27.81 & 3.33 & 3.61 & 0.05 & & 0.28 & 2.64 & -0.70 & 0.05 \\
\hline $14 \mathrm{H}-3,38-39$ & 123.17 & 20.26 & 2.43 & 7.15 & 1.85 & 0.32 & 4.72 & 3.73 & 1.30 & \\
\hline $14 \mathrm{H}-3,38-39$ & 123.17 & 20.26 & 2.43 & 7.32 & 1.01 & & 4.89 & 3.78 & 1.35 & \\
\hline $14 \mathrm{H}-4,38-39$ & 124.64 & 14.69 & 1.76 & 4.91 & 2.21 & 0.28 & 3.15 & 3.04 & 1.28 & \\
\hline $14 \mathrm{H}-4,38-39$ & 124.64 & 14.69 & 1.76 & 5.15 & 0.98 & & 3.39 & 3.11 & 1.35 & \\
\hline $14 \mathrm{H}-5,38-39$ & 126.10 & 10.73 & 1.29 & 3.71 & 3.77 & 0.37 & 2.42 & 2.67 & 1.38 & \\
\hline $14 \mathrm{H}-5,38-39$ & 126.10 & 10.73 & 1.29 & 3.75 & 1.18 & & 2.46 & 2.68 & 1.39 & \\
\hline $14 \mathrm{H}-6,38-39$ & 127.56 & 3.48 & 0.42 & 1.25 & 0.07 & & 0.83 & 1.25 & 0.83 & 0.07 \\
\hline $14 \mathrm{H}-7,20-21^{*}$ & 128.84 & 15.45 & 1.85 & 5.16 & 0.05 & & 3.31 & 3.12 & 1.26 & 0.05 \\
\hline $14 \mathrm{H}-7,20-21$ & 128.84 & 15.45 & 1.85 & 1.92 & 3.17 & & 0.07 & 3.25 & 1.40 & \\
\hline $15 \mathrm{H}-1,38-39$ & 129.68 & 18.54 & 2.22 & 7.26 & 0.08 & & 5.04 & 3.77 & 1.54 & 0.08 \\
\hline $15 \mathrm{H}-2,38-39$ & 131.18 & 8.06 & 0.97 & 2.84 & 0.05 & & 1.87 & 2.40 & 1.43 & 0.05 \\
\hline $15 \mathrm{H}-3,38-39$ & 132.68 & 0.27 & 0.03 & 0.65 & 1.00 & & 0.62 & 0.65 & 0.62 & \\
\hline $15 \mathrm{H}-4,38-39$ & 134.18 & 0.59 & 0.07 & 0.48 & 0.05 & & 0.41 & 0.48 & 0.41 & 0.05 \\
\hline $15 \mathrm{H}-5,38-39$ & 135.68 & 17.85 & 2.14 & 6.49 & 0.05 & & 4.35 & 3.53 & 1.39 & 0.05 \\
\hline $15 \mathrm{H}-5,38-39$ & 135.68 & 18.10 & 2.17 & & & & & & & \\
\hline $15 \mathrm{H}-6,38-39$ & 137.18 & 0.26 & 0.03 & 0.29 & 0.04 & & 0.26 & 0.29 & 0.26 & 0.04 \\
\hline $15 \mathrm{H}-6,38-39$ & 137.18 & 0.20 & 0.02 & & & & & & & \\
\hline $16 \mathrm{H}-1,38-39$ & 139.18 & 12.24 & 1.47 & 12.24 & 0.04 & & 10.77 & 5.31 & 3.84 & 0.04 \\
\hline $16 \mathrm{H}-2,38-39$ & 140.63 & 35.70 & 4.28 & 12.32 & 0.05 & & 8.04 & 5.33 & 1.05 & 0.05 \\
\hline $16 \mathrm{H}-3,38-39$ & 142.08 & 51.29 & 6.15 & 17.61 & 1.76 & 0.37 & 11.46 & 6.97 & 0.82 & \\
\hline $16 \mathrm{H}-3,38-39$ & 142.08 & 51.29 & 6.15 & 18.26 & 0.69 & & 12.11 & 7.17 & 1.02 & \\
\hline $16 \mathrm{H}-4,38-39$ & 143.53 & 63.19 & 7.58 & 21.40 & 3.00 & & 13.82 & 8.14 & 0.56 & \\
\hline $16 \mathrm{H}-4,38-39$ & 143.53 & 63.19 & 7.58 & 21.87 & 0.04 & 0.00 & 14.29 & 8.28 & 0.71 & 0.04 \\
\hline $16 \mathrm{H}-4,38-39^{*}$ & 143.53 & 63.19 & 7.58 & 7.62 & 1.22 & & 0.04 & 8.39 & 0.81 & \\
\hline $16 \mathrm{H}-5,38-39$ & 144.98 & 44.96 & 5.39 & 15.04 & 2.41 & 0.32 & 9.65 & 6.17 & 0.78 & \\
\hline $16 \mathrm{H}-5,38-39$ & 144.98 & 44.96 & 5.39 & 15.90 & 0.81 & & 10.51 & 6.44 & 1.05 & \\
\hline $16 \mathrm{H}-6,38-39$ & 146.43 & 47.26 & 5.67 & 16.24 & 1.94 & 0.32 & 10.57 & 6.54 & 0.88 & \\
\hline $16 \mathrm{H}-6,38-39$ & 146.43 & 47.26 & 5.67 & 16.80 & 0.05 & & 11.13 & 6.72 & 1.05 & 0.05 \\
\hline $16 \mathrm{H}-6,38-39^{*}$ & 146.43 & 47.26 & 5.67 & 6.35 & 1.86 & & 0.68 & 7.24 & 1.58 & \\
\hline $18 \mathrm{X}-1,42-43$ & 148.42 & 43.38 & 5.20 & 15.78 & 0.05 & & 10.58 & 6.40 & 1.20 & 0.05 \\
\hline $19 X-2,9-10$ & 157.59 & 40.76 & 4.89 & 14.30 & 1.46 & & 9.41 & 5.94 & 1.05 & \\
\hline $19 X-2,40-41$ & 157.90 & 61.77 & 7.41 & 21.73 & 0.01 & 0.00 & 14.32 & 8.24 & 0.84 & 0.01 \\
\hline $19 \mathrm{X}-2,40-41^{*}$ & 157.90 & 61.77 & 7.41 & 7.53 & 1.37 & & 0.12 & 8.30 & 0.90 & \\
\hline $19 X-2,59-60$ & 158.09 & 2.62 & 0.31 & 1.01 & 0.05 & 0.00 & 0.70 & 1.01 & 0.70 & 0.05 \\
\hline 19X-2, 110-111 & 158.60 & 56.90 & 6.83 & 20.42 & 0.02 & 0.00 & 13.59 & 7.84 & 1.01 & 0.02 \\
\hline $19 X-3,20-21$ & 159.20 & 32.56 & 3.91 & 11.42 & 0.05 & & 7.51 & 5.05 & 1.14 & 0.05 \\
\hline $19 X-5,50-51$ & 162.50 & 24.50 & 2.94 & 8.79 & 0.54 & 0.00 & 5.85 & 4.24 & 1.30 & \\
\hline
\end{tabular}


Table T22 (continued). (Continued on next page.)

\begin{tabular}{|c|c|c|c|c|c|c|c|c|c|c|}
\hline $\begin{array}{l}\text { Core, section, } \\
\text { interval }(\mathrm{cm})\end{array}$ & $\begin{array}{l}\text { Depth } \\
\text { (mbsf) }\end{array}$ & $\begin{array}{l}\mathrm{CaCO}_{3} \\
\text { (wt\%) }\end{array}$ & $\begin{array}{c}\text { IC } \\
\text { (wt\%) }\end{array}$ & $\begin{array}{c}\text { TC } \\
(w t \%)\end{array}$ & $\begin{array}{c}\mathrm{TN} \\
\text { (wt\%) }\end{array}$ & $\begin{array}{c}\text { TS } \\
\text { (wt\%) }\end{array}$ & $\begin{array}{l}\text { TOC } \\
\text { (wt\%) }\end{array}$ & $\begin{array}{c}\text { Corrected } \\
\text { TC } \\
\text { (wt\%) }\end{array}$ & $\begin{array}{c}\text { Corrected } \\
\text { TOC } \\
\text { (wt\%) }\end{array}$ & $\begin{array}{c}\mathrm{TN}^{\dagger} \\
(\mathrm{wt} \%)\end{array}$ \\
\hline $19 X-5,74-75$ & 162.74 & 13.61 & 1.63 & 4.96 & 0.04 & 0.00 & 3.33 & 3.05 & 1.42 & 0.04 \\
\hline $19 X-6,13-14$ & 163.63 & 28.22 & 3.38 & 10.12 & 0.05 & & 6.74 & 4.65 & 1.27 & 0.05 \\
\hline $20 X-1,125-126$ & 166.95 & 24.63 & 2.96 & 8.76 & 0.02 & 0.00 & 5.80 & 4.23 & 1.27 & 0.02 \\
\hline $20 X-2,23-24$ & 167.43 & 32.03 & 3.84 & 11.10 & 0.05 & & 7.26 & 4.95 & 1.11 & 0.05 \\
\hline $20 \mathrm{X}-2,23-24^{\star}$ & 167.43 & 32.03 & 3.84 & 3.86 & 2.53 & & 0.02 & 5.00 & 1.16 & \\
\hline $20 X-3,52-53$ & 169.22 & 39.92 & 4.79 & 13.56 & 2.93 & 0.39 & 8.77 & 5.71 & 0.93 & \\
\hline $20 X-3,52-53^{*}$ & 169.22 & 39.92 & 4.79 & 4.93 & 2.41 & & 0.14 & 5.96 & 1.17 & \\
\hline 20X-4, 70-71 & 170.90 & 32.45 & 3.89 & 11.60 & 0.02 & 0.00 & 7.71 & 5.11 & 1.22 & 0.02 \\
\hline $20 X-5,73-74$ & 172.43 & 30.51 & 3.66 & 10.92 & 0.03 & 0.00 & 7.26 & 4.90 & 1.24 & 0.03 \\
\hline $20 X-5,73-74^{*}$ & 172.43 & 30.51 & 3.66 & 3.72 & 3.80 & & 0.06 & 4.87 & 1.21 & \\
\hline $20 X-6,55-56$ & 173.75 & 30.94 & 3.71 & 10.79 & 0.05 & & 7.08 & 4.86 & 1.15 & 0.05 \\
\hline $20 X-7,23-24$ & 174.83 & 30.12 & 3.62 & 11.13 & 0.05 & & 7.51 & 4.96 & 1.35 & 0.05 \\
\hline $21 X-1,74-75$ & 176.14 & 18.61 & 2.23 & 6.30 & 0.04 & 0.00 & 4.07 & 3.47 & 1.24 & 0.04 \\
\hline $21 X-2,28-29$ & 177.18 & 9.08 & 1.09 & 3.21 & 0.05 & 0.22 & 2.12 & 2.51 & 1.42 & 0.05 \\
\hline $21 X-2,47-48$ & 177.37 & 17.97 & 2.15 & 6.37 & 0.04 & 0.33 & 4.22 & 3.49 & 1.34 & 0.04 \\
\hline $21 X-2,52-53$ & 177.42 & 19.85 & 2.38 & 7.13 & 0.03 & 0.00 & 4.75 & 3.72 & 1.34 & 0.03 \\
\hline $21 X-2,57-58$ & 177.47 & 21.55 & 2.58 & 7.78 & 0.04 & 0.29 & 5.20 & 3.93 & 1.34 & 0.04 \\
\hline $21 X-2,77-78$ & 177.67 & 15.19 & 1.82 & 5.80 & 0.04 & 0.37 & 3.98 & 3.31 & 1.49 & 0.04 \\
\hline $21 X-2,98-99$ & 177.88 & 12.74 & 1.53 & 4.94 & 0.04 & 0.30 & 3.41 & 3.05 & 1.52 & 0.04 \\
\hline $21 X-2,117-118$ & 178.07 & 12.15 & 1.46 & 4.31 & 0.04 & 0.38 & 2.85 & 2.85 & 1.40 & 0.04 \\
\hline $21 X-2,137-137$ & 178.27 & 15.80 & 1.90 & 5.16 & 0.04 & 0.31 & 3.26 & 3.12 & 1.22 & 0.04 \\
\hline $21 X-3,8-9$ & 178.48 & 7.09 & 0.85 & 2.78 & 0.05 & 0.00 & 1.93 & 2.38 & 1.53 & 0.05 \\
\hline $21 X-3,29-30$ & 178.69 & 23.02 & 2.76 & 7.93 & 0.03 & 0.33 & 5.17 & 3.97 & 1.21 & 0.03 \\
\hline $21 X-3,48-49$ & 178.88 & 20.23 & 2.43 & 7.43 & 0.03 & 0.00 & 5.01 & 3.82 & 1.39 & 0.03 \\
\hline $21 X-3,49-50$ & 178.89 & 20.95 & 2.51 & 7.63 & 0.03 & 0.00 & 5.12 & 3.88 & 1.37 & 0.03 \\
\hline $21 X-3,68-69$ & 179.08 & & & 5.64 & 0.01 & 0.00 & & 3.26 & ND & 0.01 \\
\hline $21 X-3,89-90$ & 179.29 & 9.45 & 1.13 & 3.68 & 0.03 & 0.00 & 2.55 & 2.66 & 1.52 & 0.03 \\
\hline $21 X-3,108-109$ & 179.48 & & & 2.75 & 0.04 & 0.36 & & 2.37 & ND & 0.04 \\
\hline $21 X-3,129-130$ & 179.69 & 14.79 & 1.77 & 5.70 & 0.02 & 0.00 & 3.93 & 3.28 & 1.51 & 0.02 \\
\hline $21 X-3,149-150$ & 179.89 & 29.50 & 3.54 & 10.73 & 0.02 & 0.00 & 7.19 & 4.84 & 1.30 & 0.02 \\
\hline $21 X-3,149-150^{*}$ & 179.89 & 29.50 & 3.54 & 3.50 & 2.50 & & -0.04 & 4.67 & 1.14 & ND \\
\hline $21 X-4,3-4$ & 179.93 & 28.40 & 3.41 & 10.47 & 0.03 & 0.00 & 7.06 & 4.76 & 1.35 & 0.03 \\
\hline $21 X-4,18-19$ & 180.08 & 30.16 & 3.62 & 10.69 & 0.04 & 0.26 & 7.07 & 4.83 & 1.21 & 0.04 \\
\hline $21 X-4,38-39$ & 180.28 & 30.93 & 3.71 & 12.50 & 0.04 & 0.24 & 8.79 & 5.39 & 1.68 & 0.04 \\
\hline $21 X-4,58-59$ & 180.48 & 30.41 & 3.65 & 10.91 & 0.03 & 0.00 & 7.26 & 4.89 & 1.25 & 0.03 \\
\hline $21 X-4,58-59$ & 180.48 & 30.41 & 3.65 & 12.57 & 0.22 & 0.00 & 8.93 & 5.41 & 1.76 & ND \\
\hline $21 X-4,78-79$ & 180.68 & 24.07 & 2.89 & 8.62 & 0.03 & 0.28 & 5.73 & 4.19 & 1.30 & 0.03 \\
\hline 21X-4, 98-99 & 180.88 & 21.94 & 2.63 & 7.81 & 0.01 & 0.00 & 5.18 & 3.94 & 1.30 & 0.01 \\
\hline $21 X-4,118-119^{*}$ & 181.08 & 30.15 & 3.62 & 3.79 & 2.62 & & 0.18 & 4.93 & 1.32 & ND \\
\hline $21 X-4,118-119$ & 181.08 & 29.16 & 3.50 & 10.99 & 0.02 & 0.00 & 7.49 & 4.92 & 1.42 & 0.02 \\
\hline $21 X-4,138-139$ & 181.28 & 24.70 & 2.96 & 8.62 & 0.03 & 0.29 & 5.66 & 4.19 & 1.22 & 0.03 \\
\hline $21 X-5,8-9$ & 181.48 & 18.18 & 2.18 & 6.60 & 0.02 & 0.00 & 4.42 & 3.56 & 1.38 & 0.02 \\
\hline $21 X-5,30-31$ & 181.70 & 0.52 & 0.06 & 0.50 & 0.02 & 0.00 & 0.44 & 0.50 & 0.44 & 0.02 \\
\hline $21 X-5,50-51$ & 181.90 & 0.27 & 0.03 & 0.61 & 0.05 & 0.25 & 0.58 & 0.61 & 0.58 & 0.05 \\
\hline $21 X-5,61-62$ & 182.01 & 0.35 & 0.04 & 0.18 & 0.01 & 0.00 & 0.14 & 0.18 & 0.14 & 0.01 \\
\hline $21 X-5,61-62^{*}$ & 182.01 & 0.35 & 0.04 & 0.08 & 3.49 & 0.00 & 0.04 & 1.59 & 1.55 & \\
\hline $21 X-5,70-71$ & 182.10 & 0.24 & 0.03 & 0.07 & 0.03 & 0.29 & 0.04 & 0.07 & 0.04 & 0.03 \\
\hline $21 X-5,80-81$ & 182.20 & 0.40 & 0.05 & 0.15 & 0.03 & 0.36 & 0.10 & 0.15 & 0.10 & 0.03 \\
\hline $21 X-5,88-89$ & 182.28 & 0.30 & 0.04 & 0.16 & 0.03 & 0.31 & 0.12 & 0.16 & 0.12 & 0.03 \\
\hline $21 X-5,108-109$ & 182.48 & 0.30 & 0.04 & 0.17 & 0.03 & 0.36 & 0.13 & 0.17 & 0.13 & 0.03 \\
\hline $21 X-5,128-129$ & 182.68 & 0.16 & 0.02 & 0.30 & 0.04 & 0.30 & 0.28 & 0.30 & 0.28 & 0.04 \\
\hline $21 X-5,148-149$ & 182.88 & 0.28 & 0.03 & 0.35 & 0.05 & 0.00 & 0.32 & 0.35 & 0.32 & 0.05 \\
\hline $21 X-6,11-12$ & 183.01 & 0.32 & 0.04 & 0.33 & 0.04 & 0.00 & 0.29 & 0.33 & 0.29 & 0.04 \\
\hline $21 X-6,31-32$ & 183.21 & 0.21 & 0.03 & 0.36 & 0.04 & 0.00 & 0.33 & 0.36 & 0.34 & 0.04 \\
\hline $21 X-6,51-52$ & 183.41 & 0.32 & 0.04 & 0.29 & 0.05 & 0.00 & 0.25 & 0.29 & 0.25 & 0.05 \\
\hline $21 X-6,56-57$ & 183.46 & 0.41 & 0.05 & 0.29 & 0.02 & 0.00 & 0.24 & 0.29 & 0.24 & 0.02 \\
\hline $21 X-6,71-72$ & 183.61 & 0.46 & 0.06 & 0.39 & 0.04 & 0.32 & 0.33 & 0.39 & 0.33 & 0.04 \\
\hline $21 X-6,91-92$ & 183.81 & 0.17 & 0.02 & 0.51 & 0.05 & 0.22 & 0.49 & 0.51 & 0.49 & 0.05 \\
\hline $21 X-7,12-13$ & 184.02 & 0.37 & 0.05 & 0.64 & 0.03 & 0.29 & 0.60 & 0.64 & 0.60 & 0.03 \\
\hline $21 X-7,32-33$ & 184.22 & 0.22 & 0.03 & 0.56 & 0.03 & 0.31 & 0.53 & 0.56 & 0.53 & 0.03 \\
\hline $21 X-7,52-53$ & 184.42 & 0.89 & 0.11 & 0.68 & 0.03 & 0.30 & 0.57 & 0.68 & 0.57 & 0.03 \\
\hline $21 X-7,56-57$ & 184.46 & 1.06 & 0.13 & 0.59 & 0.01 & 0.00 & 0.46 & 0.59 & 0.46 & 0.01 \\
\hline $21 X-7,72-73$ & 184.62 & 0.16 & 0.02 & 0.60 & 0.05 & 0.23 & 0.58 & 0.60 & 0.58 & 0.05 \\
\hline $21 X-7,91-92$ & 184.81 & 0.21 & 0.03 & 0.72 & 0.05 & 0.39 & 0.70 & 0.72 & 0.70 & 0.05 \\
\hline $22 \mathrm{X}-1,40-41$ & 185.50 & 0.34 & 0.04 & 0.46 & 0.02 & 0.00 & 0.42 & 0.46 & 0.42 & 0.02 \\
\hline $22 \mathrm{X}-2,40-41$ & 187.00 & 0.05 & 0.01 & 0.64 & 0.02 & 0.00 & 0.63 & 0.64 & 0.63 & 0.02 \\
\hline $22 X-3,35-36$ & 187.95 & 2.68 & 0.32 & 0.60 & 0.03 & 0.00 & 0.28 & 0.60 & 0.28 & 0.03 \\
\hline $23 X-1,43-44$ & 195.23 & 0.33 & 0.04 & 0.23 & 0.03 & 0.00 & 0.19 & 0.23 & 0.19 & 0.03 \\
\hline
\end{tabular}


Table T22 (continued). (Continued on next page.)

\begin{tabular}{|c|c|c|c|c|c|c|c|c|c|c|}
\hline $\begin{array}{l}\text { Core, section, } \\
\text { interval }(\mathrm{cm})\end{array}$ & $\begin{array}{l}\text { Depth } \\
\text { (mbsf) }\end{array}$ & $\begin{array}{l}\mathrm{CaCO}_{3} \\
\text { (wt\%) }\end{array}$ & $\begin{array}{c}\text { IC } \\
\text { (wt\%) }\end{array}$ & $\begin{array}{c}\text { TC } \\
\text { (wt\%) }\end{array}$ & $\begin{array}{c}\text { TN } \\
(w t \%)\end{array}$ & $\begin{array}{c}\text { TS } \\
\text { (wt\%) }\end{array}$ & $\begin{array}{c}\text { TOC } \\
\text { (wt\%) }\end{array}$ & $\begin{array}{c}\text { Corrected } \\
\text { TC } \\
\text { (wt\%) }\end{array}$ & $\begin{array}{c}\text { Corrected } \\
\text { TOC } \\
\text { (wt\%) }\end{array}$ & $\begin{array}{c}\mathrm{TN}^{\dagger} \\
(\mathrm{wt} \%)\end{array}$ \\
\hline $23 X-2,45-46$ & 196.75 & 0.12 & 0.01 & 0.29 & 0.03 & 0.38 & 0.28 & 0.29 & 0.28 & 0.03 \\
\hline $23 X-3,40-41$ & 198.20 & 0.32 & 0.04 & 0.12 & 0.03 & 0.00 & 0.08 & 0.12 & 0.08 & 0.03 \\
\hline $23 X-3,40-41$ & 198.20 & 0.19 & 0.02 & & & & & & & \\
\hline $23 X-3,76-77$ & 198.56 & 0.42 & 0.05 & 0.18 & 0.03 & 0.40 & 0.13 & 0.18 & 0.13 & 0.03 \\
\hline $23 X-4,26-27$ & 199.46 & 0.62 & 0.07 & 0.26 & 0.03 & 0.38 & 0.19 & 0.26 & 0.19 & 0.03 \\
\hline $23 X-5,13-14$ & 200.73 & 0.56 & 0.07 & & & & & & & \\
\hline $23 X-6,46-47$ & 202.56 & 36.98 & 4.43 & 13.29 & 0.03 & 0.00 & 8.86 & 5.63 & 1.20 & 0.03 \\
\hline $23 X-7,42-43$ & 203.92 & 37.31 & 4.47 & 13.84 & 0.02 & 0.00 & 9.37 & 5.80 & 1.33 & 0.02 \\
\hline $23 X-7,42-43^{*}$ & 203.92 & 37.31 & 4.47 & 4.65 & 2.65 & & 0.18 & 5.71 & 1.24 & \\
\hline $25 X-1,93-94$ & 210.63 & 21.48 & 2.58 & 7.81 & 0.06 & & 5.23 & 3.94 & 1.36 & 0.06 \\
\hline $25 X-2,61-63$ & 211.81 & 25.77 & 3.09 & 9.26 & 0.05 & & 6.17 & 4.38 & 1.29 & 0.05 \\
\hline $25 X-3,115-116$ & 213.85 & 0.77 & 0.09 & 0.49 & 0.05 & 0.00 & 0.40 & 0.49 & 0.40 & 0.05 \\
\hline $25 X-3,115-116$ & 213.85 & 0.32 & 0.04 & 7.24 & 0.02 & 0.00 & 7.20 & 3.76 & 3.72 & 0.02 \\
\hline $25 X-4,72-73$ & 214.92 & 24.27 & 2.91 & 8.73 & 0.05 & & 5.82 & 4.22 & 1.31 & 0.05 \\
\hline $25 X-5,67-68$ & 216.37 & 20.43 & 2.45 & 7.31 & 0.05 & & 4.86 & 3.78 & 1.33 & 0.05 \\
\hline $25 X-6,10-11$ & 217.30 & 1.59 & 0.19 & 6.67 & 0.05 & & 6.48 & 3.58 & 3.39 & 0.05 \\
\hline $26 \mathrm{X}-1,107-108$ & 215.57 & 1.33 & 0.16 & 0.82 & 0.12 & 0.00 & 0.66 & 0.82 & 0.66 & 0.12 \\
\hline $26 \mathrm{X}-2,83-84$ & 216.83 & 41.92 & 5.03 & 15.42 & 0.04 & 0.00 & 10.39 & 6.29 & 1.26 & 0.04 \\
\hline $26 X-3,5-6$ & 217.55 & 52.24 & 6.26 & 22.32 & 0.10 & 0.00 & 16.06 & 8.42 & 2.16 & 0.10 \\
\hline $26 X-3,25-26$ & 217.75 & 68.77 & 8.25 & 27.99 & 0.07 & 0.00 & 19.74 & 10.18 & 1.93 & 0.07 \\
\hline $26 X-3,45-46$ & 217.95 & 45.14 & 5.41 & 17.61 & 0.06 & 0.00 & 12.20 & 6.97 & 1.55 & 0.06 \\
\hline $26 X-3,65-66$ & 218.15 & 56.71 & 6.80 & 21.76 & 0.05 & 0.00 & 14.96 & 8.25 & 1.45 & 0.05 \\
\hline $26 \mathrm{X}-3,81-82$ & 218.31 & 67.01 & 8.03 & 24.30 & 0.02 & 0.00 & 16.27 & 9.04 & 1.00 & 0.02 \\
\hline $26 X-3,85-86$ & 218.35 & 68.55 & 8.22 & 26.17 & 0.05 & 0.00 & 17.95 & 9.61 & 1.40 & 0.05 \\
\hline $26 \mathrm{X}-3,105-106$ & 218.55 & 68.27 & 8.19 & 27.50 & 0.05 & 0.00 & 19.31 & 10.03 & 1.84 & 0.05 \\
\hline $26 \mathrm{X}-3,125-126$ & 218.75 & 66.33 & 7.95 & 26.13 & 0.05 & 0.00 & 18.18 & 9.60 & 1.65 & 0.05 \\
\hline $26 X-3,145-146$ & 218.95 & 70.03 & 8.40 & 27.13 & 0.04 & 0.00 & 18.73 & 9.91 & 1.52 & 0.04 \\
\hline $26 X-4,5-6$ & 219.05 & 65.94 & 7.91 & 26.15 & 0.05 & 0.00 & 18.24 & 9.61 & 1.70 & 0.05 \\
\hline $26 X-4,25-26$ & 219.25 & 69.76 & 8.36 & 24.91 & 0.03 & 0.00 & 16.55 & 9.22 & 0.86 & 0.03 \\
\hline $26 X-4,41-42$ & 219.41 & 62.53 & 7.50 & 22.78 & 0.03 & 0.00 & 15.28 & 8.57 & 1.07 & 0.03 \\
\hline $26 X-4,44-45$ & 219.44 & 59.91 & 7.18 & 23.64 & 0.05 & 0.00 & 16.46 & 8.83 & 1.65 & 0.05 \\
\hline $26 X-4,65-66$ & 219.65 & 43.24 & 5.18 & 17.26 & 0.07 & 0.00 & 12.08 & 6.86 & 1.67 & 0.07 \\
\hline $26 X-4,85-86$ & 219.85 & 54.32 & 6.51 & 21.79 & 0.06 & 0.00 & 15.28 & 8.26 & 1.75 & 0.06 \\
\hline $26 X-4,105-106$ & 220.05 & 51.37 & 6.16 & 20.55 & 0.06 & 0.00 & 14.39 & 7.88 & 1.72 & 0.06 \\
\hline $26 \mathrm{X}-4,125-126$ & 220.25 & 55.94 & 6.71 & 22.13 & 0.05 & 0.00 & 15.42 & 8.36 & 1.66 & 0.05 \\
\hline $26 X-4,135-136$ & 220.35 & 62.26 & 7.46 & 24.76 & 0.06 & 0.00 & 17.30 & 9.18 & 1.71 & 0.06 \\
\hline $26 \mathrm{X}-4,145-146$ & 220.45 & 41.85 & 5.02 & 25.21 & 0.05 & 0.00 & 20.19 & 9.32 & 4.30 & 0.05 \\
\hline $26 X-5,5-6$ & 220.55 & 65.50 & 7.85 & 17.29 & 0.06 & 0.00 & 9.44 & 6.87 & ND & 0.06 \\
\hline $26 X-5,25-26$ & 220.75 & 66.71 & 8.00 & 25.96 & 0.03 & 0.00 & 17.96 & 9.55 & 1.55 & 0.03 \\
\hline $26 X-5,45-46$ & 220.95 & 52.02 & 6.24 & 19.96 & 0.04 & 0.00 & 13.72 & 7.69 & 1.46 & 0.04 \\
\hline $26 X-5,65-66$ & 221.15 & 54.16 & 6.49 & 20.46 & 0.04 & 0.00 & 13.97 & 7.85 & 1.36 & 0.04 \\
\hline $26 X-5,74-75$ & 221.24 & 51.46 & 6.17 & 18.67 & 0.05 & & 12.50 & 7.29 & 1.13 & 0.05 \\
\hline $26 X-5,74-75^{*}$ & 221.24 & 51.46 & 6.17 & 7.40 & 2.90 & & 1.23 & 8.19 & 2.02 & \\
\hline $26 X-5,85-86$ & 221.35 & 59.66 & 7.15 & 22.64 & 0.03 & 0.00 & 15.49 & 8.52 & 1.37 & 0.03 \\
\hline $26 X-5,105-106$ & 221.55 & 51.64 & 6.20 & 19.25 & 0.04 & 0.00 & 13.05 & 7.47 & 1.27 & 0.04 \\
\hline $26 X-5,115-116$ & 221.65 & 40.16 & 4.82 & 15.65 & 0.06 & 0.00 & 10.83 & 6.36 & 1.55 & 0.06 \\
\hline $26 X-5,135-136$ & 221.85 & 30.51 & 3.66 & 11.63 & 0.06 & 0.00 & 7.97 & 5.12 & 1.46 & 0.06 \\
\hline $26 X-6,10-11$ & 222.10 & 57.78 & 6.93 & 21.49 & 0.02 & 0.00 & 14.56 & 8.17 & 1.24 & 0.02 \\
\hline $26 X-7,26-27$ & 223.52 & 66.80 & 8.01 & 26.09 & 0.01 & 0.00 & 18.08 & 9.59 & 1.58 & 0.01 \\
\hline $27 X-1,22-23$ & 224.42 & 67.22 & 8.06 & 23.62 & 0.05 & & 15.56 & 8.83 & 0.77 & 0.05 \\
\hline $27 X-2,130-131$ & 227.00 & 74.73 & 8.96 & 26.34 & 0.01 & 0.00 & 17.38 & 9.67 & 0.71 & 0.01 \\
\hline $27 X-3,60-61$ & 227.80 & 76.07 & 9.12 & 27.64 & 0.01 & 0.00 & 18.52 & 10.07 & 0.95 & 0.01 \\
\hline $27 X-4,96-97$ & 229.66 & 70.23 & 8.42 & 24.95 & 0.00 & 0.00 & 16.53 & 9.24 & 0.82 & 0.00 \\
\hline $27 X-5,92-93$ & 231.12 & 69.39 & 8.32 & 24.66 & 0.02 & 0.00 & 16.34 & 9.15 & 0.83 & 0.02 \\
\hline $27 X-6,9-10$ & 231.79 & 63.02 & 7.56 & 26.82 & 0.01 & 0.00 & 19.26 & 9.82 & 2.26 & 0.01 \\
\hline $27 X-6,9-10^{*}$ & 231.79 & 63.02 & 7.56 & 8.97 & 1.47 & & 1.41 & 9.60 & 2.05 & \\
\hline $28 \mathrm{X}-1,110-111$ & 235.00 & 86.31 & 10.35 & 31.39 & 0.01 & 0.00 & 21.04 & 11.23 & 0.88 & 0.01 \\
\hline $28 X-1,110-111^{*}$ & 235.00 & 86.31 & 10.35 & 10.32 & 0.48 & & -0.03 & 10.82 & 0.47 & \\
\hline $28 \mathrm{X}-2,84-85$ & 236.24 & 83.39 & 10.00 & 29.55 & 0.01 & 0.00 & 19.55 & 10.66 & 0.66 & 0.01 \\
\hline $28 X-3,63-64$ & 237.53 & 77.24 & 9.26 & 27.32 & 0.01 & 0.00 & 18.06 & 9.97 & 0.71 & 0.01 \\
\hline $28 X-4,95-96$ & 239.35 & 79.01 & 9.47 & 28.41 & 0.00 & 0.00 & 18.94 & 10.31 & 0.83 & 0.00 \\
\hline $28 X-4,95-96$ & 239.35 & 79.01 & 9.47 & 32.20 & 0.57 & 0.00 & 22.73 & 11.48 & 2.01 & \\
\hline $28 X-5,93-94$ & 240.83 & 70.26 & 8.42 & 25.11 & 0.00 & 0.00 & 16.69 & 9.29 & 0.86 & 0.00 \\
\hline $28 X-6,13-14$ & 241.53 & 70.71 & 8.48 & 25.32 & 0.01 & 0.00 & 16.84 & 9.35 & 0.87 & 0.01 \\
\hline \multicolumn{11}{|l|}{ 342-U1403B- } \\
\hline $26 X-3,92-93$ & 201.12 & 17.69 & 2.12 & 6.75 & 0.05 & & 4.63 & 3.61 & 1.49 & 0.05 \\
\hline $26 X-3,100-101$ & 201.20 & 19.08 & 2.29 & 7.69 & 0.05 & & 5.40 & 3.90 & 1.61 & 0.05 \\
\hline $26 X-4,9-10$ & 201.79 & 4.60 & 0.55 & 2.25 & 0.06 & & 1.70 & 2.22 & 1.66 & 0.06 \\
\hline
\end{tabular}


Table T22 (continued).

\begin{tabular}{|c|c|c|c|c|c|c|c|c|c|c|}
\hline $\begin{array}{l}\text { Core, section, } \\
\text { interval }(\mathrm{cm})\end{array}$ & $\begin{array}{l}\text { Depth } \\
\text { (mbsf) }\end{array}$ & $\begin{array}{l}\mathrm{CaCO}_{3} \\
(\mathrm{wt} \%)\end{array}$ & $\begin{array}{c}\text { IC } \\
\text { (wt\%) }\end{array}$ & $\begin{array}{c}\text { TC } \\
\text { (wt\%) }\end{array}$ & $\begin{array}{c}\text { TN } \\
\text { (wt\%) }\end{array}$ & $\begin{array}{c}\text { TS } \\
\text { (wt\%) }\end{array}$ & $\begin{array}{l}\text { TOC } \\
\text { (wt\%) }\end{array}$ & $\begin{array}{c}\text { Corrected } \\
\text { TC } \\
(w t \%)\end{array}$ & $\begin{array}{c}\text { Corrected } \\
\text { TOC } \\
\text { (wt\%) }\end{array}$ & $\begin{array}{c}\mathrm{TN}^{\dagger} \\
\text { (wt\%) }\end{array}$ \\
\hline $26 \mathrm{X}-4,17-18$ & 201.87 & 15.64 & 1.88 & 6.17 & 0.05 & & 4.29 & 3.43 & 1.55 & 0.05 \\
\hline $26 X-4,66-67$ & 202.36 & & & 3.95 & 0.05 & & 3.95 & 2.74 & & 0.05 \\
\hline $26 \mathrm{X}-4,85-86$ & 202.55 & 11.60 & 1.39 & 6.48 & 0.05 & & 5.09 & 3.52 & 2.13 & 0.05 \\
\hline
\end{tabular}

* = duplicate runs with high-carbonate La Luna shale calibration. $\dagger=$ uncorrected total nitrogen (TN) with anomalous values removed. For total sulfur (TS), zero sulfur values from runs without sulfur calibration were removed. For corrected total carbon (TC) with low-carbonate estuarine sediment calibration, if TC $<2.2 \mathrm{wt} \%$, no correction was applied; if TC $>2.2 \mathrm{wt} \%$, corrected TC $=2.2+(x-2.2) \times 0.309$. For corrected TC with high-carbonate La Luna shale calibration, if TC $<2.2 / 2.913$, corrected TC $=2.913 \times x$; if TC $>2.2 / 2.913$, corrected TC $=2.2+(x-2.2 / 2.913) \times$ 0.901 . Corrected total organic carbon (TOC) is corrected TC minus inorganic carbon (IC). ND = not detected. 
Table T23. Core top and composite depths, Site U1403.

\begin{tabular}{|c|c|c|c|c|c|}
\hline \multirow[b]{2}{*}{ Core } & \multicolumn{2}{|c|}{ Depth } & \multirow[b]{2}{*}{ Offset (m) } & \multirow{2}{*}{$\begin{array}{l}\text { Cumulative } \\
\text { offset }(m)\end{array}$} & \multirow[b]{2}{*}{ Comment } \\
\hline & (mbsf) & (m CCSF) & & & \\
\hline \multicolumn{6}{|c|}{ 342-U1403A- } \\
\hline $1 \mathrm{H}$ & 0.00 & -0.83 & -0.83 & -0.83 & \\
\hline $2 \mathrm{H}$ & 5.80 & 4.17 & -0.80 & -1.63 & \\
\hline $3 \mathrm{H}$ & 15.30 & 13.42 & -0.25 & -1.88 & \\
\hline $4 \mathrm{H}$ & 24.80 & 24.67 & 1.75 & -0.13 & \\
\hline $5 \mathrm{H}$ & 34.30 & 35.02 & 0.85 & 0.72 & Tentative \\
\hline $6 \mathrm{H}$ & 43.80 & 45.33 & 0.81 & 1.53 & \\
\hline $7 \mathrm{H}$ & 53.30 & 55.08 & 0.25 & 1.78 & \\
\hline $8 \mathrm{H}$ & 62.80 & 66.56 & 1.98 & 3.76 & \\
\hline $9 \mathrm{H}$ & 72.30 & 76.18 & 0.12 & 3.88 & \\
\hline $10 \mathrm{H}$ & 81.80 & 85.76 & 0.08 & 3.96 & \\
\hline $11 \mathrm{H}$ & 91.30 & 96.26 & 1.00 & 4.96 & \\
\hline $12 \mathrm{H}$ & 100.80 & 109.46 & 3.70 & 8.66 & Tentative \\
\hline $13 \mathrm{H}$ & 110.30 & 120.82 & 1.86 & 10.52 & \\
\hline $14 \mathrm{H}$ & 119.80 & 131.12 & 0.80 & 11.32 & \\
\hline $15 \mathrm{H}$ & 129.30 & 140.72 & 0.10 & 11.42 & \\
\hline $16 \mathrm{H}$ & 138.80 & 151.76 & 1.54 & 12.96 & \\
\hline $17 \mathrm{H}$ & 147.80 & 161.66 & 0.90 & 13.86 & Offset $=10 \%$ of drilling advance \\
\hline $18 \mathrm{X}$ & 148.00 & 161.88 & 0.02 & 13.88 & Offset $=10 \%$ of drilling advance \\
\hline $19 \mathrm{X}$ & 156.00 & 173.08 & 3.20 & 17.08 & \\
\hline $20 x$ & 165.70 & 183.75 & 0.97 & 18.05 & Offset $=10 \%$ of drilling advance \\
\hline $21 \mathrm{x}$ & 175.40 & 194.42 & 0.97 & 19.02 & Offset $=10 \%$ of drilling advance \\
\hline $22 \mathrm{X}$ & 185.10 & 209.98 & 5.86 & 24.88 & Tied to Core U1403B-24X \\
\hline $23 x$ & 194.80 & 216.33 & -3.35 & 21.53 & Correct for offset Core U1403A-22X \\
\hline $24 \mathrm{X}$ & 204.50 & 227.00 & 0.97 & 22.50 & Offset $=10 \%$ of drilling advance \\
\hline $25 \mathrm{X}$ & 209.70 & 232.72 & 0.52 & 23.02 & Offset $=10 \%$ of drilling advance \\
\hline $26 \mathrm{X}$ & 214.50 & 241.58 & 4.06 & 27.08 & Offset in order to remove overlap between Cores $25 \mathrm{X}$ and $26 \mathrm{X}$ \\
\hline $27 x$ & 224.20 & 251.89 & 0.61 & 27.69 & \\
\hline $28 \mathrm{X}$ & 233.90 & 262.69 & 1.10 & 28.79 & \\
\hline \multicolumn{6}{|c|}{ 342-U1403B- } \\
\hline $1 \mathrm{H}$ & 0.00 & 0.00 & 0.00 & 0.00 & \\
\hline $2 \mathrm{H}$ & 3.90 & 3.55 & -0.35 & -0.35 & \\
\hline $3 \mathrm{H}$ & 13.40 & 11.20 & -1.85 & -2.20 & \\
\hline $4 \mathrm{H}$ & 18.90 & 21.85 & 5.15 & 2.95 & \\
\hline $5 \mathrm{H}$ & 28.40 & 32.25 & 0.90 & 3.85 & Tentative \\
\hline $6 \mathrm{H}$ & 34.90 & 41.10 & 2.35 & 6.20 & \\
\hline $7 \mathrm{H}$ & 44.40 & 52.00 & 1.40 & 7.60 & Tentative \\
\hline $8 \mathrm{H}$ & 53.90 & 62.28 & 0.78 & 8.38 & \\
\hline $9 \mathrm{H}$ & 63.40 & 72.08 & 0.30 & 8.68 & Tentative \\
\hline $10 \mathrm{H}$ & 72.90 & 81.86 & 0.28 & 8.96 & \\
\hline $11 \mathrm{H}$ & 82.40 & 91.99 & 0.63 & 9.59 & \\
\hline $12 \mathrm{H}$ & 91.90 & 102.43 & 0.94 & 10.53 & \\
\hline $13 \mathrm{H}$ & 101.40 & 113.03 & 1.10 & 11.63 & \\
\hline $14 \mathrm{H}$ & 110.90 & 124.65 & 2.12 & 13.75 & \\
\hline $15 \mathrm{H}$ & 120.40 & 136.15 & 2.00 & 15.75 & \\
\hline $16 \mathrm{H}$ & 129.90 & 146.33 & 0.68 & 16.43 & \\
\hline $17 X$ & 138.30 & 160.73 & 6.00 & 22.43 & Cored through chert interval \\
\hline $18 \mathrm{X}$ & 145.40 & 163.38 & -4.45 & 17.98 & Cored through chert interval \\
\hline $19 \mathrm{H}$ & 150.40 & 168.88 & 0.50 & 18.48 & Offset $=10 \%$ of drilling advance \\
\hline $20 \mathrm{H}$ & 155.00 & 172.87 & -0.61 & 17.87 & \\
\hline $21 \mathrm{H}$ & 164.00 & 184.85 & 2.98 & 20.85 & \\
\hline $22 \mathrm{H}$ & 173.00 & 196.54 & 2.69 & 23.54 & \\
\hline $23 x$ & 175.90 & 200.56 & 1.12 & 24.66 & \\
\hline $24 X$ & 184.50 & 210.02 & 0.86 & 25.52 & Offset $=10 \%$ of drilling advance \\
\hline $25 x$ & 187.50 & 211.59 & -1.43 & 24.09 & \\
\hline $26 \mathrm{X}$ & 197.20 & 222.65 & 1.36 & 25.45 & \\
\hline $27 x$ & 206.90 & 233.32 & 0.97 & 26.42 & Offset $=10 \%$ of drilling advance \\
\hline $28 \mathrm{X}$ & 216.60 & 247.00 & 3.98 & 30.40 & \\
\hline $29 \mathrm{X}$ & 226.30 & 258.72 & 2.02 & 32.42 & \\
\hline $30 x$ & 236.00 & 268.89 & 0.47 & 32.89 & \\
\hline $31 \mathrm{x}$ & 245.70 & 279.56 & 0.97 & 33.86 & Offset $=10 \%$ of drilling advance \\
\hline $32 x$ & 255.40 & 290.23 & 0.97 & 34.83 & Offset $=10 \%$ of drilling advance \\
\hline
\end{tabular}


Table T24. Splice tie points, Site U1403.

\begin{tabular}{|c|c|c|c|c|c|c|c|}
\hline \multirow{2}{*}{$\begin{array}{l}\text { Hole, core, section, } \\
\text { interval }(\mathrm{cm})\end{array}$} & \multicolumn{2}{|c|}{ Depth } & & \multirow{2}{*}{$\begin{array}{l}\text { Hole, core, section, } \\
\text { interval }(\mathrm{cm})\end{array}$} & \multicolumn{2}{|c|}{ Depth } & \multirow[b]{2}{*}{ Comment } \\
\hline & (mbsf) & (m CCSF) & & & (mbsf) & (m CCSF) & \\
\hline \multirow[t]{2}{*}{$342-$} & & & & $342-$ & & & \\
\hline & & & & U1403B-1H-1, 0 & 0.00 & 0.00 & \\
\hline U1403B-1H-2, 115 & 2.65 & 2.65 & Tie to & U1403A-1H-3, 47.7 & 3.48 & 2.65 & \\
\hline U1403A-1H-4, 46.3 & 4.96 & 4.13 & Tie to & U1403B-2H-1, 57.5 & 4.48 & 4.13 & \\
\hline U1403B-2H-6, 137.5 & 12.78 & 12.43 & Tie to & U1403B-3H-1, 122.5 & 14.63 & 12.43 & \\
\hline U1403B-3H-5, 135 & 20.75 & 18.55 & Tie to & U1403A-3H-4, 63.3 & 20.43 & 18.55 & \\
\hline U1403A-3H-7, 27.5 & 24.58 & 22.70 & Tie to & U1403B-4H-1, 85 & 19.75 & 22.70 & \\
\hline U1403B-4H-4, 5.3 & 23.45 & 26.40 & Tie to & U1403A-4H-2, 22.5 & 26.53 & 26.40 & \\
\hline U1403A-4H-7, 10.7 & 33.61 & 33.48 & Tie to & U1403B-5H-1, 122.5 & 29.63 & 33.48 & Small overlap \\
\hline U1403B-5H-4, 10 & 33.00 & 36.85 & Tie to & U1403A-5H-2, 32.5 & 36.13 & 36.85 & Tentative \\
\hline U1403A-5H-6, 87.5 & 42.68 & 43.40 & Tie to & U1403B-6H-2, 80 & 37.20 & 43.40 & \\
\hline U1403B-6H-5, 87.5 & 41.38 & 47.58 & Tie to & U1403A-6H-2, 75 & 46.05 & 47.58 & \\
\hline U1403A-6H-6, 93.9 & 52.32 & 53.85 & Tie to & U1403B-7H-2, 35 & 46.25 & 53.85 & Tentative \\
\hline U1403B-7H-6, 82.5 & 52.73 & 60.33 & Tie to & U1403A-7H-4, 75.4 & 58.55 & 60.33 & \\
\hline U1403A-7H-6, 72.5 & 61.53 & 63.31 & Tie to & U1403B-8H-1, 102.5 & 54.93 & 63.31 & \\
\hline U1403B-8H-5, 133.2 & 61.23 & 69.61 & Tie to & U1403A-8H-3, 5 & 65.85 & 69.61 & \\
\hline U1403A-8H-5, 89.1 & 69.72 & 73.48 & Tie to & U1403B-9H-1, 140 & 64.80 & 73.48 & Tentative \\
\hline U1403B-9H-5, 48.2 & 69.88 & 78.56 & Tie to & U1403A-9H-2, 87.5 & 74.68 & 78.56 & \\
\hline U1403A-9H-5, 144.2 & 79.68 & 83.56 & Tie to & U1403B-10H-2, 25 & 74.60 & 83.56 & \\
\hline U1403B-10H-5, 100.8 & 79.76 & 88.72 & Tie to & U1403A-10H-2, 145 & 84.76 & 88.72 & \\
\hline U1403A-10H-6, 80 & 90.01 & 93.97 & Tie to & U1403B-11H-2, 47.7 & 84.38 & 93.97 & \\
\hline U1403B-11H-6, 47.5 & 90.40 & 99.99 & Tie to & U1403A-11H-3, 72.5 & 95.03 & 99.99 & \\
\hline U1403A-11H-6, 85 & 99.65 & 104.61 & Tie to & U1403B-12H-2, 67.5 & 94.08 & 104.61 & \\
\hline U1403B-12H-6, 115.7 & 100.41 & 110.94 & Tie to & U1403A-12H-1, 147.5 & 102.28 & 110.94 & Small overlap \\
\hline U1403A-12H-7, 5 & 109.87 & 118.53 & Tie to & U1403B-13H-4, 98.6 & 106.90 & 118.53 & \\
\hline U1403B-13H-7, 17.5 & 110.17 & 121.80 & Tie to & U1403A-13H-1, 97.5 & 111.28 & 121.80 & \\
\hline U1403A-13H-5, 65 & 116.86 & 127.38 & Tie to & U1403B-14H-2, 122.5 & 113.63 & 127.38 & \\
\hline U1403B-14H-6, 10 & 118.50 & 132.25 & Tie to & U1403A-14H-1, 112.5 & 120.93 & 132.25 & \\
\hline U1403A-14H-6, 32.5 & 127.51 & 138.83 & Tie to & U1403B-15H-2, 117.5 & 123.08 & 138.83 & \\
\hline U1403B-15H-6, 40 & 128.30 & 144.05 & Tie to & U1403A-15H-3, 32.5 & 132.63 & 144.05 & \\
\hline U1403A-15H-5, 117.5 & 136.48 & 147.90 & Tie to & U1403B-16H-2, 7.4 & 131.47 & 147.90 & \\
\hline U1403B-16H-5, 110.8 & 137.01 & 153.44 & Tie to & U1403A-16H-2, 22.5 & 140.48 & 153.44 & \\
\hline U1403A-16H-6, 147.5 & 147.53 & 160.49 & Append to & U1403B-19H-1, 5 & 150.45 & 168.93 & Tentative tie between two cores in Hole U1403B \\
\hline U1403B-19H-4, 40.8 & 154.74 & 173.22 & Tie to & U1403B-20H-1, 35 & 155.35 & 173.22 & \\
\hline U1403B-20H-5, 12.5 & 161.14 & 179.01 & Tie to & U1403A-19X-4, 143 & 161.93 & 179.01 & \\
\hline U1403A-19X-7, 65 & 165.45 & 182.53 & Append to & U1403A-20X-1, 3 & 165.73 & 183.78 & \\
\hline U1403A-20X-2, 80 & 168.00 & 186.05 & Tie to & U1403B-21H-1, 120 & 165.20 & 186.05 & \\
\hline U1403B-21H-7, 20 & 172.70 & 193.55 & Append to & U1403A-21X-1, 3 & 175.43 & 194.45 & \\
\hline U1403A-21X-7, 90 & 184.80 & 203.82 & Append to & U1403A-22X-1, 3 & 185.13 & 210.01 & \\
\hline U1403A-22X-2, 64.4 & 187.24 & 212.12 & Tie to & U1403B-25X-1, 52.5 & 188.03 & 212.12 & \\
\hline U1403B-25X-5, 133.5 & 194.84 & 218.93 & Tie to & U1403A-23X-2, 110.1 & 197.40 & 218.93 & \\
\hline U1403A23-X-6, 114.7 & 203.25 & 224.78 & Tie to & U1403B-26X-2, 62.5 & 199.33 & 224.78 & \\
\hline U1403B-26X-4, 150.2 & 203.20 & 228.65 & Append to & U1403A-25X-1, 22.5 & 209.93 & 232.95 & \\
\hline U1403A-25X-6, 62.4 & 217.82 & 240.84 & Append to & U1403A-26X-1, 2.5 & 214.53 & 241.61 & \\
\hline U1403A-26X-5, 94 & 221.44 & 248.52 & Tie to & U1403B-28X-2, 1.7 & 218.12 & 248.52 & \\
\hline U1403B-28X-5, 53 & 223.13 & 253.53 & Tie to & U1403A-27X-2, 14 & 225.84 & 253.53 & \\
\hline U1403A-27X-6, 23.5 & 231.94 & 259.63 & Tie to & U1403B-29X-1, 91 & 227.21 & 259.63 & \\
\hline U1403B-29X-5, 66 & 232.96 & 265.38 & Tie to & U1403A-28X-2, 119.4 & 236.59 & 265.38 & \\
\hline U1403A-28X-5, 109.3 & 240.99 & 269.78 & Tie to & U1403B-30X-1, 89 & 236.89 & 269.78 & \\
\hline U1403B-30X-4, 90 & 241.40 & 274.29 & Append to & U1403B-31X-1, 2.5 & 245.73 & 279.59 & \\
\hline U1403B-31X-CC, 46.3 & 251.87 & 285.73 & Append to & U1403B-32X-1, 2.5 & 255.43 & 290.26 & \\
\hline U1403B-32X-5, 63.6 & 261.74 & 296.57 & & & & & \\
\hline
\end{tabular}

